A History of the

Psychology Sehools at

Adelaide's

Universities

Edited by

Tony Winefield

Ted Nettelbeck

Welcome to the electronic edition of $A$ History of the Psychology Schools at Adelaide's Universities.

The book opens with the bookmark panel and you will see the contents page. Click on this anytime to return to the contents. You can also add your own bookmarks.

Each chapter heading in the contents table is clickable and will take you direct to the chapter. Return using the contents link in the bookmarks.

The whole document is fully searchable.

Enjoy.

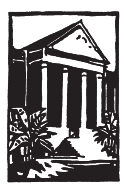

BARR SMITH PRESS

An imprint of 


$$
\begin{gathered}
\text { A History of the } \\
\text { Psychology Schools at } \\
\text { Adelaide's } \\
\text { Universities }
\end{gathered}
$$
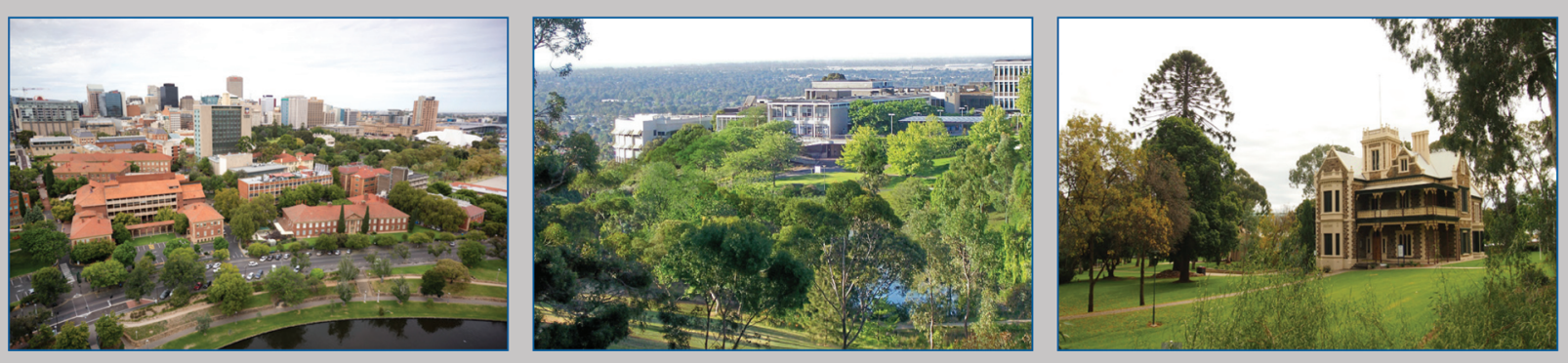

\author{
Edited by \\ Tony Winefield \\ and \\ Ted Nettelbeck
}




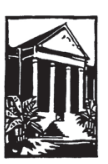

BARR SMITH PRESS

An imprint of

The University of Adelaide Press

\section{A History of the Psychology \\ Schools at Adelaide's Universities}

\section{Edited by Tony Winefield and Ted Nettelbeck}

This book commemorates the history of the psychology schools at Adelaide's three Universities: The University of Adelaide, Flinders University and the University of South Australia. Its publication in 2016 coincides with their $60^{\text {th }}, 50^{\text {th }}$ and $25^{\text {th }}$ birthdays respectively. Their core activities comprise undergraduate teaching, postgraduate research training, research and postgraduate professional training.

Commemorative activities, including this book, provide a link between our present day and the past, and help to explain the evolution of our institutions. They provide an opportunity to reflect on the achievements of each academic institution, and of the individuals within them.

Psychology at Adelaide's Universities has occupied a distinctive position within the state, and the documentation of its unique history is an important step in its official chronicle.
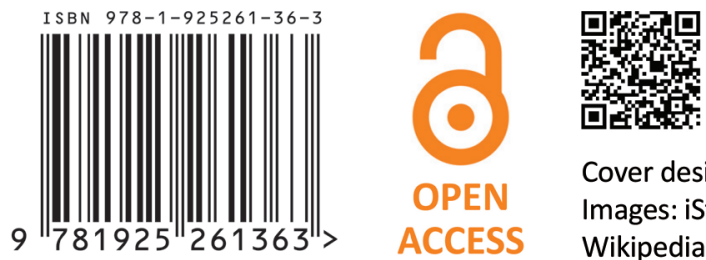

This book is available as a free ebook from adelaide.edu.au/press 


\section{A History of the Psychology Schools at Adelaide's Universities}




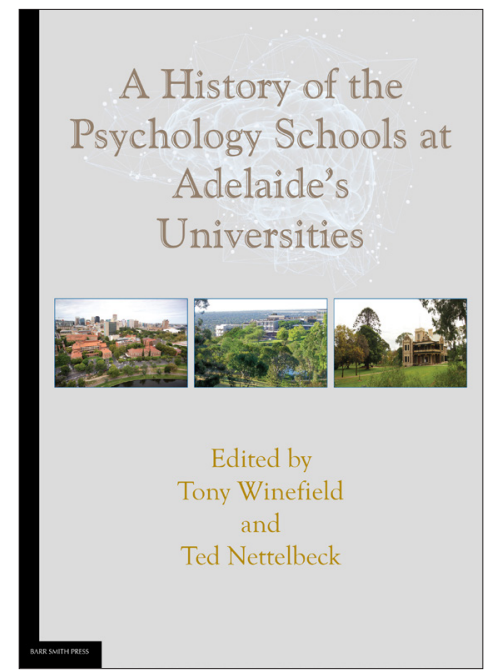

The high-quality paperback edition of this book is available for purchase online:

https://shop.adelaide.edu.au/ 


\section{A History of the \\ Psychology Schools at \\ Adelaide's Universities}

Edited by

Tony Winefield and Ted Nettelbeck

BARR SMITH PRESS

An imprint of

The University of Adelaide Press 
Published in Adelaide by

University of Adelaide Press

Barr Smith Library

The University of Adelaide

South Australia 5005

press@adelaide.edu.au

www.adelaide.edu.au/press

The Barr Smith Press is an imprint of the University of Adelaide Press, under which titles about the history of the University are published. The University of Adelaide Press publishes peer reviewed scholarly books. It aims to maximise access to the best research by publishing works through the internet as free downloads and for sale as high quality printed volumes.

\section{(C) 2016 The Contributors}

This work is licenced under the Creative Commons Attribution-NonCommercial-

NoDerivatives 4.0 International (CC BY-NC-ND 4.0) License. To view a copy of this licence, visit http://creativecommons.org/licenses/by-nc-nd/4.0 or send a letter to Creative Commons, 444 Castro Street, Suite 900, Mountain View, California, 94041, USA. This licence allows for the copying, distribution, display and performance of this work for non-commercial purposes providing the work is clearly attributed to the copyright holders. Address all inquiries to the Director at the above address.

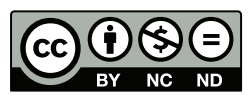

For the full Cataloguing-in-Publication data please contact the National Library of Australia: cip@nla.gov.au

ISBN (paperback) 978-1-925261-36-3

ISBN (ebook: pdf) 978-1-925261-37-0

ISBN (ebook: epub) 978-1-925261-38-7

ISBN (ebook: kindle) 978-1-925261-39-4

DOI: http://dx.doi.org/10.20851/history-psychology

Book design: Zoë Stokes

Cover design: John Emerson

Cover images: iStockphoto (brain transparency), Wikipedia (photographs)

Paperback printed by Griffin Press, South Australia 


\section{Contents}

List of contributors vii

Preface $\quad x i$

Tony Winefield

1 Introduction 1

Tony Winefield

2 The origins and early history of the University 11 of Adelaide's School of Psychology

Malcolm Jeeves and Tony Winefield

3 The later years 43

Anna Chur-Hansen

4 Teaching applied psychology at the University 77 of Adelaide: A personal view

Neil Kirby

5 Flinders University: Psychology in the 125 twentieth century

Leon Lack

6 Recent history of Flinders School of Psychology

Tracey Wade

7 The history of Psychology at the University of South Australia: From little things big things grow Jacques Metzer

8 The history of Psychology at the University of South Australia: Recent history Kurt Lushington 



\section{List of contributors}

We are most grateful for the contributions to the book made by our co-authors. Each has provided a brief autobiographical sketch, which we reproduce alphabetically below.

Anna Chur-Hansen was born in Adelaide in 1963. After matriculating from Findon High School, she commenced a Bachelor of Arts with honours in psychology at the University of Adelaide, 1981-84. Her PhD, in medical education, was completed in the Department of Psychiatry, University of Adelaide, where she served as an academic member of staff from 1987 to 2013, including periods as acting head. She is a registered psychologist, and holds an endorsement in health psychology. She returned to psychology at the University of Adelaide in late 2013 to become head of school.

Norman T Feather is emeritus professor of psychology at Flinders University. He is a graduate of the University of Sydney, the University of New England and the University of Michigan, where he received the Donald G Marquis Award for his doctoral dissertation. He is a past president and honorary fellow of theAustralian Psychological Society and recipient of their Distinguished Scientific Contribution Award. He is a fellow of the Academy of the Social Sciences in Australia, and a recipient of honorary degrees from the University of New England and Flinders University. He is also the recipient of the Turner Medal from the Society of Australasian Social Psychologists. He has published widely in the areas of achievement motivation; expectancy-value theory; attribution theory; gender roles and stereotypes; the psychology of values; social attitudes; the psychological impact of unemployment, deservingness, entitlement and justice-related behaviour; and emotions. He has authored or edited six books.

Malcolm A Jeeves completed military service from 1945 to 1948, after which he went up to Cambridge to read natural sciences and experimental psychology, remaining there to continue his research under Sir Frederic Bartlett FRS. He spent a year working with Professor Jerome Bruner at Harvard in 1953-54. In 1959, he was appointed to the foundation chair of psychology at the University of Adelaide, where he remained for ten years, before taking up his current position as foundation professor of psychology at the University of St Andrews. He is a past president of the Royal Society of Edinburgh, Scotland's National Academy, a fellow of the Academy of Medical Sciences, fellow of the British Psychological Society and a former fellow of the Australian Psychological 
Society. He was made a Commander of the British Empire [CBE] in 1991 for services to science and to psychology in Britain. A past editor-in-chief of Neuropsychologia, he has authored, co-authored or edited eighteen books and many scientific papers.

Neil Kirby is a senior lecturer and director of the Wellbeing Research Unit in the School of Psychology at the University of Adelaide. His research interests are in disability and organisational psychology. He was appointed a tutor in the then Department of Psychology in 1970. In 1974 he became the Bedford Industries research fellow, a large multidiagnostic rehabilitation centre in Adelaide. He became a full-time lecturer in 1992. He has taught applied psychology in the Diploma of Applied Psychology and in the Master of Psychology (Clinical) Course which replaced the Diploma, and he currently teaches primarily in the Master of Psychology (Organisational and Human Factors).

Leon Lack received his first degree from Stanford University in the US and his $\mathrm{PhD}$ from the University of Adelaide. Since 1971, he has been at Flinders University in the School of Psychology, teaching and conducting research in the areas of sleep, circadian rhythms, bright light therapy and insomnia. He has received many large research grants, published over 100 refereed articles, books and book chapters, and given over 200 conference papers in the sleep area. Since 1992, he has also directed the non-drug treatment program for insomnia at the Adelaide Institute for Sleep Health, Repatriation General Hospital. Professor Lack has also taken an active role in public education about sleep and the body clock through invited lectures, workshops, media presentations, and the publication of a popular book on the treatment of insomnia. He has patents for, and is co-inventor of, a portable bright light therapy device, Re-timer.com, used for the treatment of a mistimed body clock.

Kurt Lushington joined the School of Psychology at the University of South Australia as lecturer 1996. He completed his Master of Psychology (Clinical) and PhD at Flinders University of South Australia in 1998. His thesis work and subsequent research has explored extensively all aspects to do with sleep and its disorders. He is the current chair of the Australasian Sleep Association sub-committee for Behavioural Management of Sleep Disorders. He is a fellow of the Australian Psychological Society and a practising clinical psychologist. His current research outputs include eighty-eight peer-reviewed publications and fourteen book chapters. He has been a principle investigator on Category One grant funding (OLT, NHMRC and ARC), and a principle/associate supervisor of seventeen $\mathrm{PhD}$ students and eight doctorate of counselling/psychology students. He has taught psychology both at the undergraduate and postgraduate level and offshore in Singapore and Hong Kong. He is the current head of school for the School of Psychology, Social Work and Social Policy at the University of South Australia. 
Jacques Metzer completed a Bachelor of Science (Honours) and a PhD in the effects of social facilitation during operant conditioning of humans and laboratory rats at the University of Adelaide. He was appointed lecturer in 1977, then senior lecturer in 1984 at the then South Australian Institute of Technology. He served as the founding head of the School of Psychology at the University of South Australia from 1994 to 2005 and as associate professor from 2001 till 2009. Currently (2016), he is adjunct professor of clinical psychology at the University of Technology Sydney. Having registered to practise in 1977, he continues his registration nationally, maintaining an active role in psychology practice since 1983. With colleagues he has attracted approximately $\$ 1$ million in research grants and has produced fifty-five publications, eighty conference papers and thirty-four other reports. He is a member of the Working Committee of the Australian Psychology Accreditation Council and a fellow of the Australian Psychological Society, having served for many years as its chair and secretary of the South Australia State Branch and since 2012 on its national Ethics Committee. His interests over the years have ranged from animal behaviour to professional areas of applied psychology and currently in professional ethics and in stress and wellbeing at work.

Ted Nettelbeck was something of a late starter to psychology. Initially trained and employed for some years as a musician, he completed his honours degree in 1969 before becoming a full-time tutor while completing a $\mathrm{PhD}$. Subsequent appointments followed to research fellow (1972), lecturer (1974), senior lecturer (1978), reader (1985, later rebadged associate professor) and professor (2002). His research interests have encompassed human intelligence, intellectual disability and cognitive changes across the lifespan. Nettelbeck's work with an inspection time measure attracted wide international interest, establishing it as a primary tool for investigating the bases of intelligence and as a focus of interest worldwide. During a career encompassing forty-four years, Nettelbeck's research activities attracted considerable competitive funding support and generated more than 200 publications. Awards have included a Guest Research Fellowship by the Royal Society, UK (1990), Visiting Senior Scientist MRC Award, UK (1992), recognition as a world leader in the field of intellectual disability research (2000) and recognition as a Distinguished Contributor to the Field of Intelligence Research by the International Society for Intelligence Research (2008). He retired in late 2014 but, as emeritus professor, continues to contribute to the teaching and research activities of the school.

Tracey Wade was awarded the Ian M Campbell Memorial Prize for outstanding contribution to the scientific or professional status of clinical psychology in Australia in 2000, and in 2003 she was awarded the Australian Psychological Society Early Career Award. She has worked as a clinician in the area of eating disorders for over twenty years. She is on the Management Committee responsible for the oversight and 
development of the new Statewide Eating Disorders Service in South Australia and is a member of the Steering Committee of the National Eating Disorder Collaboration. Her current research interests are in the aetiology, prevention and treatment of eating disorders and perfectionism. She has co-written two books on perfectionism and has had over 150 publications in peer-reviewed journals. In 2015, she was elected a fellow of the Academy of the Social Sciences in Australia.

Tony Winefield was born in London and completed his BA (Honours) and PhD degrees at University College London [UCL] before coming to Australia. He joined the University of South Australia as foundation professor of psychology in 1999 after a spell at the University of Adelaide, where he remains an adjunct professor. During his time at the University of Adelaide he was dean of the Faculty of Arts, head of the Department of Psychology, and a member of the university council. He is a fellow of the Australian Psychological Society and a former APS director. Since 1978, he has been a chief investigator on twenty nationally competitive, Category One research grants (ARC, ERDC, NHMRC). In 1993, he received the Supervisor of the Year award from the University of Adelaide Postgraduate Students Association and in 2003 the Elton Mayo award from the Australian Psychological Society College of Organisational Psychologists for Outstanding contributions to Industrial/Organisational Psychology Research and Teaching. He recently won the Stress and Anxiety Research Society [STAR] 2015 Lifetime Career Award. He has published eight books, thirty-two book chapters and more than 200 refereed journal articles. 


\section{Preface}

\section{Professor Tony Winefield}

When Professor Anna Chur-Hansen invited Ted Nettelbeck and me to edit a book on the history of the University of Adelaide School of Psychology (formerly the Department of Psychology) in 2014, we were delighted and we both agreed. Since then, we have discussed the project further and agreed that it would be a good idea to broaden the scope so as to include the history of the Schools of Psychology at the other two universities in South Australia: Flinders University and the University of South Australia (UniSA). This involved inviting other people to contribute, and we have been fortunate to obtain the agreement of Professor Malcolm Jeeves, the foundation professor of Psychology at Adelaide, Professor Norm Feather, the foundation professor of Psychology at Flinders, and Professor Jacques Metzer, the founder of the school at UniSA. In addition, the three current heads of school - Professor Anna Chur-Hansen (Adelaide), Professor Tracey Wade (Flinders) and Professor Kurt Lushington (UniSA) — have agreed to assume overall responsibility for their respective chapters. Consequently, rather than assume the roles of authors, Ted Nettelbeck and I have agreed to be co-editors.

South Australia is fortunate in having three university schools of psychology that are all strong in research. The most recent Excellence in Research [ERA] ratings by the Australian Research Council awarded 4 (out of 5) to all three, indicating that their research is better than world-class.

Psychology has been defined as 'the study of mind and behaviour', but it is a profession as well as an academic discipline. As an academic discipline, there are various branches of the discipline, including experimental psychology, social psychology, physiological psychology, and abnormal psychology. Since the introduction of the Psychological Practices Act in 1973, there has been an increased focus on the professional training of psychologists along with increased regulation of the profession. The regulation of the profession has involved the Psychological Board of South Australia, since replaced by the Psychological Board of Australia [PBA], the Australian Psychological Society [APS], the Heads of Departments and Schools of 
Psychology Association [HODSPA] and the Australian Psychology Accreditation Council [APAC], established in 2009. As a profession, there are nine specialist branches as defined by the following APS Colleges: clinical; clinical neuropsychologists; community; counselling; educational and developmental; forensic; health; organisational; sport and exercise. In order to practise psychology, practitioners need to be registered by possessing APAC-accredited qualifications. Endorsement of specialty training may be granted by the PBA after further supervised practice post-registration. Continuing registration requires maintaining a logbook of professional development [PD] activities.

More details can be gleaned by reading the book itself, where we hope you will enjoy reading about the history of the psychology schools at Adelaide's universities. 


\title{
Introduction
}

\author{
Tony Winefield
}

This book does not aspire to cover the entire history of psychology in South Australian universities. Psychology, defined as the 'science of the nature, functions, and phenomena, of human soul or mind' (Concise Oxford Dictionary, 1976) or 'the systematic study of behaviour and the mind in man and animals' (Sutherland, 1989, p. 354), has been, and continues to be, taught in university departments and schools other than psychology, including education, philosophy, public health and psychiatry.

Psychology was taught for many years at the University of Adelaide well before the school (department) was established in 1955, thanks to the initiative of Jack Smart, professor of philosophy, who appointed two lecturers in psychology: Ullin Place and Syd Lovibond (see Chapter Three). Much earlier, in 1894, the university had appointed a Scot named William Mitchell (later Sir William) at the age of thirty-three as professor of English language and literature and mental and moral philosophy. In 1907, Mitchell published The structure and growth of the mind and later became vice-chancellor and chancellor. He died at the age of 101 (Duncan \& Leonard, 1973).

Although the book by Duncan and Leonard provides much valuable information, it does not mention the formation of the Psychology Department. Another recent book on the history of the Faculty of Arts, edited by Harvey, Fornasiero, McCarthy, Macintyre, and Crossin (2014), also does not mention the School of Psychology, though it was a member of the faculty until 1997, when it transferred to the Faculty of Health Sciences. Nonetheless, the School of Psychology provided three former Deans of Arts (Malcolm Jeeves, Tony Winefield and John Brebner), whereas the School of Music was never a member of the faculty.

Another famous psychologist who graduated at the University of Adelaide was George Elton Mayo. Mayo studied philosophy and psychology under Sir William Mitchell, graduating with first-class honours in 1910 and winning the Roby Fletcher 
Prize in psychology, before moving to Queensland, where he completed his MA and became a lecturer, then foundation professor, at the University of Queensland, before moving to the United States. He is well known as one of the founders of industrial/ organisational psychology and the Australian Psychological Society's College of Organisational Psychologists has named a prize after him.

This book focuses on the core activities of the three Schools of Psychology at the University of Adelaide, Flinders University and the University of South Australia. The core activities comprise undergraduate teaching, postgraduate research training, research and postgraduate professional training. The discipline of psychology has many branches. First, we can distinguish between pure and applied psychology. Second, within each of these two main branches, there are numerous sub-branches. The sub-branches of pure psychology include experimental/physiological psychology, concerned with basic processes of sensation, perception, learning and cognition; developmental psychology; and social psychology. The sub-branches of applied psychology include clinical psychology; educational psychology; health psychology; and organisational psychology.

Prior to the enactment of the Psychological Practices Act 1973 (SA), there were no external pressures on universities. The 1973 Act introduced provisions concerning who could practise psychology, and restricted the professional practice to those registered with a newly created board. This led to a proliferation of postgraduate professional training programs in applied psychology which needed to be approved by the board. Around the same time, the Australian Psychological Society [APS] introduced accreditation guidelines that set forth criteria for the accreditation of Academic Organisational Units [AOUs], which required minimum staffing levels and prescribed course content. In 2005, the Commonwealth Government and the Council of Australian Governments [COAG] established a new body, the Australian Psychology Accreditation Council [APAC], with a board of twelve directors, of whom four are nominated by the APS, four are nominated by the Psychological Board of Australia [PsyBA] and four are nominated by the Heads of Departments and Schools of Psychology Association [HODSPA]. APAC is responsible for regulating the profession, and conducts regular visits to accredited departments/schools of psychology in order to decide whether they continue to satisfy the APAC Standards.

Within the APS, there are nine specialist colleges (clinical neuropsychologists, clinical psychologists, community psychologists, educational and developmental psychologists, forensic psychologists, health psychologists, organisational psychologists, and sport and exercise psychologists). Most university departments/schools offer specialist master's or specialist master's/PhD programs. However, because the Medicare rebate is higher for clinical psychologists, some departments/schools (for example, at Flinders University and the University of South Australia) restrict themselves to this program alone. Within South Australia, only the University of Adelaide offers other 
programs (health and organisational psychology) in addition to clinical psychology. Further information concerning external pressures is provided by Neil Kirby in Chapter Four.

We are fortunate in that the foundation professors of the three departments/ schools (hereafter referred to as 'schools', which is their current nomenclature) are still alive and have been able to contribute to later chapters, although the initial head of the Adelaide school, Dr Arthur Wilkes Meadows, died in 1987. Sydney Harold (Syd) Lovibond, like Meadows, had originally been appointed as a lecturer in psychology in the School of Philosophy at Adelaide in 1954 by Professor John Jamieson Carswell (Jack) Smart, who appointed Meadows as a senior lecturer in psychology in 1955. In 1956, psychology at Adelaide was established as a separate school, and in 1957 Meadows appointed two New Zealanders, Dr Laurence Binet Brown and Dr David Norris Gibbs, and another Australian, Ronald Edgar Penny from Melbourne, in 1958. Syd Lovibond was promoted to senior lecturer in 1959 and Laurie Brown was promoted to senior lecturer in 1961. In 1959, Dr Malcolm Alexander Jeeves was appointed as foundation professor.

What follows is a broad account of how the three schools of psychology at the different universities in Adelaide have developed from their beginnings. The different chapters, of varying length, have been written by those currently involved in the operations of these schools, in some cases for considerable periods of time. That some sections are anecdotal or personal in nature is only to be expected; authors were asked to include some account of the social aspects of their school's activities, as well as to address academic aims and accomplishments. The varying narrative style of each chapter also reflects the collaborative aspect of this book.

In Chapter Two, Malcolm Jeeves, the first professor appointed to the chair in psychology at the University of Adelaide, and Tony Winefield, a member of the academic staff from 1962 until his move to the University of South Australia [UniSA] in 1999 to his current position of foundation professor of psychology, have provided a lively account of the first forty years of psychology at the University of Adelaide. Aided by the autobiography of Professor Norman Munn (1902-93), a South Australian academic and textbook author whose career was largely in the US, Jeeves and Winefield have charted the development of the Department of Psychology from its earliest beginnings in the Department of Philosophy, its emergence in 1956 as a small department staffed by a handful of lecturers, through the rapid development that followed Professor Jeeves's appointment in 1959. As noted by Norman Munn (1980, p. 146) when he revisited Adelaide during late 1960, he 'found an amazing transformation'; and this was to continue for the next decade as Jeeves substantially expanded research and teaching interests in human and animal experimental psychology. During this time, Jeeves was involved in plans for the establishment of psychology at the new Finders University, and several senior staff left Adelaide to take up professorships elsewhere, being replaced 
by new appointments, principally from overseas. By 1969, when Jeeves left to take up a chair at the University of St Andrews in Scotland, the University of Adelaide department represented a thriving scientific discipline fostering diverse teaching and research activities across a broad spectrum of psychology.

The decade from 1970 began under the leadership of Professor Alan Welford, brought from Cambridge as the last non-elected professorial head of psychology for almost thirty years. From this time until the appointment of Professor John Taplin in 2000, the department operated under a system of elected chairpersons, which was introduced by the university council in 1974 in order to democratise the university. During this period of about twenty-five years, the department had six different elected chairmen, although Christopher Cooper served as chair for much of that time. Cooper's tenure was characterised by sound management, a highly stable staffing profile and, at the end of 1997, the relocation of the department from the Faculty of Arts to the Faculty of Health Sciences. By 1999 the opportunity had been created to re-establish the chair in psychology with an outside appointment.

In Chapter Three, Anna Chur-Hansen has provided an account of the history of what can be seen as a second stage in the development of psychology at the University of Adelaide. This time followed a long period of stability following the retirement of Professor Alan Welford in 1979, with only a few changes to course structures and research directions and to the profile of academic staff involved. However, the appointment in 2000 of Professor John Taplin, following close on the Department of Psychology's transfer from the Faculty of Arts to the Faculty of Health Sciences from 1998, opened a new era of innovation and extensive revitalisation. These changes, carried forward during the successive headships of Professors Ted Nettelbeck, Deb Turnbull, John Dunn and Anna Chur-Hansen, have served psychology well and brought it to the point where, today, its staff represent diverse research and teaching interests in health, disability and lifespan, brain and cognition. Now established as an independent school under the umbrella of the Faculty of Health Sciences, the School of Psychology provides a wide range of nationally accredited courses and programs that service some 1100 undergraduates, including sixty honours students annually, across a wide range of undergraduate courses and programs; forty postgraduates completing coursework programs in clinical, health and organisational areas; and eighty-five candidates for the $\mathrm{PhD}$ degree.

Chapter Four outlines how, across a span of some forty years, psychology as taught at the University of Adelaide was transformed from a program virtually entirely derived from experimental psychology — the pinnacle of which was an honours degree, followed in relatively rare cases by a PhD degree — to a broader base that met the aspirations of a majority of students to train for entry to the profession as applied psychologists working in clinical health and organisational domains. This chapter has been written by Neil Kirby, who, with forty-six years of experience as an academic 
within the School and former Department of Psychology, can now claim to have worked there for longer than any other member of staff in the history of the school. He has provided an avowedly personal perspective of events across a period equivalent to about two-thirds of the time since the Department of Psychology was established at the University of Adelaide.

In his chapter, Kirby has threaded two themes through an account laced with amusing anecdotes of how these extensive changes emerged. The first theme gives due credit to the staff given the responsibilities for effecting these changes, who were required to undertake the work involved without the provision of much by way of additional resources. The second recognises the extent to which these changes to a more applied perspective have been accompanied by significant changes to the gender mix of students, with numbers of female students increasing at all levels. In part, the change in gender mix has been a consequence of improved access for women to tertiary education and to professional careers reflecting that training. This trend has particularly been the case for the three master's programs in clinical psychology, health psychology and organisational psychology and human factors, but it has also impacted $\mathrm{PhD}$ completions beyond the mid-1990s. As an organisational psychologist with extensive experience with attempts to use psychological principles to achieve changes in real-world situations, Kirby also draws attention to the difficulties of maintaining such changes over time.

In Chapter Five, Leon Lack has taken a somewhat different approach to that taken by authors of other chapters when documenting the almost fifty years of the history of psychology at the Flinders University of South Australia, by collating perspectives provided by several past and present members of the academic and professional staff with his own contribution. Thus Norm Feather, the founding professor and head from 1967, just a year after the university was established, has provided a detailed account of how psychology at Flinders came into existence. From the outset, a strong emphasis was given to social psychology.

An important initiative from these early days was the founding in 1972 of the Flinders Conference on Social Psychology, which, over more than forty years, has evolved into the foremost annual forum for social psychologists, held at different locations throughout Australia and New Zealand by the Society of Australasian Social Psychologists. However, Feather's intention was always that social psychology should form part of a broader curriculum that included a wide range of subdisciplines (experimental psychology, cognition, physiological bases to psychology, developmental psychology, differential psychology, environmental psychology, organisational psychology and so on), thereby ensuring a broad representation of the full discipline. Feather's tenure was marked from the outset by his encouragement of diverse research activities, which undoubtedly helped from a very early stage to establish the international reputation of psychology at Flinders for research of high quality. 
Nigel Bond, an experimental psychologist and head of psychology at Flinders from 1992 to 1996, has included in this chapter a lively account of challenges that he encountered on his appointment. He focuses particularly on the development of recruiting strategies that could attract the most academically able students at the end of secondary education to choose psychology at Finders in preference to the University of Adelaide. At the time, the University of Adelaide was widely held within the broad Adelaide-and-suburbs community to be a more desirable choice, doubtless because it was the older institution (established 1874) and centrally located with a city campus. Bond's solution, which proved hugely effective, was to establish a number of flagship programs: a Bachelor of Psychology (Honours) that guaranteed students selected for first year under highly competitive criteria to a place in the fourth-year honours course, thereby enhancing appreciably their chances of entering the profession via master's training; a less generalist Bachelor of Cognitive Science; and a Bachelor of Behavioural Science program that widened students' options for honours beyond psychology to include possible places in cognate areas.

Another initiative of Bond's was to provide opportunities for earlier graduates, who later in life were considering changing careers, to undertake training to become psychologists. Until the availability of the Graduate Diploma in Psychology at Flinders, a program that provided the prerequisites for honours entry within a single year, anyone who decided to try for late entry to the profession faced a very gruelling three years of additional undergraduate study. The option at Flinders was therefore very attractive.

Peter Wilson, who followed Bond as head (1997-2000), showed similar initiative, establishing the first fully integrated master's/ $\mathrm{PhD}$ degree in Australia, a novel way of ensuring that those students qualifying for postgraduate research training also got to develop the required clinical training for entry to the profession. Another striking characteristic of this combined program was the introduction of the opportunity for the thesis to be presented as a sequence of published papers. These changes were highly innovative; and as can be seen from other chapters, the other schools at Adelaide and the University of South Australia [UniSA] were quick to pick up on and introduce these options. Wilson's other important contribution to postgraduate professional training was to establish, in co-operation with Chris Cooper at Adelaide and Jacques Metzer at UniSA, a committee with representation from all three universities, the task of which was to manage the allocation of limited supervised field placement locations, as required for the accreditation of coursework master's degrees, to increasing numbers of students seeking to enter the profession. This initiative was to develop over several years into the University Placement Allocation Committee, which continues to fill this role very successfully.

Leon Lack - together with a contribution from Paul Douglas which describes the evolution of technical support - has fleshed out the wider university context within which psychology was located. He includes an account of the infamous occupation 
of the Registry in 1974, an event in which two staff, members of the APS, became embroiled. His brief description of International Rules Volley Ball at Flinders (which some will insist is a sorry child of Adelaide's Australian Rules Volleyball) confirms that life at Flinders has included recreational aspects. A common thread that runs through the accounts of the various contributors is that psychology at Flinders has, since the beginning, been a happy environment within which to work.

Tracey Wade's account in Chapter Six of the more recent history of the School of Psychology at Flinders University picks up the story from 2000. In 2008, the school was recognised by the university as an area with research strengths in five domains: clinical and health psychology, developmental psychology, memory and cognition, neuroscience and psychophysiological psychology, and social psychology. The chapter highlights, through a series of essays by the members of the academic staff most responsible, those research activities that have attracted competitive external funding. These include the research of the eyewitness memory laboratory; the study of cognitive processes underlying food cravings; research activities within the sleep laboratory; the exploration of life span development and ageing; the study of post-traumatic stress disorder, memory for traumatic experiences, body image, and the aetiology, prevention and treatment of eating disorders; and the development of justice restoration theory.

The picture that emerges is of a vigorous, high performing school, staffed by scholars and researchers recruited from throughout the world, which has expanded way beyond the relatively narrow initial plan formulated in the late 1960s for a centre for social psychology. It now offers learning and research opportunities for students in diverse areas of psychology, including some not found at the other two universities.

The history of the School of Psychology at the University of South Australia has been set out in Chapters Seven and Eight. This is a shorter account than has been included for the other two schools but, as clarified above, the book is not intended to be a comprehensive history of psychology at each of the three universities in South Australia. Rather, we have seen it as an opportunity for staff in the three schools, past and present, to provide personal perspectives that they regard as having broad interest. In Chapter Seven, Jacques Metzer, the first head of school from 1994, has outlined the background, sometimes beset by political machinations, which led to the establishment of the school. Initially limited by psychology's prior main role within the previous College of Advanced Education system as a discipline servicing other health sciences professions, the new school quickly moved to lay the necessary groundwork for establishing courses that could be located within a named degree and would meet the accreditation requirements of the Australian Psychological Society. Strategies were quickly developed to build academic seniority and to lay the groundwork for extending already-existing research activities among staff. Early advances were made with developing forensic psychology as a domain allied with a new Forensic and Applied Psychology Group and with the formation of a Work and Stress Group merged with 
a Centre for Applied Psychological Research. Other initiatives were the establishment of a new Psychology Clinic, allied with a Master of Psychology, which built in part on an earlier Diploma in Counselling, a professional doctorate and the development of a new $\mathrm{PhD}$ program. Considerable effort was invested in growing international student numbers, both internally and offshore.

In Chapter Eight, the current head, Kurt Lushington, has outlined changes to leadership, staff, research focus and degree programs within the school in the past decade. Foremost among these has been the merger between the School of Psychology and the School of Social Work and Social Policy, with almost all areas of the discipline of psychology brought together at the Magill campus. Recent growth in the number of professional staff available to contribute to the management of financial, business and administrative arms of the school has also assisted the reorganisation of teaching programs. Other major changes have involved the discontinuation of onshore and offshore postgraduate training programs in counselling, although the school has recently been able to offer new undergraduate counselling courses and has become involved in helping to deliver a Bachelor of Psychological Science in Hong Kong.

The school has also increasingly been concerned to develop new pathways for those psychology undergraduates who do not go on to postgraduate studies in psychology. The appointment of new high-performing research staff has enabled the school to generate a culture that values research success, with a consequent improvement to its ERA [Excellence in Research Australia] rating. This has risen from a rating of 2 (below world standard) in 2006, to the maximum 5 (well above world standard) in 2015, an outcome better than that achieved by the schools at Flinders or Adelaide (both 4, above world standard).

Given that the accreditation requirements for courses relevant to the education and training of students seeking to enter the profession and discipline are determined by the standards and guidelines established by the independent Australian Psychology Accreditation Council Limited [APAC], it is only to be expected that there will be similarities between the courses offered by the three schools at UniSA, Flinders and Adelaide, particularly at undergraduate levels. Nonetheless, it is clear that the school at UniSA has distinguished itself from the schools at Flinders and at Adelaide in a number of ways, including the establishment of regional teaching units at Whyalla and Mount Gambier and the development of curriculum material for teaching indigenous psychology. University policy that has enabled the school to employ academic staff in teaching-only positions has also resulted in a wider diversity of career pathways. Moreover, more consideration to promoting the work-readiness of undergraduate students has resulted in more engagement between the school and industry, as well as curriculum changes to improve graduate employability. A Centre for Applied Psychological Research, superseded recently by a new Asia Pacific Centre 
for Work Health and Safety, has successfully promoted the application of psychological knowledge within the workplace, including work health and safety, for more than a decade.

Other recent developments have been a new Bachelor of Psychological Sciences (Cognitive Neuroscience); revitalised opportunities for sleep research, including the interface between sleep and cognitive neuroscience and neurolinguistics, following the relocation in 2012 of the former Centre for Sleep Research to Central Queensland University; and expansion to clinical research including forensic psychology, the provision of psychological services via telecommunication technologies, and cancer research.

Taken together, the chapters that follow provide an interesting snapshot of how education and training in psychology has expanded beyond its modest presence more than sixty years ago as part of a Bachelor of Arts degree at the University of Adelaide. Psychology now provides a diverse range of undergraduate and postgraduate courses and programs at all three universities in Adelaide, supported by the research activities of a large collective of academic staff which has been recognised as meeting international standards of excellence. Changes accompanying this growth have included a huge increase to the numbers of students seeking to engage with the discipline. The other major change during this time has been a shift from a discipline dominated by theories of learning to an ever-increasing emphasis on the implementation of evidence-based applications. Challenges for the future will include continuing to find improved ways of delivering high-quality specialised training in different fields of psychology to increasing numbers of interested students.

\section{References}

Duncan, WGK, \& Leonard, RA. (1973). The University of Adelaide 1874-1974. Adelaide: Rigby.

Harvey, N, Fornasiero, J, McCarthy, G, Macintyre, C, \& Crossin, C (Eds.). (2014). A history of the Faculty of Arts at the University of Adelaide 1876-2012. Adelaide: University of Adelaide Press.

Mitchell, W. (1907). Structure and growth of the mind. London: MacMillan.

Munn, NL. (1980). Being and becoming: An autobiography. Adelaide: Adelaide University Press. Sutherland, NS. (1989). MacMillan dictionary of psychology. London: MacMillan.

\section{Legislation}

Psychological Practices Act 1973 (SA). Retrieved from https://www.legislation.sa.gov.au/LZ/ C/A/PSYCHOLOGICAL\%20PRACTICES\%20ACT\%201973/2010.06.30/1974.37. UN.PDF. 



\title{
The origins and early history of the University of Adelaide's School of Psychology
}

\author{
Malcolm Jeeves and Tony Winefield
}

\section{Part 1: $1955-69$}

\section{Malcolm Jeeves}

The late 1950s and the 1960s were a time of very rapid expansion and development for the University of Adelaide. The vice-chancellor in the 1950s, AP Roe, had embarked on a policy of headhunting worldwide for young leaders in various academic disciplines. For example, in the late 1950s he had appointed Hugh Stretton, dean of an Oxford College, as professor of history; John Trevaskis, a Cambridge classicist, as professor of classics; Jack Smart, a distinguished Oxford philosopher, as professor of philosophy; and Henry Bennett, a Cambridge geneticist and student of RA Fisher, as professor of genetics. In 1959, seemingly continuing this practice, AP Roe's successor, Henry Basten, appointed Malcolm Jeeves, a Cambridge-trained psychologist aged thirty-two, to the newly created chair of psychology.

But this was not the beginning of psychology at the University of Adelaide. We are fortunate that, in an earlier publication by the Adelaide University Union Press of a book by Norman Munn entitled Being and becoming: An autobiography (1980), we have a number of references to the way in which psychology developed in the years before 1960. Norman Munn was born in South Australia in 1902, but in 1923 went off to North America for his education and to make his name as one of the best-known and most distinguished textbook writers of psychology in the mid-twentieth century. 


\section{Pre-1960 psychology at the University of Adelaide}

Reporting on a visit to Adelaide in 1948, Munn wrote:

There was still no psychologist at the University of Adelaide, although a course was given in the philosophy department. Mrs Amy Wheaton, a neighbour from my childhood youth, was Lecturer in Sociology and taught a course on Social Psychology in that department. In response to Amy's invitation, I gave a lecture on Personality to her students during this visit. (1980, p. 129)

Writing further about these early developments, Munn noted that during a visit to Adelaide in August 1951

[w]e settled in for a stay of almost four months with my mother, who still lived in our original house, and brothers and sisters and their families ... I busied myself with chores after buying some workmen's clothes for the purpose. This activity was most enjoyable, not only because it was a help to my mother, but also because of the physical exercise involved. (p.135)

He then goes on:

When I had been at this for some weeks, and on a day when I had not yet shaved, and had become quite dirty and disreputable in appearance while grubbing at such tasks, a young man came to the gate and asked whether this was where Professor Munn was staying. He seemed very surprised when I said, 'I am Professor Munn'. He then introduced himself as Ullin Place, and said that he had been appointed the year before as Lecturer in Psychology in the University of Adelaide's Philosophy Department. What he wanted particularly, was my help in setting up a psychological laboratory. There was no psychology department, but Place had been given a large room in which experiments might be done by his students. This needed modification. When we got together at the University later and I could examine the room, I suggested an arrangement of cubicles, tables, and other structures along the lines of our Bowdoin setup. The room was eventually remodelled in the way I suggested. At Place's invitation I also gave some lectures to students while in Adelaide. (p. 136)

In 1957, during another visit, Norman Munn recorded that

[t] he University of Adelaide at last had a Department of Psychology, having separated from philosophy only the year before. Ullin Place had returned to England and they now had one senior lecturer (Arthur W Meadows) and two lecturers (Sydney Lovibond and Laurence Brown). I visited with these and also gave a lecture to the staff and students. (p. 143)

Thus we see that in 1957 Arthur Meadows was appointed senior lecturer and head of psychology, in the same year Sydney Lovibond, Laurence Brown and David Gibbs, the latter two New Zealanders, were appointed as lecturers. Soon afterwards, in 1958, Ronald Penny was appointed as a lecturer. When Malcolm Jeeves was appointed in 1959, Arthur Meadows decided to leave the department, but not before he had 
helped Jeeves to assume his new responsibilities at the university. Thus the staff that Malcolm Jeeves inherited were Sydney Lovibond, Laurence Brown, David Gibbs and Ronald Penny, all but one of them older than him, but all of them most co-operative in welcoming this young 'pommy' as he began to settle in to Adelaide.

\section{Rapid developments following the creation of the chair of psychology}

Arriving in Adelaide in January 1960, Malcolm Jeeves was extremely fortunate to find that he had the full and enthusiastic support of the then vice-chancellor, Henry Basten, and other senior members of university staff in developing the Psychology Department. There was great student demand, as Jeeves found when he began to teach the first-year course, in which many hundreds of students had enrolled. Fortunately, having assessed the existing strengths of the department, he was soon able to make a series of excellent appointments to ensure that the wide field of knowledge by then encompassed under the heading psychology would be adequately covered in both teaching and research. Already, there were strengths in social psychology, psychometrics and studies of basic learning processes. Jeeves was soon able to make appointments in experimental psychology, biological and biochemical bases of behaviour, human factors, cognition and developmental psychology. Even before he had left the UK, he had been able to identify and recruit a young Australian at University College London, Peter Glow, who was completing a $\mathrm{PhD}$ in aspects of the biochemical basis of behaviour. He had also been able to recruit a distinguished mathematician, Zoltan Dienes, whom he had met and whose work was already being applied in improving the teaching of mathematics in schools. Dienes had benefited from spending time with Professor Jerome Bruner at Harvard University, one of the leaders in cognitive psychology. Jeeves had himself spent a year researching with Bruner at Harvard in 1953-54.

Returning to Adelaide again in late 1960, Norman Munn records:

I went to the University of Adelaide to see what was happening in the Department of Psychology and found an amazing transformation, not only in the physical aspects of the Department but also in its staff. At long last, there was a Professor of Psychology, Dr Malcolm Jeeves, formerly associated with Sir Frederic Bartlett and Professor Alan T Welford at Cambridge University. The additional staff had increased to five. Sydney Lovibond was now Senior Lecturer, Laurie Brown was still there as Lecturer, and there were three new Lecturers: David Gibbs, Ron Penny and Peter Glow. Jeeves was interested in establishing a marsupial laboratory in addition to their rat colony and, in expressing interest, I told him that I had long wished to study learning in kangaroos. (1980, p. 146)

Further appointments were soon to be made. In 1961, Lambros Houssiadas, whom Malcolm Jeeves had met in 1957-58 when Lambros was a PhD student at Leeds and Jeeves was a lecturer there, was appointed as a lecturer. Lambros had carried out research on Michotte's ideas of causality and had produced an excellent $\mathrm{PhD}$ thesis 
examined by Sir Frederic Bartlett. He had special skills and interests in Piaget's work in developmental psychology. In 1962, the department recruited Francis Dalziel, a graduate of Aberdeen University who had worked in North America and was an ideal person to teach Skinnerian theories of learning and conditioning. Also in 1962, Jeeves was able to appoint another distinguished graduate of University College London, Anthony (Tony) Winefield who brought extremely valuable skills, not only as an experimentalist but also as a skilled statistician, whose advice in the developing work by Malcolm Jeeves and Zoltan Dienes proved to be invaluable. Tony Winefield was later promoted to senior lecturer, then reader, and is currently the foundation professor of psychology at the University of South Australia (UniSA).

In the same year, 1962, the university agreed to advertise a readership in psychology and during a short visit to the UK Malcolm Jeeves was able to interview short-listed candidates. The department was extremely fortunate in appointing Kenneth Provins, at that time working at an MRC Unit in the anatomy department at Oxford. He was a specialist in human factors and especially in understanding the importance of environmental factors on human performance - specifically, in his case, the effect of heat stress. Having by now lived in Australia for a few years, Jeeves had realised that this was an important topic of direct relevance to human factors research in Australia. In subsequent years, Kenneth Provins became well known in Australia. He moved from Adelaide to become professor of psychology at the Australian National University in Canberra, before returning to Adelaide as deputy vice-chancellor.

Relevant to what was happening around this time were references in Norman Munn's accounts of the developing Department of Psychology at the University of Adelaide. We may note how he writes that

during the September following my remarriage [1961] ... an invitation came from the University of Adelaide to return for one year as Visiting Professor of Psychology. The interest of Professor Jeeves in marsupial behaviour and his knowledge of my interest in studying the learning ability of kangaroos was responsible for this invitation. (1980, p. 148)

Finally, Norman Munn wrote, 'we reached Adelaide early in September 1962 and took up residence in West Croydon, about 10 minutes by train from the city'. He continued:

The University of Adelaide provided an office in the psychology department, a typewriter, and various other facilities, including a service, when needed, of all the departmental secretaries. I was invited to lecture to the staff and in various courses, and I did so from time to time, but my main concern was research with kangaroos. The Department now spread over a large portion of the same building in which I had helped Ullin Place arrange his one-room laboratory in $1952 .{ }^{1}$ It also had an

1 Munn is here referring to the old Prince of Wales building, replaced by the Hughes building in 1973. 
outside extension to house relatively small marsupials such as possums, wallabies and quokkas. But there was insufficient space for kangaroos, not to mention a large apparatus required in studying their ability to learn. I was encouraged to settle for some smaller marsupial like the quokka, which could be brought in from Western Australia, but my heart was firmly set on research with kangaroos. It then became obvious that I would have to find larger quarters than were available in the Department itself. Dr Peter Glow, now Senior Lecturer in the Department, came to my help by driving me to the Waite Agricultural Research Institute, a branch of the University of Adelaide located about 5 miles from the city. Here we arranged for the use of a yard with shelter and water, where I could house kangaroos and carry out my experiments. The Waite Institute also offered to provide suitable food for kangaroos in captivity - a mixture of chaff, rolled oats, wheat, bran, and wheat germ. As a special treat for making correct responses during the training sessions the kangaroos would get an assortment of bread, carrots and lettuce. (p. 151)

\section{Psychology in the 1960s - A period of sustained expansion and consolidation: Making links locally, nationally and internationally}

\section{Further academic appointments}

In 1965 Ian John, an Adelaide graduate who obtained his master's degree in Melbourne, with interests in psychophysics, was obtained. John was promoted to senior lecturer in 1969, to reader in 1973 and to professor in 1973. During the 1960s, Malcolm Jeeves recruited two more lecturers from the UK: Eric Rump, a graduate from University College London [UCL] who was lecturing at the University of Manchester, with research interests in experimental aesthetics and creativity; and Peter Delin, a University of Oxford graduate who had worked as a research assistant for the famous social psychologist Dr Michael Argyle. Delin's interests included mnemonics and parapsychology. Jeeves's last appointment was Mr Christopher Cooper, an Adelaide medical graduate who had been enrolled in a $\mathrm{PhD}$ with Ken Provins.

\section{Fruitful links within the university}

As it became evident that the Department of Psychology was, in keeping with similar developments worldwide, establishing psychology as an evidence-based scientific discipline, this led naturally to the provision of courses within the Faculty of Science at the University of Adelaide. The new Professor Malcolm Jeeves, having read natural sciences at Cambridge before reading experimental psychology, was able to gain the confidence of scientists within the Faculty of Science with similar natural science backgrounds. He was greatly helped in this endeavour by some of the new appointments like Peter Glow and Kenneth Provins, who likewise had firm roots in well-established scientific disciplines such as biochemistry, anatomy, physiology and zoology. At the same time, with the arrival of Zoltan Dienes, effective links were made 
with the university's Department of Education, where the newly appointed professor of education, Laurence Neil, was keen to collaborate. At the same time, Zoltan Dienes quickly made links with the South Australian Education Department as soon as his remarkable skills at introducing mathematical concepts (for example, set theory) to young children were appreciated.

More specifically, the links with anatomy and physiology through Kenneth Provins were not the only instances of collaboration between the department and other bodies. There were already links in place with the Royal Adelaide Hospital, through David Gibbs and Laurence Brown using their skills in psychometric assessment as honorary clinical assistants. These links were more firmly established when Malcolm Jeeves was appointed honorary psychologist at the Royal Adelaide Hospital, with a special interest in the assessment of referrals from neurology and neurosurgery. He was soon collaborating regularly with neurosurgery and neurology at the Royal Adelaide Hospital as well as with the professor of paediatric neurosurgery at the Adelaide Children's Hospital. ${ }^{2}$ Arrangements were made for medical students, at the completion of their preclinical years, to intermit for a year and study psychology. Their year studying psychology included working on a small research project cognate with psychology and medicine.

Soon after Malcolm Jeeves's arrival in Adelaide, a young Edinburgh graduate with a first-class degree in psychology used a commonwealth scholarship to enrol as a PhD student to work with Malcolm Jeeves on the effects of hypoxia on behaviour. This involved both laboratory studies with animals and research with humans. The research with humans was greatly facilitated by the use of the decompression chamber of the Royal Australian Air Force in Melbourne, where Frank Ledwith, the Edinburgh student, carried out many of his studies. The animal studies were carried out with rats in the Adelaide laboratories. Some of these links with aspects of human factors research were greatly facilitated by the fact that Malcolm Jeeves had for a while worked in a research unit at the University of Cambridge, where he studied the effects of ageing on human performance. This also led to him being retained as a consultant for the Aeronautical Research Laboratories in Melbourne. Links with these laboratories led to much fruitful research and several publications.

A sequel to this was that, after Malcolm Jeeves in 1969 moved from Adelaide to St Andrews in Scotland, one of his first research students there was a graduate from the Australian National University [ANU] in psychology who had been taught by Kenneth Provins. Provins had by that time become professor of psychology at the Australian National University. This young researcher - Group Captain (reserve) in the Royal Australian Air Force, Dr Robert Lee — was later to become one of the leading figures

2 The Adelaide Children's Hospital amalgamated in 1989 with the Queen Victoria Hospital to form the current Women's and Children's Hospital. 
in air accident research in Australia and worldwide, and in due course he was made a member of the Order of Australia for his outstanding contributions.

In the early 1960s, the professor of child health at the University of Adelaide had been asked to help with problems faced by the government in supporting aboriginal communities around Alice Springs. There had been chronic ill health and high levels of infant morbidity and mortality in these communities. After a thorough investigation, he concluded that it was not first and foremost a medical issue but resulted instead from deeply ingrained habits of engaging in ancient nomadic customs during certain crucial periods of early infant development. As a consequence, Professor Jeeves at Adelaide and Professor Cecil Gibb at the Australian University were jointly invited to see what help they could give. Government funding was provided and after preliminary investigations it was agreed that the issue was indeed related to cultural customs. A highly qualified postdoctoral student in ethology, Peggie Thornton from Cambridge University, was appointed to lead the research on the spot.

\section{Adelaide psychologists ' wider involvement in the development of Flinders University}

By the mid-1960s, the decision had been taken to establish a second university in South Australia. A small committee - chaired by Professor Peter Karmel, at that time chairman of the Education Committee at the University of Adelaide, and including Professor Jeeves - was set up to give advice on the early planning of this new university, which would come to be known as Flinders University. It was early on decided that there should be a psychology department at Flinders and that it should be one that would complement the strengths of the department at the University of Adelaide. When a committee was set up to give advice on the sort of person to be appointed, it included, and was therefore able to draw upon the invaluable advice and wealth of experience of, Professor Norman Munn, and it was decided that the first professor at Flinders should be a distinguished social psychologist. In the event, the university appointed Professor Norman Feather.

By the end of the 1960s, senior staff from the Adelaide Department of Psychology were moving to take up professorships in other universities within and outside Australia. Sydney Lovibond moved to be professor of psychology at the University of New South Wales; Laurence Brown moved to be professor of psychology in New Zealand; Zoltan Dienes moved to a professorship in North America; and Lambros Houssiadas was invited to return to Greece and become the first professor of psychology at the University of Thessaloniki. At the latter, he was the founder of the Psychology Department. Syd Lovibond, once famously described by Secretary Sandra Naish as 'the only practising Australian in the Department', went on to develop the Psychology School at the University of New South Wales [UNSW] as one of the best in Australia. With his son Peter (now professor of psychology at UNSW) he developed 
the well-validated and widely used Depression, Anxiety and Stress Scale [DASS] (Lovibond \& Lovibond, 1995). In April 2015, Peter Lovibond took Helen and Tony Winefield to visit his father, then ninety-six, living very happily in a nursing home in Randwick. The Winefields reported that he was delighted to see them.

\section{A uniquely Australian research project}

Professor Norman Munn, recording how he had always wished to conduct research on kangaroos, wrote that behind his planning for research on these animals

was my desire to contribute relevant information on an issue in which Professor Jeeves and some of his associates including visiting Indian psychologist Mrs Rajalakshmi were involved. This issue concerned what Jeeves had called a 'reversal index'. (1980, p. 152)

Munn continued that

the literature on animal learning contains many studies in which after learning to discriminate between two patterns, where response to one is rewarded, the reversal discrimination is learned - that is with the previously negative stimulus now rewarded. It is most often found, in such research that many more trials are required, and many more errors made, in learning the second than in learning the initial discrimination. Rajalakshmi and Jeeves concluded that the number of trials or errors involved in learning the reversed discrimination, divided by the number of trials or errors involved in learning the initial discrimination, might provide a phylogenetically useful indication of animal intelligence. (p. 152)

Munn continued (p. 152): '[T]hey were interested in obtaining a reversal index for kangaroos, so my use of visual discrimination learning could contribute to this project'.

Malcolm Jeeves's research into reversal learning was greatly facilitated and advanced by the co-operation and involvement of Tony Winefield. He came to the research with new ideas, and this led to the design of a new form of maze and the writing of research papers jointly by Tony Winefield and Malcolm Jeeves, which came to be regularly referred to in standard works on animal learning — such as The psychology of animal learning by Professor Mackintosh (1974), professor of psychology at Cambridge.

Already, by 1962, there were facilities in the psychology department for housing small marsupials such as possums, bandicoots and quokkas, and studies of discrimination learning and reversal learning were well underway. Frank Dalziel had been carrying out similar studies with bandicoots. In due course, the group from Adelaide presented the results of its researches at a half-day meeting at the Canberra Annual Conference of the Australian and New Zealand Association for the Advancement of Science, specifically focused on marsupial behaviour. Professor Munn presented the results of his research at this meeting and they were subsequently published in the Australian Journal of Psychology, together with similar studies by Jeeves and Rajalakshmi. 
Malcolm Jeeves had a second reason for being particularly interested in the understanding on marsupial behaviour. This arose from the long-term interest in, and many research publications of, the then professor of anatomy at Adelaide, Professor Andrew Abbie, into the evolutionary significance of marsupial brains. Andrew Abbie had noted that unlike eutherian mammals, marsupials did not possess the major structure connecting the two cerebral hemispheres - namely, the corpus callosum. As part of his duties at the Royal Adelaide Hospital working with neurosurgeons, Jeeves had conducted detailed studies of a small boy with a condition known as callosal agenesis or, in other words, lack of the corpus callosum from birth. A question that intrigued both Jeeves and Abbie was: What were the structures in the marsupial brain that functioned in the same way as the corpus callosum in eutherian mammals? The most likely candidate seemed to be the massa intermedia. It had been Jeeves's intention to pursue further specific researches on that question through neuropsychological studies on marsupials, but this intention was never realised once he left Adelaide in 1969 for St Andrews in Scotland. He was, however, able to acknowledge his indebtedness to Professor Andrew Abbie when, in later years, he returned to give the annual Abbie Lecture in the medical school at the University of Adelaide on the functions of the corpus callosum.

\section{Enriched by visiting scholars}

The work of the developing Department of Psychology at Adelaide in the 1960s was regularly enriched by the contributions of visiting scholars. These included Dr Rajalakshmi, who has already been mentioned. Dr Rajalakshmi was the wife of the professor of biochemistry from the University of Baroda in India, who had come to work for a year in the biochemistry department in Adelaide. Another visitor was Dr Robert Thouless, reader in psychology at the University of Cambridge, who not only was an experimentalist interested in psychophysics but also had written on the psychology of religion, a topic on which Dr Laurie Brown in the Adelaide department was publishing many papers. Yet another contributor was Dr Norman Dixon, a former friend and teacher of Tony Winefield at University College London, who contributed significantly to ongoing researches in psychophysics in the Adelaide department.

In 1966 Dr Alan Welford, formally director of the Nuffield Research Unit on Ageing at Cambridge, a fellow of St John's College and a member of the faculty at the University of Cambridge, came to spend six months in the Adelaide department. Welford's early career had been shaped by research during World War II at the Experimental Psychology Laboratory in Cambridge. He was the recipient of several academic honours, an active researcher in gerontology, a foundation editor of the journal Ergonomics, and the author of several successful books, the most widely acclaimed of which was Fundamentals of skill (Welford, 1968), for many years an essential text in courses here and elsewhere in human information processing. Alan Welford had been 
one of Malcolm Jeeves's teachers at Cambridge. He made significant contributions to the ongoing work of Kenneth Provins, who by that time had established his laboratory studying the effects of heat stress on performance. Welford so much enjoyed his time in Adelaide that within a few years he returned to Adelaide to become, at that time, the second professor of psychology at the University of Adelaide. Shortly after Malcolm Jeeves moved from Adelaide to St Andrews University in 1969, Alan Welford took over as head of department.

\section{Part 2: 1969-99}

\section{Tony Winefield}

\section{Tenured academic staff 1955-99}

Jeeves's final academic appointments in 1967 were Douglas Vickers, an Edinburgh graduate, and Donald NcNicol, who had completed his honours degree at Adelaide in 1963. Both completed their PhDs under Welford at Cambridge. Don McNicol, whose main research area was signal detection theory, later moved to the University of New South Wales, was then appointed to the chair of psychology at the University of Tasmania and eventually became vice-chancellor at the University of Sydney. ${ }^{3}$

Another colleague who also died prematurely was Frank Dalziel in 1999 at the age of sixty-four. Dalziel, whose main research was on Sidman avoidance conditioning, which involved administering electric shocks to rats, was subjected to opposition by students representing the animal liberation movement. Following an incident in which one of his lectures was disrupted, he switched his research area to observational studies of zoo animals. Dalziel was much loved by students and had a wonderful sense of humour. A eulogy given by John Brebner, a fellow Aberdonian, at the funeral is reproduced below from the school's homepage: ${ }^{4}$

\section{Eulogy for Frank Dalziel (by John Brebner)}

It is with sadness that we are here to farewell Frank, but, as we know he would have wished, we are also here to celebrate his life with happy memories. In my few minutes I will talk about Frank's early years, and a little about Frank in his last months. Let me start with Frank as a student. His schooling was at Aberdeen Grammar School which, if you asked if it was one of the old Grammar schools, he might tell you was founded in the year 800 , sometimes adding AD. That was his way of letting you know he was not being pretentious, and Frank was never

3 More details about Doug Vickers are contained in his obituary by Michael Lee, which can be viewed on the 'Memorials' page of the School of Psychology's website (http://health. adelaide.edu.au/psychology/people/memorials).

4 See http://health.adelaide.edu.au/psychology/people/memorials. 
pretentious. He also revelled in the knowledge that the Grammar School's most famous Old Boy was that mixture of poet, soldier, and reprobate, George Gordon, Lord Byron.

Frank went to Aberdeen University in 1953 where he took a First Class Honours degree in Psychology and then his PhD. Aberdeen University had 1850 students then, and more academic staff than Adelaide University has now. It was a leisurely life. Wednesday afternoons were reserved for sport, which meant Frank went to the pictures or watched TV. There were hour long coffee breaks mid-morning and afternoon at the Auld Toon Cafe, and an even longer lunchtime to allow students time to travel between the two campuses. During these breaks, which, through the reinforcing effects of coffee and food, set a pattern for Frank that some of you will recognise, he would amuse us and on one occasion, I recall, regaled us with his theory about his dog Tim's erratic behaviour. Tim behaved normally most of the time but occasionally became violently aggressive if he met any black and white dog. Frank's explanation was that Tim's eyesight was failing, and when he saw a black and white dog it looked like a black dog with bites out of it! And that was how Frank's interest in animal behaviour began.

Frank could always make anything funny, no subject was safe from his humour. He became one of the scriptwriters of the student shows, musicals really, that used to run for a week at His Majesty's Theatre with the proceeds going to charity.

But Frank also had another existence. Every summer he would don a dark blue uniform with silver buttons, a peaked cap, and strap his equipment round his waist. Then he was ready to board his transport and call out, 'Fares, please'. He was a tram conductor during the long vacations. Many students, including my wife Jill and her sister, would miss several trams until Frank came along to enjoy his humour and banter with the passengers on the way down to the Sea Beach. Naturally, Frank let his friends and acquaintances travel free of charge, and the money he collected rarely matched the tally of tickets sold. He tried explaining to one inspector that, statistically, on average, over time, the mistakes would even out and his takings would match the machine. The inspector was impressed and said, 'You're probably right, but until that happens we'll just keep on taking any shortfall out of your wages'. I'm not sure I ever believed Frank's claim that on two separate occasions, instead of drawing wages, he had to pay the Tramways Corporation.

When Frank finished his PhD he didn't have to do National Service because the medical examiner happened to be Frank's GP who warned him that any sudden increase in weight would be grounds for an exemption. Frank happily ate his way from 10 stones something to 13 stones something more in no time at all. The only problem was that he found that reinforcing too, and didn't stop there, so for most of the next quarter century Frank was physically as well as psychologically larger than life. Frank's first job as a psychologist was a six-month spell in Sheffield, where he was a trainee clinical psychologist. What would have happened if Frank 
had stayed as a clinical psychologist I cannot imagine! He would probably have invented Humour Therapy which would be like Aromatherapy with jokes instead of smells. After Sheffield, Frank went to Indiana University before being appointed to a lectureship at Adelaide. His association with Indiana continued throughout the years and he made frequent return visits on study leave usually via the three great metropolises Athens, Rome and Aberdeen.

Frank's humour was sorely tested by his illness, but it never left him. At St Andrews when they were taking a record of his illnesses he mentioned he had a burn on his foot and a broken tooth, hence, he had Foot and Mouth. Or, when his hair started to grow back after chemotherapy, I said, 'Your hair is growing back curly, Frank'. One of his lady helpers, Trisha, appeared and Frank said, 'My hair's growing back curly'. Trisha came and looked and said, 'It's not'. To which Frank replied, 'But it will when it gets to the bend!' Later, in College Grove, when one of the nurses was urging him to relax and asked, 'Are you able to relax?' his response was, 'Well, it got me through school'. It was also while Frank was in College Grove that I took some of his magazines to him and I noticed that he received, not one, but two copies of Choice. So, I asked him, 'Why do you get two copies of Choice?' His reply was, 'You need two to have choice!'

Frank amused and entertained everyone, but he was also very well informed on many subjects from Ancient History to Current Affairs, and that combination meant that Frank was always good company whether he was being funny or serious. He was always interesting and never dull, and we will miss him.

Following the departure of Malcolm Jeeves, three more lecturers were appointed by Alan Welford. First, John Brebner was appointed in 1969. Brebner, an Aberdeen graduate, had been lecturing at the University of Dundee and his main teaching and research interests were in personality theory, environmental psychology and ergonomics, the last being mainly taught within the Master of Applied Psychology degree. Brebner was later to play an important administrative role within the department and the faculty, becoming dean of the Faculty of Arts in the late 1980s. As dean he assisted in the establishment of the Bedford Industries research fellowship (see Chapter Four). At around the time of his retirement, he was responsible for bringing the biennial conference of the International Society for the Study of Individual Differences to Adelaide in 2005 - the first time the society had met in the southern hemisphere.

John Kaye, a clinical psychologist from South Africa, was appointed as a lecturer in 1972. In 1975, John Michael (Mike) Innes was appointed. Innes, a social psychologist, was promoted to reader in 1981 before leaving in 1991 to take the inaugural chair of psychology, heading the School of Psychology and Sociology at James Cook University in 1991 and subsequently at Murdoch University. After that he became executive dean of the Faculty of Humanities and Social Sciences at the University of Adelaide, then pro vice-chancellor at Murdoch University. He is currently a professor in the School of Psychology at the Australian College of Applied Psychology, based in Sydney. 
Innes came from the University of Edinburgh. He was hired as a social psychologist, joining Ron Penny in the teaching of that discipline at undergraduate and honours level. He soon became involved in the teaching of applied social psychology in the Diploma of Applied Psychology, and this developed into the teaching of a longstanding course in the application of methodology in program evaluation and in the sociology of knowledge. He taught courses across many different areas in social psychology and diverged into political psychology, the sociology and history of psychology, and health psychology. He supervised thirty-three honours students and seventeen diploma students in that time and also seventeen PhD students, including Bob Lange, Mark Herbett, Bernard Guerin, Christina Lee, Mary Katsikitis and Martha Augoustinos. He also managed several large government grants awarded for research in the social psychology of attitude change and social influence.

The appointments of Ted Nettelbeck and Neil Kirby as tenured lecturers marked a departure from Malcolm Jeeves's usual practice of building a staff profile characterised by the recruitment of people from overseas or with overseas qualifications (for example, Don McNicol). Both Nettelbeck and Kirby were graduates of the department, completing honours in 1969 and going on to $\mathrm{PhD}$ studies while supported by first-year-psychology tutoring contracts that effectively guaranteed employment for the duration of their candidatures while providing sufficient time to pursue $\mathrm{PhD}$ studies. In 1972, a research fellowship was established on the initiative of Alan Welford in partnership with Bedford Industries in Panorama, an organisation that provided work training and independent living programs for people with a disability. Nettelbeck was appointed as the first fellow. His role was to provide input to assessment and training programs for Bedford, while maintaining a half-time commitment to the teaching programs of the department.

However, from the outset Neil Kirby showed a keen interest in becoming involved in disability training research, which led to the development of a long-term, fruitful research collaboration that was to shape both of their careers for many years. In 1974, Nettelbeck was appointed to a tenured position as lecturer, initially to build staff responsible for developing the Diploma in Applied Psychology, a new fourth-year program promoted by Alan Welford as an alternative to the honours year for those students seeking an immediate pathway into employment as a psychologist. Kirby was appointed to the Bedford fellowship, a position that he held with distinction until 1983, when he transferred into the department as a full-time senior lecturer. Nettelbeck's entire career was spent in the department/school until his retirement towards the end of 2014 .

\section{Tenured women academics}

The first tenured female academic to be appointed was Inara Proske. Proske was promoted to the rank of senior tutor in 1974 , a teaching-only position, but was unable 
to obtain a lecturing (Level B) position for many years because of her decision (for family reasons) not to enrol for a PhD. Proske was highly respected by her colleagues and much loved by her students. She died tragically in 2000 at the age of fifty-six.

Martha Augoustinos was the first woman to be appointed to a tenured lectureship in 1993, followed by Jane Mathias, Amanda LeCouteur and Lynn Ward in 1994.

\section{Professional staff}

It is timely here also to record that the department/school has, since Malcolm Jeeves's years, been extremely well served by a legion of office staff not acknowledged elsewhere in this account but without the dedicated assistance of whom the department could not have functioned so effectively. Margaret Bruce was first appointed as Professor Jeeves's secretary, and after his departure she continued in a similar role to Jeeves's successors for some years. Margaret Blaber, who followed as the departmental secretary, was much loved by staff and students but particularly by the many $\mathrm{PhD}$ students whose theses she prepared for examination (original + three carbon copies) in the days before word processors became available. Others who served across the years in the general office were Tania Clarke, Jorja Denton, Sandy Elborough, Judy Fallon, Janet Hamilton, Hilary Horden, Judi Hurley, Carmel Jones, Pacquita Kennett, Helen Mensforth, Amira Mikhail, Sandra Naish, Martin Prokopiak, Wanda Prokopiak and Jenny Welsh.

\section{Departmental government}

Throughout the 1960s, there had been moves to democratise the university. Sparked by revolutionary students who demanded representation on university committees, members of the academic staff campaigned for the replacement of appointed 'god professors' as heads of departments with elected chairmen. Following pressure from the Staff Association, the university council decided in 1969 that, in the future, appointed professorial heads would be replaced by chairs whose appointments would follow elections involving all tenured staff. Although not technically elected, any member of the academic staff of the rank of senior lecturer (Level C) or above who was elected with a two-thirds majority of the votes would normally be appointed for a three-year term of office. Alan Welford was the last of the non-elected professorial heads. The previous system of appointed professorial heads was not restored until the appointment of John Taplin in 2000. Table 2.1 lists all heads/chairs who served from 1956 until 1999.

A further major development affecting the school was its transfer from the Faculty of Arts to the Faculty of Health Sciences in 1997. As a single-discipline school within the faculty, it now enjoys greater autonomy than most of the other schools. Over the years, three members of the school had served as deans of the Faculty of Arts: Malcolm Jeeves, Tony Winefield and John Brebner. Later, Mike Innes returned to the university as executive dean of the Faculty of Humanities and Social Sciences. 
Table 2.1 Appointed heads and elected chairs from 1956 to 2000.

Source: Author's own work.

\begin{tabular}{ll} 
Name & Duration \\
\hline Dr Arthur Meadows (appointed) & $1956-59$ \\
\hline Professor Malcolm Jeeves (appointed) & $1959-69$ \\
\hline Professor Alan Welford (appointed) & $1969-74$ \\
\hline Professor Alan Welford (elected) & 1975 \\
\hline Professor Ian John (elected) & $1975-76$ \\
\hline Dr Tony Winefield (elected) & $1977-78$ \\
\hline Mr Chris Cooper (elected) & $1979-87$ \\
\hline Dr Eric Rump (elected) & $1988-90$ \\
\hline A/Professor John Brebner (elected) & 1991 \\
\hline Mr Chris Cooper (elected) & $1992-99$
\end{tabular}

New academic appointments

Academic promotions

Until 1980, academic promotion was limited to senior lecturer (Level C), the so-called career grade. In 1980, promotion to reader (Level D) was introduced, but not until 1998 was it possible to be promoted to professor (Level E). Before that, every three years the university would call for appointment to two or three personal chairs.

In 1980, Dr Douglas Vickers was promoted to reader, and shortly afterwards Mike Innes, Tony Winefield, John Brebner and Theodore (Ted) Nettelbeck were also promoted to readerships (later renamed associate professorships).

\section{Undergraduate teaching}

Because of some objections within the Faculty of Science, psychology was not permitted to be taught as a first-year subject. Instead, Psychology $1 S$ was accepted as a second-year subject and Psychology $2 \mathrm{~S}$ as a third-year subject. However, science graduates who had passed $1 S$ and $2 S$ were accepted into honours.

In the Faculty of Arts there were two first-year subjects: Psychology 1 and Psychology 1A. Students completing Psychology 1A did not do the practical work included in Psychology 1 and were not permitted to enrol in second-year psychology. 
There were two second-year subjects: Psychology 2A (experimental psychology) and Psychology 2B (developmental psychology) and two third-year subjects: Psychology 3A (experimental psychology) and Psychology 3B (social psychology). In order to enrol in honours psychology, Faculty of Arts students had to complete a double major (that is, both second-year subjects and both third-year subjects). As a consequence, the honours class was very small until the end of the 1960s, with numbers ranging from two to five students. By the end of the 1960s, these requirements were abolished. Psychology was accepted by the Faculty of Science as a first-year subject, and in the Faculty of Arts Psychology 1A was abolished and the two second-year subjects were replaced by a single subject, Psychology 2, while the two third-year subjects were replaced by a single subject, Psychology 3 . This led to an enormous increase in honours enrolments, with more than twenty students per annum thereafter.

\section{Postgraduate training}

Following the enactment of the Psychological Practices Act 1973 (SA) and similar external pressure from bodies such as the Australian Psychological Society [APS], schools of psychology were expected to provide professional training that met certain criteria (see Chapter Four). Students who had completed an honours degree in psychology as well as a $\mathrm{PhD}$ could not become registered under the Act, and were therefore not permitted to call themselves psychologists, or to practise psychology. In order to register as a psychologist, psychology students had to complete an honours degree and then undergo two years of approved supervision by a registered psychologist, or else they had to complete an honours degree followed by an approved professional diploma or master's degree. As the number of APS colleges increased to nine (see Chapter Four), there was increased pressure to offer professional master's courses in areas such as clinical psychology, organisational psychology, and health psychology. These three professional programs are currently being offered at the University of Adelaide (as well as combined $\mathrm{PhD} /$ master's programs), although Flinders University and UniSA now only offer a clinical program.

\section{Research}

\section{Research input and output}

Ian John completed a PhD (1967) in the area of experimental psychophysics under the supervision of Professors Malcolm Jeeves and Ken Provins. His research activities in this field continued until 1979 when, following a year's study leave in the UK and Europe, he became interested in the critical examination of the philosophical, methodological and ideological bases of the discipline. From that point on, his primary research interests centred on meta-theoretical questions about the nature, production and application of psychological knowledge. 
During the 1980s and 1990s, John published a series of influential papers in the Australian Psychologist (see below). These papers critically examined epistemological issues in the production of psychological knowledge and the nature of the scientist-practitioner model, which had come to dominate the training of clinical practitioners in the field. John's work became increasingly influenced by the social constructionist movement in psychology and in particular by critical theorists such as Ken Gergen, Edward Sampson and Michael Billig. His enthusiasm for these revolutionary ideas, which questioned the claims of objectivity and neutrality upon which the discipline of psychology had been built, led to the establishment of the 'Meta-theory Discussion Group' which met every week within the Department of Psychology to discuss the implications and limits of these radical ideas. These became lively and scholarly debating forums between traditional experimentalists and a small number of younger academics and postgraduates who were enthusiastically embracing the 'critical turn' in psychology.

Peter Glow became interested in a form of 'intrinsic reinforcement', which assumes that animals (for example, rats) find control over their environment reinforcing. This notion overlaps with that of learned helplessness, which assumes that animals can learn that environmental events are not contingent on their behaviour (that is, that environmental events are uncontrollable). Learning this results in cognitive and motivational deficits that can transfer, inappropriately, to new situations in which events are controllable. In collaboration with Tony Winefield, who had become interested in learned helplessness, he won an ARC (then ARCG) grant and they published several joint papers. Peter Glow retired in 1992 after having served as chair of the University Education Committee (now renamed the Academic Board) but remains an emeritus professor in the school.

Tony Winefield and Marika Tiggemann also received significant funding from the ARC for their research on human helplessness and from the NHMRC for their longitudinal study on youth unemployment. These resulted in more than forty joint refereed journal articles and the book Growing up with unemployment: A longitudinal study of its psychological impact (1993).

\section{Research education}

Table 2.2 (overleaf) lists all PhD completions in the school until 1999. 
Table 2.2 PhD completions up to 1999.

Source: Author's own work.

\begin{tabular}{|c|c|c|c|}
\hline Year & Name & Title & Supervisor \\
\hline 1961 & $\begin{array}{l}\text { Sydney Harold } \\
\text { Lovibond }\end{array}$ & $\begin{array}{l}\text { Theory and method of conditioning } \\
\text { in relation to enuresis and its } \\
\text { treatment }\end{array}$ & Malcolm Jeeves \\
\hline 1966 & $\begin{array}{l}\text { Alan James } \\
\text { Richardson }\end{array}$ & $\begin{array}{l}\text { The effects of reduced cholinesterase } \\
\text { activity on discriminative behaviour } \\
\text { in the rat }\end{array}$ & Peter Glow \\
\hline 1967 & Ian David John & $\begin{array}{l}\text { An experimental investigation } \\
\text { of some aspects of sensory } \\
\text { discrimination }\end{array}$ & $\begin{array}{l}\text { Malcolm } \\
\text { Jeeves and Ken } \\
\text { Provins }\end{array}$ \\
\hline 1968 & Francis Ledwith & $\begin{array}{l}\text { The effects of hypoxia on } \\
\text { performance }\end{array}$ & Malcolm Jeeves \\
\hline 1969 & Leo Sosula & $\begin{array}{l}\text { The structure and function of the rat } \\
\text { retina with particular reference to } \\
\text { the acetylcholinesterase system in the } \\
\text { inner plexiform layer }\end{array}$ & Peter Glow \\
\hline 1969 & $\begin{array}{l}\text { Peter Simon } \\
\text { Delin }\end{array}$ & $\begin{array}{l}\text { An experimental study of mnemonic } \\
\text { devices in verbal learning }\end{array}$ & $\begin{array}{l}\text { Malcolm Jeeves } \\
\text { and Frank } \\
\text { Dalziel }\end{array}$ \\
\hline 1970 & $\begin{array}{l}\text { Irene Isobel } \\
\text { Holloway }\end{array}$ & $\begin{array}{l}\text { Some psychological concomitants of } \\
\text { addiction }\end{array}$ & Glen Mulligan \\
\hline 1971 & $\begin{array}{l}\text { Denis John } \\
\text { Glencross }\end{array}$ & Effector organisation in a motor skill & Alan Welford \\
\hline 1971 & Alan Russell & $\begin{array}{l}\text { An analysis of response-contingent } \\
\text { light change reinforcement }\end{array}$ & Peter Glow \\
\hline 1971 & $\begin{array}{l}\text { John Eaton } \\
\text { Taplin }\end{array}$ & $\begin{array}{l}\text { An experimental study of human } \\
\text { reasoning and conceptual behaviour }\end{array}$ & $\begin{array}{l}\text { Malcolm Jeeves, } \\
\text { Don McNicol } \\
\text { and Ian John }\end{array}$ \\
\hline 1972 & Leon C Lack & $\begin{array}{l}\text { Experiments in the control of } \\
\text { binocular rivalry }\end{array}$ & $\begin{array}{l}\text { Don McNicol } \\
\text { and John } \\
\text { Brebner }\end{array}$ \\
\hline
\end{tabular}




\begin{tabular}{|c|c|c|c|}
\hline 1972 & John Sweller & $\begin{array}{l}\text { Effects of initial discrimination } \\
\text { training on subsequent shift learning } \\
\text { in animals and humans }\end{array}$ & Tony Winefield \\
\hline 1973 & $\begin{array}{l}\text { Helen Russell } \\
\text { Winefield }\end{array}$ & $\begin{array}{l}\text { Operant remedial techniques with } \\
\text { reading retardation in children }\end{array}$ & Frank Dalziel \\
\hline 1973 & $\begin{array}{l}\text { Neil Harvey } \\
\text { Kirby }\end{array}$ & $\begin{array}{l}\text { Sequential effects in serial reaction } \\
\text { time }\end{array}$ & Alan Welford \\
\hline 1973 & $\begin{array}{l}\text { Theodore John } \\
\text { Nettelbeck }\end{array}$ & $\begin{array}{l}\text { An experimental investigation of } \\
\text { some parameters affecting differences } \\
\text { in perception }\end{array}$ & Doug Vickers \\
\hline 1974 & $\begin{array}{l}\text { Peter Thomson } \\
\text { Cairney }\end{array}$ & $\begin{array}{l}\text { Selective attention, order judgement } \\
\text { and the prior entry hypothesis }\end{array}$ & John Brebner \\
\hline 1974 & $\begin{array}{l}\text { Gerald Patrick } \\
\text { Mullins }\end{array}$ & $\begin{array}{l}\text { The effect of frustration and } \\
\text { uncertainty on discrimination and } \\
\text { learning }\end{array}$ & Tony Winefield \\
\hline 1976 & $\begin{array}{l}\text { Neil Douglas } \\
\text { Brewer }\end{array}$ & $\begin{array}{l}\text { Intellectual retardation and } \\
\text { parameters of choice reaction time }\end{array}$ & Ted Nettelbeck \\
\hline 1978 & Brian Johnston & $\begin{array}{l}\text { The relationship between } \\
\text { understanding the other's point of } \\
\text { view and effectiveness in education } \\
\text { groups }\end{array}$ & $\begin{array}{l}\text { Eric Rump and } \\
\text { John Brebner }\end{array}$ \\
\hline 1978 & $\begin{array}{l}\text { Peter Edwin } \\
\text { Hornsby }\end{array}$ & $\begin{array}{l}\text { Factors affecting the realisation of } \\
\text { prior expectations amongst British } \\
\text { migrants coming to Australia, } 1978\end{array}$ & Alan Welford \\
\hline 1978 & $\begin{array}{l}\text { Michael Robert } \\
\text { Lally }\end{array}$ & $\begin{array}{l}\text { Studies on sensory motor } \\
\text { performance and mental handicap }\end{array}$ & Ted Nettelbeck \\
\hline 1978 & Glen A Smith & $\begin{array}{l}\text { Studies of compatibility and } \\
\text { investigations of a model of reaction } \\
\text { time }\end{array}$ & $\begin{array}{l}\text { Alan Welford } \\
\text { and John } \\
\text { Brebner }\end{array}$ \\
\hline 1979 & $\begin{array}{l}\text { Judith Ann } \\
\text { Bowey }\end{array}$ & $\begin{array}{l}\text { Aspects of language processing in the } \\
\text { oral reading of third, fourth, and fifth } \\
\text { grade children }\end{array}$ & Ian John \\
\hline
\end{tabular}




\begin{tabular}{|c|c|c|c|}
\hline 1979 & Jason M White & $\begin{array}{l}\text { Operant behaviour: Interactions in } \\
\text { multi-operant schedules }\end{array}$ & Frank Dalziel \\
\hline 1979 & $\begin{array}{l}\text { Roslyn Ann } \\
\text { Glow }\end{array}$ & $\begin{array}{l}\text { The measurement of teacher and } \\
\text { parent perceived hyperkinetic impulse } \\
\text { disorder }\end{array}$ & $\begin{array}{l}\text { Peter Glow and } \\
\text { Eric Rump }\end{array}$ \\
\hline 1979 & $\begin{array}{l}\text { Jacques } \\
\text { Christoph } \\
\text { Metzer }\end{array}$ & $\begin{array}{l}\text { Social, personality and arousal } \\
\text { variables affecting measures of } \\
\text { performance in humans and animals }\end{array}$ & Frank Dalziel \\
\hline 1979 & $\begin{array}{l}\text { Eric Edward } \\
\text { Rump }\end{array}$ & $\begin{array}{l}\text { Divergent thinking, aesthetic } \\
\text { preferences, and orientation towards } \\
\text { arts and science }\end{array}$ & $\begin{array}{l}\text { Alan Welford } \\
\text { and Tony } \\
\text { Winefield }\end{array}$ \\
\hline 1980 & $\begin{array}{l}\text { Patricia Anne } \\
\text { Quealey }\end{array}$ & $\begin{array}{l}\text { An experimental study of mental } \\
\text { imagery }\end{array}$ & Peter Delin \\
\hline 1980 & $\begin{array}{l}\text { Leonie Kay } \\
\text { Waters }\end{array}$ & $\begin{array}{l}\text { Social reinforcement of the work } \\
\text { behaviour of retardates and normals }\end{array}$ & Frank Dalziel \\
\hline 1980 & $\begin{array}{l}\text { Marika } \\
\text { Tiggemann }\end{array}$ & $\begin{array}{l}\text { An experimental investigation of the } \\
\text { learned helplessness effect in humans }\end{array}$ & Tony Winefield \\
\hline 1981 & Colleen Phillips & $\begin{array}{l}\text { Mental retardation and the } \\
\text { development of recognition memory }\end{array}$ & Ted Nettelbeck \\
\hline 1982 & $\begin{array}{l}\text { Robert Victor } \\
\text { Lange }\end{array}$ & $\begin{array}{l}\text { Cognitive and behavioural } \\
\text { impulsivity among prisoners and } \\
\text { comparison groups }\end{array}$ & $\begin{array}{l}\text { Mike Innes and } \\
\text { Peter Glow }\end{array}$ \\
\hline 1982 & Jeffrey Bollard & $\begin{array}{l}\text { A systematic modification of dry- } \\
\text { bed training for the treatment of } \\
\text { nocturnal enuresis }\end{array}$ & Ted Nettelbeck \\
\hline 1982 & $\begin{array}{l}\text { Suzanne } \\
\text { Bettison }\end{array}$ & $\begin{array}{l}\text { A comparison of toilet training } \\
\text { strategies for the retarded }\end{array}$ & $\begin{array}{l}\text { Eric Rump and } \\
\text { Ted Nettelbeck }\end{array}$ \\
\hline 1982 & Gary H Childs & $\begin{array}{l}\text { Social cognition skills and their } \\
\text { behavioural correlates in school age } \\
\text { children }\end{array}$ & $\begin{array}{l}\text { Ron Penny and } \\
\text { Peter Delin }\end{array}$ \\
\hline 1982 & Stanley Salagaras & $\begin{array}{l}\text { Adaptive behaviour of mentally } \\
\text { retarded persons within education } \\
\text { and activity settings }\end{array}$ & Ted Nettelbeck \\
\hline
\end{tabular}




\begin{tabular}{|c|c|c|c|}
\hline 1983 & $\begin{array}{l}\text { James Norman } \\
\text { Leary }\end{array}$ & $\begin{array}{l}\text { Adaptation of decision criteria in } \\
\text { vigilance tasks }\end{array}$ & Doug Vickers \\
\hline 1983 & Christina Lee & $\begin{array}{l}\text { Conceptual and methodological } \\
\text { issues in self-efficacy theory }\end{array}$ & Mike Innes \\
\hline 1983 & $\begin{array}{l}\text { Elizabeth } \\
\text { Jardine }\end{array}$ & $\begin{array}{l}\text { Psychological and psychosociological } \\
\text { aspects of depression }\end{array}$ & Tony Winefield \\
\hline 1984 & $\begin{array}{l}\text { Richard Mark } \\
\text { Herbett }\end{array}$ & $\begin{array}{l}\text { The Type A coronory-prone } \\
\text { behaviour pattern, self-awareness and } \\
\text { standards for performance }\end{array}$ & Mike Innes \\
\hline 1984 & Bernard Guerin & $\begin{array}{l}\text { Mere presence and conformity effects } \\
\text { in social facilitation }\end{array}$ & Mike Innes \\
\hline 1984 & Jeanette Packer & $\begin{array}{l}\text { Performance changes in perceptual } \\
\text { discrimination and identification }\end{array}$ & Doug Vickers \\
\hline 1984 & Philip Smith & $\begin{array}{l}\text { Cognitive control in human } \\
\text { information processing }\end{array}$ & Doug Vickers \\
\hline 1984 & $\begin{array}{l}\text { Carlene June } \\
\text { Wilson }\end{array}$ & $\begin{array}{l}\text { Developmental studies in timed } \\
\text { performance }\end{array}$ & Ted Nettelbeck \\
\hline 1985 & James G Barber & $\begin{array}{l}\text { Competing accounts of the learned } \\
\text { helplessness effect in humans }\end{array}$ & Tony Winefield \\
\hline 1985 & Mara Olekalns & $\begin{array}{l}\text { The representation of places: } \\
\text { Idiographic and nomothetic } \\
\text { explorations of environmental } \\
\text { perception and behaviour }\end{array}$ & John Brebner \\
\hline 1985 & $\begin{array}{l}\text { Leonard Jack } \\
\text { White }\end{array}$ & $\begin{array}{l}\text { Coding and processing numerical } \\
\text { information }\end{array}$ & $\begin{array}{l}\text { Peter Delin and } \\
\text { Chris Cooper }\end{array}$ \\
\hline 1988 & $\begin{array}{l}\text { Oksana T } \\
\text { Holubowycz }\end{array}$ & $\begin{array}{l}\text { An Australian study of alcohol } \\
\text { dependence in women: The } \\
\text { significance of sex role identity, life } \\
\text { event stress, social support, and other } \\
\text { factors }\end{array}$ & Mike Innes \\
\hline 1988 & $\begin{array}{l}\text { Andrew Neil } \\
\text { Kenner }\end{array}$ & $\begin{array}{l}\text { Consistencies in body-focused hand } \\
\text { movements }\end{array}$ & $\begin{array}{l}\text { Peter Delin and } \\
\text { Frank Dalziel }\end{array}$ \\
\hline
\end{tabular}




\begin{tabular}{|c|c|c|c|}
\hline 1988 & $\begin{array}{l}\text { Catherine } \\
\text { Richmond Delin }\end{array}$ & $\begin{array}{l}\text { An investigation into the differential } \\
\text { effects of the varieties of praise }\end{array}$ & $\begin{array}{l}\text { Mike Innes and } \\
\text { Frank Dalziel }\end{array}$ \\
\hline 1989 & $\begin{array}{l}\text { Sandra J } \\
\text { Neuling }\end{array}$ & $\begin{array}{l}\text { Psychosocial needs and responses in } \\
\text { breast cancer recovery }\end{array}$ & $\begin{array}{l}\text { Tony Winefield } \\
\text { and Helen } \\
\text { Winefield }\end{array}$ \\
\hline 1989 & Lina Ricciardelli & $\begin{array}{l}\text { Childhood bilingualism, } \\
\text { metalinguistic awareness and } \\
\text { creativity }\end{array}$ & Eric Rump \\
\hline 1990 & $\begin{array}{l}\text { Jane Leanne } \\
\text { Mathias }\end{array}$ & $\begin{array}{l}\text { Social intelligence and personal } \\
\text { competence in mentally retarded } \\
\text { adolescents }\end{array}$ & Ted Nettelbeck \\
\hline 1991 & $\begin{array}{l}\text { Thomas } \\
\text { Raymond Smyth }\end{array}$ & $\begin{array}{l}\text { Impaired motor skill and perception } \\
\text { in children }\end{array}$ & Ted Nettelbeck \\
\hline 1991 & $\begin{array}{l}\text { Martha } \\
\text { Augoustinos }\end{array}$ & $\begin{array}{l}\text { Social representations and social } \\
\text { cognition: A convergence of different } \\
\text { traditions }\end{array}$ & Mike Innes \\
\hline 1991 & $\begin{array}{l}\text { Elizabeth } \\
\text { Foreman }\end{array}$ & $\begin{array}{l}\text { Individual differences in expanded } \\
\text { judgement tasks }\end{array}$ & Doug Vickers \\
\hline 1991 & $\begin{array}{l}\text { Andrew Leigh } \\
\text { Gilbert }\end{array}$ & $\begin{array}{l}\text { Medication use among the elderly: } \\
\text { Psychological, pharmacological and } \\
\text { public health perspectives }\end{array}$ & Mike Innes \\
\hline 1992 & $\begin{array}{l}\text { Felicity C } \\
\text { Forster }\end{array}$ & $\begin{array}{l}\text { Exploration in the rat and the } \\
\text { marmoset: Relationships between } \\
\text { learning and object novelty in an } \\
\text { open field }\end{array}$ & Frank Dalziel \\
\hline 1993 & $\begin{array}{l}\text { Philip Benjamin } \\
\text { Mohr }\end{array}$ & $\begin{array}{l}\text { Reconciling the roles of status and } \\
\text { behaviour in group influence: Toward } \\
\text { a status-confirmation model }\end{array}$ & Peter Delin \\
\hline 1993 & $\begin{array}{l}\text { Stephen Lloyd } \\
\text { Brown }\end{array}$ & $\begin{array}{l}\text { Reducing community smoking } \\
\text { prevalence: A behavioural } \\
\text { epidemiologic perspective }\end{array}$ & Neville Owen \\
\hline 1994 & Lynn Ward & $\begin{array}{l}\text { Changes in the elderly in speed } \\
\text { of processing, internal noise and } \\
\text { cognitive functioning }\end{array}$ & Ted Nettelbeck \\
\hline
\end{tabular}




\begin{tabular}{|c|c|c|c|}
\hline 1994 & Greg Evans & $\begin{array}{l}\text { Concurrent processing of visual and } \\
\text { auditory information: An assessment } \\
\text { of parallel versus sequential } \\
\text { processing models }\end{array}$ & Ted Nettelbeck \\
\hline 1994 & Con KK Stough & $\begin{array}{l}\text { Analysis of methodological variables } \\
\text { underlying correlations between } \\
\text { elementary cognitive tasks }\end{array}$ & Ted Nettelbeck \\
\hline 1995 & Eugene Hejka & $\begin{array}{l}\text { The effects of stimulus intensity } \\
\text { and task complexity on learned } \\
\text { helplessness in humans }\end{array}$ & Tony Winefield \\
\hline 1995 & Robyn Young & $\begin{array}{l}\text { Savant syndrome: Process underlying } \\
\text { extraordinary abilities }\end{array}$ & Ted Nettelbeck \\
\hline 1996 & $\begin{array}{l}\text { Maureen } \\
\text { Frances Dollard }\end{array}$ & $\begin{array}{l}\text { Work stress: Conceptualisations } \\
\text { and implications for research } \\
\text { methodology and workplace } \\
\text { intervention }\end{array}$ & Tony Winefield \\
\hline 1996 & $\begin{array}{l}\text { Amanda Jane } \\
\text { LeCouteur }\end{array}$ & $\begin{array}{l}\text { Indirectness and politeness } \\
\text { in requesting: An analysis of } \\
\text { sociolinguistic and pragmatic aspects } \\
\text { in an Australian context }\end{array}$ & Peter Delin \\
\hline 1996 & $\begin{array}{l}\text { Michael Stephen } \\
\text { Clark }\end{array}$ & $\begin{array}{l}\text { Psychological determinants of } \\
\text { outcome following rehabilitation } \\
\text { from stroke }\end{array}$ & Ted Nettelbeck \\
\hline 1996 & $\begin{array}{l}\text { Jane Suzanne } \\
\text { Blake-Mortimer }\end{array}$ & $\begin{array}{l}\text { Lymphocytic 5'-ectonucleotidase: } \\
\text { A marker of psychological stress- } \\
\text { induced immune suppression }\end{array}$ & Tony Winefield \\
\hline 1997 & Karen Beck & $\begin{array}{l}\text { The development of affective } \\
\text { organisational commitment }\end{array}$ & Carlene Wilson \\
\hline 1997 & $\begin{array}{l}\text { Michael David } \\
\text { Lee }\end{array}$ & $\begin{array}{l}\text { Connectionist learning of mental } \\
\text { representation }\end{array}$ & Doug Vickers \\
\hline 1997 & $\begin{array}{l}\text { Reza } \\
\text { Tasbihsazan } \\
\text { Mashhadi }\end{array}$ & $\begin{array}{l}\text { Prediction of later intelligence beyond } \\
2 \text { years of age from preference for } \\
\text { novelty during infancy }\end{array}$ & $\begin{array}{l}\text { Ted Nettelbeck } \\
\text { and Neil Kirby }\end{array}$ \\
\hline
\end{tabular}




\begin{tabular}{|c|c|c|c|}
\hline 1998 & $\begin{array}{l}\text { Paul Howard } \\
\text { Delfabbro }\end{array}$ & $\begin{array}{l}\text { A psychological investigation } \\
\text { of gambling in South Australia } \\
\text { with particular reference to the } \\
\text { demographic, behavioural and } \\
\text { cognitive factors underlying regular } \\
\text { poker/slot machine gambling }\end{array}$ & Tony Winefield \\
\hline 1998 & $\begin{array}{l}\text { Helen Lestelle } \\
\text { Mensforth }\end{array}$ & $\begin{array}{l}\text { An examination of different } \\
\text { explanations of gender differences in } \\
\text { depression using a sample of midlife } \\
\text { women }\end{array}$ & $\begin{array}{l}\text { Ian John and } \\
\text { Don Pritchard }\end{array}$ \\
\hline 1998 & Vanessa Mills & $\begin{array}{l}\text { Applying ecological learning theory } \\
\text { to the conservation of behaviour of } \\
\text { species housed in a zoo environment: } \\
\text { An empirical examination }\end{array}$ & Frank Dalziel \\
\hline 1998 & $\begin{array}{l}\text { Miriam } \\
\text { Elizabeth Hill }\end{array}$ & $\begin{array}{l}\text { Sterotypes, prejudice and prejudice } \\
\text { reduction }\end{array}$ & $\begin{array}{l}\text { Martha } \\
\text { Augoustinos }\end{array}$ \\
\hline 1998 & $\begin{array}{l}\text { Nicholas Ralph } \\
\text { Burns }\end{array}$ & $\begin{array}{l}\text { Inspection time and cognitive } \\
\text { abilities: An event-related potential } \\
\text { study }\end{array}$ & $\begin{array}{l}\text { Ted Nettelbeck } \\
\text { and Chris } \\
\text { Cooper }\end{array}$ \\
\hline 1999 & $\begin{array}{l}\text { Philip } \\
\text { Chittleborough }\end{array}$ & $\begin{array}{l}\text { Psychological perspectives on the } \\
\text { perception, appraisal, and production } \\
\text { of everyday argument }\end{array}$ & Peter Delin \\
\hline 1999 & Alexander Ask & $\begin{array}{l}\text { To kill or not to kill: Competition, } \\
\text { aggression, and videogames, in } \\
\text { adolescents }\end{array}$ & $\begin{array}{l}\text { Martha } \\
\text { Augoustinos } \\
\text { and Tony } \\
\text { Winefield }\end{array}$ \\
\hline 1999 & $\begin{array}{l}\text { Andrew } \\
\text { McDowell }\end{array}$ & $\begin{array}{l}\text { The relationship between research } \\
\text { and practice in conflict resolution }\end{array}$ & Ian John \\
\hline
\end{tabular}




\section{Enriched by visiting scholars}

Jeeves has mentioned several overseas scholars who visited the school during his time at Adelaide. Until 1999, the school continued to attract overseas visitors. These included Professor Mel Marx from the University of Missouri in 1969; Professor Charles Spielberger from the University of Southern Florida; and Dr Michael Argyle, the famous social psychologist from Oxford University, who was awarded a DLitt degree by the University of Adelaide in 1982 (a higher doctorate awarded on the basis of published work).

Professor Neil O'Connor, who was director of a London-based MRC unit researching intellectual disability, also spent time here in 1983. His visit was supported by Faculty of Arts funding. Professor Patrick Rabbitt, who was director of the Cognitive Ageing Unit at Manchester University, visited in 1988, again under Arts funding; and Mike Anderson, who was at that time at the University of Western Australia in psychology and responsible for a large ARC project about childhood cognitive development which supported a Neurocognitive Development Unit there, visited in both 1991 and 1999. Other visitors included Dr Catalina Ramis from Spain in 1990; Dr Mary Pickersgill from the University of London (a former colleague of Jeeves's) in 1993; Dr David Fryer from the University of Stirling in Scotland in 1996; Professor Florence Denmark, Robert Scott Pace distinguished professor and chair of psychology from Pace University, New York, in 1996; Professor James Barber, head of social administration, Flinders University, in 1996; and Professors Urban Janlert and Anne Hammarström from Umea University in Sweden in 1999, both of whom had conducted extensive research on the psychological effects of unemployment, a topic which I had been researching with my former student, Marika Tiggemann, Helen Winefield and Bob Goldney.

In addition, Professor Arthur Jensen, from University of California Berkeley, well known for his controversial views on race and IQ, gave a lecture in 1998 that, unlike his interstate lectures, was not disrupted by rioting students, because, at the suggestion of vice-chancellor Don Stranks, he shared the platform with other scholars, including Professor Kevin Marjoribanks, who put forward an opposing view. Finally, in 1999, Professor Martin Seligman from the University of Pennsylvania visited and gave a public lecture. At the time, Seligman was famous for his research on learned helplessness, a topic on which I had researched with several of my $\mathrm{PhD}$ students. More recently, he has become even better known for his pioneering work on positive psychology, and he was a thinker-in-residence in 2012 under the state government's scheme, introduced by the then Premier Mike Rann in 2000.

Numerous Adelaide graduates who completed their degree up to 1999 have gone on to distinguished academic careers, as shown in Table 2.3 (overleaf). 
Table 2.3 Some distinguished Adelaide graduates.

Source: Author's own work.

\begin{tabular}{|c|c|c|c|}
\hline Name & Bachelor & $\mathrm{PhD}$ & Position attained \\
\hline Martha Augoustinos & Adelaide & Adelaide & $\begin{array}{l}\text { Professor of psychology, } \\
\text { University of Adelaide }\end{array}$ \\
\hline Jim Barber & Flinders & Adelaide & $\begin{array}{l}\text { Vice-chancellor, } \\
\text { University of New England }\end{array}$ \\
\hline Neil Brewer & Adelaide & Adelaide & $\begin{array}{l}\text { Professor of psychology, } \\
\text { Flinders University }\end{array}$ \\
\hline Nick Burns & Adelaide & Adelaide & $\begin{array}{l}\text { Professor of psychology, } \\
\text { University of Adelaide }\end{array}$ \\
\hline Don Byrne & Adelaide & Adelaide & $\begin{array}{l}\text { Professor of psychology, } \\
\text { Australian National University }\end{array}$ \\
\hline Anna Chur-Hansen & Adelaide & Adelaide & $\begin{array}{l}\text { Professor of psychology, } \\
\text { University of Adelaide }\end{array}$ \\
\hline Richard Clark & Adelaide & Adelaide & $\begin{array}{l}\text { Professor of psychology, } \\
\text { Flinders University }\end{array}$ \\
\hline Paul Delfabbro & Adelaide & Adelaide & $\begin{array}{l}\text { Professor of psychology, } \\
\text { University of Adelaide }\end{array}$ \\
\hline Maureen Dollard & Adelaide & Adelaide & $\begin{array}{l}\text { Professor of psychology, } \\
\text { University of South Australia }\end{array}$ \\
\hline Andrew Gilbert & Adelaide & Adelaide & $\begin{array}{l}\text { Professor of pharmacy, } \\
\text { University of South Australia }\end{array}$ \\
\hline Denis Glencross & UWA & Adelaide & $\begin{array}{l}\text { Professor of psychology, } \\
\text { Curtin University }\end{array}$ \\
\hline Bernard Guerin & Adelaide & Adelaide & $\begin{array}{l}\text { Professor of psychology, } \\
\text { University of South Australia }\end{array}$ \\
\hline Robert Harcourt & Adelaide & Cambridge & $\begin{array}{l}\text { Professor of marine biology, } \\
\text { Macquarie University }\end{array}$ \\
\hline Ian John & Adelaide & Adelaide & $\begin{array}{l}\text { Professor of psychology, } \\
\text { University of Adelaide }\end{array}$ \\
\hline
\end{tabular}




\begin{tabular}{|c|c|c|c|}
\hline Mary Katsikitis & Adelaide & Adelaide & $\begin{array}{l}\text { Professor of psychology, } \\
\text { University of Sunshine Coast }\end{array}$ \\
\hline Leon Lack & Stanford & Adelaide & $\begin{array}{l}\text { Professor of psychology, } \\
\text { Flinders University }\end{array}$ \\
\hline Christina Lee & Adelaide & Adelaide & $\begin{array}{l}\text { Professor of psychology, } \\
\text { University of Queensland }\end{array}$ \\
\hline Michael Lee & Adelaide & Adelaide & $\begin{array}{l}\text { Professor of cognitive sciences, } \\
\text { University C Irvine }\end{array}$ \\
\hline Syd Lovibond & Melbourne & Adelaide & $\begin{array}{l}\text { Professor of psychology, } \\
\text { University of New South Wales }\end{array}$ \\
\hline Jane Mathias & Adelaide & Adelaide & $\begin{array}{l}\text { Professor of psychology, } \\
\text { University of Adelaide }\end{array}$ \\
\hline Craig McGarty & Adelaide & Macquarie & $\begin{array}{l}\text { Professor of psychology, } \\
\text { University of Western Sydney }\end{array}$ \\
\hline Don McNicol & Adelaide & Cambridge & $\begin{array}{l}\text { Vice-chancellor, } \\
\text { University of Sydney }\end{array}$ \\
\hline Phil Mohr & Adelaide & Adelaide & $\begin{array}{l}\text { Professor of psychology, } \\
\text { University of Adelaide }\end{array}$ \\
\hline Ted Nettelbeck & Adelaide & Adelaide & $\begin{array}{l}\text { Professor of psychology, } \\
\text { University of Adelaide }\end{array}$ \\
\hline Mike Nicholls & Adelaide & Cambridge & $\begin{array}{l}\text { Professor of psychology, } \\
\text { Flinders University }\end{array}$ \\
\hline Mara Olekalns & Adelaide & Adelaide & $\begin{array}{l}\text { Professor of management, } \\
\text { University of Melbourne }\end{array}$ \\
\hline Candi Peterson & Adelaide & UCSB & $\begin{array}{l}\text { Professor of psychology, } \\
\text { University of Queensland }\end{array}$ \\
\hline Lina Ricciardelli & Adelaide & Adelaide & $\begin{array}{l}\text { Professor of psychology, } \\
\text { Deakin University }\end{array}$ \\
\hline Ken Rigby & Adelaide & Adelaide & $\begin{array}{l}\text { Professor of education, } \\
\text { University of South Australia }\end{array}$ \\
\hline Philip Smith & Adelaide & Adelaide & $\begin{array}{l}\text { Professor of psychology, } \\
\text { University of Melbourne }\end{array}$ \\
\hline
\end{tabular}




\begin{tabular}{llll}
\hline Con Stough & Adelaide & Adelaide & $\begin{array}{l}\text { Professor of psychology, } \\
\text { Swinburne University }\end{array}$ \\
\hline John Sweller & Adelaide & Adelaide & $\begin{array}{l}\text { Professor of education, } \\
\text { University of New South Wales }\end{array}$ \\
\hline John Taplin & Adelaide & Adelaide & $\begin{array}{l}\text { Pro vice-chancellor, } \\
\text { University of Adelaide }\end{array}$ \\
\hline Marika Tiggemann & Adelaide & Adelaide & $\begin{array}{l}\text { Professor of psychology, } \\
\text { Flinders University }\end{array}$ \\
\hline Alec Wearing & Adelaide & Yale & $\begin{array}{l}\text { Professor of psychology, } \\
\text { University of Melbourne }\end{array}$ \\
\hline Jason White & Adelaide & Adelaide & $\begin{array}{l}\text { Professor of pharmacy, } \\
\text { University of South Australia }\end{array}$ \\
\hline Helen Winefield & Adelaide & Adelaide & $\begin{array}{l}\text { Professor of psychology, } \\
\text { University of Adelaide }\end{array}$ \\
\hline Carlene Wilson & Adelaide & Adelaide & $\begin{array}{l}\text { Professor of cancer prevention, } \\
\text { Flinders University }\end{array}$ \\
\hline
\end{tabular}

\section{Sporting history}

\section{Australian Rules Volleyball}

On a lighter note, in addition to its academic achievements, the school also boasts a proud and distinguished sporting history. It is the home of Australian Rules Volleyball [ARVB] which was established in 1963 by Syd Lovibond and Tony Winefield and, after fifty-two years and more than 2000 games, is still played on a weekly basis. Because the game was always played without an umpire, in the early days play was often delayed by lengthy disputes about whether the ball landed in or out and, where several players touched the net, who touched it first (see below). ARVB is an inclusive sport with the following hierarchy:

1. The Senior Commissioner (SC) (Tony Winefield)

2. Junior Commissioners (appointed from time to time by the SC)

3. Ordinary Players (OPs) 
4. Apprentice Players (APs)

5. Failed Players (FPs)

6. Lapsed Players (LPs).

Failed Players are those who have never played and Lapsed Players are those who have played but no longer do so.

\section{The 'rules'}

There are no rules - only conventions. In general, except where the SC intervenes directly and makes an unequivocal ex cathedra pronouncement, disputes are resolved in the following manner. Where no player concedes the point to the opposition, the point is replayed. Where a player concedes a point to the opposition the point will be so conceded. (Ideally, such disputes are conducted with ill will and petulance). As in orthodox volleyball, the ball can be played with any part of the body above the waist, although players aged seventy or more are permitted to use any part of the body. The score will be called by the server. The 'rules' concerning Netplay (defined as deliberately touching the net while the ball is in play) are obscure.

The ethos

ARVB differs from most sports in that the normal sporting etiquette concerning fair play, losing with grace and so on is not merely not observed, but is in fact actively discouraged. Instead, petulance, violence, gamesmanship and personal abuse are the qualities most admired and encouraged. Although points are sometimes won in the orthodox manner, more often they are won as a result of misleading calls, such as 'Mine!', 'Out!', 'Leave it!', or 'Let it go!'. Points won in such a manner are particularly satisfying because they lead to an unfortunate opponent being abused and ridiculed by his or her team-mates for gullibility and ineptness. In general, in addition to winning, the main purpose of the game is to infuriate and humiliate everyone else on court - team-mates and opponents alike culminating, ideally, in a walk-off (see below).

\section{The code of conduct}

Whilst gamesmanship, netplay and petulance are integral to Australian Rules Volleyball and are admired and encouraged, the following activities, 
which have infected, sullied and brought into disrepute other international sporting codes, are not, never have been and will not be, tolerated: ball tampering; betting against one's own team; accepting bribes to lose matches; match fixing; racially abusing an umpire, opponent, spectator or team-mate; deliberately injuring an umpire, opponent, spectator or team-mate; brawling, either on or off court; using performance-enhancing drugs.

The traditions

The walk-off. The supreme act of petulance is the walk-off. Walk-offs are much admired and can result in the immediate promotion of an apprentice player (AP) to the rank and status of full ordinary player (OP). Such a walk-off, however, would need to be preceded by an uncontrolled temper tantrum and occur during the course of a game. Simulated walk-offs, while admirable in themselves, cannot be expected to attract the highest commendation.

Weaking. The most common form of abuse is the cry of 'Weak!'. Indeed, it has become conventional for ARVB players to 'weak' one another whenever an opportunity arises. The right to 'weak' is strictly hierarchical. The Commissioners have unrestricted weaking rights, but ordinary players are not entitled to weak Commissioners, although they are free to weak one another, apprentice players, failed players and lapsed players. Similarly, apprentice players may only weak one another, failed players and lapsed players. Failed players may only weak one another and lapsed players. Finally, lapsed players may only weak one another.

\section{The annual staff-student soccer match}

Since the large increase in the number of honours students from the early 1970s, there has been an annual soccer match between the staff and postgraduate students versus the honours students. The teams compete for the highly coveted Winefield-Metzer Trophy. At least four members of each team must be female. The match is traditionally won by the staff, although a major upset occurred in 1995, when the honours students achieved a shock (and totally undeserved) victory. The staff retaliated with a record 6-0 win in 1996, reported in The Adelaidean on 22 April 1996 (Winefield, p. 8) as follows: 
Psychology students have no answers to Ask

A scintillating performance by postgraduate student Alex Ask who scored five goals enabled the postgraduate/staff team to cruise to a convincing 6-0 victory over the honours students in the psychology department annual soccer match. Smarting from last year's shock defeat, the staff team showed no mercy in a devastating display. After a relatively even first half, the introduction of wily defender Nettelbeck for a rapidly tiring Rump transformed the game. The staff ran riot in the second half netting four goals. Burns, Kennett, Tinsley and Cafarella were solid in defence and fended off some spirited student attacks led by Amos, with aplomb. Striker Ask was well supported by Metzer, Kirby, Hill, Winefield and Ward. The game was tightly controlled from the centre circle by Economics Department referee Hatch who awarded a penalty to each team and, in the spirit (and letter) of the law, sent off Hawkins late in the game following a second bookable offence (she had earlier received a yellow card for a brutal tackle on nimble winger Kirby).

\section{References}

Lovibond, SH, \& Lovibond, PF. (1995). Manual for the Depression Anxiety Stress Scales (2 ${ }^{\text {nd }}$ ed.). Sydney: Psychology Foundation.

Mackintosh, NJ. (1974). The psychology of animal learning. London: Academic Press.

Munn, NL. (1980). Being and becoming: An autobiography. Adelaide: Adelaide University Union Press.

Welford, AT. (1968). Fundamentals of skill. London: Methuen.

Winefield, T. (1996, 22 April). Psychology students have no answers to Ask. The Adelaidean, 8.

Winefield, AH, Tiggemann, M, Winefield, HR, \& Goldney, RD. (1993). Growing up with unemployment: A longitudinal study of its psychological impact. London: Routledge.

\section{Legislation}

Psychological Practices Act 1973 (SA). Retrieved from https://www.legislation.sa.gov.au/LZ/ C/A/PSYCHOLOGICAL\%20PRACTICES\%20ACT\%201973/2010.06.30/1974.37. UN.PDF. 


\section{Acknowledgements}

We wish to thank the following people, who have supplied invaluable information for both this chapter and the next: John Brebner; Andrew Cook, archives officer, University Archives \& Recordkeeping, the University of Adelaide; Maureen Bell, research librarian for psychiatry, psychology, public health, nursing and translational health science, Barr Smith Library, University of Adelaide. 


\title{
The later years
}

\author{
Anna Chur-Hansen
}

\section{0 and beyond}

John Eaton Taplin was the first external appointment to the position of chair of psychology at the University of Adelaide and head of the department since Alan Welford's appointment in 1969 as successor to Malcolm Jeeves. He was a graduate of the University of Adelaide (he had completed the BSc Honours degree in 1967, supervised by Ken Provins, and he had a PhD conferred in 1972, supervised first by Malcolm Jeeves, but followed by Don McNicol and Ian John when Jeeves moved to St Andrews). Moreover, he had earlier held temporary appointments in the department as technical and professional officer and as a tutor while enrolled in the PhD degree, supervised by Professor Jeeves. Beyond the award of his $\mathrm{PhD}$, he had gone on to complete postdoctoral studies at the University of Colorado in the US and taken up an assistant professorship at Claremont Graduate University in California, before returning in 1974 to the University of New South Wales, where he joined the academic staff in the school led by Professor Syd Lovibond, who had moved from the Adelaide department in 1969. Lovibond was committed to building a strong research-active school that would advance the evidence-based professional practice of psychology, and John Taplin's early career profile provided a good fit with these aims.

Taplin's move back to Adelaide from the beginning of 2000 marked a new phase for the department, which for some twenty years had functioned under a policy of governance by departmental committee convened by an elected chairperson, introduced by the university in 1974. His appointment was welcomed by current staff because he was seen as well qualified to lead the department at a time when the university was increasing expectations that all academic staff should be research-active. He had been a member of the editorial board of the prestigious Journal of Experimental 
Psychology: Human Learning and Memory and during his twenty-five years at the University of New South Wales had built an international reputation as a scholar and researcher. His theoretically based research interests in cognitive development during infancy and childhood and their application in the fields of developmental disabilities, the assessment and treatment of paediatric pain, and forensic psychology, had been supported almost continuously by ARC and NHMRC funding.

Moreover, it was obvious from the outset of his appointment to the chair and position as head in psychology at Adelaide that he was a strong strategic thinker who had a clear vision for how he expected the department to develop under his leadership. He brought exceptional energy to his new role of head, and he proved to be an excellent communicator who was inclusive with staff and students but also good at representing the department externally within the university, the Australian Psychological Society and the wider community.

\section{Background to Professor Taplin's appointment}

Professor Taplin's appointment was an immediate success, in part - but most importantly - because of the successful working relationship that he quickly established with Professor Derek Frewin, the executive dean of the Faculty of Health Sciences. It is important to note, however, that this outcome had been smoothed by the legacy of Christopher Cooper, who, with only short terms outside the role, had served as chairman of the department throughout most of the 1980s and 1990s. Dr Cooper was a medical graduate whose long-term interests in the brain had initially brought him into the department in 1961 to work with Malcolm Jeeves. This led subsequently to tenure as a lecturer. He lectured principally on brain structures and behavioural functions, although, like many others during the 1970s and 1980s, he also tried his hand at the thankless task of introducing statistics and methodology to introductory psychology students.

Towards the end of the 1990s, his position changed to head as a consequence of policy reforms introduced by Professor Mary O'Kane (vice-chancellor 1996-2001), as she sought to replace committee governance throughout the university with single executive control, whereby power was conferred downwards to leaders at lower structural levels of faculty and department. Although he regarded himself more as 'the servant of the department' than a leader, Dr Cooper's tenure was characterised by a long period of stable, sound and transparent management in accordance with advice from the departmental committee and with friendly workplace relations.

Moreover - and most importantly — his term was distinguished at the end of 1997, following his negotiations with the executive dean of the Faculty of Health Sciences, Professor Derek Frewin, by the department's transfer from the Faculty of Arts to the Faculty of Health Sciences. This proved to be a highly successful move. 
Historically, location of psychology within the Faculty of Arts had proved difficult for the department, the needs of which, as a base for behavioural science, had proven time and again not to be well understood in other areas of the university. Although psychology throughout this time always attracted high levels of student enrolments, thereby returning substantial income to university management, and the department managed its annual finances with efficiency and acumen, it had not been able to secure reliable levels of funding under successive university (and later faculty) funding redistribution policies, which required considerable socialisation to support other disciplines.

Despite Chris Cooper's continuing and well-reasoned representation on behalf of the school to those responsible for funding at departmental level, these ongoing difficulties inevitably had implications for the appropriate funding of tutoring support to undergraduate programs, the expanding requirements of computer technology, the maintenance of animal laboratories, the growing test library and the supply of equipment essential to research activities. By 1996, this matter had become a major concern for the department, and John Brebner in particular had made calculations that motivated the departmental committee to seek relocation to an area where the department could retain a larger proportion of what its activities earned. Cooper's leadership, when seeking to implement the changes advocated by the departmental committee, was central to the department's transfer to the Faculty of Health Sciences. In the event, although this move did not entirely solve psychology's funding problems, the relocation achieved a vastly improved working environment. This provided significant new opportunities, which John Taplin was able subsequently to exploit successfully.

\section{Professor John Taplin (2000-03)}

Professor Taplin's arrival in 2000 was a game-changer for the department, and the year was marked by high levels of activity and enthusiasm in all quarters. By year's end there was widespread consensus that 2000 had been a huge success, except for one tragic event. On 13 November, the department received the completely unexpected and devastating news that Inara Proske had died suddenly after contracting a serious illness just a few days earlier. She was only fifty-six years of age and was sadly missed as a much-valued and fondly regarded member of the academic staff, by staff and students alike. Importantly, she was also a close friend of several staff, and her death left a large hole in the social fabric of the department.

Initially recruited as a full-time tutor in 1967, Proske and John Taplin had shared tutoring responsibilities at the time when he was completing his $\mathrm{PhD}$. She had subsequently been promoted to senior tutor and then to lecturer. She was widely acknowledged to be a dedicated teacher who had for thirty-four years mentored successive cohorts of students and inducted them into introductory psychology. 
Proske's death really erased the last link with the system of employing full-time tutoring staff on an annual basis to support undergraduate courses, while at the same time providing tutors with the opportunity to gain teaching experience while completing higher degrees. This system, which had trained several who took up continuing academic careers after completing their PhD degrees, including a few who later became lecturing staff at Adelaide (Ted Nettelbeck, Neil Kirby, Amanda LeCouteur, Jane Mathias, Lynn Ward), was already in decline by the 1990s because of shrinking funding. By the time of Professor Taplin's appointment, it had almost entirely been replaced by short-term contracts with $\mathrm{PhD}$ candidates, co-ordinated by Jill Honnor, who was employed on an annual contract until 2005, to provide limited support within specific semester-length courses or shorter topics. This system had the advantage of providing many more $\mathrm{PhD}$ students with limited teaching experience; but this was at a cost to undergraduate students, who no longer had continuing contact with their tutor on a weekly basis for the duration of a course.

Professor Taplin's four years as head were characterised by extensive revitalisation of diverse activities throughout the department. He proved to be a skilful communicator, who was inclusive in his interactions with staff and students. He also aimed from the outset to raise the profile of the department both within and outside the university. A successful strategy for achieving this, involving all academic and professional staff in planning, involved conducting regular SWOT analyses to inform future developments. By reforming rotating course co-ordination arrangements and restructuring the department's committee structures, he ensured that every member of staff had a voice in the administration of the department's core business, with scope for effective consultation with students and external stakeholders. In collaboration with the Defence Science and Technology Organisation [DSTO] at Edinburgh, he established a senior research fellowship in cognitive psychology, taken up by Douglas Vickers, together with a number of industry-based scholarships for outstanding third-year graduates in psychology, an initiative which opened up future employment opportunities.

Professor Taplin maintained a keen interest in staff welfare and actively advised and encouraged staff to consider professional development opportunities. A direct consequence of this was an increase in external research funding into the department from ARC, NHMRC and other funding bodies; improved publication output by academic staff, especially in higher-impact journals; increased editorial commitments; direct involvement of the department in hosting international conferences; and wider use of the university's Special Studies Program [sabbatical] and overseas conference leave scheme. All teaching staff on casual contracts were required to complete teacher development workshops provided by the university. Past philosophical differences that had tended from time to time to introduce friction about the role of quantitative and qualitative research methods within the teaching program were largely resolved by promoting his opinion that both had a legitimate place. His new liaison program with 
high schools substantially increased undergraduate enrolments during the next few years and assisted the introduction of psychology as Year 11 and Year 12 subjects in secondary schools from 2004.

In this regard, Taplin was well assisted by Carmen Rayner, who had initially been appointed to the professional staff in 1990, to cover the need then for photography and graphic designs, skills required for the production of conference posters and for the graphic presentation of published research by academic staff. However, by 2000 changing technology had rendered such duties increasingly obsolete and Rayner had progressively retrained to meet requirements in the marketing of psychology programs and in student recruitment. She was to continue in this line, and during Ted Nettelbeck's time as head she moved into the role of full-time student liaison officer, a position that she held for twenty-three years of loyal service.

Consistent with the university's increasing commitment to the provision of international places, John Taplin also established a Foundation Studies Program in Psychology for international students commencing at the university's Bradford College from 2004. He also established several new undergraduate programs, including a Bachelor of Psychology for international students and the Bachelor of Psychology (Honours) program, which guaranteed honours placement, outside the otherwise competitive entry requirements based on success in psychology courses at university, for the most academically successful Year 12 graduates. This program had the highest TER/ATAR cut-off for entry of any named degree program in psychology in Australia (around 99.95), from its start-up in 2001 until 2014, when it was discontinued because of a change in the university's requirements for unique content in named degrees. $\mathrm{He}$ attracted additional funding that enabled major upgrade to the Psychology Test Library, expanded psychology holdings in the Barr Smith Library, extended undergraduate and postgraduate computer laboratories, improved postgraduate equipment and strengthened the link between the department and the South Australian branch of the APS, a process which also included the re-establishment of the Psychology Students' Society.

At the postgraduate level, Professor Taplin's term as head was marked by substantial growth in the number of higher degrees by research [HDR]. This was achieved in part by his introduction of a four-year combined PhD/Master of Psychology (Clinical) degree that attracted high-performing honours graduates wishing to pursue both clinical and research interests. He oversaw a revision of the curriculum for the Master of Psychology (Clinical) program, which improved clinical skills training and established a new psychology clinic under the management of clinical psychologist Brian Williams within primary mental health services, in collaboration with the university's Department of General Practice. He also extended future opportunities for additional honours graduates by establishing a new Master of Psychology (Organisational and Human Factors). 
These expansions had the potential to increase student numbers within a context where the student-to-staff ratio was already high; however, by significantly increasing the numbers of appropriately qualified honorary affiliate, adjunct and clinical title holders willing to contribute to teaching, research supervision and field activities, these changes were successfully accommodated. Taplin's term saw the renewal of national accreditation for all undergraduate courses and programs and both Master of Psychology programs as well as substantial improvement in student satisfaction with the quality of teaching, as registered by national surveys completed by graduates with both undergraduate and postgraduate degrees.

The Disability Research Unit [DRU], under the direction of Dr Neil Kirby, was first established within the department in 2001. It was the result of a successful application for ARC SPIRT funding by Kirby, Nettelbeck and Taplin, with the South Australian [SA] Department of Human Services as the industry partner. This collaboration was established through the input of Dr David Caudrey, who had achieved honours at Adelaide in 1969 before completing his $\mathrm{PhD}$ at University College, London, and later returning to Adelaide, where he enjoyed a distinguished career in the field of disability. The original aim of the DRU was to develop a new instrument for evaluating support needs for different types, levels and combinations of disability. This was accomplished by successive funding through the SA Department of Communities and Social Inclusion and the dedicated contributions of researchers appointed to the DRU, principally Dr Julia Harries, Dr Leah Wilson, Roma Guscia and Rakesh Chandrasekharan. Over time, the focus of this unit has broadened to include risk profiles for areas beyond disability, and in 2015, to reflect this change, it was renamed the Wellbeing Research Unit.

During Professor Taplin's four years as head it would be fair to say that, although the staffing profile of the department had been relatively stable for a long time, he produced more change than had been evident during the previous twenty years, thereby significantly reinvigorating the working environment. Moreover, following his retirement as head, in his new role as the university's Pro Vice-Chancellor (International), Professor Taplin was in a strong position to help develop the department's links with schools and institutes of psychology overseas, particularly in the Asia-Pacific region, thereby fulfilling the expectations placed on the department as the university continued to increase the numbers of international students that it attracted.

\section{Professor Ted Nettelbeck (2004-06)}

Ted Nettelbeck succeeded John Taplin as head of department from the beginning of 2004, when Professor Taplin resigned the headship. Nettelbeck exemplified the 'home-grown product', with a career entirely within the University of Adelaide, from his first appointment as a full-time tutor while completing a $\mathrm{PhD}$, to eventual tenured 
academic status. He was well prepared for the role of head, having served for many years as deputy to both Chris Cooper and John Taplin. In 2004, the department was in exceptionally good shape because Professor Taplin had largely achieved the stimulating and collegial work environment that he had set out to shape, with sound management structures operating efficiently, a healthy financial position and a well-developed future strategic plan in place, to the development of which all staff had contributed.

Professor Nettelbeck largely saw his role as building on the excellent example set by his predecessor. His first appointment was to fill the position of departmental administrator, vacated by Iris Liu when she was offered the opportunity of transferring to the office of the Pro Vice Chancellor (International) when John Taplin took up his new position. Liu, who had emigrated from Hong Kong, had first begun in the department's general office in 1989, but had been promoted to departmental secretary for Chris Cooper and then the departmental administrator for John Taplin. Her keen efficiency and warm disposition had been greatly valued by all staff and there was initially some concern about having to replace her. However, as a consequence of her shift to the office of the pro vice-chancellor, Carola Sanders was appointed, and she commenced in 2004 as the new departmental administrator, a role that morphed into school administration manager when the Department of Psychology became a school in 2006, subsequently being promoted to school manager. Sanders was, indeed, a very successful appointment and over the decade that followed she continued to provide the extremely high quality of managerial support that successive heads have found invaluable.

One of the first changes that Ted Nettelbeck instigated was on a purely practical front, and involved installing air-conditioning units in all offices throughout the school. Temperatures in offices on Level 5 of the Hughes building, where most lecturing staff were housed, routinely soared well above $40^{\circ}$ Celsius in the summer, causing desktop computers to fail and making working conditions for staff intolerable. Concerned that there was a serious risk that summer deadlines for the submission of competitive funding applications could be jeopardised, Nettelbeck, with Bob Willson's help, used the departmental budget to purchase small inexpensive reverse-cycle air conditioners that were successfully installed in the windows of all staff offices.

On the academic front, during his three years as head, Nettelbeck made several changes to the academic staff establishment list. Dr Peter Strelan, a social psychologist with expertise in forgiveness and social justice, was appointed following Associate Professor John Brebner's retirement in 2005, to expand the coverage of social psychology. Dr Dan Navarro was appointed in 2006, following Dr Delin's retirement. A graduate and postgraduate of the department, he returned here after a postdoctoral appointment at Ohio State University in the US. His appointment immediately strengthened the school's coverage of cognitive science, mathematical psychology and 
statistics, and his subsequent contribution to the school's research output was increased by his later award of a prestigious ARC Future Fellowship.

However, other significant changes that occurred at this time were the consequence of the unexpected death in October 2004 of Professor Douglas Vickers at the age of only sixty-four. At the time, Professor Vickers was deputy head. He had had a distinguished career in several fields including psychophysics, perception and memory, had been awarded the ScD degree by the University of Cambridge in 1994 for his contributions to science and learning, and had recently been made a fellow of the Academy of Sciences of Australia. Until his death, an important focus of planning in the department during 2004 had been on developing a Centre of Excellence to be led by Vickers in mathematical modelling of decision making, the primary field within which he had established his considerable international reputation for research and scholarship.

Although the department was successful around this time in securing appointments relevant to this initiative — that is, Dr Michael Lee (2001 and 2004), Dr Simon Dennis (2005) and Dr Dan Navarro (2006) - Professor Vickers's death meant that the Centre of Excellence initiative was not further pursued. Dr John Dunn was appointed to the position that had been held by Vickers in 2005; and both Simon Dennis and Michael Lee left in 2006 and 2007, respectively. They were replaced by Dr Carolyn Semmler (2006), a Flinders graduate with expertise in psychology and the law and, during Professor Turnbull's tenure as head of school, Dr Amy Perfors (2008), who had trained in the US with a PhD from Boston, and whose main interests were in language acquisition and higher-order cognition.

In late 2004, a new Centre for Treatment of Anxiety and Depression [CTAD] was opened by Premier Mike Rann, with the help of the famous Australian comic actor, Garry McDonald, at the university's Thebarton campus. Initially set up in collaboration with Mental Health Services at the Queen Elizabeth Hospital, and subsequently with the Central Northern Adelaide Health Service, CTAD has continued to provide placements for students enrolled in the Master of Psychology (Clinical and Health) programs. CTAD replaced an earlier, smaller departmental clinic at Thebarton, which had operated successfully in support of clinical master's students under the direction of Dr Don Pritchard, who had been seconded from State Health for some years as a senior lecturer to help build the department's clinical expertise. In this role, he had enjoyed considerable support from Lisa Kettler, a former Adelaide graduate (MClinPsych, PhD) who continued to make substantial contributions to the school's clinical program until her departure at the beginning of 2013.

However, the major context within which the department operated throughout 2005 was the planned restructuring of the Faculty of Health Sciences instigated by the new executive dean, Professor Justin Beilby. Nettelbeck's primary concern was to 
secure the status of psychology as an independent school with an operating budget that reflected its teaching and research activities. This was substantially achieved by early 2006, at which time Nettelbeck became the first head of school. However, that psychology emerged as a single-discipline school was in part due to the sound negotiating skills of Professor Deb Turnbull, at that time deputy head. The outcome probably also owed something to Turnbull's and Nettelbeck's prior extensive facultyand university-wide administrative experience, including Nettelbeck's long-term responsibility for management of the Faculty of Health Science's higher degrees program, a role that required close working with senior faculty management.

The single most traumatic event during 2005 was what the university euphemistically referred to as 'a water incident' but which has gone down in the annals of the school's history as 'the great flood'. On Friday 11 March, a workman engaged on university maintenance in the area just outside the northeast corner of the Elder Conservatorium accidentally put a pickaxe through the underground main water supply in that area. Within a very short time the flood of water from the ruptured pipe had broken through the deck of the outside plaza and flooded down to Level 2 of the Hughes building, entering through psychology's Cognitive Abilities Laboratory and causing more than $\$ 100000$ damage there to computers, tests, office furniture and other materials and to the structure of the building, which subsequently required major repairs. The water then spread throughout Level 2, where most HDR students were accommodated and where the school's computing laboratories and computer server were located, causing extensive damage at floor level, before flowing on down to flood Level 1, which at the time was mostly teaching rooms and storage for equipment. The replacement of materials and equipment damaged was eventually to exceed an additional $\$ 100000$, although, in the end, there were some benefits from these disastrous circumstances: it was possible to replace outdated electrophysiological equipment with a new neuroscan system and the substantial repair and replacement program undertaken by the university triggered a program of renovation throughout the school which continued for the next several years.

With 1956 as the foundation year for the Department of Psychology at the University of Adelaide, 2006 became the Golden Anniversary, celebrated in considerable style at a dinner dance at the Radisson Playford Hotel with a large crowd of past and present staff and students in attendance. Guests travelling from interstate for the occasion were Syd and Joan Lovibond, Peter and Roslyn Glow and Don and Kathie McNicoll; and Malcolm and Ruth Jeeves sent congratulations from St Andrews.

The year 2006 also saw a significant increase over previous years in the numbers of $\mathrm{PhD}$ completed within a single year (see Table 3.1). Numbers of candidates enrolling annually for the $\mathrm{PhD}$ degree had gradually increased during the past forty years, but from henceforth completions would average about twelve a year. In 2015, the school had eighty-five $\mathrm{PhD}$ enrolments at various stages of their projects, a very high 
number for a continuing academic staff establishment list of twenty-three, given the high numbers of annual honours and master's theses requiring supervision. This level of supervision has been aided by the considerable expansion in title holders, initially begun by John Taplin back in 2000. By 2015, there were seventy-seven clinical title holders, fifty-three visiting research fellows and two emeritus professors (Glow and Nettelbeck).

Table 3.1 Doctor of Philosophy degrees completed in psychology 2000-15.

Source: Author's own work.

\begin{tabular}{|c|c|c|c|}
\hline Year & Name & Title & Supervisor \\
\hline 2000 & $\begin{array}{l}\text { Justine Kate } \\
\text { Dandy }\end{array}$ & $\begin{array}{l}\text { IQ and academic achievement among } \\
\text { Australian students from Chinese and } \\
\text { Vietnamese backgrounds }\end{array}$ & Ted Nettelbeck \\
\hline 2000 & $\begin{array}{l}\text { Kyle Roydon } \\
\text { Dyer }\end{array}$ & $\begin{array}{l}\text { Determinants of opioid effects and } \\
\text { withdrawal among methadone } \\
\text { maintenance patients }\end{array}$ & $\begin{array}{l}\text { Jason White } \\
\text { and Frank } \\
\text { Dalziel }\end{array}$ \\
\hline 2000 & Monique Kardos & $\begin{array}{l}\text { A study in behaviour conservation: } \\
\text { Applying ecological learning theory } \\
\text { to the maintenance of species-typical } \\
\text { behaviour in small carnivores in a zoo } \\
\text { environment }\end{array}$ & $\begin{array}{l}\text { Frank Dalziel } \\
\text { and Tony } \\
\text { Winefield }\end{array}$ \\
\hline 2000 & $\begin{array}{l}\text { Elizabeth Helene } \\
\text { Kummerow }\end{array}$ & $\begin{array}{l}\text { Towards the measurement of } \\
\text { organisational culture }\end{array}$ & Neil Kirby \\
\hline 2000 & John Raftery & $\begin{array}{l}\text { 'Nothing New to Medical Science': } \\
\text { The construction of war neurosis and } \\
\text { the life course outcomes of WWII } \\
\text { veterans }\end{array}$ & $\begin{array}{l}\text { Neville Hicks } \\
\text { and Ian John }\end{array}$ \\
\hline 2000 & Tahereh Ziaian & $\begin{array}{l}\text { The psychological effects of migration } \\
\text { on Persian women immigrants in } \\
\text { Australia }\end{array}$ & $\begin{array}{l}\text { Martha } \\
\text { Augoustinos }\end{array}$ \\
\hline 2001 & $\begin{array}{l}\text { Natalie } \\
\text { Elizabeth } \\
\text { Beaumont- } \\
\text { Smith }\end{array}$ & $\begin{array}{l}\text { Cultural, social and individual aspects } \\
\text { of food cognitions }\end{array}$ & $\begin{array}{l}\text { Tony Worsley } \\
\text { and Martha } \\
\text { Augoustinos }\end{array}$ \\
\hline
\end{tabular}




\begin{tabular}{|c|c|c|c|}
\hline 2001 & $\begin{array}{l}\text { Timothy } \\
\text { Connell }\end{array}$ & $\begin{array}{l}\text { The role of basal ganglia in cognition } \\
\text { and language }\end{array}$ & $\begin{array}{l}\text { Peter Delin and } \\
\text { Jo Wale }\end{array}$ \\
\hline 2001 & $\begin{array}{l}\text { Moira Fay } \\
\text { Jenkins }\end{array}$ & $\begin{array}{l}\text { Workplace bullying: The perceptions } \\
\text { of the target, the alleged perpetrator } \\
\text { and the HR professional }\end{array}$ & Helen Winefield \\
\hline 2001 & $\begin{array}{l}\text { Carla Anita } \\
\text { Litchfield }\end{array}$ & $\begin{array}{l}\text { The facilitation of exploratory } \\
\text { behaviour and other behavioural } \\
\text { changes by the presentation of novel } \\
\text { objects to rats, chimpanzees and } \\
\text { caracals }\end{array}$ & $\begin{array}{l}\text { Frank Dalziel } \\
\text { and Tony } \\
\text { Winefield }\end{array}$ \\
\hline 2001 & Lance Storm & $\begin{array}{l}\text { Investigation of the theory of } \\
\text { psychopaxia: Experimental and } \\
\text { theoretical researches into an } \\
\text { alternative theory explaining normal } \\
\text { and paranormal phenomena }\end{array}$ & $\begin{array}{l}\text { Michael } \\
\text { Thalborne and } \\
\text { Peter Delin }\end{array}$ \\
\hline 2002 & $\begin{array}{l}\text { Marcus Antanas } \\
\text { Butavicius }\end{array}$ & $\begin{array}{l}\text { The recognition of planar rotated and } \\
\text { scaled forms: Normalisation versus } \\
\text { invariant features }\end{array}$ & Doug Vickers \\
\hline 2002 & $\begin{array}{l}\text { Benjamin James } \\
\text { W Grindlay }\end{array}$ & $\begin{array}{l}\text { Missing the point: The effect of } \\
\text { punctuation on reading performance }\end{array}$ & Peter Delin \\
\hline 2002 & $\begin{array}{l}\text { Anne-Louise } \\
\text { Hordacre }\end{array}$ & $\begin{array}{l}\text { Anxiety and depression in } \\
\text { postpartum women }\end{array}$ & Don Pritchard \\
\hline 2002 & $\begin{array}{l}\text { Kathryn Mary } \\
\text { Lampard }\end{array}$ & $\begin{array}{l}\text { The effects of movable novel objects, } \\
\text { novel olfactory stimuli and novel } \\
\text { auditory stimuli on the exploratory, } \\
\text { play and stereotypical behaviour of } \\
\text { captive species: A comparative study }\end{array}$ & $\begin{array}{l}\text { Frank Dalziel } \\
\text { and Vanessa } \\
\text { Mills }\end{array}$ \\
\hline 2002 & $\begin{array}{l}\text { Daniel Joseph } \\
\text { Navarro }\end{array}$ & Representing stimulus similarity & $\begin{array}{l}\text { Michael Lee } \\
\text { and Doug } \\
\text { Vickers }\end{array}$ \\
\hline 2002 & Aspa Sarris & $\begin{array}{l}\text { Australians in Antarctica: A study of } \\
\text { organisational culture }\end{array}$ & $\begin{array}{l}\text { Neil Kirby and } \\
\text { Joan Russell }\end{array}$ \\
\hline 2002 & $\begin{array}{l}\text { Matthew Brian } \\
\text { Welsh }\end{array}$ & $\begin{array}{l}\text { Of mice and men: The structure and } \\
\text { bases of murine cognitive abilities }\end{array}$ & Ted Nettelbeck \\
\hline
\end{tabular}




\begin{tabular}{|c|c|c|c|}
\hline 2003 & James Houran & $\begin{array}{l}\text { Conceptualising transliminality as } \\
\text { functional regulation of interaction } \\
\text { among brain regions }\end{array}$ & $\begin{array}{l}\text { Michael } \\
\text { Thalbourne }\end{array}$ \\
\hline 2003 & Lisa Joy Kettler & $\begin{array}{l}\text { Psychological determinants of } \\
\text { treatment adherence in adults with } \\
\text { cystic fibrosis }\end{array}$ & $\begin{array}{l}\text { Helen Winefield } \\
\text { and Hugh } \\
\text { Greville }\end{array}$ \\
\hline 2003 & Sue Pearson & $\begin{array}{l}\text { Surgical stress: The role of } \\
\text { psychological factors in the } \\
\text { determination of stress responses and } \\
\text { recovery from surgery }\end{array}$ & $\begin{array}{l}\text { Guy Maddern } \\
\text { and John } \\
\text { Brebner }\end{array}$ \\
\hline 2003 & $\begin{array}{l}\text { Leah Ruth } \\
\text { Wilson }\end{array}$ & $\begin{array}{l}\text { Resident and resident-related } \\
\text { committees and meetings in South } \\
\text { Australian aged care hostels }\end{array}$ & Neil Kirby \\
\hline 2004 & $\begin{array}{l}\text { Matthew } \\
\text { Baldock }\end{array}$ & $\begin{array}{l}\text { Self-regulation of the driving } \\
\text { behaviour of older drivers }\end{array}$ & Jane Mathias \\
\hline 2004 & $\begin{array}{l}\text { Janine Jade } \\
\text { Peckham }\end{array}$ & $\begin{array}{l}\text { Organisational factors that can } \\
\text { affect employee acceptance of new } \\
\text { information technology }\end{array}$ & Neil Kirby \\
\hline 2005 & $\begin{array}{l}\text { Andrew John } \\
\text { Bate }\end{array}$ & $\begin{array}{l}\text { The nature and assessment of } \\
\text { attentional function following severe } \\
\text { traumatic brain injury }\end{array}$ & $\begin{array}{l}\text { Jane Mathias } \\
\text { and John } \\
\text { Crawford }\end{array}$ \\
\hline 2005 & Gemma Munro & $\begin{array}{l}\text { I sing, therefore I am: A discursive } \\
\text { investigation of work, performance } \\
\text { and identity }\end{array}$ & $\begin{array}{l}\text { Amanda } \\
\text { LeCouteur }\end{array}$ \\
\hline 2005 & $\begin{array}{l}\text { Della Marie } \\
\text { Steen }\end{array}$ & $\begin{array}{l}\text { Chronic pain and depression: A } \\
\text { cognitive-behavioural mediation } \\
\text { model approach }\end{array}$ & $\begin{array}{l}\text { Don Pritchard } \\
\text { and Eric Rump }\end{array}$ \\
\hline 2006 & $\begin{array}{l}\text { Veneta Anne } \\
\text { Bastian }\end{array}$ & $\begin{array}{l}\text { Are the claims for emotional } \\
\text { intelligence justified? Emotional } \\
\text { intelligence predicts life skills, but not } \\
\text { as well as personality and cognitive } \\
\text { abilities }\end{array}$ & $\begin{array}{l}\text { Ted Nettelbeck } \\
\text { and Nick Burns }\end{array}$ \\
\hline
\end{tabular}




\begin{tabular}{|c|c|c|c|}
\hline 2006 & Robert Burns & $\begin{array}{l}\text { Scientific knowledge-production } \\
\text { and progress: Neuropsychological } \\
\text { knowledge and the contemporary } \\
\text { specialty of clinical neuropsychology }\end{array}$ & $\begin{array}{l}\text { Peter Delin and } \\
\text { Ian John }\end{array}$ \\
\hline 2006 & Shona Crabb & $\begin{array}{l}\text { A discursive analysis of accounts } \\
\text { of breast cancer screening, risk and } \\
\text { prevention }\end{array}$ & $\begin{array}{l}\text { Amanda } \\
\text { LeCouteur and } \\
\text { Deb Turnbull }\end{array}$ \\
\hline 2006 & Linley Denson & $\begin{array}{l}\text { Values and long-term care decision- } \\
\text { making for frail elderly people }\end{array}$ & $\begin{array}{l}\text { Helen Winefield } \\
\text { and Ted } \\
\text { Nettelbeck }\end{array}$ \\
\hline 2006 & Jaklin A Eliott & $\begin{array}{l}\text { The do-not-resuscitate decision: } \\
\text { A discursive analysis of cancer } \\
\text { patients' talk }\end{array}$ & Ian Olver \\
\hline 2006 & Danielle Every & $\begin{array}{l}\text { The politics of representation: } \\
\text { A discursive analysis of refugee } \\
\text { advocacy in the Australian parliament }\end{array}$ & $\begin{array}{l}\text { Martha } \\
\text { Augoustinos } \\
\text { and Amanda } \\
\text { LeCouteur }\end{array}$ \\
\hline 2006 & $\begin{array}{l}\text { Katherine } \\
\text { Hodgetts }\end{array}$ & $\begin{array}{l}\text { Gendering achievement: A discursive } \\
\text { investigation of the House of } \\
\text { Representatives inquiry into the } \\
\text { education of boys }\end{array}$ & $\begin{array}{l}\text { Martha } \\
\text { Augoustinos } \\
\text { and Amanda } \\
\text { LeCouteur }\end{array}$ \\
\hline 2006 & $\begin{array}{l}\text { Kieran } \\
\text { O’Doherty }\end{array}$ & $\begin{array}{l}\text { Risk communication in familial } \\
\text { cancer: The discursive management of } \\
\text { uncertainty in genetic counselling }\end{array}$ & $\begin{array}{l}\text { Martha } \\
\text { Augoustinos } \\
\text { and Amanda } \\
\text { LeCouteur }\end{array}$ \\
\hline 2006 & $\begin{array}{l}\text { Alexandra } \\
\text { Osborn }\end{array}$ & $\begin{array}{l}\text { A national profile and review of } \\
\text { services and interventions for children } \\
\text { and young people with high support } \\
\text { needs in Australian out-of-home care }\end{array}$ & $\begin{array}{l}\text { Paul Delfabbro } \\
\text { and Helen } \\
\text { Winefield }\end{array}$ \\
\hline 2006 & $\begin{array}{l}\text { Dorota } \\
\text { Pomagalska }\end{array}$ & $\begin{array}{l}\text { The reification of self-esteem: } \\
\text { Grammatical investigations into } \\
\text { scientific and popular texts }\end{array}$ & $\begin{array}{l}\text { Martha } \\
\text { Augoustinos }\end{array}$ \\
\hline
\end{tabular}




\begin{tabular}{|c|c|c|c|}
\hline 2006 & Adrian Preiss & $\begin{array}{l}\text { A theoretical and computational } \\
\text { investigation into aspects of human } \\
\text { visual perception: Proximity and } \\
\text { transformations in pattern detection } \\
\text { and discrimination }\end{array}$ & $\begin{array}{l}\text { Doug Vickers } \\
\text { and Nick Burns }\end{array}$ \\
\hline 2006 & Damien Riggs & $\begin{array}{l}\text { Benevolence, belonging and the } \\
\text { repression of white violence }\end{array}$ & $\begin{array}{l}\text { Martha } \\
\text { Augoustinos }\end{array}$ \\
\hline 2006 & Janette Warwick & $\begin{array}{l}\text { Emotional intelligence: A } \\
\text { psychometric study }\end{array}$ & $\begin{array}{l}\text { Ted Nettelbeck } \\
\text { and Lynn Ward }\end{array}$ \\
\hline 2007 & $\begin{array}{l}\text { Yvonne } \\
\text { Bentham }\end{array}$ & $\begin{array}{l}\text { The influence of parenting goals on } \\
\text { adolescent psychosocial adjustment }\end{array}$ & $\begin{array}{l}\text { John Taplin } \\
\text { and Paul } \\
\text { Delfabbro }\end{array}$ \\
\hline 2007 & Matthew Davies & $\begin{array}{l}\text { The development and validation of } \\
\text { a cognitive-behavioural measure of } \\
\text { psychological mindedness }\end{array}$ & $\begin{array}{l}\text { John Taplin } \\
\text { and Helen } \\
\text { Winefield }\end{array}$ \\
\hline 2007 & Matthew Dry & $\begin{array}{l}\text { Comparing models of symmetry } \\
\text { perception }\end{array}$ & $\begin{array}{l}\text { Doug Vickers, } \\
\text { Michael Lee, } \\
\text { Nick Burns and } \\
\text { Simon Dennis }\end{array}$ \\
\hline 2007 & Taryn Elliott & $\begin{array}{l}\text { An exploration of unit commander } \\
\text { decision-making in the Australian } \\
\text { army }\end{array}$ & $\begin{array}{l}\text { Ted Nettelbeck } \\
\text { and Vanessa } \\
\text { Mills }\end{array}$ \\
\hline 2007 & Tess Gregory & $\begin{array}{l}\text { Inspection time as a biological marker } \\
\text { for functional age }\end{array}$ & $\begin{array}{l}\text { Ted Nettelbeck } \\
\text { and Carlene } \\
\text { Wilson }\end{array}$ \\
\hline 2007 & Sara Howard & $\begin{array}{l}\text { Predicting independent functioning } \\
\text { in an elderly population: The } \\
\text { evaluation of working memory } \\
\text { capacity as a biomarker of ageing }\end{array}$ & $\begin{array}{l}\text { Ted Nettelbeck } \\
\text { and Carlene } \\
\text { Wilson }\end{array}$ \\
\hline 2007 & Mark Mackay & $\begin{array}{l}\text { Compartmental flow modelling of } \\
\text { acute care hospital bed occupancy for } \\
\text { strategic decision-making }\end{array}$ & $\begin{array}{l}\text { Simon Dennis } \\
\text { and Michael } \\
\text { Lee }\end{array}$ \\
\hline 2007 & Neha Mahajan & $\begin{array}{l}\text { Biopsychosocial associates of } \\
\text { infertility-related distress and } \\
\text { treatment outcomes }\end{array}$ & $\begin{array}{l}\text { Deb Turnbull } \\
\text { and John } \\
\text { Taplin }\end{array}$ \\
\hline
\end{tabular}




\begin{tabular}{|c|c|c|c|}
\hline 2007 & Stacey Panozzo & $\begin{array}{l}\text { Lessons to be learnt: Evaluating } \\
\text { aspects of patient safety culture and } \\
\text { quality improvement within an } \\
\text { intensive care unit }\end{array}$ & $\begin{array}{l}\text { Neil Kirby and } \\
\text { Helen Winefield }\end{array}$ \\
\hline 2007 & Nancy White & $\begin{array}{l}\text { Parental responsibility for the illicit } \\
\text { acts of their children }\end{array}$ & $\begin{array}{l}\text { John Taplin } \\
\text { and Martha } \\
\text { Augoustinos }\end{array}$ \\
\hline 2007 & Lisa Wundersitz & $\begin{array}{l}\text { Characteristics identifying young } \\
\text { drivers at a higher risk of crashing }\end{array}$ & Nick Burns \\
\hline 2008 & Nadia Corsini & $\begin{array}{l}\text { Exploring aspects of parental control } \\
\text { over feeding: Influences on children's } \\
\text { eating behaviour and weight }\end{array}$ & $\begin{array}{l}\text { Carlene Wilson, } \\
\text { Lisa Kettler } \\
\text { and Vanessa } \\
\text { Danthiir }\end{array}$ \\
\hline 2008 & Kirsten Dunn & $\begin{array}{l}\text { Fast-food consumption: Application } \\
\text { and extension of the theory of } \\
\text { planned behaviour to incorporate } \\
\text { affective responses and implicit } \\
\text { associations }\end{array}$ & $\begin{array}{l}\text { Phil Mohr, } \\
\text { Carlene Wilson } \\
\text { and Gary } \\
\text { Wittert }\end{array}$ \\
\hline 2008 & Edwina Farrall & $\begin{array}{l}\text { Optimism in child development: } \\
\text { Conceptual issues and } \\
\text { methodological approaches }\end{array}$ & $\begin{array}{l}\text { John Taplin } \\
\text { and Lisa Kettler }\end{array}$ \\
\hline 2008 & Monica Goretzki & $\begin{array}{l}\text { The differentiation of psychosis and } \\
\text { spiritual emergency }\end{array}$ & $\begin{array}{l}\text { Michael } \\
\text { Thalbourne and } \\
\text { Lance Storm }\end{array}$ \\
\hline 2008 & Rebecca Grivas & $\begin{array}{l}\text { An examination of emotion-based } \\
\text { strategies in 'altruistic' mobilisation: } \\
\text { A case study of the animal rights } \\
\text { movement }\end{array}$ & $\begin{array}{l}\text { Martha } \\
\text { Augoustinos } \\
\text { and Peter } \\
\text { White }\end{array}$ \\
\hline 2008 & Julia Harries & $\begin{array}{l}\text { Support needs assessment for } \\
\text { individuals with intellectual } \\
\text { disabilities: An investigation of the } \\
\text { nature of the support needs construct } \\
\text { and disability factors that impact on } \\
\text { support needs }\end{array}$ & $\begin{array}{l}\text { Neil Kirby, Ted } \\
\text { Nettelbeck and } \\
\text { John Taplin }\end{array}$ \\
\hline
\end{tabular}




\begin{tabular}{|c|c|c|c|}
\hline 2008 & Vikki Knott & $\begin{array}{l}\text { A focus on disability and psychosocial } \\
\text { aspect in an illness with an organic } \\
\text { cause (cancer) and an illness with a } \\
\text { non-organic cause (IBS) }\end{array}$ & $\begin{array}{l}\text { Deb Turnbull } \\
\text { and Tony } \\
\text { Winefield }\end{array}$ \\
\hline 2008 & Yung-Li Ku & $\begin{array}{l}\text { A test of competing models to predict } \\
\text { suicidality in patients and students in } \\
\text { Taiwan }\end{array}$ & $\begin{array}{l}\text { Helen Winefield } \\
\text { and Nick Burns }\end{array}$ \\
\hline 2008 & Donel Martin & $\begin{array}{l}\text { Gonadal steroids and cognitive } \\
\text { functioning in middle- to older-aged } \\
\text { males }\end{array}$ & $\begin{array}{l}\text { Gary Wittert } \\
\text { and Nick Burns }\end{array}$ \\
\hline 2008 & $\begin{array}{l}\text { Jason } \\
\text { McPherson }\end{array}$ & $\begin{array}{l}\text { Development and assessment of } \\
\text { computer-game-like tests of human } \\
\text { cognitive abilities }\end{array}$ & $\begin{array}{l}\text { Nick Burns and } \\
\text { Michael Lee }\end{array}$ \\
\hline 2008 & $\begin{array}{l}\text { Shruti } \\
\text { Mujumdar }\end{array}$ & $\begin{array}{l}\text { Work stress in Australian } \\
\text { professionals: The role of culture, } \\
\text { gender and work-family conflict }\end{array}$ & $\begin{array}{l}\text { Helen Winefield } \\
\text { and Neil Kirby }\end{array}$ \\
\hline 2008 & Peter Murphy & $\begin{array}{l}\text { Readiness, resilience, and } \\
\text { readjustment: A psychological } \\
\text { investigation on human factors } \\
\text { across the deployment cycle of } \\
\text { contemporary peace support } \\
\text { operations }\end{array}$ & $\begin{array}{l}\text { Ted Nettelbeck } \\
\text { and Gerry } \\
\text { Fogarty }\end{array}$ \\
\hline 2008 & Birgit Pfitzer & $\begin{array}{l}\text { A step towards a broader } \\
\text { understanding of complex } \\
\text { traumatisation in victims of crime: } \\
\text { Psychological and physical health } \\
\text { impacts and implications for } \\
\text { psychological interventions and } \\
\text { treatment evaluation }\end{array}$ & $\begin{array}{l}\text { Paul Delfabbro, } \\
\text { Deb Turnbull } \\
\text { and John } \\
\text { Raftery }\end{array}$ \\
\hline 2008 & Stacey Thomson & $\begin{array}{l}\text { Predicting support needs for people } \\
\text { with psychiatric and intellectual } \\
\text { disabilities }\end{array}$ & $\begin{array}{l}\text { Neil Kirby and } \\
\text { Ted Nettelbeck }\end{array}$ \\
\hline 2009 & $\begin{array}{l}\text { Josephine Anne } \\
\text { Carbone }\end{array}$ & $\begin{array}{l}\text { The mental health and well-being of } \\
\text { children and adolescents in home- } \\
\text { based foster care in South Australia }\end{array}$ & $\begin{array}{l}\text { Paul Delfabbro } \\
\text { and Michael } \\
\text { Sawyer }\end{array}$ \\
\hline
\end{tabular}




\begin{tabular}{|c|c|c|c|}
\hline 2009 & $\begin{array}{l}\text { Amanda } \\
\text { Hutchinson }\end{array}$ & $\begin{array}{l}\text { Corpus callosum morphology } \\
\text { and function in attention deficit } \\
\text { hyperactivity disorder and the } \\
\text { relationship between the corpus } \\
\text { callosum and cognitive functioning in } \\
\text { healthy adults }\end{array}$ & $\begin{array}{l}\text { Jane Mathias } \\
\text { and Marie } \\
\text { Banich }\end{array}$ \\
\hline 2009 & Marek Jantos & $\begin{array}{l}\text { A psychophysiological perspective on } \\
\text { vulvodynia }\end{array}$ & Nick Burns \\
\hline 2009 & Daniel King & $\begin{array}{l}\text { The conceptualisation, status and } \\
\text { measurement of technology-based } \\
\text { gaming behaviour and its correlates }\end{array}$ & $\begin{array}{l}\text { Paul Delfabbro } \\
\text { and Mark } \\
\text { Griffiths }\end{array}$ \\
\hline 2009 & Angela Kinnell & $\begin{array}{l}\text { Item noise versus context noise: Using } \\
\text { the list length effect to investigate the } \\
\text { source of interference in recognition } \\
\text { memory }\end{array}$ & $\begin{array}{l}\text { Simon Dennis } \\
\text { and John Dunn }\end{array}$ \\
\hline 2009 & $\begin{array}{l}\text { Jessica } \\
\text { McCormick }\end{array}$ & $\begin{array}{l}\text { Individual vulnerability and } \\
\text { dissociative-like experiences in regular } \\
\text { and problem gamblers }\end{array}$ & $\begin{array}{l}\text { Paul Delfabbro } \\
\text { and Linley } \\
\text { Denson }\end{array}$ \\
\hline 2009 & $\begin{array}{l}\text { Anthony } \\
\text { Venning }\end{array}$ & $\begin{array}{l}\text { Building mental health in young } \\
\text { Australians: A positive psychological } \\
\text { approach }\end{array}$ & $\begin{array}{l}\text { Lisa Kettler, } \\
\text { Jaklin Eliott } \\
\text { and Anne } \\
\text { Wilson }\end{array}$ \\
\hline 2010 & $\begin{array}{l}\text { Jordan Rachel } \\
\text { Simeon Bell }\end{array}$ & $\begin{array}{l}\text { Educational resilience in primary } \\
\text { school children in South Australia: } \\
\text { An investigation }\end{array}$ & $\begin{array}{l}\text { Lisa Kettler, } \\
\text { and Ted } \\
\text { Nettelbeck }\end{array}$ \\
\hline 2010 & Emily Brindal & $\begin{array}{l}\text { Exploring fast food consumption } \\
\text { behaviours and social influence }\end{array}$ & $\begin{array}{l}\text { Carlene Wilson } \\
\text { and Phil Mohr }\end{array}$ \\
\hline 2010 & Joanne Collins & $\begin{array}{l}\text { Seeking help for mental health issues } \\
\text { in rural South Australia: A mixed } \\
\text { methods approach }\end{array}$ & $\begin{array}{l}\text { Helen } \\
\text { Winefield, } \\
\text { Lynn Ward and } \\
\text { Deb Turnbull }\end{array}$ \\
\hline 2010 & Clemence Due & $\begin{array}{l}\text { A discursive analysis of media } \\
\text { representations of belonging in } \\
\text { Australia }\end{array}$ & $\begin{array}{l}\text { Damien Riggs } \\
\text { and Martha } \\
\text { Augoustinos }\end{array}$ \\
\hline
\end{tabular}




\begin{tabular}{|c|c|c|c|}
\hline 2010 & Kathryn Fogarty & $\begin{array}{l}\text { 'Just say it in your own words': } \\
\text { The social interactional nature of } \\
\text { investigative interviews into child } \\
\text { sexual abuse }\end{array}$ & $\begin{array}{l}\text { Martha } \\
\text { Augoustinos } \\
\text { and Lisa Kettler }\end{array}$ \\
\hline 2010 & $\begin{array}{l}\text { Victoria } \\
\text { Gilliland }\end{array}$ & $\begin{array}{l}\text { Decision making in civil disputes: } \\
\text { The effect of role and frame }\end{array}$ & $\begin{array}{l}\text { John Dunn, } \\
\text { Carolyn } \\
\text { Semmler and } \\
\text { Dan Navarro }\end{array}$ \\
\hline 2010 & $\begin{array}{l}\text { Yasmin } \\
\text { Harman-Smith }\end{array}$ & $\begin{array}{l}\text { A comparison of typically developing } \\
\text { and atypically developing ToM }\end{array}$ & $\begin{array}{l}\text { Ted Nettelbeck } \\
\text { and Lisa Kettler }\end{array}$ \\
\hline 2010 & $\begin{array}{l}\text { Nazariah Sharie } \\
\text { Janon }\end{array}$ & $\begin{array}{l}\text { Effects of the amount of time in child } \\
\text { care on children's cognitive and social } \\
\text { development }\end{array}$ & $\begin{array}{l}\text { Paul Delfabbro } \\
\text { and John } \\
\text { Taplin }\end{array}$ \\
\hline 2010 & $\begin{array}{l}\text { Patricia Mary } \\
\text { McCann } \\
\text { Mortimer }\end{array}$ & $\begin{array}{l}\text { Successful ageing: By whose } \\
\text { definition? }\end{array}$ & $\begin{array}{l}\text { Lynn Ward and } \\
\text { Helen Winefield }\end{array}$ \\
\hline 2010 & Sara McLean & $\begin{array}{l}\text { The challenging behaviour of children } \\
\text { in the South Australian out-of-home } \\
\text { care sector: Stakeholders' experiences } \\
\text { with collaborative practice and their } \\
\text { frameworks for managing behaviour }\end{array}$ & $\begin{array}{l}\text { Lisa Kettler, } \\
\text { Paul Delfabbro } \\
\text { and Damien } \\
\text { Riggs }\end{array}$ \\
\hline 2010 & $\begin{array}{l}\text { Skye Nadine } \\
\text { McLennan }\end{array}$ & $\begin{array}{l}\text { Measurement, causes and impacts of } \\
\text { vascular cognitive impairment and } \\
\text { vascular depression }\end{array}$ & $\begin{array}{l}\text { Jane Mathias } \\
\text { and Simon } \\
\text { Stewart }\end{array}$ \\
\hline 2010 & $\begin{array}{l}\text { Sandra } \\
\text { Pisaniello }\end{array}$ & $\begin{array}{l}\text { Emotion labour, emotion work and } \\
\text { occupational strain in nurses }\end{array}$ & $\begin{array}{l}\text { Helen Winefield } \\
\text { and Paul } \\
\text { Delfabbro }\end{array}$ \\
\hline 2010 & $\begin{array}{l}\text { Alicia Marie } \\
\text { Piteo }\end{array}$ & $\begin{array}{l}\text { Sleep and snoring in infancy: } \\
\text { Prevalence and effects on cognitive } \\
\text { development, maternal mental health } \\
\text { and family functioning }\end{array}$ & $\begin{array}{l}\text { Rachel Roberts, } \\
\text { Declan } \\
\text { Kennedy and } \\
\text { Ted Nettelbeck }\end{array}$ \\
\hline 2010 & Fiona Rillotta & $\begin{array}{l}\text { Family quality of life of Australian } \\
\text { families with a member with an } \\
\text { intellectual/developmental disability: } \\
\text { Measurement issues }\end{array}$ & $\begin{array}{l}\text { Neil Kirby and } \\
\text { Ted Nettelbeck }\end{array}$ \\
\hline
\end{tabular}




\begin{tabular}{|c|c|c|c|}
\hline 2010 & Katie Simmons & $\begin{array}{l}\text { Resisting behavioural change: } \\
\text { Proposal-resistance sequences in } \\
\text { cognitive behavioural therapy sessions } \\
\text { for clients with depression }\end{array}$ & $\begin{array}{l}\text { Amanda } \\
\text { LeCouteur and } \\
\text { Shona Crabb }\end{array}$ \\
\hline 2010 & Benjamin Stone & $\begin{array}{l}\text { The development and assessment of } \\
\text { the semantic fields model of visual } \\
\text { salience }\end{array}$ & $\begin{array}{l}\text { Dan Navarro, } \\
\text { John Dunn and } \\
\text { Simon Dennis }\end{array}$ \\
\hline 2010 & Michael Webb & $\begin{array}{l}\text { New methodologies for modelling } \\
\text { individual differences in cognition }\end{array}$ & Simon Dennis \\
\hline 2010 & Nicole Williams & $\begin{array}{l}\text { Psychological help-seeking: } \\
\text { Understanding men's behaviour }\end{array}$ & $\begin{array}{l}\text { Aspa Sarris and } \\
\text { Neil Kirby }\end{array}$ \\
\hline 2010 & $\begin{array}{l}\text { Ann-Marie } \\
\text { Wordley }\end{array}$ & $\begin{array}{l}\text { Old man's best friend: Animal- } \\
\text { assisted intervention for older people } \\
\text { with dementia }\end{array}$ & $\begin{array}{l}\text { Lisa Kettler and } \\
\text { Helen Winefield }\end{array}$ \\
\hline 2011 & $\begin{array}{l}\text { Peter } \\
\text { Chamberlain }\end{array}$ & $\begin{array}{l}\text { Self murder: Suicide and the } \\
\text { intolerable state of a fragmented self }\end{array}$ & $\begin{array}{l}\text { Paul Delfabbro } \\
\text { and Bob } \\
\text { Goldney }\end{array}$ \\
\hline 2011 & Suzie Cosh & $\begin{array}{l}\text { Elite athletes' experiences of } \\
\text { psychological distress and } \\
\text { psychopathology: A discursive } \\
\text { analysis of athlete identity in contexts } \\
\text { in which athletes are vulnerable to } \\
\text { experiencing psychopathology }\end{array}$ & $\begin{array}{l}\text { Amanda } \\
\text { LeCouteur, Lisa } \\
\text { Kettler and } \\
\text { Shona Crabb }\end{array}$ \\
\hline 2011 & Kayla de la Haye & $\begin{array}{l}\text { The role of friends in adolescent } \\
\text { overweight and weight-related } \\
\text { behaviours: A social network } \\
\text { perspective }\end{array}$ & $\begin{array}{l}\text { Carlene Wilson, } \\
\text { Philip Mohr } \\
\text { and Garry } \\
\text { Robins }\end{array}$ \\
\hline 2011 & Rachel Earl & $\begin{array}{l}\text { An investigation of the effects of lead } \\
\text { on children's cognitive abilities }\end{array}$ & $\begin{array}{l}\text { Nick Burns, } \\
\text { Peter Baghurst } \\
\text { and Ted } \\
\text { Nettelbeck }\end{array}$ \\
\hline 2011 & $\begin{array}{l}\text { Scott Hanson- } \\
\text { Easey }\end{array}$ & $\begin{array}{l}\text { Out of Africa: Sudanese refugees } \\
\text { and the construction of difference in } \\
\text { political and lay talk }\end{array}$ & $\begin{array}{l}\text { Martha } \\
\text { Augoustinos } \\
\text { and Gail } \\
\text { Maloney }\end{array}$ \\
\hline
\end{tabular}




\begin{tabular}{|c|c|c|c|}
\hline 2011 & Stuart Ekberg & $\begin{array}{l}\text { Making arrangements: Remote } \\
\text { proposal sequences and attendant } \\
\text { structural phenomena in social } \\
\text { interaction }\end{array}$ & $\begin{array}{l}\text { Amanda } \\
\text { LeCouteur and } \\
\text { Shona Crabb }\end{array}$ \\
\hline 2011 & Brooke Ferguson & $\begin{array}{l}\text { Children of parents with mental } \\
\text { illness: Parental disclosure, children's } \\
\text { illness beliefs and the development } \\
\text { of a shared understanding of mental } \\
\text { illness in the family }\end{array}$ & $\begin{array}{l}\text { Lisa Kettler } \\
\text { Helen Winefield }\end{array}$ \\
\hline 2011 & Jeremy Goldring & $\begin{array}{l}\text { The development of an implicit } \\
\text { association test for measuring } \\
\text { forgiveness }\end{array}$ & $\begin{array}{l}\text { Peter Strelan } \\
\text { Carolyn } \\
\text { Semmler }\end{array}$ \\
\hline 2011 & Moira Jenkins & $\begin{array}{l}\text { Workplace bullying: The perceptions } \\
\text { of the target, the alleged perpetrator } \\
\text { and the HR professional }\end{array}$ & $\begin{array}{l}\text { Helen Winefield } \\
\text { and Aspa Sarris }\end{array}$ \\
\hline 2011 & $\begin{array}{l}\text { Jodie Merle } \\
\text { Oliver-Baxter }\end{array}$ & $\begin{array}{l}\text { The psychoneuroimmunology of } \\
\text { women experiencing stressful life } \\
\text { events: Testing the oxidative model }\end{array}$ & $\begin{array}{l}\text { Jane Blake } \\
\text { Mortimer, } \\
\text { Deb Turnbull } \\
\text { and Ian } \\
\text { Olver Hayley } \\
\text { Whitford }\end{array}$ \\
\hline 2011 & $\begin{array}{l}\text { Fernando } \\
\text { Marmolejo } \\
\text { Ramos }\end{array}$ & $\begin{array}{l}\text { A graded-embodied theory account } \\
\text { for the processing of emotional } \\
\text { stimuli: The case of sentences, images, } \\
\text { and faces }\end{array}$ & $\begin{array}{l}\text { John Dunn } \\
\text { Anna Ma- } \\
\text { Wyatt }\end{array}$ \\
\hline 2011 & Luke Schneider & $\begin{array}{l}\text { The influence of cerebral lateralisation } \\
\text { on the behaviour of the domestic dog } \\
\text { (canis familiaris) }\end{array}$ & $\begin{array}{l}\text { Paul Delfabbro, } \\
\text { Nicholas Burns }\end{array}$ \\
\hline 2011 & $\begin{array}{l}\text { Amanda May } \\
\text { Taylor }\end{array}$ & $\begin{array}{l}\text { Parenting style and child weight } \\
\text { related outcomes: Measurement, } \\
\text { processes of influence, and the } \\
\text { psychological context }\end{array}$ & $\begin{array}{l}\text { Carlene Wilson, } \\
\text { Phil Mohr and } \\
\text { Amy Slater }\end{array}$ \\
\hline 2011 & Phillip Tully & $\begin{array}{l}\text { Depression, anxiety and morbidity } \\
\text { outcomes after cardiac surgery }\end{array}$ & $\begin{array}{l}\text { Deb Turnbull, } \\
\text { Helen Winefield } \\
\text { and Robert } \\
\text { Baker }\end{array}$ \\
\hline
\end{tabular}




\begin{tabular}{|c|c|c|c|}
\hline 2011 & $\begin{array}{l}\text { Patricia } \\
\text { Wheaton }\end{array}$ & $\begin{array}{l}\text { The impact of pharmacological } \\
\text { treatments on outcome after adult } \\
\text { traumatic brain injury: What does the } \\
\text { research show? }\end{array}$ & $\begin{array}{l}\text { Jane Mathias } \\
\text { and Robert } \\
\text { Vink }\end{array}$ \\
\hline 2011 & Ian Zajac & $\begin{array}{l}\text { Auditory measures of intelligence and } \\
\text { intelligence-related functions: Where } \\
\text { have we come from and where to } \\
\text { from here? }\end{array}$ & $\begin{array}{l}\text { Nicholas Burns, } \\
\text { Ted Nettelbeck } \\
\text { and Vanessa } \\
\text { Danthiir }\end{array}$ \\
\hline 2012 & Ryan Balzan & $\begin{array}{l}\text { The role of cognitive biases in the } \\
\text { development, maintenance and } \\
\text { treatment of delusional belief across } \\
\text { the psychosis continuum }\end{array}$ & $\begin{array}{l}\text { Paul Delfabbro } \\
\text { and Cherrie } \\
\text { Galletly }\end{array}$ \\
\hline 2012 & Dragana Calic & $\begin{array}{l}\text { From the laboratory to the real } \\
\text { world: Evaluating the impact of } \\
\text { impostors, expertise and individual } \\
\text { differences on human face matching } \\
\text { performance }\end{array}$ & $\begin{array}{l}\text { John Dunn, } \\
\text { Veneta } \\
\text { MacLeod, } \\
\text { Anna Ma- } \\
\text { Wyatt and Brett } \\
\text { McLindin }\end{array}$ \\
\hline 2012 & Diana Dorstyn & $\begin{array}{l}\text { Effectiveness of cognitive behaviour } \\
\text { therapy and telecounselling for the } \\
\text { treatment of psychological problems } \\
\text { following spinal cord injury }\end{array}$ & $\begin{array}{l}\text { Jane Mathias } \\
\text { and Linley } \\
\text { Denson }\end{array}$ \\
\hline 2012 & Amy Duncan & $\begin{array}{l}\text { Adherence to rescreening for } \\
\text { colorectal cancer with faecal occult } \\
\text { blood testing }\end{array}$ & $\begin{array}{l}\text { Deb Turnbull } \\
\text { and Carlene } \\
\text { Wilson }\end{array}$ \\
\hline 2012 & $\begin{array}{l}\text { Rebecca } \\
\text { Rosamaria Feo }\end{array}$ & $\begin{array}{l}\text { Asymmetry in interaction on a men's } \\
\text { relationship counselling helpline: } \\
\text { Managing the competing relevancies } \\
\text { of troubles-telling and service } \\
\text { provision }\end{array}$ & $\begin{array}{l}\text { Amanda } \\
\text { LeCouteur and } \\
\text { Shona Crabb }\end{array}$ \\
\hline 2012 & Luke Maurits & $\begin{array}{l}\text { Representation, information theory } \\
\text { and basic word order }\end{array}$ & $\begin{array}{l}\text { Dan Navarro } \\
\text { and Amy } \\
\text { Perfors }\end{array}$ \\
\hline 2012 & $\begin{array}{l}\text { Louise Elizabeth } \\
\text { Joan Mooney }\end{array}$ & $\begin{array}{l}\text { Predicting pro-relational and } \\
\text { pro-social responses to received } \\
\text { forgiveness: The role of state gratitude }\end{array}$ & $\begin{array}{l}\text { Peter Strelan } \\
\text { and Ian McKee }\end{array}$ \\
\hline
\end{tabular}




\begin{tabular}{|c|c|c|c|}
\hline 2012 & Kate Papandrea & $\begin{array}{l}\text { The burden of internalising problems } \\
\text { in South Australian adolescents: A } \\
\text { triple pronged approach to improving } \\
\text { the evidence base for service delivery }\end{array}$ & $\begin{array}{l}\text { Helen Winefield } \\
\text { and Andrew } \\
\text { Livingstone }\end{array}$ \\
\hline 2012 & Rachel Stephens & $\begin{array}{l}\text { The selection and integration of } \\
\text { information to guide inductive } \\
\text { reasoning }\end{array}$ & $\begin{array}{l}\text { Dan Navarro, } \\
\text { Amy Perfors } \\
\text { and John Dunn }\end{array}$ \\
\hline 2013 & Lucinda Clifford & $\begin{array}{l}\text { A qualitative study of medication } \\
\text { adherence amongst people with } \\
\text { schizophrenia }\end{array}$ & $\begin{array}{l}\text { Deb Turnbull, } \\
\text { Cherrie Galletly } \\
\text { and Shona } \\
\text { Crabb }\end{array}$ \\
\hline 2013 & Anastasia Ejova & $\begin{array}{l}\text { The illusion of control: Influencing } \\
\text { factors and underlying psychological } \\
\text { processes }\end{array}$ & $\begin{array}{l}\text { Paul Delfabbro } \\
\text { and Dan } \\
\text { Navarro }\end{array}$ \\
\hline 2013 & $\begin{array}{l}\text { Kristy Diane } \\
\text { Giles }\end{array}$ & $\begin{array}{l}\text { The effect of chemotherapy on } \\
\text { cognition in patients with and } \\
\text { survivors of colorectal cancer }\end{array}$ & $\begin{array}{l}\text { Carlene Wilson, } \\
\text { Amanda } \\
\text { Hutchinson } \\
\text { and Ted } \\
\text { Nettelbeck }\end{array}$ \\
\hline 2013 & $\begin{array}{l}\text { Kate McDonald } \\
\text { Gunn }\end{array}$ & $\begin{array}{l}\text { The psychosocial needs of rural } \\
\text { cancer patients }\end{array}$ & $\begin{array}{l}\text { Deb Turnbull, } \\
\text { Ian Olver, } \\
\text { Jean McWha } \\
\text { and Matthew } \\
\text { Davies }\end{array}$ \\
\hline 2013 & $\begin{array}{l}\text { Rebecca Louise } \\
\text { Heyer }\end{array}$ & $\begin{array}{l}\text { Understanding one-to-many } \\
\text { unfamiliar face matching in the } \\
\text { operational context: The impact of } \\
\text { candidate list size, expertise, and } \\
\text { decision aids on the performance of } \\
\text { facial recognition system users }\end{array}$ & $\begin{array}{l}\text { Carolyn } \\
\text { Semmler, Brett } \\
\text { McLindin and } \\
\text { John Dunn }\end{array}$ \\
\hline 2013 & $\begin{array}{l}\text { Diane Elizabeth } \\
\text { Hosking }\end{array}$ & $\begin{array}{l}\text { Lifetime diet and cognition in older } \\
\text { people }\end{array}$ & $\begin{array}{l}\text { Vanessa } \\
\text { Danthiir, } \\
\text { Carlene Wilson } \\
\text { and Ted } \\
\text { Nettelbeck }\end{array}$ \\
\hline
\end{tabular}




\begin{tabular}{|c|c|c|c|}
\hline 2013 & Laura Jones & $\begin{array}{l}\text { 'If you don't manage diabetes it will } \\
\text { manage you': Type two diabetes self- } \\
\text { management in rural Australia }\end{array}$ & $\begin{array}{l}\text { Shona Crabb, } \\
\text { Deborah } \\
\text { Turnbull and } \\
\text { Melissa Oxlad }\end{array}$ \\
\hline 2013 & Nadja Klafke & $\begin{array}{l}\text { Interpersonal factors impacting } \\
\text { the decision to (continue to) use } \\
\text { complementary and alternative } \\
\text { medicine (CAM) in men with cancer } \\
\text { - A mixed-methods study }\end{array}$ & $\begin{array}{l}\text { Jaklin Eliott, } \\
\text { Gary Wittert } \\
\text { and Ian Olver }\end{array}$ \\
\hline 2014 & $\begin{array}{l}\text { Reza } \\
\text { Abdollahnejad }\end{array}$ & $\begin{array}{l}\text { Psychiatric disorders, cognitive } \\
\text { distortions and substance use } \\
\text { disorders in pathological gamblers }\end{array}$ & $\begin{array}{l}\text { Paul Delfabbro, } \\
\text { and Linley } \\
\text { Denson }\end{array}$ \\
\hline 2014 & $\begin{array}{l}\text { Pasquale K } \\
\text { Alvaro }\end{array}$ & $\begin{array}{l}\text { The bidirectionality of the } \\
\text { relationship between insomnia, } \\
\text { anxiety and depression in adolescents: } \\
\text { A longitudinal study }\end{array}$ & $\begin{array}{l}\text { Rachel Roberts } \\
\text { and Jodie } \\
\text { Harris }\end{array}$ \\
\hline 2014 & Peta Callaghan & Science, ideology and climate change & $\begin{array}{l}\text { Martha } \\
\text { Augoustinos } \\
\text { and Gail } \\
\text { Moloney }\end{array}$ \\
\hline 2014 & $\begin{array}{l}\text { Ashley Kathryn } \\
\text { Day }\end{array}$ & $\begin{array}{l}\text { Determinants of sun-related } \\
\text { behaviours in young adults: The } \\
\text { role of knowledge, sociocultural } \\
\text { influences, and appearance ideals }\end{array}$ & $\begin{array}{l}\text { Carlene Wilson, } \\
\text { Rachel Roberts } \\
\text { and Amanda } \\
\text { Hutchinson }\end{array}$ \\
\hline 2014 & $\begin{array}{l}\text { Laura Catherine } \\
\text { Edney }\end{array}$ & $\begin{array}{l}\text { Subjective wellbeing in healthy, } \\
\text { community-dwelling, older adults: } \\
\text { Measurement operationalisations } \\
\text { and examination of folate, vitamin } \\
\text { B12, homocysteine and omega-3 } \\
\text { polyunsaturated fatty acids as } \\
\text { potential predictors }\end{array}$ & $\begin{array}{l}\text { Vanessa } \\
\text { Danthiir and } \\
\text { Nick Burns }\end{array}$ \\
\hline 2014 & $\begin{array}{l}\text { Nicholas Francis } \\
\text { Hamm }\end{array}$ & $\begin{array}{l}\text { State-trace analysis of associative } \\
\text { recognition: Comparing single- } \\
\text { process and dual-process models }\end{array}$ & $\begin{array}{l}\text { John Dunn and } \\
\text { Anna Ma- } \\
\text { Wyatt }\end{array}$ \\
\hline
\end{tabular}




\begin{tabular}{|c|c|c|c|}
\hline 2014 & Adam Kane & $\begin{array}{l}\text { Response latencies to chromatic and } \\
\text { achromatic visual stimuli }\end{array}$ & $\begin{array}{l}\text { Anna Ma- } \\
\text { Wyatt and } \\
\text { David } \\
\text { O'Carroll }\end{array}$ \\
\hline 2014 & Emma Kemp & $\begin{array}{l}\text { Measuring children's forgiveness: } \\
\text { Development of the children's } \\
\text { forgiveness card set }\end{array}$ & $\begin{array}{l}\text { Peter Strelan } \\
\text { and Rachel } \\
\text { Roberts }\end{array}$ \\
\hline 2014 & $\begin{array}{l}\text { Nylanda Lai- } \\
\text { Han Tsang Ma }\end{array}$ & $\begin{array}{l}\text { The mental health and wellbeing } \\
\text { of siblings of children with mental } \\
\text { health problems: Two decades of } \\
\text { research }\end{array}$ & $\begin{array}{l}\text { Rachel Roberts, } \\
\text { Helen Winefield } \\
\text { and Gareth } \\
\text { Furber }\end{array}$ \\
\hline 2014 & Heather Pearce & $\begin{array}{l}\text { The identification and measurement } \\
\text { of barriers to forgiveness following an } \\
\text { interpersonal transgression }\end{array}$ & $\begin{array}{l}\text { Peter Strelan } \\
\text { and Nicholas } \\
\text { Burns }\end{array}$ \\
\hline 2014 & $\begin{array}{l}\text { Teresa } \\
\text { Puvimanasingh }\end{array}$ & $\begin{array}{l}\text { Surviving, striving, and thriving: } \\
\text { A qualitative study with former } \\
\text { refugees and their service providers in } \\
\text { Australia }\end{array}$ & $\begin{array}{l}\text { Linley Denson, } \\
\text { Martha } \\
\text { Augoustinos } \\
\text { and } \\
\text { Dayanandan } \\
\text { Somasundaram }\end{array}$ \\
\hline 2014 & $\begin{array}{l}\text { Joanne Siu } \\
\text { Chern Tan } \\
\text { Soosai }\end{array}$ & $\begin{array}{l}\text { A cross-cultural perspective on ageing } \\
\text { well in Australia: A mixed methods } \\
\text { approach to successful ageing and } \\
\text { filial piety among Anglo-Australians } \\
\text { and Chinese immigrants }\end{array}$ & $\begin{array}{l}\text { Lynn Ward and } \\
\text { Tahereh Ziaian }\end{array}$ \\
\hline 2014 & $\begin{array}{l}\text { Nicola Caroline } \\
\text { Vincent }\end{array}$ & $\begin{array}{l}\text { Evolving consciousness in leaders: } \\
\text { Promoting late-stage conventional } \\
\text { and post-conventional development }\end{array}$ & $\begin{array}{l}\text { Neil McAdam, } \\
\text { Lynn Ward and } \\
\text { Linley Denson }\end{array}$ \\
\hline 2015 & Adella Bhaskara & $\begin{array}{l}\text { Differential effects of confirming } \\
\text { post-identification feedback on } \\
\text { eyewitness testimony-relevant } \\
\text { judgments }\end{array}$ & $\begin{array}{l}\text { Carolyn } \\
\text { Semmler and } \\
\text { Neil Brewer }\end{array}$ \\
\hline 2015 & Amaya Gilson & $\begin{array}{l}\text { Potential futures: An ethnography } \\
\text { of a familial cancer counselling and } \\
\text { genetic testing unit }\end{array}$ & $\begin{array}{l}\text { Anna Chur- } \\
\text { Hansen, Shona } \\
\text { Crabb and } \\
\text { Susan Hemer }\end{array}$ \\
\hline
\end{tabular}




\begin{tabular}{|c|c|c|c|}
\hline 2015 & $\begin{array}{l}\text { Dinis Sequeira } \\
\text { Do Couto } \\
\text { Gokaydin }\end{array}$ & The structure of sequential effects & $\begin{array}{l}\text { Dan Navarro, } \\
\text { Amy Pefors and } \\
\text { Anna Ma- } \\
\text { Wyatt }\end{array}$ \\
\hline 2015 & $\begin{array}{l}\text { Danica Wai Yee } \\
\text { Liu }\end{array}$ & $\begin{array}{l}\text { An exploration of resilience and } \\
\text { suicidality across three age groups } \\
\text { in males and females living in the } \\
\text { community }\end{array}$ & $\begin{array}{l}\text { Rachel Roberts, } \\
\text { Richard Burns, } \\
\text { Karin Anstey } \\
\text { and Kate } \\
\text { Fairweather- } \\
\text { Schmidt }\end{array}$ \\
\hline 2015 & $\begin{array}{l}\text { Sonia } \\
\text { Masciantonio }\end{array}$ & $\begin{array}{l}\text { Mothering and mental illness: An } \\
\text { ethnography of attachment in an } \\
\text { institutional context }\end{array}$ & $\begin{array}{l}\text { Anna Chur- } \\
\text { Hansen and } \\
\text { Susan Hemer }\end{array}$ \\
\hline 2015 & $\begin{array}{l}\text { Brennan Zehao } \\
\text { Ong }\end{array}$ & $\begin{array}{l}\text { A psychological approach to } \\
\text { understanding and resisting the } \\
\text { influence of advertising from the } \\
\text { pharmaceutical industry }\end{array}$ & $\begin{array}{l}\text { Carolyn } \\
\text { Semmler and } \\
\text { Peter Mansfield }\end{array}$ \\
\hline 2015 & $\begin{array}{l}\text { Benjamin James } \\
\text { Robert Stewart }\end{array}$ & $\begin{array}{l}\text { The progression and management } \\
\text { of depression and anxiety in chronic } \\
\text { Hepatitis C patients }\end{array}$ & $\begin{array}{l}\text { Deb Turnbull, } \\
\text { Antonina } \\
\text { Mikocka- } \\
\text { Walus and Jane } \\
\text { Andrews }\end{array}$ \\
\hline 2015 & $\begin{array}{l}\text { James } \\
\text { Thompson }\end{array}$ & $\begin{array}{l}\text { Road safety and mobility of older } \\
\text { drivers in rural versus urban areas }\end{array}$ & $\begin{array}{l}\text { Matthew } \\
\text { Baldock, Jane } \\
\text { Mathias and } \\
\text { Lisa Wundersitz }\end{array}$ \\
\hline 2015 & $\begin{array}{l}\text { Melanie } \\
\text { Suzanne Turner }\end{array}$ & $\begin{array}{l}\text { The experience of the neonatal } \\
\text { intensive care unit (NICU) and } \\
\text { NICU supportive interventions }\end{array}$ & $\begin{array}{l}\text { Anna Chur- } \\
\text { Hansen and } \\
\text { Helen Winefield }\end{array}$ \\
\hline 2015 & Alexis Wheeler & $\begin{array}{l}\text { Associations between depression and } \\
\text { coronary heart disease }\end{array}$ & $\begin{array}{l}\text { Michael Proeve } \\
\text { and Linley } \\
\text { Denson }\end{array}$ \\
\hline
\end{tabular}


Plans for the new Graduate Diploma in Psychology were first introduced during 2006. The genesis for this development was a conversation between Ted Nettelbeck and Professor Neil Brewer, then head of the School of Psychology at Flinders University, at a national meeting of the Heads of Departments and Schools of Psychology Association [HODSPA]. Kirby outlined funding benefits that followed offering such a program, designed as a fee-paying, one-year qualification for bachelor graduates in other fields who now wished to consider a change to a career in psychology. Nettelbeck committed to emulating the lead of Flinders University and set about developing a program that could be offered in the following year, whereby a first-year introductory psychology course could be completed where required during the January-February vacation, with second-year and third-year courses completed during the first and second semesters. Thanks largely to the herculean efforts of Carmen Rayner, the Student Liaison Officer in the school, the new fee-paying program was in place, with accreditation for entry into honours, from the beginning of 2007 , commencing with five students. Thereafter enrolments increased dramatically, peaking at thirty-six for 2001, but with 161 graduates before 2015 .

Subsequently, the program was renamed the Bachelor of Psychological Science with a Graduate Entry because, consisting as it did only of bachelor-level content, the original name did not comply with the Australian Quality Framework's requirements for postgraduate study. Fifty of these graduates went on to successfully complete honours at Adelaide, the essential pathway to a career in psychology, and, of these, twenty-three to date have progressed to postgraduate master's, $\mathrm{PhD}$ or combined $\mathrm{PhD} /$ master's degrees.

\section{Professor Deborah (Deb) Turnbull (2007-10)}

Professor Turnbull completed her undergraduate studies at the University of Newcastle, where she also completed her Master of Clinical Psychology, before graduating in 1992 with a PhD from the Department of Public Health at the University of Sydney. She joined the University of Adelaide in 1995, as a lecturer in health promotion in the Department of Public Health, moving in 1999 to the Department of General Practice and then to psychology in 2005, when she was awarded a chair. Turnbull's primary areas of research fall under the umbrellas of health psychology and women's health, including public health, health promotion and clinically relevant research on breast and colorectal cancer screening, as well as work in perinatal and maternal health. Turnbull served as deputy head for Professor Ted Nettelbeck following the untimely death of Professor Doug Vickers. She became head of school on 1 January 2007, with her term ending in June 2010.

Her approach to the role accorded with the changes that had been underway for some time, whereby the autocratic style of leadership expected of a head had evolved 
to become far more consultative. However, she was also sensitive to how the role of head of school, whilst still consultative in nature, had changed from being primarily an allocator of funds, to being a political advocate, fighting for recognition and funding. The head was required not only to lead within the school, but also to represent, defend and advocate for the school at faculty and university levels as well as more broadly in the community and within the profession. This change of role needs to be understood in the context of the changing nature of tertiary institutions over 2000-15, including quite substantial changes to the expectations for academic scholars and the increasingly managerial nature of universities. In addition, the competition to attract increasing numbers of local, national and international students of high quality, as well to increase research funding, and also to attract staff with internationally recognised research profiles, had become progressively more fierce.

Professor Turnbull's period as head included a number of significant achievements as well as some substantial changes. She was the first head to seek an outside consultant to forge a strategic plan for the school and, while Ted Nettelbeck's deputy, had contributed significantly to their first attempt to develop a formal plan. Reflective of her interdisciplinary bent in research and in keeping with her collaborations in Public Health and Medicine, Turnbull was as an excellent networker, aiming to foster relationships between psychology and other disciplines within the faculty. A direct consequence of this approach was the implementation of the Master of Psychology (Health) degree, an initiative involving psychology, the discipline of psychiatry in the School of Medicine (via Anna Chur-Hansen, of whom more later), and the School of Population Health and Clinical Practice. The Master of Psychology (Health) can be viewed as an especially important contribution in light of the fact that, throughout Australia, postgraduate psychology training was becoming increasingly homogeneous, with an emphasis on clinical psychology at the expense of other areas.

Numbers in undergraduate psychology, particularly in the introductory first year, continued to grow during Professor Turnbull's time as head. Moreover, the number of honours places had by now increased to sixty Full-Time Equivalent [FTE] places, a number that would have been unthinkable a decade earlier. However, astute recruitment of suitably qualified affiliate staff, as well as wider research collaborations with staff elsewhere within the faculty, meant that these changes could be accommodated. The growth of numbers in class size saw a need for expanded teaching space, and Turnbull was successful in securing funding for the rebuilding and refurbishment of old tutorial rooms on Level 3 of the Hughes building, so as to create a new lecture theatre to accommodate honours classes. She was also successful in expanding the space allocated to the Centre for the Treatment of Anxiety and Depression [CTAD] at Thebarton, thereby increasing the opportunities there for field placements for master's students in the clinical and health programs. Ngartunna Wiltanendi (also known as the Northern Child and Family Clinic), Kaurna for Children Growing Stronger, was a collaboration 
between the South Australian Department for Education and Child Development and the University of Adelaide, which opened during Turnbull's time as head, and which provided further training places for students in the Clinical training program.

Equity and diversity were two principles to which Turnbull strongly subscribed. In 2008, she appointed Yvonne Clark, an Indigenous clinical psychologist, to a continuing lecturing position through the vice-chancellor's Indigenous Employment Strategy. Turnbull was also very keen to increase the number of international students in psychology at the University of Adelaide, and sought to develop offshore teaching, although the latter initiative did not eventuate. Although the role of professional staff within departmental/school committees had long been recognised as essential, Turnbull was the first head to recognise the importance of the knowledge and expertise that professional staff could bring to matters affecting the functioning of the school within the wider university, by expanding their roles to membership on faculty committees.

At the end of 2009, the school's in-house computing services were taken over by the university's central Information Technology Services [ITS]. As a consequence, Bob Willson and Mark Brown, both long-serving members of professional staff, retired. As a new computing science graduate, Willson had first joined the department in 1970, as a research assistant employed under an ARC grant (Welford, Vickers, McNicol), which purchased the first computer used in the department. This was a PDP 8L, which had $4 \mathrm{~K}$ of memory - a capacity that would surely utterly bemuse today's students. The machine was encompassed within a case about the size of a small refrigerator; it functioned by way of a high-speed paper tape reader and flip-chip modules; and it serviced a KV8L display for generating arrays of lines useful for designing stimuli in psychophysical experiments. Initially slowly, this humble beginning was expanded to permit the introduction of computing services into practical teaching.

Willson became a full-time member of staff and by the mid-1970s students were participating in departmental research activities and completing practicals that were computer-generated. By this time, the department had purchased a larger machine, a PDP 11, which had $16 \mathrm{~K}$ of memory, thereby enabling the simultaneous operation of sixteen Skinner boxes - the basis from which developed the celebrated first year 'rat prac', which paired every first year student with a Norwegian hooded rat (rattus norvegicus) that duly demonstrated the fundamental principles of shaping and learning. During these years the production and maintenance of Skinner boxes formed a major part of the workshop's activities. These machines, housed in modified Esky boxes, were designed and almost entirely built in-house, although the feeders were bought in, and they remained for years a testament to the high skills of the workshop staff.

These activities, supported by academic staff who included Tony Winefield and Peter Glow, but principally Frank Dalziel, expanded to a point where considerable resources for annually replenishing the animals, housing, feeding and watering were 
required to maintain them. A long succession of staff were employed to this end: Robyn Meyer, Bronwyn Priess, Leslie Bormand and Lynda Klopp, who later completed retraining in ITS and who left the school after twenty-five years of outstanding service. All first-year students were familiar with various schedules of operant conditioning; second-year students were introduced to more complicated manipulations; and third-year students graduated to observational studies, frequently of primates, within the Zoo. It was probably these aspects of the curriculum at Adelaide that gave rise to the oft-quoted and still encountered remark that psychology at Adelaide 'is all stats and rats'. Statistics and methodology continue to be essential to the training of psychologists, although they have only ever constituted a small proportion of the curriculum, and animal learning did provide an important aspect of training in psychology for many years; but there has not been a rat in the school for almost twenty years.

The second generation of computers introduced into the department in the early 1980s were CPM machines in the Z80 class: they were free-standing and sufficiently small to be portable. They were widely used by $\mathrm{PhD}$ students and academic staff, and the department for many years owned a caravan, fitted out as a mobile laboratory, which could be moved easily to locations off-campus where research projects were in progress. During this time, computing services were expanded by sundry appointments of varying duration, including Roger Harrington, Peter Barnes, Kustus Tiivas, David Knight and Tarmo Rohtla; but Mark Brown, first employed in 1981 as a research assistant to Peter Glow, was to spend almost thirty years providing invaluable programming support to academic staff who relied on his programming expertise to realise their research aims.

By the start of the 1990s, computing in psychology was a major aspect of the department's teaching and research activities, which required a substantial annual maintenance budget. The department now had sufficient machines to run three tutorial laboratories in parallel, with individual machines on every academic's desk, and eventually for all $\mathrm{PhD}$ students, all networked and controlled by the department's own server. In all, somewhere around 250 to 300 machines were involved. This was the system that the university's ITS took over, from 2008 through 2009. Willson retired to take up in part a project with David Knight whereby they have set out to restore to operating order a number of PDP 8Ls that are forty years old, although both Willson and Brown have until recently continued to undertake small contracts for the school.

\section{Professor John Dunn (2010-13)}

John Cameron Dunn, who had served as Deputy for Professor Turnbull, was head of the School of Psychology from 2010 (the year in which he became a full professor) to October 2013. He completed his undergraduate studies and doctorate in psychology at the University of Western Australia. Previously at the University of Western Australia's 
School of Psychiatry and Clinical Neurosciences, he came to the University of Adelaide in 2006. He was looking for a challenge and wanted to work with fellow psychologists, and to build a research group in cognitive science that included postgraduate students. An additional attraction was that his colleague, Simon Dennis, who had previously worked with Dunn and who had cognate interests, was already working in the school. As already described above, Dennis moved to Ohio State University eighteen months after Dunn arrived, although the collaboration has continued. Dunn was chair of HODSPA from 2011 to 2014, and since 2015 has been chair of the Australian Psychology Accreditation Council [APAC].

Dunn's style of leadership differed from Professor Turnbull's. Whereas she had endeavoured to facilitate growth, he tended to focus more on consolidation. As part of his role, he oversaw refurbishment of the Hughes building, including the ground floor, encompassing reception and professional staff offices. Meanwhile, consideration of the strategic plan for the School of Psychology developed under Professor Dunn shows continued acceptance of, and respect for, the diversity that Professor Taplin had instigated and that was evident in Professor Turnbull's earlier strategic plan. The experimental, scientific aspect of psychology and the professional domains were both clearly represented, with a broad disciplinary base and both theoretical and applied research highly valued. Three research groupings, initially devised by Douglas Vickers and introduced by Ted Nettelbeck, were maintained, reflecting the diversity of the school's teaching and research: health, disability and lifespan (in which currently a majority of staff and higher degree students identify); brain and cognition ('the coggies'); and social and organisational psychology.

The breadth of research methodologies that are embraced by this description distinguishes the school; they include qualitative methods such as conversation and discourse analysis, thematic analysis, computational mathematics, cognitive science and experimental psychology, amongst other approaches. The quality of the research of the school continued to increase over successive years. Based on the Excellence in Research for Australia [ERA] rankings, whereby quality ratings are calculated against national and international benchmarks, the school scored 3 out of 5 (an average world ranking) in 2011, when the rankings were first reported. By the second round in 2012, however, the school had achieved a 4, and by 2015 it was on the cusp of a 5. During Dunn's headship, the university required all courses to be unitised (to be worth three units of course credit out of twenty-four units for a full academic year load) - a major undertaking. As part of unitisation, all courses were strategically linked to one of the three research groupings, making explicit the teaching/research nexus.

Within the master's professional training programs, the leaning towards a mixed portfolio was also evident. The school resisted the trend apparent in most other schools of psychology around Australia to offer only clinical training at postgraduate level, maintaining offerings in four different pathways. In addition to the Master of Psychology 
(Health), the school has offered the Master of Psychology (Organisational and Human Factors), which commenced in 2002, following on from the Master of Psychology (Clinical), as well as a master's program in collaboration with the Australian Defence Force (see below). To support the placements required for postgraduate professional training, internal supervisors holding registration as psychologists, particularly clinical qualifications, were needed. In 2012, funding from Health Workforce Australia [HWA] provided posts for Dr Michael Proeve (who had previously co-ordinated forensic psychology at the University of South Australia), Dr Diana Dorstyn and Dr Anthony Venning. The Playford Superclinic was opened in 2011, with a dedicated psychologist appointed to supervise placements for Health and Clinical students.

Professor Nicholas (Nick) Burns (who joined the staff in February 2000), served as deputy head for John Dunn, and in addition to several shorter periods, for a continuous period of around six months, was acting head of the school, while Dunn pursued scholarly work at the Chinese Academy of Sciences, an opportunity opened up by the visit to the school of Professor Jiannong Shi from August to October 2005. Professor Turnbull, as part of her strategic plan, had attempted to mount a Master of Applied Psychology (Defence) — later named the Master of Clinical Psychology (Defence) - and Professor Dunn continued to drive this forward. Professor Burns ultimately achieved this goal, with the first intake commencing in 2011. This program was offered in conjunction with Joint Health Command, Australian Defence Force [ADF], and open only to personnel with an honours degree in psychology, working in the ADF. Burns must also be recognised for his key role in arguing for an increase in staffing, by illustrating that the school had violated the accreditation rules for staff-to-student ratios. With too many students and insufficient staff to teach them, two posts were advertised and Dr Matthew Dry and Dr Irina Bateau were appointed in 2011, both with research interests in fields of brain and cognition.

Professor Burns also served as Associate Dean (Information and Technology) for the Faculty of Health Sciences. In an effort to address the increasing pressures associated with managing enrolments of around 700 in first-year psychology, he and Dr Clemence (Clemmi) Due worked towards a blended model of teaching that included online delivery of part of the curriculum and (somewhat controversially) the deletion of all tutorials. In recognition of this initiative, they were awarded the Executive Dean's Teaching Prize in 2012.

\section{Professor Anna Chur-Hansen (since 2013)}

Anna Chur-Hansen studied a Bachelor of Arts at the University of Adelaide, majoring in psychology 1981-83. She entered honours psychology in 1984, and in what was to be a pivotal decision, chose as her thesis supervisor, Dr Marilyn Peay, from the Department of Psychiatry in the School of Medicine. As a result of this collaboration, 
she went on to become an academic staff member in psychiatry, working there from early 1987 through to 2013. She became acting head of psychiatry in 2007, the first non-psychiatrist to serve in that role, and served as such periodically for several years. She also became a registered psychologist, with an endorsement in health psychology. Her doctoral thesis was in medical education, with a particular focus on a group of medical students who studied under the Malaysia-Australia Tertiary Education Scheme [MATES], which ran from 1987-99.

Whilst Chur-Hansen had left psychology to join the School of Medicine, she always maintained connections with her home discipline, through friendships with colleagues, collaborations on various projects, and through students. Her colleague, friend and mentor, Professor Helen Winefield, also working in psychiatry, was a particularly strong tie to the profession and discipline of psychology. Chur-Hansen commenced a three-year term as head of the School of Psychology in October 2013, after being invited to apply for the role by the executive dean, Professor Justin Beilby. For the first time in the school's history, she appointed two deputy heads, Professor Paul Delfabbro (to assist with strategy and implementation in learning and teaching) and Professor Jane Mathias (to assist with strategy and implementation in research).

Chur-Hansen's time in the role has been challenging thus far. She began her term with a significant budget deficit; moreover, further changes and shifts in teaching philosophy and methods have occurred with little or no additional resourcing. Learning methods, including online teaching, have been introduced, and opportunities have been created for students to study abroad. Academic performance expectations have been reframed, and changes to the way professional services are to be delivered mean that the administrative team currently located within the school will be reallocated within the Faculty of Health Sciences.

It is too early to speculate about what such changes will mean for the school; but, given a history of sixty years of exceptional achievements, one can afford to be optimistic that psychology will continue to be a significant and valued contributor to the Faculty of Health Sciences, the university and the wider community, with the staff and students well respected by their medical, nursing, dental and public health colleagues. At the time of writing, staff currently employed within the school are as set out in Table 3.2 . 
Table 3.2 Snapshot of staff in the School of Psychology as at November 2015 (including staff on contracts and on research fellowships).

Source: Author's own work.

Academic staff

Professor Anna Chur-Hansen — Head of School

Professor Paul Delfabbro — Deputy Head of School (Teaching and Learning)

Professor Jane Mathias — Deputy Head of School (Research)

Professor Martha Augoustinos

Dr Irina Baetu - Lecturer

Professor Nick Burns

Ms Yvonne Clark - Lecturer

Dr Simon De Deyne — Research Fellow

Dr Linley Denson — Senior Lecturer

Dr Diana Dorstyn - Lecturer

Dr Matthew Dry - Lecturer

Dr Clemence Due - Lecturer

Professor John Dunn

Dr Julia Harries — Senior Research Associate

Dr Daniel King - Research Fellow

Dr Angela Kinnell — Lecturer

Dr Neil Kirby — Senior Lecturer

Associate Professor Amanda LeCouteur

Associate Professor Anna Ma-Wyatt

Professor Philip Mohr

Dr Jane Mortimer — Senior Lecturer

Associate Professor Daniel Navarro

Emeritus Professor Ted Nettelbeck

Associate Professor Amy Pefors — Research Fellow

Dr Michael Proeve — Senior Lecturer

Dr Rachel Roberts - Senior Lecturer

Dr Aspa Sarris — Senior Lecturer

Dr Carolyn Semmler — Senior Lecturer

Dr Peter Strelan — Senior Lecturer 
Professor Deborah Turnbull

Dr Lynn Ward — Senior Lecturer

Professor Helen Winefield

Professional staff

Angela Allen — Senior Finance and Purchasing Officer

Karen Davies - Master's Placement Supervisor, Uni Health Playford

Lynda Klopp — Learning \& Teaching Officer

Kylie Pollitt — PA to Head of School

Wanda Prokopiak — Test Librarian and Administrative Assistant

Carmen Rayner - Student Liaison Officer

Carola Sanders — School Manager

Deidre Simpson — Administrative Assistant

Jessica Venning — Senior Administrative Officer

Kari Walsh — Clinic Director, Families SA Northern Child and Family Clinic

Dr Leah Wilson — Senior Research Associate

\section{Acknowledgements}

Preparation of this chapter was informed by interviews with Neil Kirby, John Dunn, Deborah Turnbull, Carola Sanders, Carmen Rayner, Lynda Klopp and Bob Willson. John Taplin, Christopher Cooper, Ted Nettelbeck Steve Tupper and John Brebner provided written input. I am indebted to them for their reflections. 


\title{
Teaching applied psychology at the University of Adelaide: A personal view
}

\author{
Neil Kirby
}

The beginning of applied psychology training in South Australia

In 1974 the introduction of the Diploma in Applied Psychology marked a major change in the teaching and research within the then Department (now School) of Psychology at the University of Adelaide. Prior to that time, the Department of Psychology had been almost entirely experimental in its approach to psychology, exemplifying the 'rats and stats' tag given by students to the subject. The 'stats' tag was to endure to the present time, but 'rats' ended in 1996 with the phasing out of practicals using rats in 'Skinner boxes', which had been organised for many years by Frank Dalziel to demonstrate operant conditioning principles.

Before 1974, the major division within the teaching of psychology in the department was not, as it is now, between theoretical and applied psychology, but between experimental and social psychology. A general first-year course was followed by Psychology $2 \mathrm{~A}$ and then $3 \mathrm{~A}$, which involved topics like cognition and animal behaviour, and by Psychology $2 \mathrm{~B}$ and then 3B, which included developmental and social psychology. In neither type of course was there any practical training in how to apply psychology within the community. The A and B streams of psychology were eventually combined into a single second-and third-year course, still without the inclusion of any training in the application of psychology. The third year in psychology was followed by an honours year, again with an experimental focus, and the honours year prepared students interested in research for a PhD in experimental psychology.

The circumstances that led to the Diploma in Applied Psychology began with what became known as the Anderson report (Anderson, 1965), after the state of Victoria 
set up a Board of Inquiry to investigate complaints about Scientology. The report investigated complaints concerning the practice of Scientology and, in particular, its use of what were considered by the report to be pseudo-psychological assessments using an $\mathrm{E}$ meter. The E meter measured galvanic skin response, but Scientologists used it to diagnose psychological conditions as part of a process designed to recruit often-unsuspecting members of the public to the practice of Scientology. The review recommended legislation that would ban Scientology and set academic training requirements for the use of the term 'psychologist'. This legislation was enacted in 1967 but was subsequently amended in 1982 to remove any reference to Scientology; it was repealed in 1987.

However, other states were also concerned about people such as Scientologists acting as psychologists without having had any formal academic training in psychology. This led these states to enact similar legislation concerning the training requirements for being a professional psychologist but without referring specifically to Scientology. In South Australia, the legislation came into force in 1973 and required a progressive three-year course of study in psychology at a university, and not less than three years of experience working as a psychologist, which was considered sufficient evidence of competence to practise psychology. The legislation included a 'grandfather clause', which allowed those who had already completed sufficient study, and had been working as psychologists before the commencement of the act, to be registered. The Diploma in Applied Psychology was set up in 1974 as a fourth year of study which provided instruction in the application of psychology. A fourth year of academic study followed by two years of supervised experience subsequently became a requirement for registration.

The completion of a three-year degree in experimental psychology as a requirement for entry into the Diploma in Applied Psychology was consistent with the proposal of Lightner Witmer more than 100 years ago for a profession of clinical psychology that would require its (scientist) practitioners to have rigorous training in the scientific methods used in experimental psychology (as cited in Hergenhahn, 2009). Witmer's proposal was published in 1907 in an article entitled 'Clinical psychology' in the first edition of the journal The Psychological Clinic, which he founded. Another early proponent of a scientific applied psychology was Hugo Munsterberg, who in 1913 published Psychology and industrial efficiency. In this book (2012/1913), he promoted 'a new science' that could contribute significantly to the improved performance of organisations.

It is only relatively recently that questions have been raised (for example, as indicated in the recent green paper from the Psychology Board of Australia, 2015) about why it should require so many years of study to become a professional psychologist, and accordingly why there should be so much theoretical training before learning to apply psychology. 


\section{Applied psychology before the diploma program at the University of Adelaide}

Many of the skills taught in the diploma program — such as clinical interviewing, counselling, training and psychological assessment - were already being applied in the community as a result of training courses or supervised practice in government, education and commercial organisations. It was for this reason that legislation for registration allowed for the inclusion of those who had already been practising as psychologists, without requiring them to complete additional supervised experience or professional training. Psychological tests like the Stanford-Binet and the Wechsler Adult Intelligence Scale [WAIS], which can now only be administered by a registered psychologist after completing a Master of Clinical Psychology or its supervised equivalent, were being used before registration and before the advent of the diploma, particularly in education and in government agencies. Those using such tests had been taught by someone within education, the government or a commercial organisation, or they had taught themselves to use such tests. This had led to some unprofessional behaviour in this regard. According to some anecdotes, one psychologist at the time the diploma was established was still using the original Wechsler Bellevue, which had been published in 1939, instead of the 1955 revision of the test. When asked how he managed the use of the outdated norms in his assessments, he had apparently indicated that he made mental adjustments concerning the IQs associated with particular scores on the test.

However, those practising as psychologists before registration and the diploma course did have the advantage of being able to advocate for, and act in the best interests of, their clients before being increasingly constrained by legal requirements associated with registration and other forms of legislation. I remember comments at a conference on disability in the 1990s from participants lamenting the fact that many leisure activities that were very beneficial for the development of independence and self-esteem in children and adults with disabilities (for example, activities involving physical exercise and cooking skills) could no longer be offered because of safety legislation and the consequent concerns of organisations about being sued if an accident occurred.

\section{Research in applied psychology: The Bedford Industries fellowship}

In 1972, not long before professional training in applied psychology began with the diploma program, there was a substantial increase in the potential for teaching and research on applied psychological topics in the Department of Psychology, as a result of a research fellowship in psychology. This fellowship was funded by Bedford Industries, a large rehabilitation centre situated at Panorama in Adelaide. The position involved working half-time as a lecturer in the Department of Psychology and half-time as a consultant psychologist at Bedford Industries. The lectureship aspect of the position involved some specific teaching on disability at the university. Meanwhile, the consultant 
role included working with management, staff and clients at Bedford Industries, plus supervising research that involved honours, diploma, $\mathrm{PhD}$ and subsequently, after the discontinuation of the diploma in 1988, master's programs students. The fellowship was created and funded by Bedford Industries as a result of discussions at that time between the then director of Bedford Industries, Kenneth Jenkins, and the head of the Department of Psychology, Professor Alan Welford.

In addition to the establishment of the Bedford Industries research fellowship, Bedford Industries also funded a professorship in rehabilitation in the Department of Medicine at the Flinders University of South Australia. Dennis Smith was appointed to that position and he also served on the Board of Bedford Industries.

The first person to be appointed to the research fellowship was Ted Nettelbeck, and then, in 1974, when he became a full-time lecturer in the Department of Psychology, I was appointed to the position. I became a senior research fellow in 1983 and remained in that position until the research fellowship and the professorship in rehabilitation were both discontinued in 1991. I was then appointed to a full-time lectureship in the Department of Psychology, but went on to serve on the board of Bedford Industries until 2006, at which time a requirement for limited-term appointments to the board had been introduced. After retiring from the board, I was made a life member of Bedford Industries for my services to that organisation. After the professorship in rehabilitation was discontinued, Dennis Smith left Adelaide to take up a similar chair in rehabilitation medicine at the Northern Clinical School, associated with the University of Sydney.

Although Ted Nettelbeck had left the Bedford Research fellowship in 1974, he remained involved in teaching and research related to disability within the Department of Psychology in association with myself and research students. His continued involvement in disability also included contributions to other disability organisations, including serving on the board of Minda from 1977 to 1984 and on the Welfare Committee and the Services Advisory Committee of the Phoenix Society from 1978 to 1990 . From the Phoenix Society he received an award in 1990 for outstanding service to the organisation.

During my time as the Bedford Industries research fellow in the 1980s, I was also engaged in activities with other organisations which contributed to my teaching of applied psychology in the diploma program and in the subsequent master's programs. In particular, I served as a committee member in other organisations involved in disability, including Panorama TAFE, which had a committee concerned with the welfare of students with disabilities; I was a board member of SA Group Enterprises, an organisation set up by the Commonwealth Government to provide employment for people with severe disabilities, and which is now associated with Minda Incorporated; and I served on the eligibility review committee of the South Australian government's 
Intellectual Disability Services Council [IDSC]. Major problems in reviewing the eligibility of clients who had not been accepted into the service included determining whether the adaptive behaviours of adults had been sufficiently low during the developmental period to meet the intellectual disability criterion for entry, ${ }^{5}$ and deciding on the extent to which the additional mental health issues of some clients could be accommodated within the services provided by the agency. During this time, I also provided disability-related teaching in a course for sheltered workshop supervisors at Marleston TAFE and lectures on disability at the then Burwood College of Advanced Education in Melbourne.

Ted Nettelbeck and I continued to conduct and supervise research on disability throughout the 1990s, and in 2001, a Disabilities Research Unit [DRU] was established by John Taplin, who was the head of school at that time. Members of this unit included myself, as director, Ted Nettelbeck and John Taplin, who had also conducted disability research in other universities prior to his appointment as head of school. Research managers for various DRU research grants included Julia Harries, Roma Guscia and Leah Wilson. Computing assistance for assessment projects undertaken in the unit and funded by the state government was provided by Rakesh Chandrasekharan. In 2013, the unit was renamed the Wellbeing Research Unit [WRU] in order to include organisational research projects being funded by SafeWork SA on the work safety of Disability Support Workers. The DRU provided, and the WRU continues to provide, research opportunities for honours, master's and PhD students.

\section{Establishing an applied diploma program at the University of Adelaide}

At the time the Diploma in Applied Psychology was introduced as a fourth-year course in 1974, there were only three lecturers in the Department of Psychology who had any practical experience in applied psychology, as distinct from conducting research in applied areas of psychology. In the case of Ted Nettelbeck and myself, our practical experience was associated with disability, as a result of the establishment of the Bedford Industries research fellowship. However, working in the research fellowship initially involved more applied research and advice on service-related issues rather than the use of applied psychology techniques such as psychological tests. This meant that existing staff of the department who had been trained in experimental psychology, including Ted Nettelbeck and myself, had to acquire the knowledge and skills required to teach applied psychology to graduate students. For example, Ted Nettelbeck and I learnt together how to use the Wechsler Adult Intelligence Scale [WAIS], since neither of us, nor anyone else in the department, had been taught how to use it. In the first year of

5 That is, the intellectual disability criterion was based on three things: low intellectual ability, low adaptive behaviours, and evidence of these during the developmental period. 
the diploma program, our teaching each other how to give the Wechsler scales was only one or two weeks in advance of our teaching the students.

The appointment in the Department of Psychology of John Kaye in 1972 provided students in the diploma program with practical expertise in counselling psychology. Most of the remaining practical experience in the course came from psychologists working in the community at that time.

The content of the Diploma of Applied Psychology did not change markedly over the years for which it continued. The content of the course and the associated lecturers, as indicated in the handbook for the last year of the course in 1987, included counselling and psychotherapy (John Kaye), psychological assessment and measurement (Ted Nettelbeck and Neil Kirby), behaviour analysis and modification (Neville Owen, C Hart, Roslyn Glow, Eric Rump, Neil Kirby and Tony Winefield), applied social psychology (Michael Innes), educational psychology (JA Rowel and Maxine Sheppard), statistics and methodology (Peter Delin, Eric Rump and Robert Willson), and practical work, which included introductory interviewing (John Kaye and Neil Kirby), professional practice seminars, research seminars, placements (two, each of forty hours' duration) and visits (eight, each of two hours) to various agencies. There was also a research investigation or critical survey.

Practical instruction at that time was facilitated by the availability of video recording, so that students could complete exercises in courses like Introductory Interviewing and Counselling, which involved videoing themselves in pairs while performing an interview or brief counselling session. The resulting video could then be assessed with feedback provided by the course lecturer. However, the relative unfamiliarity of students at that time with such technologies meant that the equipment did not always work as intended. I remember giving a course in introductory interviewing in the diploma program in which pairs of students were required as a practical exercise to hand up a video in which they had interviewed each other according to guidelines provided in the lectures. On starting one particular video that had been handed in, I was surprised to find a student staring into the camera and asking the other student whether the video recorder had started. On being told that it had not, the student proceeded to ask the other student what it was they were required to do for the exercise, as she said that she had not gone to that particular lecture. The other student confessed that she was also uncertain about what was required as she had not bothered to take notes during the lecture, but she assured the other student that they would make something up that would be okay. The video then went off and on again several times until the students were satisfied that it was indeed recording, whereupon they attempted with appropriately serious expressions to interview each other, although with rather less than more expertise in terms of the requirements of the exercise!

The diploma course included visits to organisations where psychologists were working, and these visits often provided revealing insights into working conditions in 
different kinds of organisations. However, these visits sometimes produced unintended effects. On one particular visit, which was to the local abattoirs, some of the students and some of the accompanying staff (including myself) found that their own needs (for counselling concerning what they had witnessed on the production line) made it difficult to listen attentively to the psychologist at the site talking about dealing with the problems of workers and management.

\section{Master of Applied Psychology}

In 1988, the one-year Diploma of Applied Psychology program ended, and in 1989 it was replaced by a two-year Master of Applied Psychology. In 1991, this changed to a two-yearly intake, until 1996, when it became the Master of Psychology (Clinical). In 1997, it became the Master in Psychology (Clinical and Health); in 1999, the program changed to a yearly intake; and in 2000, it was renamed the Master of Psychology (Clinical).

The Master of Applied Psychology became an expanded version of the previous diploma program with some of its course topics later becoming part of the subsequent master's programs in clinical, organisation and human factors, and in health. The first year of the Master of Applied Psychology program included the following compulsory courses and associated lecturers: working with human systems - theory and practice (John Kaye, Geraldine Slattery, Helen Menses, Michael White), psychological assessment (Ted Nettelbeck, Neil Kirby, John Kaye), applied methodology (Peter Delin, Eric Rump and Robert Willson), applied social and organisational psychology (Michael Innes), behaviour management (Don Pritchard), professional practice and ethics (Eric Rump, Ian John, Roslyn Glow) and health and community psychology (Michael Innes). Optional courses, of which students were required to choose one, included educational psychology (Maxine Sheppard), ergonomics (John Brebner), disability, vocational training and assessment (Neil Kirby), psychology of unemployment (Tony Winefield), and rehabilitation psychology (Don Pritchard). The program changed relatively little over the seven years for which it operated (that is, from 1989 to 1996), although there were expanded options for placements at clinics in the community.

An advantage of the Master in Applied Psychology was that graduates from the two-year master's course would not only benefit from more instruction with respect to applied psychology but would also have the benefit of three extensive placements working with psychologists in the community. This would serve to enable them to achieve registration without the previously required two years of supervised professional practice by a registered psychologist.

However, the transition from the Diploma to the Master of Applied Psychology was not achieved without additional work by staff. I remember a particular staff meeting in which the then head of the department, Chris Cooper, announced, with respect to 
the proposed clinical program, that he had some good news and some bad news. The good news was that the program had been approved by the university administration; the bad news was that there would be no additional resources for the program.

\section{Master of Psychology (Clinical)}

The Master in Psychology (Clinical) in 1996 and the Master of Psychology (Clinical and Health) largely continued the curriculum of the Master of Applied Psychology. However, with the appointment in 1997 of Jeffery Richards, who had extensive practical experience in mental health, the program added a more clinical focus. Jeffery Richards taught adult clinical psychology; in addition, child clinical psychology and clinical neuropsychology were added to the program, the former being taught by a guest lecturer and the latter being taught by Jane Mathias. In 1999, the organisational and educational courses were taken out of the program. In 2000, the renamed Master of Psychology (Clinical) program had the following courses and course co-ordinators: adult clinical psychology (Helen Winefield), psychological assessment (Ted Nettelbeck), preparation for psychological practice (Jane Blake-Mortimer), child clinical psychology (Kathy Moar), health psychology (Helen Winefield), applied methodology (Eric Rump), group interventions and preventive practice (Jane Blake-Mortimer), clinical neuropsychology (Jane Mathias), rehabilitation and disability (Neil Kirby), and psychological and health aspects of ageing (Jan Harry).

Budgetary constraints on staff appointments meant that some of those lecturing in the program and in the previous clinical and health program came from clinical positions outside of the School of Psychology. A particularly important issue with respect to the accreditation of the program was the lack of a staff member with expertise in child development, an area that was introduced into the clinical and health program in 1997 . This was a requirement for full accreditation, and the course had to rely on external expertise in this area until the appointment of Lisa Kettler in 2003. Until that time, the course remained only provisionally accredited, and this continuing provisional accreditation eventually led to some disquiet amongst students as to whether the course would or would not continue because of this gap in the expertise required of teaching staff.

Current courses in the Master of Psychology (Clinical) program and associated course co-ordinators include evidence-based practice (Michael Proeve), interviewing and intervention (Yvonne Clark), psychological assessment (Rachel Roberts), abnormal psychology (Linley Denson), health psychology (Helen Winefield), clinical neuropsychology and disability (Jane Mathias), and advanced child and adult intervention (Diana Dorstyn). These courses now have individual contributions from many clinical psychologists working in the community. 
An important continuing contribution to the Master of Psychology (Clinical) has been the opportunity available to students to complete a supervised placement arranged with clinics outside of the university. These have included an outpatient clinic in the South Australian Mental Health Services, and currently include clinics at the Centre for the Treatment of Anxiety and Depression, which is part of SA Health, a university teaching health clinic associated with a General Medical Practice, and a clinic associated with Families SA, which is currently located within the Education Department.

\section{Master of Psychology (Organisational and Human Factors)}

The success of the diploma and clinical master's programs suggested that other similar master's programs might be offered. A major advantage of the existing clinical program in this regard was that there were common basic areas of psychological knowledge and skill, such as professional practice, which included ethics and basic interviewing, and these were required for accreditation of any type of applied psychology program leading to registration as a psychologist. This meant that there could be economies of scale through shared teaching topics in more than one master's program.

As the Bedford Industries research fellow, I was involved over a number of years in the two-year supervision of fourteen trainee psychologists with fourth-year degrees, who were working at Bedford Industries as rehabilitation officers. Ten of these trainee psychologists were graduates of the original diploma program at the University of Adelaide. During my time working at Bedford Industries and while supervising and working with these trainee psychologists, I became aware of the extent to which current psychological training lacked an awareness of, and expertise in dealing with, organisational issues related to working with clients and management.

An illustration of this organisational naïvety in the early work of the Bedford fellowship involved Ted Nettelbeck and me being called to the director's office over a research article we had written which referred to Bedford Industries as a sheltered workshop. We were informed in no uncertain terms that Bedford Industries was to be referred to as a rehabilitation centre and not a sheltered workshop - the reason for this being, as we later discovered, that rehabilitation centres received more government funding than sheltered workshops. Our mistake in terms of organisational politics was due to the fact that, although Bedford Industries did have rehabilitation programs for people who had suffered an accident or illness that required rehabilitation to enable them to return to work, many, if not most, of its clients with disabilities had never worked and were therefore cases of habilitation, and for many of them Bedford Industries was providing long-term sheltered employment. With respect to this issue of rehabilitation versus sheltered employment, I remember a rather disconcerting comment made by this Oxford-educated director on a subsequent occasion when, 
discussing my work at Bedford Industries and the university, he said, while leaning back in his chair: 'Ah yes, the university ... society's most sheltered workshop!'

While I was supervising trainee psychologists at Bedford Industries, it also became apparent to me that much of the work being carried out by the rehabilitation officers - which included assessment and induction of new clients; working in teams with managers and supervisors to place clients in appropriate jobs; conducting staff training; organising client training, work experience and jobs in open employment; program planning and evaluation; working with other professionals including nursing staff; and writing reports for management - had more to do with organisational psychology than with rehabilitation itself. It was also the case that the rehabilitation officers' work was strongly influenced by changes in disability service models such as deinstitutionalisation; activity therapy centres; work enclaves in commercial organisations; work preparation centres; supported employment in the community; specialised training programs for adults with severe disabilities; centres for day options; and the recent National Disability Insurance Scheme. Many of these programs and models were tried and replaced by subsequent models designed to improve quality-of-life outcomes for people with disabilities.

The work of rehabilitation officers was also strongly influenced by changes in government legislation with respect to disability, such as the Disability Services Act 1986 (Cth), with its emphasis on consumer participation in services and consumer outcomes, and the Disability Discrimination Act 1992 (Cth), with its emphasis on the rights of people with disabilities to housing, education and services. These changes in disability service models and government policies meant changes to the ways in which management, supervisors and other staff, including the psychology graduates as rehabilitation officers, worked with clients and with their families. In particular, it involved the rehabilitation officers in setting up and taking part in client representative and family representative committees, and it meant working with professionals in external services.

Of particular value with respect to the client representative committee was a process I initiated while I was a board member whereby a member of the board on a rotating basis attended one of these meetings each year. This enabled the client representatives to meet and question board members whom they had never met before, and it gave the board members an awareness of clients' issues within the organisation. In my time on the board, I noted a number of important issues for clients that were quickly dealt with as a result of their being mentioned by a board member who had attended a recent client representative committee, and it seemed to me that this arrangement of a board member attending worker committees on a rotational basis might be beneficial in most if not all organisations.

Changes in government policy reflected international changes in attitudes towards people with disabilities and the services provided for them. Of considerable 
influence in the 1960s, particularly with respect to deinstitutionalisation, was a report from President Kennedy's Presidential Panel of Mental Retardation (1962), which in 1963 resulted in legislation to increase research on, and improve services for, people with mental disabilities. In the 1970s, as part of a review of progress, senators from the US Congress were sent to different countries to investigate disability services, and I was involved in taking one of these senators from his hotel in Adelaide to Bedford Industries, where he was given a tour of the facilities. On returning to his hotel, we discussed improving disability services and he met my expressed concerns about difficulties in that regard with a forthright 'can-do' attitude: 'Listen', he said, 'this is our society and we can do whatever we want!' The outcomes of Kennedy's initiative, prompted partly by his own personal interest because of his sister Rosemary's mental health problems, were to have a major positive impact on disability services in the US and internationally.

However, the influence of government officials on disability services was not always particularly positive. A situation at a much later time, which I found difficult to comprehend, concerned feedback from a government official about what needed to be included in an application form for government funding for the employment services that Bedford Industries was providing. The government official stated that it was very important that organisations fill in the application form correctly and, to make the point, said that there were some employment agencies interstate that had been very successful in placing people with disabilities into open employment but had not had their funding renewed because they had not filled in the form correctly. Given the difficulties associated with achieving open employment for people with disabilities, it seemed incredible to me that such organisations should be discontinued because they had not filled in a form correctly. When I suggested that perhaps filling in forms was not the forte of such agencies and that it might be useful for the government to provide them with some assistance in this regard, the government official promptly said that it was not their job to provide that kind of assistance.

An example of assistance by the government for placing people in open employment was a computerised program in the 1980s which suggested a range of suitable jobs for people with different kinds of qualifications and skills. At Bedford Industries, most employees had very few qualifications and skills, so we were interested in what kinds of jobs might be suggested for the employees we were seeking to place in open employment. To test the limits of the program, we entered a fictitious person with no qualification and no skills, and to our surprise and delight there was only one job that was suggested: politician. Whether this was a joke by the programmers or democracy in action we were not able to determine.

As a result of my concerns about the importance of organisational issues with respect to disability, I introduced undergraduate courses on psychological assessment with an emphasis on work, and a course entitled Applied Behaviour Change and 
Training, which provided instruction on the use of behaviour management and training in work settings.

I also began to conduct and supervise research in organisational psychology. During my supervision of Liz Kummerow's PhD on organisational culture, she and Michael Thalbourne, a graduate, tutor and then research fellow in the Department of Psychology, contributed to the department's culture by organising an annual picnic for staff and students. This picnic, which in its first few years included live music, continued for ten years or more with the assistance of professional staff, including particularly Carmen Rayner, Robyn Meyer, Lynda Klopp, Bob Willson, Jeffrey Mathews and Steve Tupper. A large barbecue with a trough for coals was constructed in the department's workshop, where it was referred to in the job lists as an 'Otter bath'. The professional staff continued to support annual events of this kind until very recently when most of them were centralised with other professional staff in the Faculty of Health Sciences as part of a faculty restructure.

When John Taplin became head of department (after having been a student and tutor in the department many years before), it was decided to introduce a Master of Organisational Psychology. The program, which began in 2002, had the same format as the clinical program and other such programs nationally, in that it involved a first year of intense teaching on relevant topics plus one placement in the community during the second half of the first year, followed by two further placements and a research thesis in the second year.

As with the diploma course, there was an initial lack of teaching staff with experience in the practice of organisational psychology, and limited resources to appoint such staff, although research-related courses on organisational psychology and employment had been taught in the Master in Applied Psychology. Carlene Wilson, who was a visiting research fellow at that time, assisted in the development of the program and in the initial teaching of courses. I was able to bring my practical experience working as a consultant psychologist at Bedford Industries to the following courses in the first year of the program: professional and ethical practice, psychological assessment, individual and organisational change and development, and organisational behaviour and management. In the second semester of the first year of the program, assistance in the teaching was provided by Aspa Sarris, who had recently completed her $\mathrm{PhD}$ under my supervision on the topic of organisational culture and had previously worked in the South Australian government on policy-related issues.

Sarris also taught human resources management, with the other courses being presented by academics in the School of Psychology, including methodology and statistics (Paul Delfabbro), psychological assessment (Ted Nettelbeck and Neil Kirby), human factors (John Brebner), applied perceptual and cognitive psychology (Michael Lee and Douglas Vickers), decision making in applied situations (Michael Lee), 
consumer psychology (Paul Delfabbro) and environmental psychology (John Brebner). The structure of the program changed over time and now includes evidence-based practice (Deborah Turnbull), professional practice (Aspa Sarris), Human Resources (Aspa Sarris), organisational behaviour and management (Neil Kirby and Aspa Sarris), contemporary organisational psychology (Aspa Sarris and Neil Kirby), psychological assessment (Neil Kirby), and human factors (Anna Ma-Wyatt).

The inclusion of human factors as a course in the program was due to the available academic expertise of John Brebner, and this led to the naming of the program as the Master of Psychology (Organisational and Human Factors). Although there were some subsequent accreditation concerns about whether human factors should be included, it has remained a unique part of the program compared with similar courses locally and interstate. In the third year of the program, a further development in human factors involved students being able to complete placements and research projects at the Defence, Science and Technology Organisation [DSTO] in Adelaide. These placements and research projects were supported by scholarships from DSTO for the second year of the program. As a result of this arrangement, a number of students from the course obtained employment at DSTO and they now provide some of the supervision of subsequent student placements supported by these scholarships. Graduates who have had DSTO (now DST-Group) scholarships have also obtained positions in other government and commercial organisation using their expertise in human factors. This would have been a source of considerable satisfaction to Professor Alan Welford, a previous head of the Department of Psychology, whose work on information processing was closely aligned to human factors.

During the time the Master of Psychology (Organisational and Human Factors) has been operating, there have been significant changes in employment, including generally more part-time, contract and casual work. These changes are designed supposedly to make organisations more agile and able to respond to the challenges of changes in society, many of which have been driven by globalisation. Evidence on the effect of these changes in employment within universities was presented in a research paper by Millear and Nugent at the APS $11^{\text {th }}$ Industrial and Organisational Psychology Conference in 2015. Comments from a sample of academics employed on a casual basis in the eastern states of Australia included concerns about their future employment and the lack of a sense of belonging with respect to their colleagues. There are clearly problems here for organisational psychologists in motivating staff employed under casual and contract conditions and in retaining such staff, who are also becoming increasingly 'agile' in the sense of being less committed to particular organisations and more willing to move from one organisation to another if it benefits their careers.

Globalisation has also been evident in universities trying to achieve higher rankings in terms of other universities worldwide. An example of this with respect 
to a master's degree in organisational psychology was a relatively recent decision by one university to discontinue the program because it had apparently decided that departments should be centres of excellence in one particular area of the discipline. Accordingly, other areas, in this case including organisational psychology, were to be discontinued, to the detriment of vocational options for the university's students and to the detriment of psychology's contribution to the improved functioning of organisations in the community.

Evidence for psychology's much needed contribution to the improved functioning of organisations in Australia, particularly with respect to the role of managers, was provided by the Karpin Report in 1995, entitled Enterprising nation: Renewing Australia's managers to meet the challenge of the Asia-Pacific Century. In this report the poor person-related skills of Australian managers were highlighted. This report led to the establishment of a tertiary Graduate Certificate of Management/Graduate Diploma of Business Administration for managers offered by the Consortium of Australian Management and Business Schools [CAMBS]. This consortium included the University of Adelaide, and my involvement in the CAMBS course from 1997 to 2001 provided important teaching experience for the subsequent Master of Psychology (Organisational and Human Factors). A follow-up to the Karpin report by Sampson (2011) concluded that many of the recommendations of the first report had been acted on, although more by business organisations than government, mainly in response to market forces. However, the need for a continuing contribution from organisational psychology was indicated by three of this latter report's nine recommendations relating to the need to improve leadership, management education and people management.

The Master of Psychology (Organisational and Human Factors) has been successful insofar as it has attracted more than sufficient numbers of highly qualified students to fill the quota of ten students each year. However, a significant question, as for the graduates of the previous diploma program and the other master's programs, is whether the graduates from the course have had successful careers in organisational psychology and/ or human factors. A recent survey by Chodkiewicz (2016) provided positive answers to this question insofar as approximately 90 per cent of graduate respondents from 2004 (when the program began) to 2015 were employed in jobs involving organisational, human factors or related areas of work. Of the respondents, 92 per cent rated their job satisfaction as 'moderately satisfied' or 'very satisfied', using a five-point scale (very dissatisfied, moderately dissatisfied, neutral, moderately satisfied, very satisfied). In terms of work outcomes, 86 per cent gave positive ratings (moderate, good or great) for the extent to which they felt they had been able to improve organisational performance in their current role, and 79 per cent gave the same positive ratings for the extent to which they felt they had been able to improve employee job satisfaction (in both cases using a five-point rating scale — no improvement, minimal, moderate, good, great). 
There is informal evidence of the success of some of these graduates, who have returned to contribute to the program. For example, Stephen Kohl, who is the managing director of Genesys Australia, provides instruction and accreditation free of charge to students in the program on the range of Genesys computerised psychological tests. Kohl also serves on the program's advisory committee. Other graduate members of that committee include Hayley Lokam, who now has her own consulting company, and Agata McCormac and Kathryn Parsons, both of whom have senior positions at Defence, Science and Technology Group in Adelaide.

\section{Master of Psychology (Health)}

Another master's program introduced in 2008, while Deborah Turnbull was head of school, was a Master of Psychology (Health). This program became possible due to recent appointments of additional staff with expertise relevant to health psychology; the fact that some of the courses could be taught in common with the clinical master's program; and the interest of students, many of whom could not obtain places in the clinical master's program. The appointment in the School of Psychology in 2003 of Helen Winefield, a former graduate of the Department of Psychology who came from the Department of Psychiatry, and the appointment in 2005 of Deborah Turnbull, who came from the Department of General Practice, provided teaching expertise relevant to a Master of Psychology (Health) as well as to the clinical master's. Although the health master's degree shared courses with the clinical master's, it differed in its focus in being more concerned with community health issues and programs designed to improve public health, rather than with dealing with individual mental health problems.

Courses in common with the clinical master's programs included applied methodology, preparation for psychological practice, adult clinical psychology, psychological assessment, child clinical psychology, clinical geropsychology, health psychology, and rehabilitation and disability. Courses exclusive to the health master's course (with their associated course co-ordinators) included introduction to epidemiology (Peng Bi), and public health interventions (Christian Gericke), these latter two courses being taught by guest lecturers from outside of the School of Psychology.

Current courses taught in the health master's program and associated course co-ordinators include evidence-based practice (Deborah Turnbull), interviewing and intervention (Michael Proeve), psychological assessment (Helen Winefield), abnormal psychology (Linley Denson), introduction to epidemiology (Peng Bi) and health policy and public health interventions (Teressa Burgess). The health master's program has taken fewer students than the other two master's programs because of the limited available psychologists in the community for placement supervision. Also, like other master's programs, the growing standards required for such supervisors make it increasingly difficult to provide courses of this kind. 


\section{Master of Psychology (Defence)}

A fourth master's program developed in an arrangement with the Department of Defence in 2010 provided more specialised training for psychology graduates working in that organisation who had become registered as psychologists by pathways other than a master's degree. The program basically followed the same format as the clinical master's degree but it was discontinued in 2012 after a total of thirteen students had been enrolled, due to funding restrictions in the Department of Defence.

\section{The development of the psychological test library}

Although there had been a test library in the Department of Psychology at the University of Adelaide before the advent of the diploma course, it had relatively few tests. The needs of students in the diploma program and in the subsequent master's programs for training and practice in class and in placements required a much greater investment in tests, particularly in major tests such as the Wechsler scales of intelligence.

The original Wechsler Adult Intelligence Scale was published as the Wechsler Bellevue (after the hospital in New York where Wechsler worked) and there have now been four progressively updated revisions. These revisions have included more comprehensive norms, particularly for older adults, revisions to test items that had become out of date, the addition of new tests and new subscales, and revised theoretical formulation in accord with current hierarchical multifactorial models for intelligence.

Other Wechsler scales were added to the WAIS, including most notably modifications to the scale to make it suitable for children, thus challenging and eventually overtaking the Stanford-Binet's dominance in the assessment of children's intelligence. These tests were all expensive, which was understandable given the extensive research and testing that had to be completed in order to make their norms as representative as possible of the US population at the time. As administrator of the test library shortly after the beginning of the diploma course, I was associated with the acquisition of many more tests for both teaching and research purposes. I was assisted in this work for many of those years by Carmen Rayner, who was responsible for acquiring new tests requested by staff and students, for cataloguing the tests, for lending them out to students and staff, and for conducting an annual stocktake. In 2001, after many additions to the test catalogue, Rayner developed a computerised and online version of the catalogue to make it easier to search for tests. Wanda Prokopiak took over the day-to-day administration of the test library in 2007 and was responsible for acquiring many more tests requested by staff and students. Recently, Kate Chadwick from the centralised professional staff in the Faculty of Health Sciences has taken over responsibility for administering the test library, which now contains over 2000 tests, with an estimated value of more than half a million dollars. The test library has been, 
and continues to be, an essential resource for teaching applied psychology and for research in theoretical and applied psychology by staff and students.

The most recent editions to the test library have been computerised scoring and report-writing programs that provide time-saving assistance to test administrators but also dangers associated with the need to edit carefully the computerised reports. As expected, the report writers for tests like the Wechsler scales make it clear that the responsibility for the report lies entirely with the psychologist who signs it. The importance of intensive training in learning how to administer intelligence tests correctly, score them and write reports based on them has been revealed over the years of teaching in the diploma program and in the subsequent master's programs that replaced it.

An obvious failure of such training was demonstrated by an alarming example from a registered psychologist who attended a course that Ted Nettelbeck and I conducted for psychologists in the community who wanted to learn about a new edition of the Wechsler Intelligence Scale for Children. As part of this course, Ted Nettelbeck asked the participants to present any examples they had from their own use of the previous edition of the test which could be discussed in terms of limitations that the new edition would hopefully overcome. One particular participant brought in a test report that she had found puzzling because it indicated a borderline level of intellectual disability for a student who had been tested as part of an assessment of difficulties he was having at school. The results surprised the teacher and alarmed the parents, neither of whom had thought there was any issue with the child's level of ability. Once the test results had been examined, it was found that the early items on the subtests, which are supposed to be credited as correct if it proves unnecessary to go back to those items from the starting items, had not been credited. This had resulted in a much lower IQ than was in fact the case, and accounted entirely for the apparent discrepancy between the original test results and the teacher and parent evaluations of the child's intellectual ability. What was most alarming about this particular example was that the participant, after realising her mistake, commented that that was how she had always scored the test!

A similar example from a student in the diploma program occurred when students were required, as part of an assignment, to score a video of a young girl being given the Stanford-Binet. One student made a similar mistake in not crediting the first items that need to be credited if it was not necessary to give them, and duly handed up a report indicating a low-average IQ, when it would have been obvious to anyone watching the video that the young girl was highly intelligent.

Attempts to emphasise the importance of adhering strictly to the instructions and careful scoring were not always sufficient to ensure satisfactory performance in giving the test. In the earlier editions of the WAIS, it was left to the person giving the test to make up an appropriate way of introducing it, based on suggestions in the test manual. 
One student who was giving the test in a disability organisation under my supervision had clearly forgotten to do this, and, after laying out the test materials and the manual, suddenly found himself at a loss as to how to introduce the test to the person sitting opposite. After hesitating for a few moments he blurted out: 'Well, I'm going to give you some questions, and you're going to give me some answers!' I hastened to correct any impression the examinee might be having that this was some kind of interrogation by explaining as calmly as I could the purpose of the testing session. I also found that it was important to check students' pronunciation of certain words before administering the test. One student who was giving the information subtest of the WAIS under my supervision asked, 'Who wrote Foost?' instead of 'Who wrote Faust?'

In the subsequent master's programs, the introduction of a computerised report writer for the Wechsler scales posed new problems for teaching. This included the need to emphasise care when editing the computerised report to ensure that it was accurate with respect to the person and their circumstances. In a similar assignment to the one using the Stanford-Binet, students were asked to score a video of a WAIS being administered to a middle-aged woman who had a mild intellectual disability but no other disabilities. The students were advised in the background information that the woman being tested had been working successfully for many years at Bedford Industries. The computerised report writer usefully provides a list of possible recommendations that can be included in a report. However, in spite of being informed about the need to select appropriate recommendations, some reports included the entire list of possible recommendations, including in one report recommendations that was provided concerning the woman's psychiatric condition (which had obviously been cut and pasted from another report left on the computer containing the report-writer program) when there had been no indication in the background information provided that she had any such condition.

That students were not the only problem with respect to the use of the WAIS report writer was shown by the fact that the current WAIS report writer did not seem to have been tested by its developers on someone who had uniformly low scores across all the subtests. In describing the intelligence scores of another adult working successfully at Bedford Industries, the report writer referred to that person's abilities seven times as 'extremely low' in consecutive sentences, implying a much more limited coping capacity than was apparent in the video of the person being tested, who was able to converse with the test administrator in a way that was not much below normal limits and who had demonstrated his capacity to work successfully in sheltered employment.

The future of psychological testing will increasingly involve not only computerised reports but also online testing, which will eliminate the need to check that tests have been scored correctly. However, there will still be the need to ensure that the reports are accurate with respect to the person who has been tested and their circumstances. 
Online testing is also likely to mean that such teaching will need to be carried out by agents from the company that has developed and marketed the test and that requires accreditation for its use. This already occurs in post-registration training in which psychologists have to pay for the training and accreditation required to use the tests. However, some of this kind of training also occurs in the current Master of Psychology (Organisational and Human Factors), to the benefit of the students who do not have to pay the relatively high cost of the training. The advantage to the test developers is that students are more likely as a result of that training to use their tests.

The increasing cost of some psychological tests has also made it difficult for students to conduct research that involves the use of such tests. This may become even more of a problem with online tests that not only are expensive but also require students to have accredited training to use the tests, even for research purposes. This may affect the extent to which commercial psychological tests can be appropriately evaluated because the companies themselves may have limited incentive to research the reliability and validity of tests that already have 'financial validity' in terms of successful sales.

Commercialisation of instruction and accreditation has also occurred in specific therapy and intervention workshops available to registered psychologists who work, or intend to work, in specialised areas such as the treatment of trauma from neglect and/or abuse in children. These workshops can require weeks of costly training plus supervision, and additional costs and training to become a supervisor of other psychologists who complete the workshops. To the extent that such training programs produce knowledge and skills required for certain types of psychological practice, this could affect the future teaching of applied psychology in universities. While they have not been used as yet in the clinical or health master's programs, they might in the future follow psychological testing workshops in being made available to students as part of their coursework.

If in the longer term such commercialised teaching courses were to become available in undergraduate teaching, it might have major implications for the role of lecturers, their work being progressively taken over by online teaching that only needs local tutors to support student learning.

\section{The Bedford Industries research fellowship and research in applied psychology}

The Bedford research fellowship was of direct assistance to students of the Applied Diploma in Psychology in terms of teaching content, research projects, student visits to the centre and subsequently for employment of students as rehabilitation officers. Research projects at Bedford Industries included not only those associated with diploma student theses but also honours and PhD theses and subsequently master's degrees. 
Many of these research projects were carried out within the experimental psychology tradition in which Ted Nettelbeck and I had been trained.

The information processing model of human behaviour which guided much of the teaching and research in the Department of Psychology during the 1970s owed much to the influence of Alan Welford, head of department from 1969 to 1975. He had previously written a book that took an information processing approach to ageing (Ageing and human skills, 1958) and, while head of department, he completed another book called Fundamentals of skill (1968), which became an influential textbook guiding much of the information processing research carried out by $\mathrm{PhD}$, diploma, honours and master's students under the supervision of staff including Ted Nettelbeck, Douglas Vickers, Donald McNicol, John Brebner and myself. The information processing approach was used to study perceptual, memory and motor performance across the lifespan from childhood to old age, including the slower and more variable performance of people with an intellectual disability.

One of these information processing studies had an unexpected rehabilitation outcome. In this study, scores from adult intelligence tests used to assess eligibility for Bedford Industries were checked to ensure that participants were in the appropriate range of intellectual disability required for publication of the research. The scores revealed a number of workers in the food packing room within the required moderate IQ range, but one particular worker who did not have an IQ score and needed to be tested was found to have an IQ in the 120s. Investigation of this anomaly revealed that the person in question had been at university but had suffered a mental breakdown, and had been sent to a psychiatric hospital and from there to Bedford Industries, where he had completed his rehabilitation. However, he confessed that he had found working in the food packing room quite congenial and had continued to go on working there, given that no-one seemed concerned about it. On being advised that having completed his rehabilitation, he should now return to the university to complete his degree, he did so.

Practical applications of psychology at Bedford Industries which involved research students included the setting-up of training vestibules in the furniture assembly area and in the industrial sewing area. These six-week training programs taught work behaviours and basic work skills before new employees graduated to the production lines of these departments. Task analysis and the training techniques developed by Neil O'Connor in the UK and Marc Gold in the US were used to teach work skills, with considerable success. However, a problem for conducting and evaluating applied research theses on projects such as those involved with training was that, unlike experimental studies using rats or first-year students, it was often difficult to obtain representative samples and matched control groups, particularly amongst people with disabilities who, in spite of having the same diagnosis, could differ markedly in how the disability manifested itself because of other associated disabilities. This was demonstrated in Antonergias's (1983) 
thesis, which involved developing and evaluating a video-based training program in the woodwork training vestibule for how to lift correctly.

As the supervisor of this research project, I had asked the woodwork training officer to choose a number of clients working in furniture assembly with mild to moderate intellectual disabilities who would be suitable for the study. The nominated participants were duly assembled on the designated day, during which the student, with my assistance, was to make the training video as part of her research thesis. The format for the video was to show first how they would lift a heavy box without instructions and then how they would lift it correctly with accompanying voice-over instructions.

A relatively large empty cardboard box was used for the demonstrations so that it could be lifted easily without causing any problems. At the beginning of a videoed trial, the box was placed on a certain spot on the floor and while the student operated the video camera, I told the participant to pick up the box as they would normally, and carry it about six paces and then place it on another marked spot on the floor. The first participant was given these instructions and approached the box to pick it up but slipped and fell over the box. After we had checked that he was okay, he was asked to try again, which he did, but with the same result. I thought that perhaps there was oil on the floor, but he indicated that it was not the floor but his leg that was to blame. When we enquired about his leg, he informed us that he had a wooden leg, which made it very difficult for him to bend down. After revealing the wooden leg beneath his trousers, he was excused from taking any further part in the study.

The next participant was given the same instructions and he approached the box to pick it up but gave a sudden skip as he did so. Since this would be distracting on the video, he was asked to perform the task again but this time without the skip. He again attempted the task but at the last moment gave the same sudden skip before picking up the box. On asking the training supervisor why he might have done that, we were informed that he had an additional disability that involved sudden involuntary movements, particularly when he felt under pressure. He was also thanked for his participation and was excused from the study.

Before giving the instructions to the next participant, I checked with the training supervisor that he was suitable for the task, and, in particular, that he did not have a wooden leg or sudden involuntary movements. Once I had been assured that none of these issues applied, the third participant was given the instructions to lift the box and carry it to the designated spot. The third candidate approached the box and was about to pick it up when he paused and looked first at the box and then at me. I asked him if everything was okay, whereupon he asked what was in the box. I asked why he wanted to know that, and he said that how he picked it up would depend on how heavy it was. I informed him that in fact there was nothing in the box, whereupon he asked why, if that was so, he was being asked to lift it. I explained that it was an exercise in lifting 
and that he was to imagine that the box was quite heavy when he picked it up. Once he was satisfied on these issues, he was again given the instructions and his actions were videoed. He approached the box and bent down as if to pick it up, but then, instead of doing so, he pushed it across the floor to the designated spot, explaining as he did so that if the box was quite heavy as I had indicated, he would not pick it up but slide it.

At this point I could see that the student was obviously worried about how her research project was proceeding, so we had a break during which I asked the training supervisor why the third candidate had acted as he had. We were informed that he had an additional mental health condition that made him suspicious of other people's intentions. Fortunately for the student, the following participants were able to perform the lifting task as required and she went on to complete her research thesis satisfactorily.

\section{The research caravan}

To assist in the applied research carried out by staff and by diploma, honours, master's and $\mathrm{PhD}$ students, a specially equipped caravan was built and stationed at Bedford industries. From there it could be towed to schools and other organisations in the community, where it provided a room equipped to carry out experiments, particularly with respect to information processing tasks including reaction time and vigilance. It was at this time that the department acquired its first computer, which could be connected to lights and keys in order to obtain reaction time data. The computer was considered portable, although it was the size and weight of a small fridge and the program to collect data took approximately twenty minutes to load using perforated paper tape, which often broke, requiring another twenty minutes. This original computer was replaced by increasingly smaller and more powerful computers that could be programmed much more easily to provide more complex reaction time tasks including, in particular, the inspection time task used by Ted Nettelbeck in his studies of intellectual disability and changes in information processing capacity across the lifespan.

\section{Changes in the demographics of students in applied psychology}

A survey of organisational psychologists in Australia by Kirby and Hartstone (1998) showed a significant increase in the percentage of female organisational psychologists from 14.6 per cent in an earlier similar survey by Barkway and Kirby (1983) to 35.1 per cent, although this was still much less than the 67 per cent female membership of the Australian Psychological Society at that time. The survey also showed significant gender differences in job functions, with females being more involved in job functions like conflict management and communication effectiveness and males being more likely to be involved in job functions like psychological testing. In the research thesis on which this study was based (Hartstone, 1994), these 
differences were related to the way male and female psychologists think about therapy, with females tending to prefer relational thinking and men preferring instrumental thinking (Johnson \& Stone, 1989).

A similar increase in the percentage of females to that in the above study occurred during the years of the diploma program and the subsequent Master in Clinical Psychology and Master in Health Psychology which replaced it. I taught in all these programs since their inception, and was not particularly aware of this gradual change in gender balance until 1997 when, teaching in the clinical program, I was suddenly struck by the fact that I was the only male in the room. Going back to the photographs of students in each year and counting the numbers of males and females, I found that although there were marked variations from year to year the diploma program had approximately equal numbers of males and females during its first four years but the proportion of females had then increased until in 1987, its final year, 86 per cent of the students in the course were female. Figure 4.1 shows that this change in the proportion of females in the diploma program continued in the subsequent clinical master's program, reaching 100 per cent in 1997, and that a similar change occurred in the corresponding years of the honours program and in the health master's program. A lower overall proportion of females is evident in the organisational master's program, which began in 2002, although there are marked variations because of the relatively small number of students in the course each year. The overall increase in the proportion of females in these programs has also been evident in the profession generally and suggests that psychology may become a predominantly female course and profession.

Kimble (1984) published an article entitled 'Psychology's two cultures', in which he contrasted two very different attitudes to psychology amongst both academic and applied psychologists. He developed a measure consisting of twelve dimensions including, for example, beliefs about scientific versus humanistic values, determinism versus indeterminism in behaviour, objectivism versus intuitionism as a source of basic knowledge, laboratory versus field research, and cognition versus affect. Each alternative was accompanied by a description in favour of that alternative and participants were asked to rate their endorsement of each pair of alternatives on a ten-point scale, from fully endorsing one alternative to fully endorsing the other. Kimble used the sum of scores on these dimensions to contrast a more scientific approach with a more humanistic approach to psychology and found significant differences on this measure in the expected direction between different divisions of the American Psychological Association at that time. For example, members of the psychotherapy division were more humanistic in their approach than those in the experimental division. Kimble noted what he saw as a trend towards a coming-together of some but not all aspects of the two cultures.

Kimble did not report gender differences, but an undergraduate exercise that I conducted in 2006 as part of a history of psychology course, using Kimble's measure, 
showed a significant difference between male and female students, with the female students being more humanistic in orientation and the males more scientific. An implication of this finding, if it were replicated on larger samples after following formal research procedures, is that an increasing proportion of females in psychology may result in a shift to a more humanistic rather than scientific orientation in research and practice.

To test this predicted gender difference with respect to applied psychology, it would be interesting to follow up the subsequent careers of the more than 300 students from the diploma course. That this has not been done in what purports to be an evidence-based profession may be surprising, but this may be because before the diploma it was assumed that graduates from the existing $\mathrm{PhD}$ program would obtain academic positions, while those with a third-year or honours degree might obtain employment in many different kinds of jobs. This research could also be extended to graduates from the subsequent master's programs. Interestingly, in a recent survey of graduates from the organisational psychology program, Chodkiewicz (2016) found no obvious differences between the types of job functions of male and female graduates from that program.

It would also be interesting to determine the extent to which male and female graduates have moved into management positions in organisations that allow them to influence the policies and strategic planning of the organisations in which they are employed, particularly with respect to the use of applied psychology and applied psychologists. In the survey by Chodkiewicz, the percentage of organisational graduates in middle or higher levels of management increased from 15 per cent in their initial employment to 56 per cent at the time of the survey, with significantly more males having moved into middle or higher levels of management.

\section{Applied research in the Department (now School) of Psychology}

The establishment of the Bedford research fellowship in 1972 and the introduction of the Diploma in Applied Psychology in 1974 led to an increased focus on applied research not only in the diploma and subsequent master's programs but also in the $\mathrm{PhD}$ program. However, unlike the applied courses there was no marked increase in the proportion of females completing $\mathrm{PhDs}$ and no marked increase in the proportion of applied PhD topics until the year 2000. Figure 4.2 shows the total numbers of males and females in blocks of five years, from 1975 to 1979, 1980 to 1984 and so on until the present time. Also shown are the equivalent numbers of theoretical and applied PhDs as indicated by a rough classification that I made based on the title of each thesis. It is evident that there were generally similar numbers of male and female $\mathrm{PhD}$ students and theoretical and applied topics for their theses until the year 2000, after which a dramatic increase is apparent in the two five-year blocks since that time 
in both the number of female $\mathrm{PhD}$ students and the number of applied $\mathrm{PhD}$ theses. There was a similar increase in the percentage of female students undertaking applied research when opportunities for $\mathrm{PhD}$ research were facilitated by the Faculty of Health Sciences (to which the School of Psychology belonged), as the faculty wanted to increase the numbers of $\mathrm{PhDs}$ in order to improve access to available Commonwealth Government funds. This marked increase in research was achieved with only a modest increase in staff.

I do not intend to provide a detailed account of applied research in this chapter but it is interesting to note that the increase in applied PhDs was not only due to research on disability or on problems in the community such as gambling, unemployment and how patients deal with medical conditions. The demise during the late 1990s of the 'rats' part of the 'rats and stats' description of psychology involved the elimination of the first-year and second-year rat practicals that were used to investigate operant conditioning principles. This ended an experimental tradition within the department which had involved the use of monkeys and cats in studies of the corpus callosum in the 1960s by the first head of department, Malcom Jeeves, and work using rats during the 1970s and 1980s which was conducted by Peter Glow on the effects of drugs on the nervous system, and by Tony Winefield and Frank Dalziel on learning.

However, the end of teaching and research using rats did not entirely end animal behaviour as a teaching or research topic within the department. The laboratory work with animals was subsequently applied to animals in the Zoo, just as, during that time, other topics in psychology like intelligence, personality and learning were being applied in the community. Frank Dalziel, who had taught classical and operant conditioning and who had organised the first-year and second-year rat practicals, now began to supervise studies of animal behaviour at the Adelaide Zoo, and his students' studies were influential in designing environments involving novel stimuli for the animals to explore and puzzles to solve to obtain food, which created a more natural environment for the animals. This applied work in the department ceased with Frank Dalziel's death in 1999, but the legacy of that theoretical and applied work was continued elsewhere by a number of his postgraduate students.

Although the dramatic increase in $\mathrm{PhD}$ research that began in the late 1990s (as shown in Figure 4.2) was largely due to the aims of the Faculty of Health Sciences to markedly increase $\mathrm{PhD}$ research, the availability of necessary funding was partly a consequence of the continuing impact of the Dawkins reforms on higher education, which placed a much greater emphasis on university research.

\section{The Dawkins reforms}

The Dawkins reforms, first announced in Higher education: A policy discussion paper (the 'green paper'), which was published in 1987, and subsequently in Higher education: 
A policy statement (the 'white paper') in 1988 by the then Labor government, resulted in Colleges of Advanced Education [CAE], which had focused on vocational training, being changed into universities with a requirement to pursue research in addition to teaching, and existing universities having a greater emphasis on research output and more of a teaching focus on vocational training. The aim was to make the resulting university system more efficient and internationally competitive.

Criticisms and benefits of the Dawkins reforms are discussed in an article by Ashenden (2012), a former ministerial consultant to a federal minister of education and a founder of the Good Universities Guides. The criticisms have included that it was an attempt to reduce public funding and shift the cost of universities onto students (including overseas students from non-English-speaking backgrounds who paid full fees); it aimed to commercialise university education with consequent managerial constraints on teaching and research; it demonstrated an intensified 'publish or perish' attitude at the expense of teaching and community service; it involved the dumbing-down of the curriculum to accommodate a much larger number of students; and it resulted in the relative neglect of the state-based TAFE systems. Similar criticisms have been made in other publications (see, for example, Cain and Hewitt, 2004).

Those criticisms notwithstanding, my experience of overseas students has been very positive in terms of many of the students' motivation to study, their intellectual ability and their capacity for hard work. However, providing feedback on drafts of some theses by overseas students often meant additional work. Nevertheless, the input from overseas students in the Master of Psychology (Organisational and Human Factors) program, in particular, has been highly beneficial to that course in terms of providing a more international perspective on organisations and working conditions, and some overseas students in the program have completed placements in Hong Kong and Shanghai.

As indicated by Ashenden in the above article, advocates of the benefits of the Dawkins reforms argued that it made Australian universities more competitive internationally in terms of teaching and research, and the way in which students could delay payment of university fees until they were employed meant that a university education became available for many more students. Advocates further argued that the existing university and CAE systems were woefully inefficient in teaching, research and administration, and that academics abused what was essentially a position of wealth and luxury. Certainly, there were instances of abuse, as there are in every profession, but I only ever attended one of many informative seminars given by staff returning from their study leave which consisted of little else but travel slides. However, a rumour at that time, that a full-time CAE academic had organised all of his teaching into one day so that he could spend the other four days working on his farm, certainly did not help this perception of academics. 
Prior to these reforms, the university academic was expected to know what was known and not known about a particular topic within a university discipline, and to conduct research into how more could be known about the topic. After these reforms, what was taught in universities was increasingly influenced by what employers of graduates wanted them to know, and what was researched was increasingly determined by what the government was prepared to fund. I for one have a considerable feeling of nostalgia for the inspiration provided by teachers and research supervisors who were enthusiastically interested in their teaching and research topics, rather than, in some cases, in what they had to do to obtain promotion or, increasingly, to have their employment contract renewed or their casual employment continued.

With respect to promotion, the reforms resulted in the neglect of teaching and service to the community in the pursuit of research projects that the academic might be more or less interested in. As indicated in the article by Ashenden, the reforms also resulted in the obligation to quantify the quality of research through setting objectives to be achieved in terms of the size of grants and the numbers of publications in 'high impact' journals and citations. I remember attending a committee meeting discussing the research-funding objective that had been set for the faculty. At the meeting, one member of the committee mentioned a grant of tens of thousands of dollars, only to be dismissed impatiently by another member of the committee, who said, 'That's no use; we need grants worth hundreds of thousands'. Certainly, these reforms posed increasing funding problems for university administrations, and these problems have continued to the present time.

The criticism that, as a result of the Dawkins reforms, universities were increasingly required to teach a vocational curriculum determined more by the employers of their graduates than by the requirements of the academic curriculum can be countered by the observation that some university courses related to the professions had always been involved in vocational teaching. It is certainly the case that vocational training in the School of Psychology at the University of Adelaide began a decade and a half before the Dawkins reforms. Nevertheless, the dramatic increase in the number of its $\mathrm{PhD}$ graduates is consistent with the increased emphasis on, and funding for, research that followed the Dawkins reforms.

\section{The future of applied psychology research for teaching}

An important issue concerning the application of psychology in society was raised in a seminar given in the Department of Psychology by Jeffery Richards, who was appointed to the department in 1997. The issue concerned the effective implementation of applied psychology. As I remember, he argued that psychology did not need any more theories of behaviour; what it needed was research in how to apply its knowledge effectively - 
for example, how to develop effective teams to deliver services and how to ensure that what is learnt in training is transferred as intended to the workplace.

Having attempted to apply psychology at Bedford Industries over many years and having observed attempts to apply psychology in other government and non-government service organisations, I was certainly in agreement with his argument. As already indicated in the section concerning the Master in Organisational Psychology, I had begun to consider that the particular branch of psychology that was most relevant to effectively applying psychological knowledge in community settings was organisational psychology. In my work with rehabilitation officers at Bedford Industries, I came to believe that many of the problems they encountered in applying their psychological knowledge were due to a lack of knowledge about how organisations function. As a result, I became interested in learning about and teaching organisational psychology, and this led to my introducing courses on the topic into the curriculum of the Department of Psychology. Ultimately, it assisted in the development of the master's program in organisational psychology.

The need for more teaching about change in organisations has been discussed in reviews of the role of organisational psychologists in Australia by Barkway and Kirby (1983) and Kirby and Hartstone (1998). In the masters thesis on which the latter article was based, a participating organisational psychologist commented: 'Not much in your list of functions covering facilitating organisational change as a result of downsizing/retrenching/merger/acquisition and so on — which is the reality in organisations, but not so apparent when viewed from an academic "classificatory" perspective' (Hartstone, 1994, p. 68). Comments were also made in both these reviews on the need for organisational psychologists to promote the services that the profession could successfully apply to organisations.

Subsequent work in trying to apply psychology has led me to believe that there was also a need for research into how to ensure that successfully implemented changes are maintained over time. The research literature supports this need for research into how and why implemented change programs fail to be maintained. Meta studies have shown that between 28 per cent and 93 per cent, with an average of 3 per cent, of implemented programs in organisations fail (Decker, Durand, Mayfield, McCormack, Skinner, \& Perdue, 2012, p. 29). Surprisingly little seems to be known about the critical factors that facilitate or inhibit the maintenance of organisational change, and little is also known about the time scale within which these failures occur. Given the costs associated with implementing many organisational change programs, a failure rate of this kind provides a financial imperative to investigate such poor cost-benefit results. How to facilitate the maintenance over time of successfully implemented change programs would be a very valuable skill for applied psychology students to be taught. 
A particularly telling example related to me in conversation can be used to illustrate how successful change can fail to be maintained. At a conference on disability in Adelaide in the 1990s, I was told by one of the delegates about his previous experience of working at an institution for adults with severe intellectual and other disabilities, where he had been involved in a behavioural training program designed to teach dressing and toileting skills to clients using techniques based on operant conditioning principles. After many months, he and his co-workers had succeeded in teaching some of these skills, in particular the ability of the clients he was working with to dress themselves.

He had subsequently left that organisation and gone to work in another disability organisation for a number of years, after which he moved to a third disability organisation. While waiting to start this new job, he decided to return as a volunteer to the organisation where he had been involved in the training program. To his surprise, he was assigned to the same villa with the same clients whom he had previously trained. Even more surprising was the first instruction he received from the supervisor, which was to dress the clients. His claim that they could dress themselves was dismissed by the supervisor, who said that they were much too disabled to do that. To prove that they could dress themselves, he laid out their clothes as he had done when he had trained them and instructed them to dress themselves. To the astonishment of the supervisor, the clients did so. When asked how he could have possibly known they could do that, he said it was because he had trained them to several years ago.

This is a very good example of how psychology can be applied effectively but only in the short term. An interesting research project at that time would have involved finding out how those clients ended up being dressed again by the staff. My own speculation is that time may have been a critical factor. A busy schedule that involved getting clients ready for an outing or staff having a number of duties to be completed within a particular time, or an unwillingness to allow (or to waste) time while clients slowly dressed themselves, could have led to speeding up the process by helping the clients to dress themselves, and eventually dressing them completely. It would only take a change of staff for the previous knowledge that they could dress themselves to be lost and, accordingly, for it to be assumed thereafter that they needed to be dressed.

The failure of successfully implemented change programs to be maintained can also apply more broadly to successful approaches to, and policies concerning, particular issues in the application of psychology. As part of the consultancy to Bedford Industries, the research fellowship developed a client induction manual as well as assessment, placement and training guidelines for rehabilitation officers and training programs to be given by the rehabilitation officers to supervisory staff. Training manuals were written for these programs, which provided instructions and practical exercises for supervisors on how to supervise their employees with disabilities, how to use behaviour management techniques appropriately to improve work and social behaviours, and 
how to use task analysis and training techniques based on operant conditioning and information processing theories to facilitate the acquisition of work skills.

These training techniques led to much greater acquisition of work skills than had been previously achieved with the commonly used 'show and tell' or 'sitting by Nellie' techniques that were used by supervisors who had had no such training. Procedural manuals were also written for the furniture assembly section, the industrial sewing section and the metalwork section of Bedford Industries. All of these developments were used to inform my teaching in applied psychology at the undergraduate and postgraduate levels. I had assumed in my teaching at the time that such successfully implemented training techniques would continue to be developed and implemented, but this did not happen. The relevant research literature showed a decline in research on the development and application of training techniques after the 1980s in favour of more research on disability rights and advocacy (Hampel, 2007).

I was personally made aware of this decline in interest in training techniques, in relation to Marc Gold's Try another way system for training people with severe intellectual disabilities. Gold had developed this task-analysis-based system with associated videos and had published it in his Try another way training manual (1980a); he had commented further on it in his book Did I say that? (1980b). To assess the learning skills of people with severe intellectual disabilities as a basis for using training techniques of this kind, Irvin, Gersten, Taylor, Close and Bellamy (1981) had published a revised version of a test called 'The Trainee Performance Sample'. When a master's student wanted to use this test for her research thesis, it was found to be missing from our test library, so I contacted the publishers, only to be told that it was out of print. I then contacted the senior author, Larry Irvin, who wrote back saying that unfortunately he did not have a copy that he could send us. He also commented that he was retiring and that looking back he lamented the fact that there now seemed to be so little interest in applying these training techniques. He further commented on the pleasure that he still derived from seeing people with intellectual disabilities in open employment for which he had been involved in training them. Partly prompted by this apparent decline in research and application of training techniques, a $\mathrm{PhD}$ in Education at the Flinders University of South Australia (for which I am an external advisor) is now investigating the extent to which these training techniques are currently being used by supervisors in disability organisations. Preliminary results suggest anecdotally that many of the task-analysis-based training techniques pioneered by Marc Gold and others are not being used and that much training has reverted to 'show and tell' and 'sitting by Nellie'.

That organisational change can also mean the reduction or elimination of successful programs is illustrated by an initiative associated with the Bedford Research Fellowship for people with disabilities to attend TAFE colleges in order to learn work skills in simplified apprenticeship courses. These courses, which were arranged 
to teach woodwork and metalwork skills at Marleston and Panorama TAFE colleges respectively, were also very successful in developing the participants' self-esteem. The courses were taken on by teachers at these colleges who had no training in teaching people with disabilities but who volunteered to do so because they found the idea challenging and exciting. There were initial concerns that such training would not be successful; indeed, I remember waiting anxiously with several Bedford rehabilitation staff for a phone call to say that the training was not working. But no such call came, and when the woodwork trainer, in particular, was asked how the Bedford workers had behaved themselves, he answered that he wished his first-year apprentices were as eager to learn as they were.

On the basis of the success of these courses, I argued in a published article (Kirby, 1985) and as part of a Commonwealth Government review of disability services that resulted in the Disability Services Act 1986 (Cth) that the TAFE system was ideally placed to provide the tertiary education appropriate for young people with developmental disabilities who took longer to acquire work and independent living skills than their nondisabled peers and who therefore needed, and would benefit from, the additional time in education which TAFE could provide. This recommendation was consistent with new service guidelines in the Disability Services Act 1986 (Cth), which included the use of generic services, including education. Changes in disability service guidelines of this kind were incorporated into my teaching of disability service concepts in undergraduate and postgraduate courses. The TAFE programs associated with Bedford Industries were eventually extended into horticulture, with many workers in the garden maintenance department along with those completing other similar courses receiving certificates at annual ceremonies. These programs continued for many years during and after the ending of the Bedford research fellowship until approximately five years ago, when they were unfortunately discontinued due to restructuring in TAFE.

That worthwhile applied psychology changes in organisations may come and go and come again was illustrated in a seminar to a master's class on mental health services some years ago by a psychologist who had had extensive experience over many years in these services. When asked by students to comment on how these services had changed over time, he drew a circle on the whiteboard and proceeded to explain how these services in his opinion had improved and declined and improved and declined with changes in government, changes in the economy, and with new and sometimes misguided enthusiasms about how to run such services. Such changes, he said, all variously involved new approaches to treatment, amalgamations and renaming of services, decentralisation of services, employment of more psychologists, downsizing and changes in the roles of staff, greater resources, and reductions in resources. He then commented on the stage of this circle at which he believed services were at the time of his seminar. 


\section{The future of teaching applied psychology}

At the time of writing, topics in undergraduate teaching in the School of Psychology at the University of Adelaide continue to be more theoretical than practical in their approach. These topics include research methods; perception and cognition; health and lifespan; psychology in society; individual differences in personality and assessment; learning and behaviour; mind, brain and behaviour; and organisational psychology. There are three master's programs: Clinical; Health; and Organisational/Human Factors.

All such master's programs currently face challenges, as discussed in a Psychology Board of Australia green paper (2015), particularly with respect to providing student placements. This is because of the increasing standards for placement supervisors, which include registration, supervisor training and endorsement. These requirements, which must be in place by 2018 , will make it difficult for some master's programs to continue, and it has been suggested that some may be forced to close. An organisational psychology alumni survey by UQ Centre for Organisational Psychology at the University of Queensland in 2015 conducted a survey to assess the appeal of a program in business psychology which would avoid these requirements by not leading to registration. A further problem created by the need for supervised placements as part of the master's programs is that their limited availability means that enrolments in these programs must likewise be limited, thus making them expensive to operate.

Although placements for students are becoming increasing difficult to arrange, they have been a very important part of the applied training in the master's programs. Their advantages include providing not only practical training in three different work situations within a master's course but also opportunities for students to choose, from a number of different placement options, those options of most interest to them in terms of their future careers. Having three different placements also allows them to try out job options that they may not have considered previously. A potential benefit to placement organisations is that the placement provides them with the opportunity to consider a student on placement with them as a potential employee, should a position become available. Evidence suggests that many students find their first employment through one of their placements (Carless, Cuozin-Wood, Duncan, Imber, Munro, \& Novatsis, 2003). Chodkiewicz (2016) found that graduate respondents from the Master of Psychology (Organisational and Human Factors) rated placements higher than coursework or their research thesis in preparing them for their careers, and that 46 per cent had obtained their first employment as a result of a placement. In fact, there have been a number of students who have received job offers from their placement organisations before finishing the program. There have also been examples of students who tried out a placement in human factors work at DST Group and found that they 
liked the work so much that they subsequently found employment in jobs requiring knowledge and skills in human factors.

The master's programs have been dependent on the goodwill of placement supervisors who receive no monetary compensation for the considerable amount of supervision that they provide to students each year. As recognition of this essential contribution to these programs, the School of Psychology in 2013 offered the position of adjunct lecturer to all psychologists in the community who contributed to one or more of the courses, as a placement supervisor and/or as a guest lecturer providing seminars. Adjunct lecturers can use this title officially, and it entitles them to use the resources of the test library in the School of Psychology and gives them access to the resources, including the electronic resources, of the university library.

A green paper published by the Psychology Board of Australia (2015), mentioned earlier, discusses critical issues facing the training of professional psychologists (including the relevant evidence for these issues). The green paper includes discussion from representatives of the Psychology Board of Australia [PsyBA], the Australian Psychology Accreditation Council [APAC], the Australian Psychological Society [APS] and the Heads of Departments and Schools of Psychology Association [HODSPA]. A particularly important issue concerns trying to ensure that appropriately high standards are met for the different ways in which students can obtain registration, particularly the standards for the supervision of work for registration after completing an honours degree or an honours degree followed by a one-year graduate diploma.

Other critical issues include the restricted number of places available in master's programs because of constraints on appropriately qualified placement supervisors; the possibility that organisations generally will begin to charge for placements, thus making these programs more expensive; and the diminishing number of non-clinical master's programs, which results in reducing the range of careers in applied psychology. Consequences of the restricted number of places include a bottleneck at the fourth-year level in psychology, with many students unable to access these programs, and the difficulty in meeting the demand for psychologists now and in the future. A more general issue of apparent concern to the government is the amount of study required for registration and whether this could be reduced, for example, by eliminating the honours degree. Reducing undergraduate training in theoretical psychology, if adopted, would begin to undermine Lightner Witmer's (1907) insistence on a sound theoretical basis in psychology before learning to apply it and would, as I pointed out when discussing this issue earlier in this chapter, reduce the scientist part of the present scientist-practitioner model.

Options considered as ways of dealing with these issues include introducing a European style master's program that would involve a three-year bachelor's degree followed by a two-year master's degree and a one-year internship. An alternative 
option is having a generic master's program that does not require placements, with specialisation in a particular area of applied psychology occurring in supervised employment subsequent to completing the master's program. These options without the constraining effect of placements are seen as ways of increasing the number of places available in master's programs, making them more economical to administer for universities whilst simultaneously dealing with the demand for more psychologists. Arguments have been considered in the green paper both for and against these and other options, with the only apparent consensus being the desirability of phasing out the present 'four plus two' option (four years of study including an honours year followed by two years of supervised employment in the community) and the need for a simpler pathway to ensure a well-trained workforce of psychologists.

The adoption of a generic master's degree would be a case of 'back to the future', with a two-year version of the original one-year diploma program but without the placements. However, in arguing against the existing master's programs, Lyn Littlefield claims (Psychology Board of Australia, 2015, p. 12) that '[f]or a number of reasons most likely related to the current funding arrangements for psychologists under Medicare, the area of greatest demand is for Masters courses in Clinical Psychology'. Littlefield further argues that

market forces have already changed the landscape for Masters-level professional programs by creating a homogenising of education and training content around clinical psychology, to the detriment of other areas of practice; the 'standard' Masters professional training is becoming basically a program in clinical psychology. (p. 12)

Given such existing demand, a generic master's program might also end up concentrating on clinical practice at the expense of other areas of applied psychology, thus reducing the contribution that different types of applied psychology could make to society.

The green paper makes it clear that there are many complex issues associated with developing new approaches to the training of applied psychologists. However, at the present time the increasing standards for supervision threaten to markedly restrict the range of applied psychology programs, particularly non-clinical programs, and the numbers able to be trained as clinical psychologists. Perhaps there is a need to question whether it is worth trying to increase standards for supervision if the long-term results are that markedly fewer applied psychologists are working in a very restricted range of clinical psychology jobs. Other professions with perhaps less relevant knowledge and skills will doubtless take over the remaining types of work. Options for supervision standards that would overcome these problems include leaving them as they are, given that the need for higher standards might no longer be necessary if the four-plus-two option and also the five-plus-one were to be discontinued, and/or having less restrictive supervision standards for non-clinical programs than for clinical programs. 
There is also a need to consider some kind of work qualification for the many third-year graduate students in psychology who cannot access honours or master's programs. Perhaps there is a need to revive a version of the original diploma program in psychology (without placements) as a fourth-year alternative to an honours program which would not lead on to registration. Such a program could provide basic knowledge and skills in applied psychology useful in a wide variety of jobs dealing with different aspects of life including infancy, childhood, education, work, family, leisure and old age. It would need to provide skills that would put its graduates at an advantage for such jobs - for example, not only basic interviewing and counselling skills, but also skills concerning program design and evaluation, individual and group training, working in organisations, and report writing. Skills associated with working in organisations would facilitate entry into management, where graduates could influence the effective use of applied psychology. The possibility of this kind of qualification has been considered by a committee in the School of Psychology with Anna Chur-Hansen as head of school, but the current need for such a course to be full-fee-paying does not make it a viable option.

A more general problem for the future diversity of applied psychology is achieving a secondary school curriculum in psychology which emphasises the different vocational options within the field of psychology. The present textbooks in the South Australian secondary school system provide a general introduction to theoretical psychology with an applied focus that is mainly on clinical and health psychology, with only a paragraph-long description of other major areas of applied psychology. Such alternative vocational options could be easily overlooked by teachers and might account for the number of undergraduate students who at interviews for the organisational master's program say that they had never heard of organisational psychology (or any other form of psychology apart from clinical) until encountering it in an undergraduate psychology course. A secondary school psychology textbook that devotes separate chapters to the different vocational options in applied psychology would attract a wider variety of students interested in one of the alternative careers to clinical psychology.

It is also likely that more of these students would be retained in undergraduate psychology if there was a range of master's programs in areas such as clinical, health and organisational psychology with their economies of scale, plus a fourth-year diploma in applied psychology that would not lead to registration but would be available to all those third-year graduates who are unable to enter the honours program.

A more general but also important consequence of a secondary school psychology program that represents the diversity of applied psychology would be to educate the public about the variety of ways in which psychology can contribute positively to society. 


\section{Summary comments}

Over the forty-one years that applied psychology has been taught in the School of Psychology at the University of Adelaide, there has been growth from one diploma program to the present three master's programs in clinical, health and organisational/ human factors, offering students a range of vocational options in applied psychology. These programs were organised and taught for many years with very limited additional resources for staff members, most of whom were experimental psychologists with little or no practical experience in applying psychology. The total students enrolled in these programs since they began include 331 students enrolled in the diploma program, 377 in the clinical master's, 13 in the Clinical Master of Psychology (Defence), 47 in the health master's and 152 students in the Master of Psychology (Organisational and Human Factors), making a grand total of 920 students enrolled in applied psychology courses.

Many of the graduates from these programs are known to work, or to have worked, in a wide variety of jobs in government or commercial organisations or in their own businesses, where they have been able to utilise their knowledge and skills in applied psychology. As already indicated, a student research project in the master's program in organisational and human factors is currently being conducted to find out about the subsequent careers of as many as possible of the graduates from that program. Similar research projects in the other master's programs and for graduates of the diploma program would provide useful evidence on the contribution that those programs have made to the implementation of applied psychology in the local community and beyond.

Looking to the future, there are considerable challenges facing the teaching of applied psychology generally that need to be successfully dealt with if the present diversity in vocational training related to applied psychology is to be maintained and, ideally, expanded even further. These challenges include attracting more students into undergraduate psychology who know from high school psychology courses about the diverse career options in applied psychology; providing a one-year qualification in applied psychology without leading to registration, which would enable third-year graduate students unable to access honours to work in many different kinds of jobs that would benefit from basic knowledge and skills in applied psychology; and developing postgraduate pathways that provide specialised training in different fields of applied psychology, supported by supervised placements that allow even greater specialisation within a particular field of applied psychology. Economics and medicine are promising to make us all wealthy and healthy but, without a broad-based psychology applied to individuals, groups, organisations and society, our increasing wealth and health may be accompanied by increasing insecurity and alienation. Meeting the challenges, however, would enable applied psychology to continue to expand the positive contribution to individuals, groups, organisations and society that was envisaged by the founders of the discipline of psychology as an applied science. 


\section{References}

Anderson, KV. (1965). The Anderson report. Report of the Board of Inquiry into Scientology. Melbourne: Australia.

Antonergias, E. (1983). An audio-visual package for vocational-safety skills training in handicapped adults (Diploma of Applied Psychology thesis, University of Adelaide, Australia).

Ashenden, D. (2012, 22 November). Decline and fall? Inside Story. Retrieved from http:// insidestory.org.au/decline-and-fall.

Barkway, TJ, \& Kirby, N. (1983). The Australian industrial psychologist revisited. Australian Psychologist, 18, 331-344.

Cain, J, \& Hewitt, J. (2004) Off course: From public place to marketplace at Melbourne University. Melbourne: Scribe Publications.

Carless, S, Cuozin-Wood, C, Duncan, C, Imber, A, Munro, J, \& Novatsis, E. (2003). Practicum training for organisational psychologists: A survey of current and past students' attitudes. Australian Psychologist, 38, 55-61.

Chodkiewicz, N. (2016). Employment outcomes for graduates of an Australian Master of Organisational Psychology program (submitted Doctoral thesis, University of Adelaide, Australia).

Dawkins, J. (1987). Higher education: A policy discussion paper. Green paper. Canberra: Australian Government Publishing Service.

Dawkins, J. (1988). Higher education: A policy statement. White paper. Canberra: Australian Government Publishing Service.

Decker, P, Durand, R, Mayfield, CO, McCormack, C, Skinner, D, \& Perdue, G. (2012). Predicting implementation failure in organization change. Journal of Organizational Culture, Communications and Conflict, 16, 39-59.

Gold, M. (1980a). Try another way training manual. Champaign, IL: Research Press.

Gold, M. (1980b). Did I say that? Champaign, IL: Research Press.

Hampel, S. (2007). Exploring the training needs and capabilities of people with an intellectual disability: The need for formalised assessment (Honours thesis, University of Adelaide, Australia).

Hartstone, M. (1994). The Australian organisational psychologist: An update (Master of Applied Psychology thesis, University of Adelaide, Australia).

Hartstone, M, \& Kirby, N. (1998). The Australian organisational psychologist: An update. Australian Psychologist, 33, 68-75.

Hergenhahn, BR. (2009). An introduction to the history of psychology (6 $6^{\text {th }}$ ed.). London: Wadsworth/Cengage Learning.

Innovation and Business Skills Australia. (2011). Karpin report revisited: Leadership and management challenges in Australia. Australia: Department of Education, Employment and Workplace Relations.

Irvin, LK, Gersten, R, Taylor, VE, Close, DW, \& Bellamy, GT. (1981). Vocational skill assessment of severely mentally regarded adults. American Journal of Mental Deficiency, 85, 631-638.

Johnson, M, \& Stone, GL. (1989). Logic and nurture: Gender differences in thinking about psychotherapy. Professional Psychology: Research and Practice, 20, 123-127. 
Karpin, D. (1995). Enterprising nation: Renewing Australia's managers to meet the challenge of the Asia-Pacific Century. Report of the industry task force on leadership and management skills. Canberra: Australian Government Publishing Service.

Kimble, GA. (1984). Psychology's two cultures. American Psychologist, 39(8), 833-839.

Kirby, N. (1985). Technical and further education as a least restrictive alternative for disabled adults. Australian Disability Review, 4, 55-67.

Kirby, N, \& Hartstone, M. (1998). The role of the organisational psychologist: An update. Australian Psychologist, 33, 68-75.

Millear, P, \& Nugent, M. (2015, 2-4 July). Can workplace and personal resources counteract job insecurity in higher education employees? APS $11^{\text {th }}$ Industrial and Organisational Psychology Conference, Melbourne, Australia.

Munsterberg, H. (2012/1913). Psychology and industrial efficiency. Germany: Tredition Classics.

President's Panel on Mental Retardation. (1962). A proposed program for national action to combat mental retardation. Washington DC: US.

Psychology Board of Australia. (2015). Reviewing the psychology, education and training model: Preparing psychologists for practice and sustaining a skilled psychologist workforce for the future. Green paper. Australia: Psychology Board of Australia.

Sampson, D. (2011). Karpin Report revisited: Leadership and management challenges in Australia. Report. Melbourne: IBSA Innovation \& Business Skills Australia.

UQ Centre for Organisational Psychology. (2015, 16 February). Organisational psychology alumni survey. Queensland: University of Queensland. Retrieved from https://www.pfsc. uq.edu.au/page/pdf/UQAlumniSurveyReport-2015-02-16.pdf.

Welford, A. (1958) Ageing and human skills. London: Oxford University Press.

Welford, A. (1968). Fundamentals of skill. London: Methuen.

Witmer, L. (1907). Clinical psychology. The Psychological Clinic, 1, 1-9.

Yeatman, RJ, \& Sellar, WC. (1930). 1066 and all that: A memorable history of England. London: Methuen.

\section{Legislation}

Disability Services Act 1986 (Cth). Retrieved from https://www.legislation.gov.au/Series/ C2004A03370.

Disability Discrimination Act 1992 (Cth). Retrieved from https://www.legislation.gov.au/Series/ C2004A04426. 


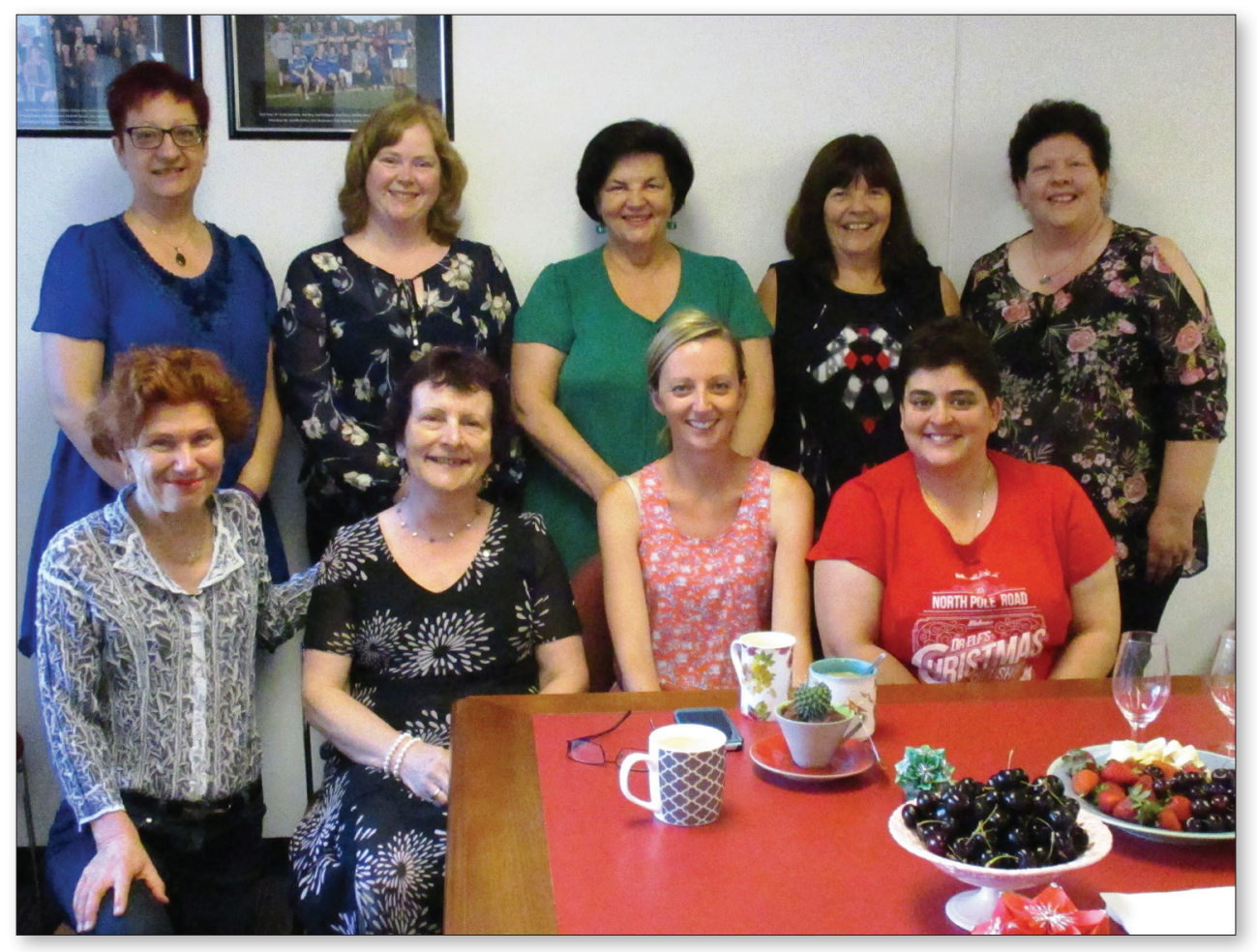

Figure 3.1 Professional staff, Christmas 2015; back row from left: Carmen Rayner, Kylie Pollitt, Wanda Prokopiak, Angela Allen, Deidre Simpson; front row: Janine Flory, Carola Sanders, Jessica Venning, Lynda Klopp.

Source: Courtesy of the author. 


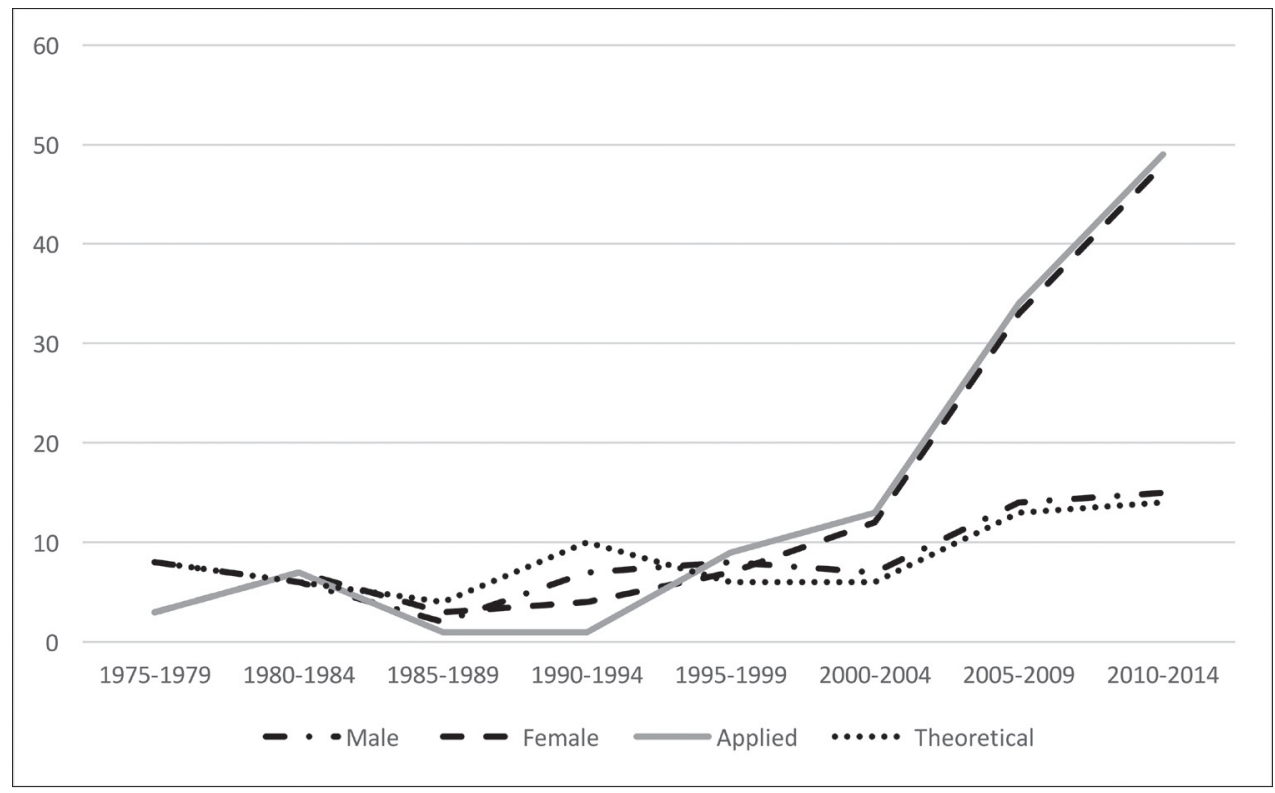

Figure 4.1 Percentages of female students in honours and master's courses. Source: Courtesy of the author.

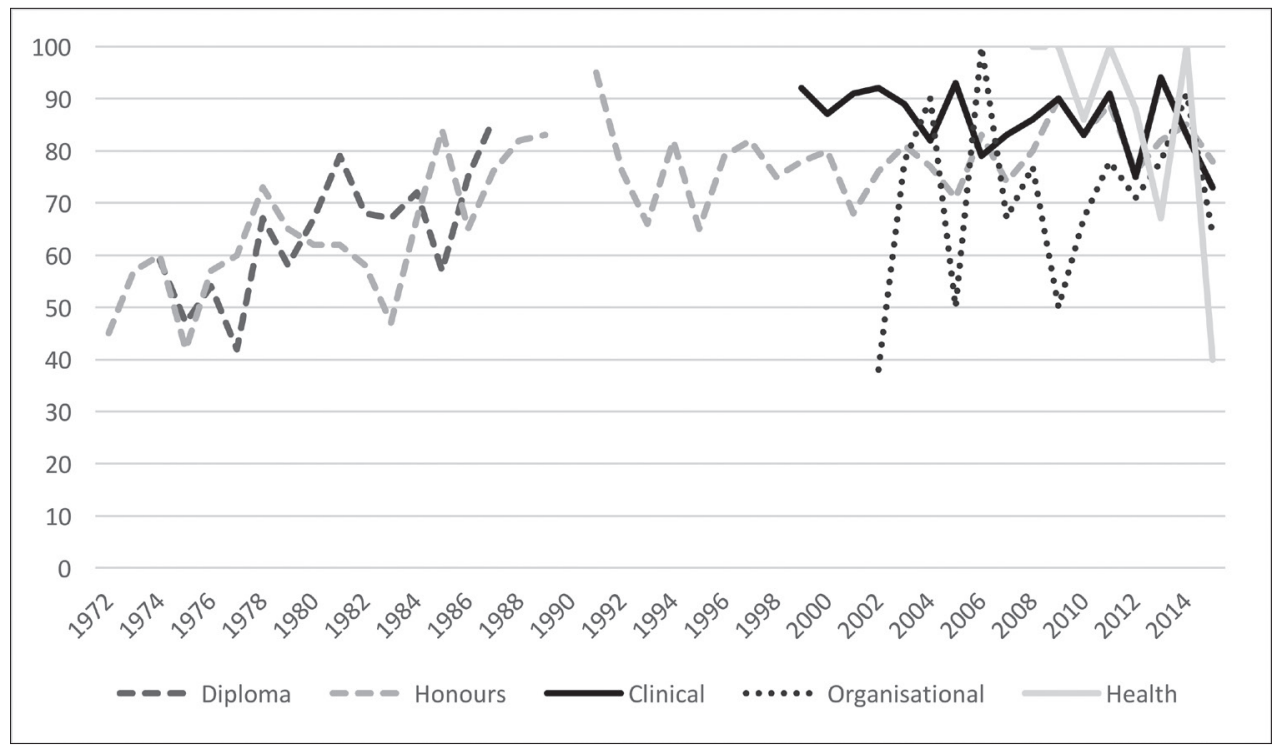

Figure 4.2 Totals for each five years of male and female PhD students and theoretical and applied theses.

Source: Courtesy of the author. 


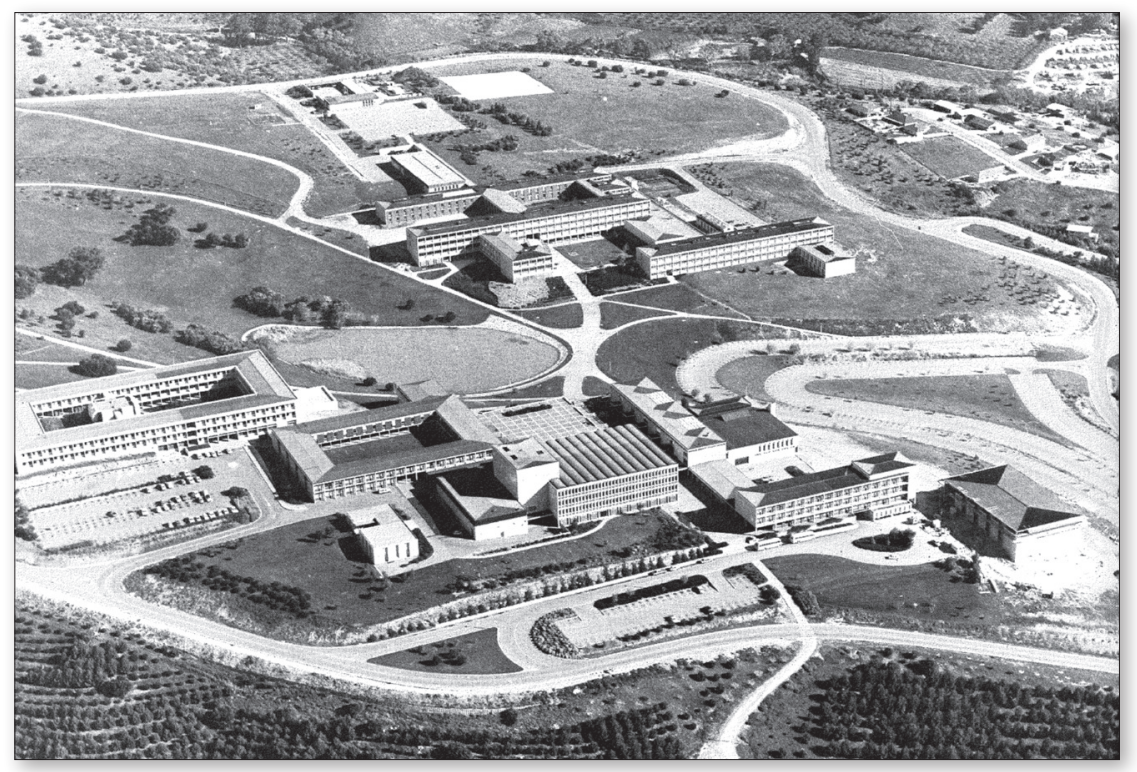

Figure 5.1 Flinders University in 1972. Psychology occupied the southwest corner of the newly completed Social Sciences building (furthest on the left). Source: The Flinders University of South Australia, Annual Report for the Year 1972.

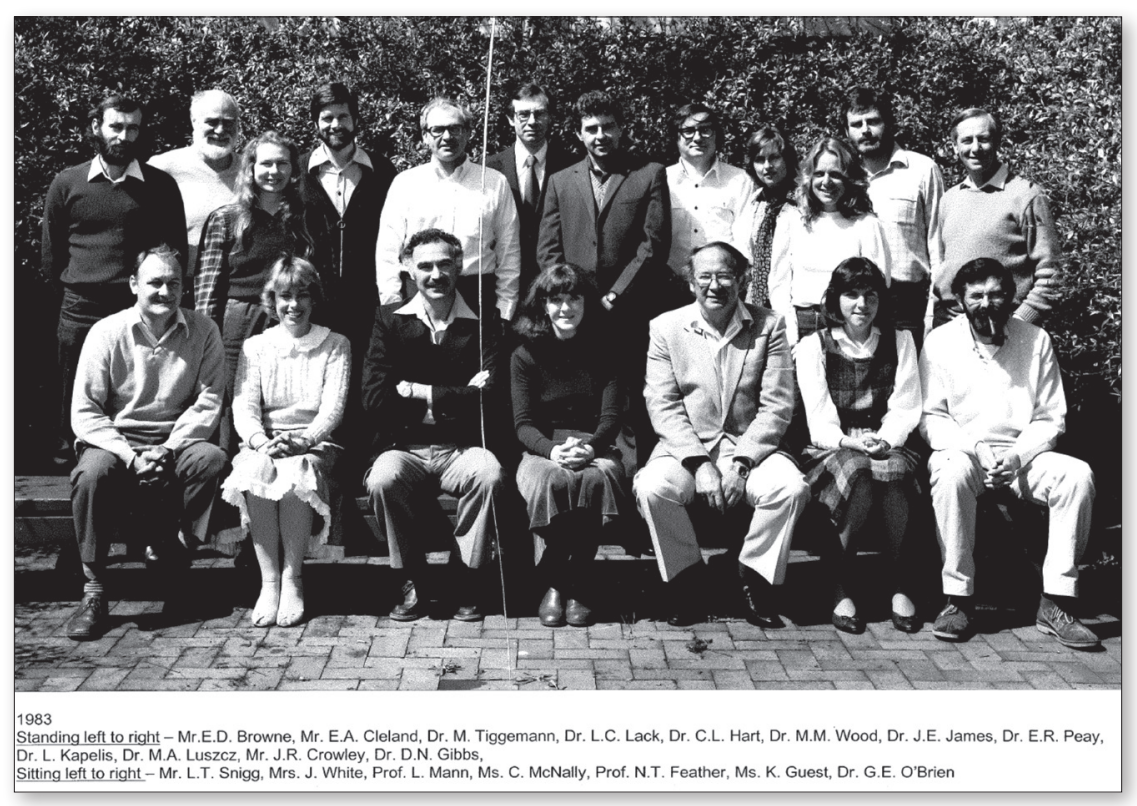

Figure 5.2 Annual staff photograph for 1983.

Source: Courtesy of the School of Psychology. 


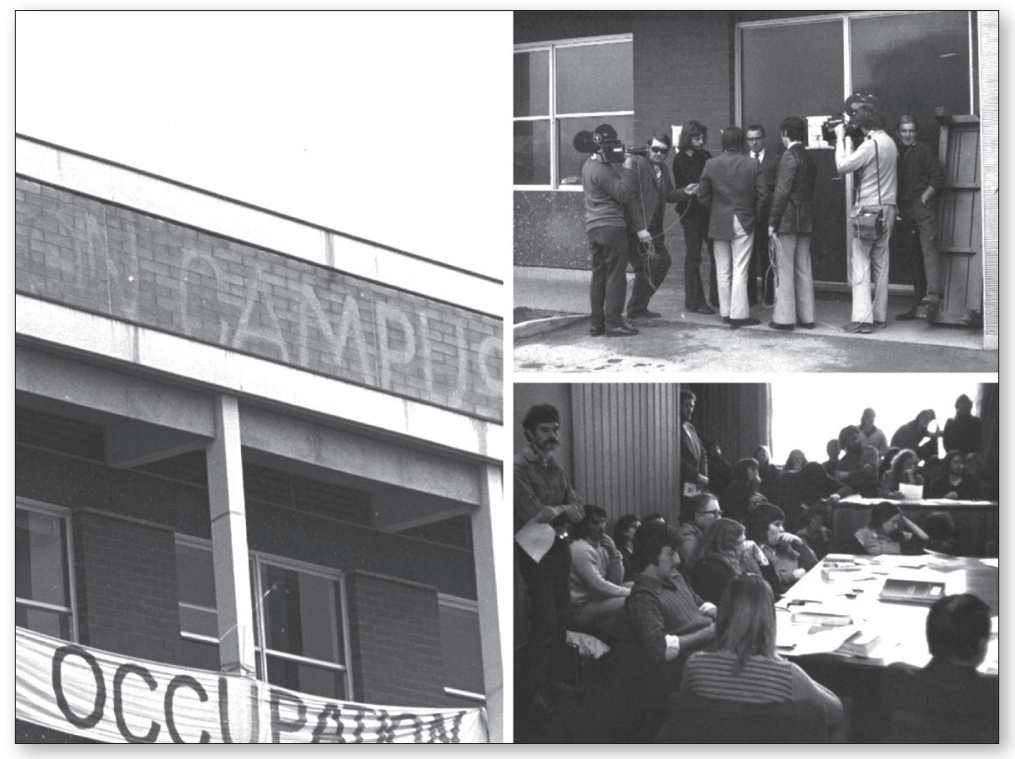

Figure 5.3 The occupation of the Registry.

Source: Flinders University Facebook online 04/11/2014, https://www.facebook. com/FlindersUniversity/photos/a.424867946169.200911.38691411169/1015282 7365806170/.

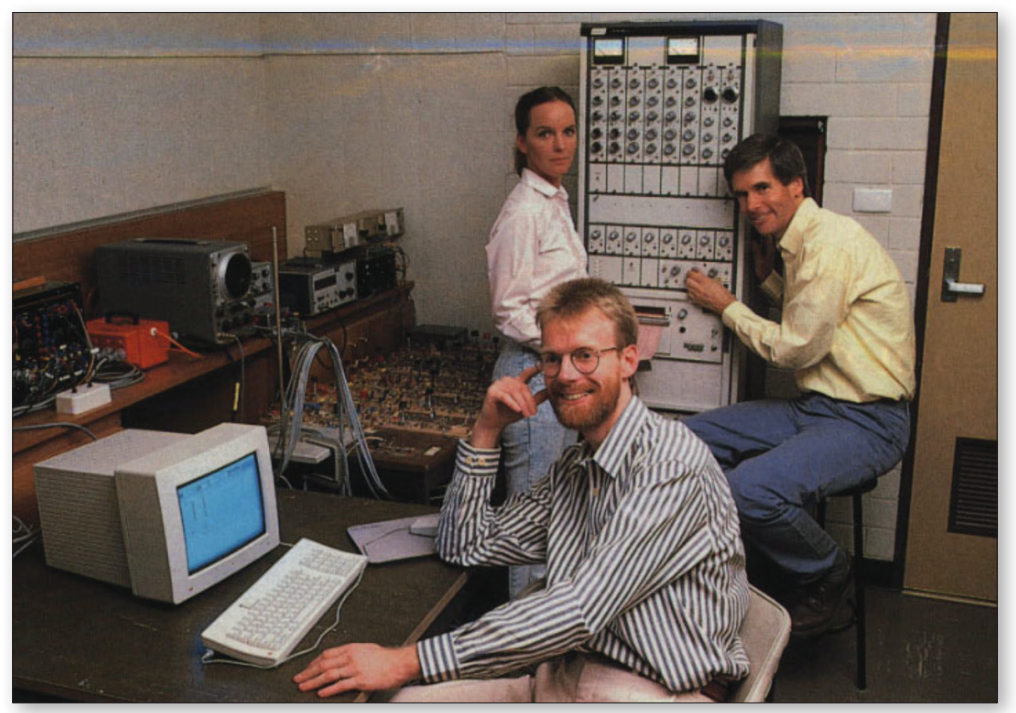

Figure 5.4 The Sleep Lab, 1988. The alpha biofeedback 'rats' nest' is on the table behind Mary Morris (now senior lecturer, Charles Darwin University). Leon Lack is at the M19 EEG machine, and Kurt Lushington (now head of the School of Psychology at the University of South Australia) is at the mighty Apple IIGS computer.

Source: Personal archives of Leon Lack. 


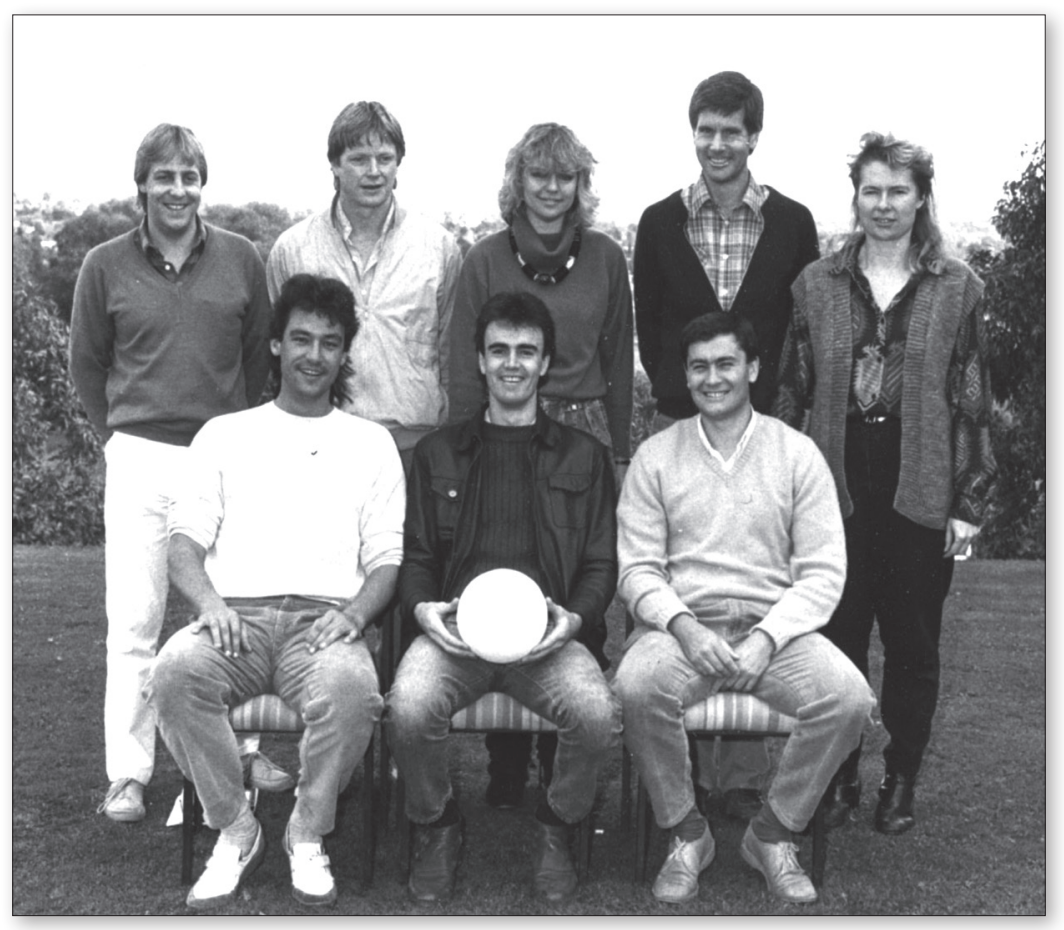

Figure 5.5 'Psychos': The Flinders Intramural International Rules Volleyball Champions, 1986. Back row, left to right: Dr Michael Proeve (Adelaide), Gary (an A league player), Loretta Daugalis, Emeritus Professor Leon Lack (Flinders), Professor Marika Tiggemann (Flinders). Front row, left to right: Professor Drew Dawson (Central Queensland University, Director of the Appleton Institute), Peter Ferris (professional actor who has played The Professor in lonesco's The Lesson but with more serious consequences for the student - that is, death - than Lack's staged mobile phone smashings from 2000-15, illustrating the 'fight-or-flight' physiological response for first-year students), and Associate Professor Chris Ball (William \& Mary, USA).

Source: Courtesy of the author. 


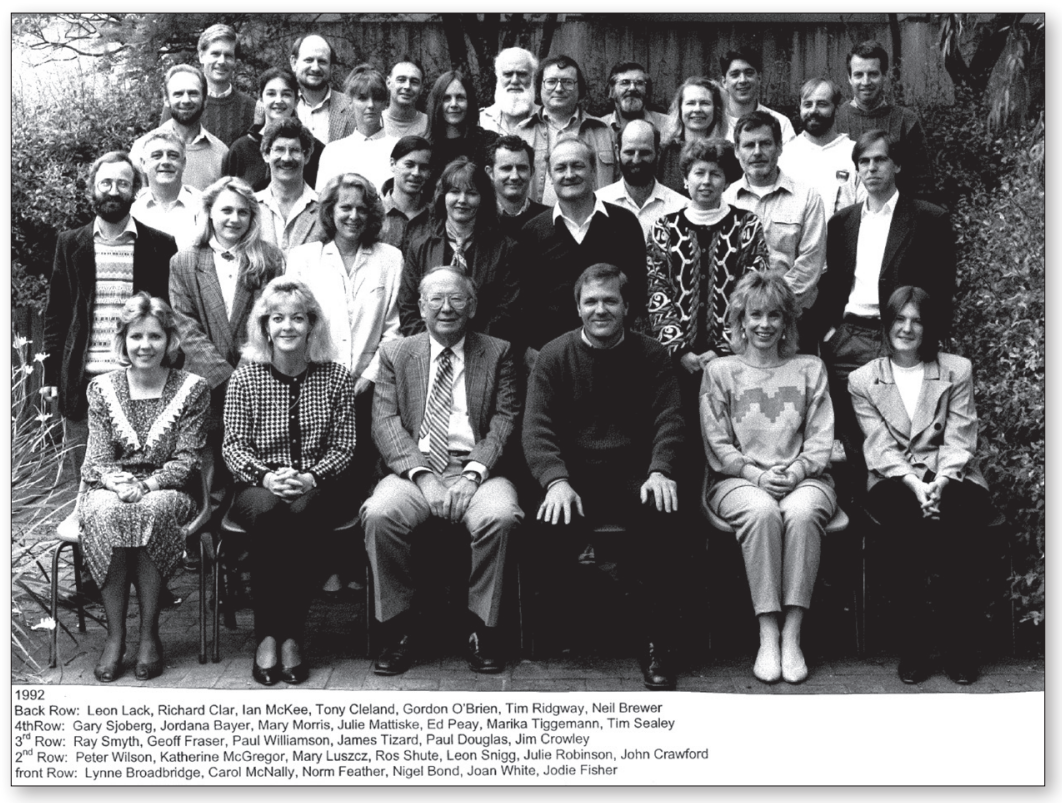

Figure 5.6 Annual staff photograph for 1992.

Source: Courtesy of the School of Psychology.

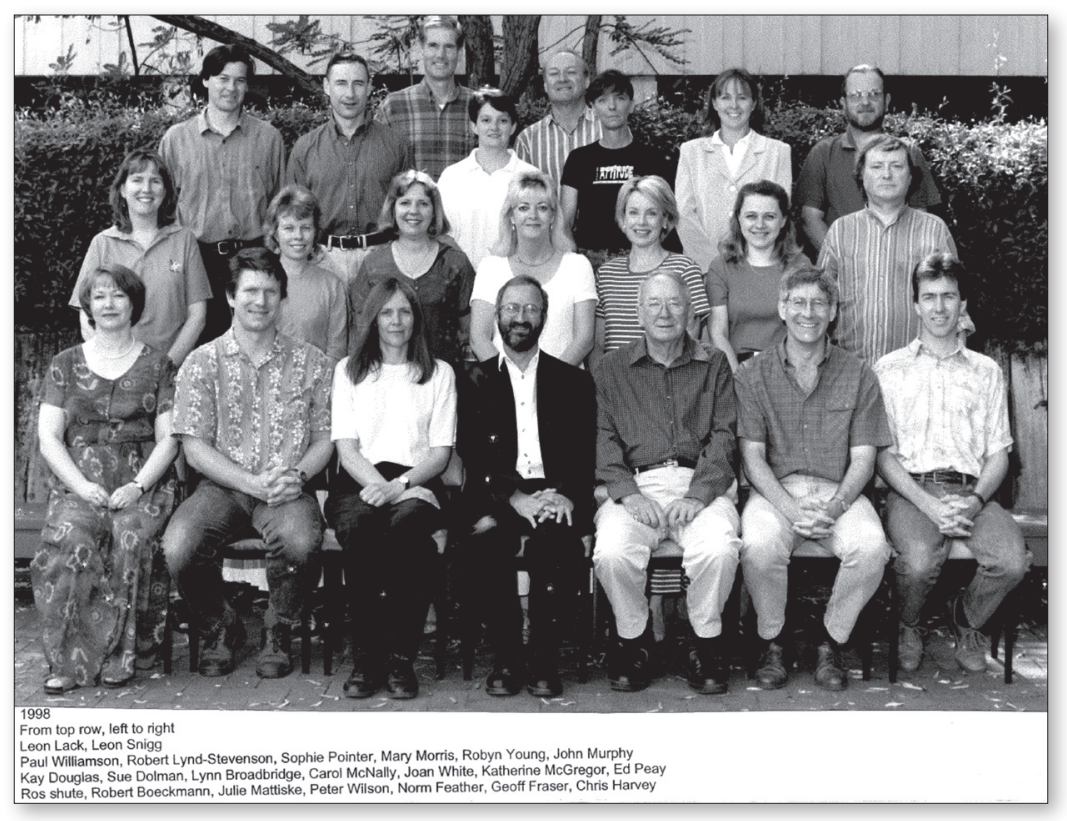

Figure 5.7 Annual staff photograph for 1998.

Source: Courtesy of the School of Psychology. 


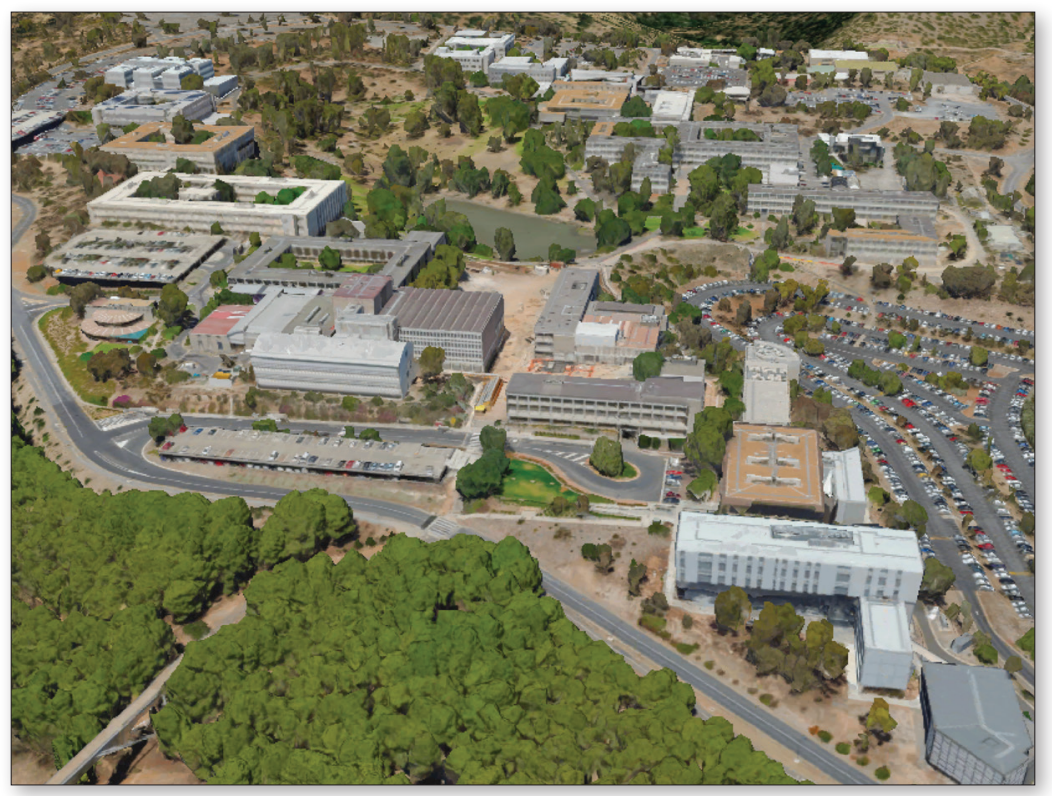

Figure 5.8 Aerial view of Flinders in 2015.

Source: Google Earth@ 2015.

1966 Flinders University established

1967 First intake of Psychology first year students; Appointment of Foundation Chair

1972 Master of Clinical Psychology program (Norm Feather) commenced

198718 full time academic staff working in the School

$198613 \mathrm{PhD}$ completions - a rate of 1.5 per year 1990s PhDs completions at a rate of 1.5 per year

r

2008 Psychology recognised as an area of strategic research strength in the university and awarded ongoing funding as a research centre; strengths across five domains recognised: (1) Clinical \& Health, (2) Developmental, (3) Memory \& Cognition, (4) Neuroscience \&

$$
\text { Psychophysiology, (5) Social }
$$

2000s $\mathrm{PhD}$ completions at a rate of 5.9 per year 2002 Clinical PhD introduced

2010 onwards $\mathrm{PhD}$ completions at a rate of 7.5 per year
2010 Five additional staff positions approved by the University: 2 Flinders Foundation professors and 3 Level B positions

201123 FTE ongoing appointments at Level B or above

Figure 6.1 Snapshot of the historical timeline for the School of Psychology, Flinders University.

Source: Courtesy of the author. 


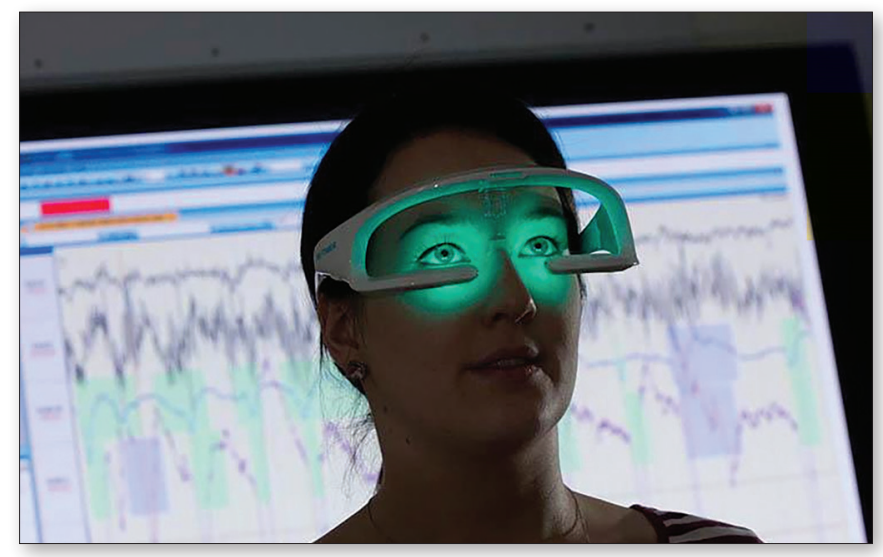

Figure 6.2 Re-timer.com, available for effecting body clock mis-timing treatments (e.g. body clock sleep disorders, jet-lag, shiftwork, and winter depression).

Source: Courtesy of the author.

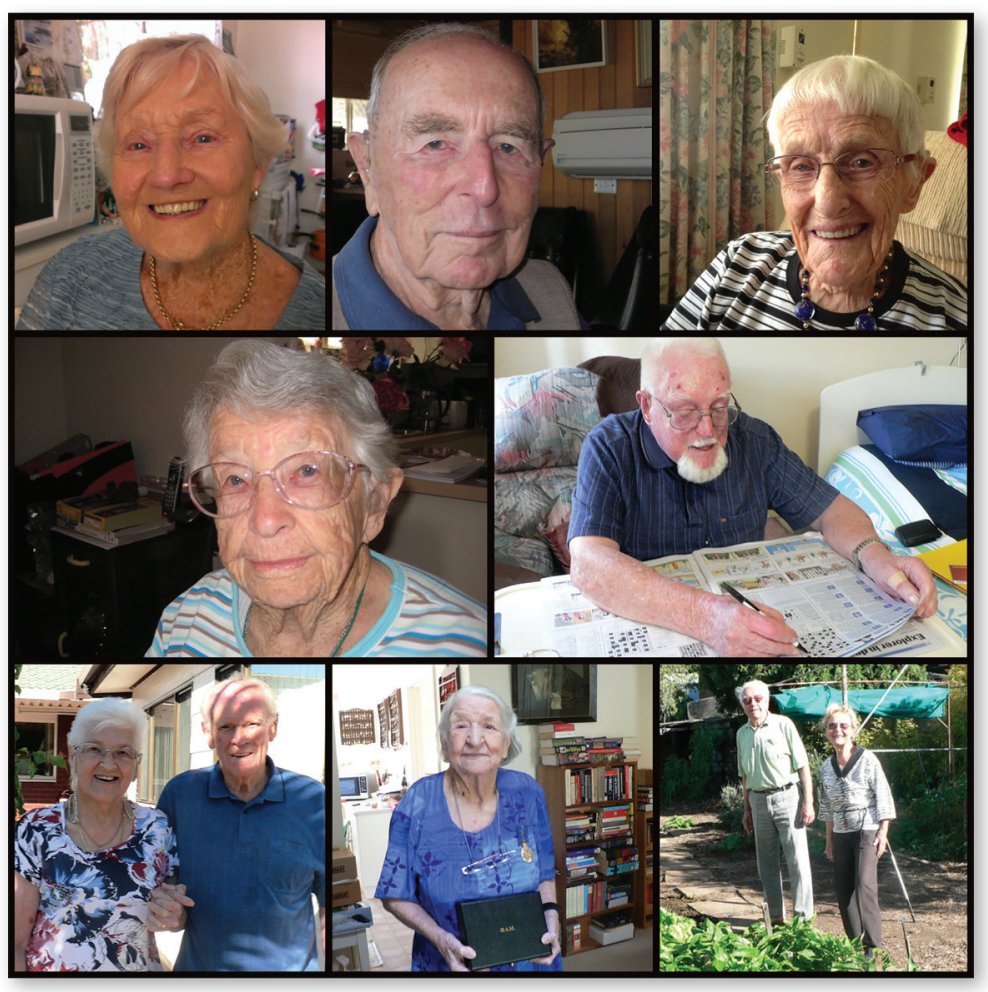

Figure 6.3 Australian Longitudinal Study of Ageing (ALSA).

Source: Courtesy of the author. 


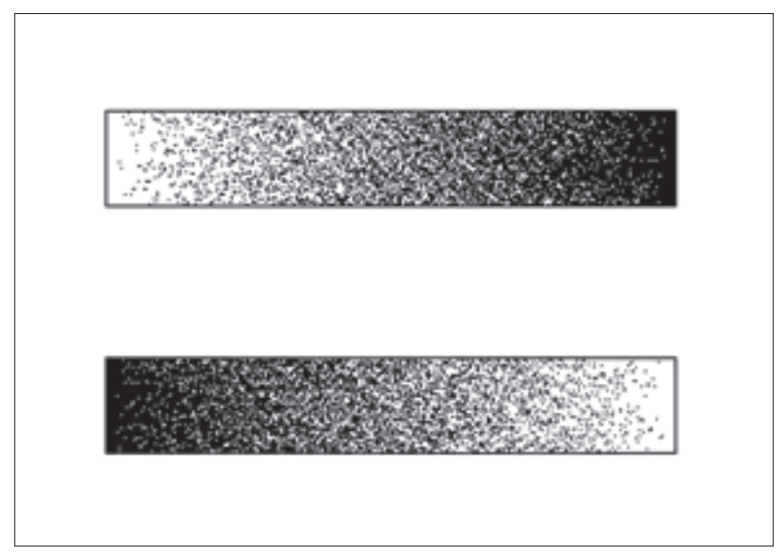

Figure 6.4 The greyscales stimuli. Which one looks darker overall? Despite being equiluminant, most people pick the stimulus that is dark on the left-hand side.

Source: Courtesy of the author.

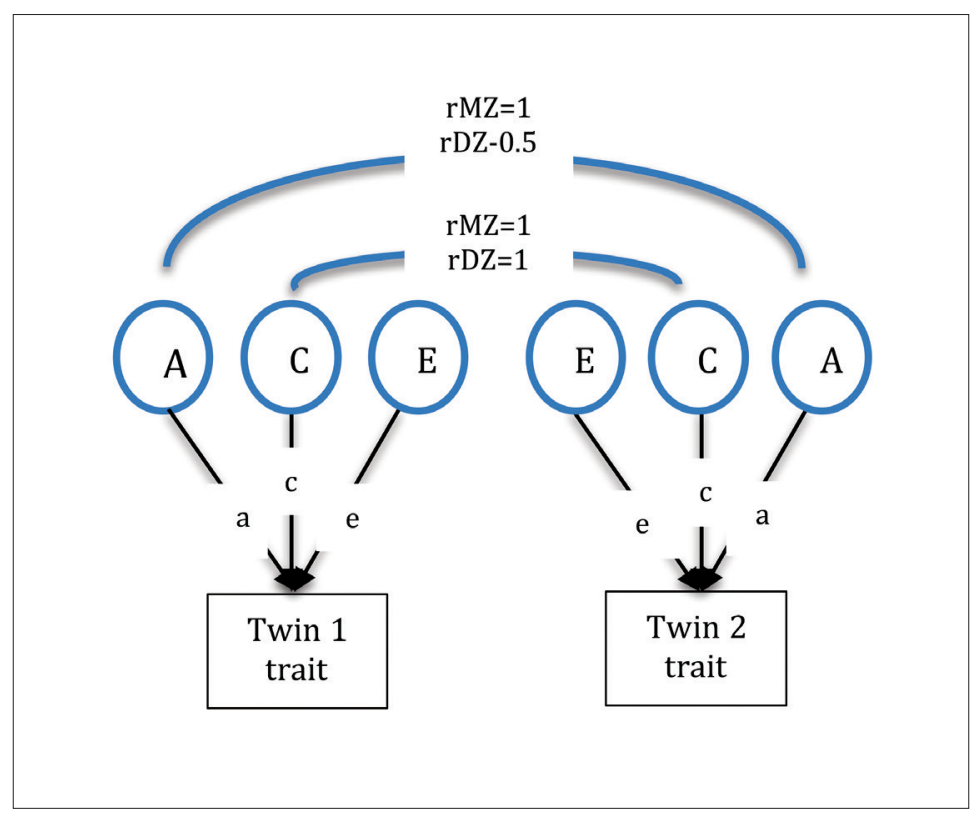

Figure 6.5 The classic twin model, recognising that monozygotic (MZ) twins share $100 \%$ of their genes and dizygotic (DZ) share on average $50 \%$ of their genes, denoted by $A$ in the diagram (additive genetic action); $\mathrm{C}=$ shared or common environment and $\mathrm{E}=$ non-shared environment.

Source: Courtesy of the author. 


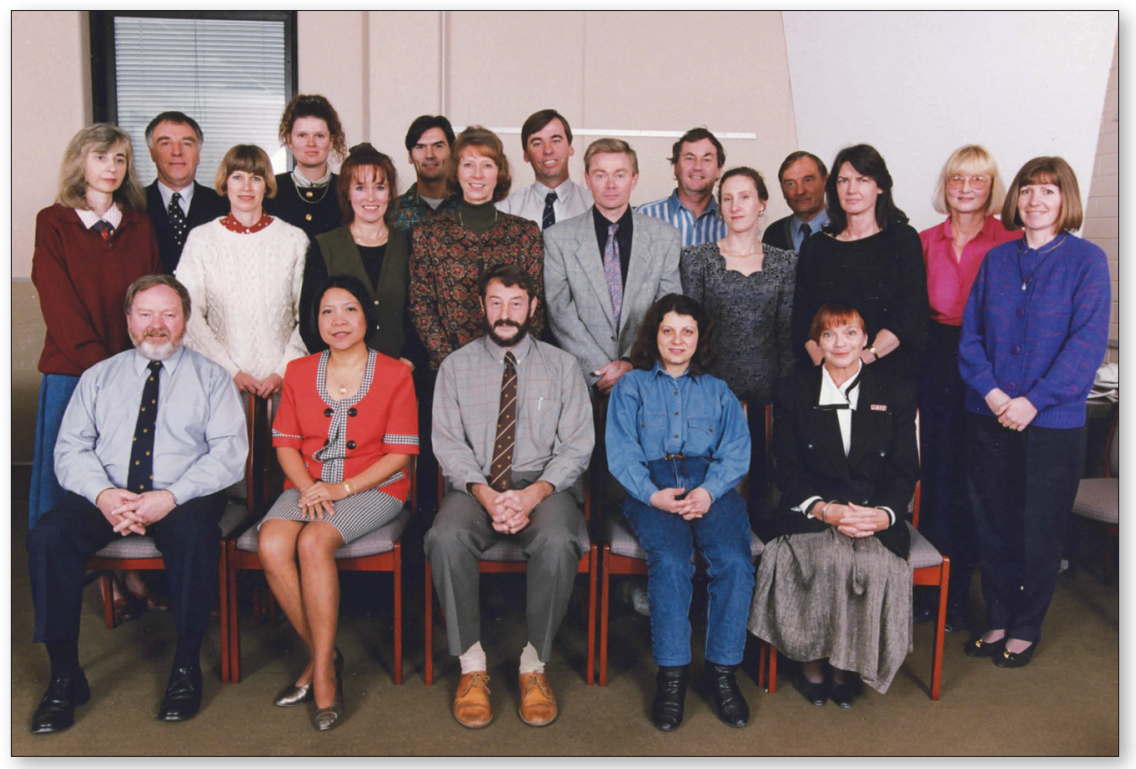

Figure 7.1 Some of the staff of the school in 1994. Front row, left to right: Brian Gerner, Monnette Garcia, Dr Jacques Metzer; Josie Luscrie, Carolyne Halliday. Middle row, left to right: Dr Catherine Delin, Denise Skinner, Melanie O'Brien, Glenys Russell, Dr Phil Mohr, Cathy Balfour, Biruta Dietz, Jan Honeyman. Back row, left to right: Prof Jim Gaite, Sue Boord, Mark Cescato, Greg Ireland, Dr David Haynes, Associate Professor Ralph Hood, Ilona Reid.

Source: Courtesy of the School of Psychology.

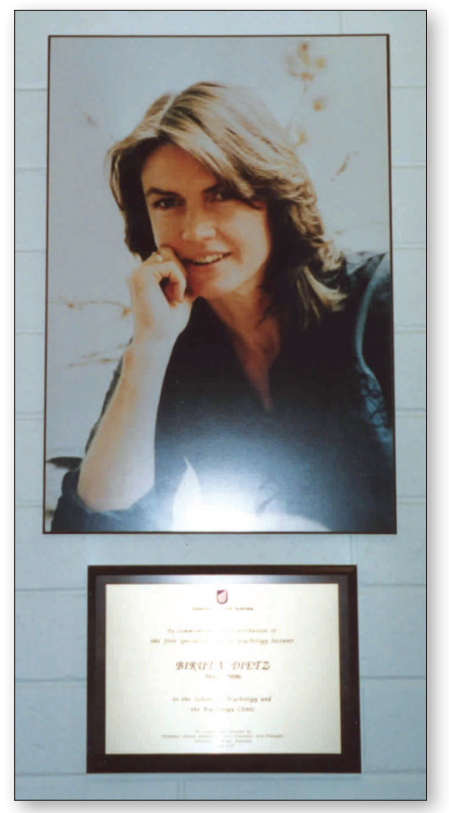

Figure 7.2 Photograph of Biruta Dietz and plaque at the City East Psychology Clinic.

Source: Christian Dietz, used with permission. 


\title{
Flinders University: Psychology in the twentieth century
}

\author{
Leon Lack
}

\section{Note}

This chapter was compiled and edited by Leon Lack, but contains contributions (as listed in the relevant sections below) from Norman Feather, Paul Douglas, Nigel Bond and Peter Wilson.

\section{Introduction}

\section{Leon Lack}

Given my longevity in the Discipline/Department/School of Psychology from 1971 through to the present, and given that I have viewed its operation at all academic levels from senior tutor on up, it was perhaps appropriate that I was asked to be responsible for getting together observations of the history of this period. It was also fitting that we hear from the perspective of the heads of the unit across this period of time particularly Professor Norm Feather, the founding professor and head for perhaps the longest period, who is still present most days of the week as emeritus professor, sixteen years after retirement and into his eighties. Included also is a contribution from Professor Nigel Bond, head from 1992-96, and Professor Peter Wilson, head from 1997-2001.

These contributions are woven together with snippets of other aspects of psychology at Flinders - aspects that are less a part of the formal history, but may give a more visceral feel of the place and people across the twentieth century. 
We start appropriately with a piece from Professor Norman (Norm) Feather, which draws on an article that he published in the Bulletin of the Australian Psychological Society (1995). He revised the material for this volume to bring it up to date and it is presented here as a personal record.

\section{The early years}

\section{Norman Feather}

The establishment of psychology as an academic discipline at Flinders University occurred in the context of the discussion about what kind of academic structure the new university should adopt and where psychology would fit within that structure. Eventually, in an attempt to facilitate links between disciplines and to break away from old structures, it was decided to establish a number of schools rather than faculties. Psychology was located in the School of Social Sciences, along with other disciplines that included history, politics, social administration, geography, and economics. There was a firm belief that the new university, formerly the Bedford Park adjunct of the University of Adelaide, should be different from its 'mother' institution in its form and structure and that the schools and disciplines within it should also pursue distinctive aims. $^{6}$

The Flinders University of South Australia was established in 1966. New universities were being created post-war as a legacy of the Menzies era of politics and the time was ripe for new ideas. The university was initially organised into four schools: Language and Literature, Social Sciences, Physical Sciences, and Biological Sciences. There were just over 400 students and approximately ninety academic staff when the university was opened in 1966. Now, in 2015, there are over 26000 students, and the number of academic and general staff has expanded rapidly over the fifty years since Flinders was established to more than 2700. In this period, it has developed into a major institution with a fine record of teaching and research.

Locating psychology in the School of Social Sciences at the time of the university's establishment signalled that the focus would be on social psychology and on those aspects of the discipline which would assist in developing a deeper understanding of the social sciences in general. There was a strong emphasis on promoting interdisciplinary enquiry and a belief that this aim could be achieved at the undergraduate level by including compulsory multidisciplinary degree requirements in the curriculum. The social sciences were seen as a unified set of disciplines. In the early years, there were

6 Interestingly, the premier of South Australia at the time was Sir Thomas Playford, who apparently wanted to see the second university in South Australia established in a regional centre strongly supported by his Liberal Country League party. The loss of the 1965 state election to the Labor Party may have been the political impetus to allow Flinders to be declared a university in its own right. 
many debates in the School of Social Sciences about the need to safeguard the so-called unity of the social sciences and the importance of establishing cross-linkages between the various disciplines.

Proponents of a basic unity viewpoint had difficulty in specifying where the unity resided unless it was at the general level of studying people in society. In 1966, the disciplines in the School of Social Sciences included economics, geography, history, political theory and institutions, and social administration. Psychology and education were added the following year and sociology came later. These disciplines clearly differed in their content and interests and in the methodologies they used. In the case of psychology, the problem was compounded because psychology has a biological as well as a social basis and a strong tradition of laboratory research involving instrumentation and experimental techniques. From the start, it was evident that psychology would not have an entirely comfortable home in the School of Social Sciences, and the question of its proper location has remained an issue throughout the history of the university. Currently, it is located in the Faculty of Social and Behavioural Sciences, a dramatic change in emphasis from its initial identification as purely a social science.

Although teaching at the new university began in 1966, it was delayed in the case of psychology as the search proceeded for a foundation professor. Initially, the position was advertised as a chair in social psychology. I was approached as a possible appointee by the vice-chancellor, Peter Karmel, late in 1966 while I was at the University of New England, but I was committed to a year's sabbatical leave at the University of Michigan and had some misgivings about the specialist title. Subsequently, the position was advertised as a chair in psychology and I was appointed to this foundation chair in 1967. I commenced duties in 1968. Teaching of the first intake of first-year students had already begun in 1967 , conducted by a visitor to the new university, John Chadwick-Jones.

I came to the position determined to set up a strong psychology presence at Flinders University with an emphasis on social psychology, as distinct from the emphasis on human performance and animal learning which prevailed at the University of Adelaide. I had completed postgraduate studies at the University of Michigan in 1960 and subsequently, while at the University of New England, I had co-edited a classic book on achievement motivation with John W Atkinson from the University of Michigan (Atkinson \& Feather, 1966). I was committed to the view that social psychology could not be taught in isolation and that its proper development depended on an understanding of the basic processes of learning, perception, cognition and motivation, and also on knowledge about human development and individual differences in personality and intelligence. That is, students should be exposed to what Lee Cronbach (1957) called the two disciplines of scientific psychology. 
So the early development of what was then called the Discipline of Psychology involved the appointment of academic staff with special interests and expertise in personality (David Gibbs), experimental psychology (Frank Ledwith), human skills (Denis Glencross), learning (Tony Cleland and Charles Hart), cognition (Jim Crowley), social psychology (Ed Peay and Stanley Morse), perception and physiological psychology (Leon Lack), environmental psychology (Arthur Shurcliff) and organisational psychology (Gordon O'Brien). Over these early years, the curriculum included a wide and representative set of topics that were offered at undergraduate level, but there was a strong commitment to the social/personality side of the discipline and a commitment to ensure that social and personality psychology occupied an important place in the topics that were taught and in the research that was conducted.

There were no postgraduate courses in clinical psychology in South Australia when psychology was founded at Flinders University. Representations were soon received from the professional community in Adelaide to establish these courses at Flinders. They were clearly needed. John Court was appointed in 1971 to plan and co-ordinate them, and he was subsequently joined by Lia Kapelis in 1973. The two-year Master of Psychology program began in 1972, when the first group of students enrolled for the degree. Over the years, this program has continued to turn out many well-trained graduates in clinical psychology, who have helped to raise the profile of clinical psychology in South Australia and elsewhere in Australia. Following John Court, the MPsych program in clinical psychology was co-ordinated by Mike Wood, who was appointed in 1977, and also by Jack James, who was appointed in 1983. John Court resigned in 1982 to go to the US; Mike Wood left in 1993 to take up an appointment with the University of New South Wales; and Jack James resigned in 1990, when he was appointed to a chair in psychology at the Lincoln Institute in Melbourne (La Trobe University).

The clinical program was then co-ordinated by Peter Wilson, who was appointed in December 1991. Students were able to progress from the MPsych to a PhD in clinical psychology. Academic staff who taught on the MPsych program included John Court, David Gibbs, Lia Kapelis, Mike Wood, Jack James, Gina Geffen, Charles Hart, Peter Wilson, Ros Shute, Leon Lack, John Crawford, Marika Tiggemann, Tony Cleland and Chris Cronin. Staff with primary teaching responsibilities on the MPsych course were expected to make a contribution to undergraduate teaching as well, so that they would be fully conversant with the teaching concerns and educational aims of the discipline as a whole, and so that professional courses would not be separated from the 'bread and butter' core teaching of the discipline. The reverse also applied. Staff with primary teaching responsibilities at the undergraduate and honours levels also contributed to the MPsych course by thesis supervision or by occasional lectures and seminars.

An MPsych course in educational psychology was later initiated by Mike Wood. It was brought to fruition in 1988 by Lynn Pelco (now at the College of William and 
Mary in the US). This course involved a mixture of topics taught by staff from the School of Education as well as selected topics from the MPsych clinical program. After her arrival in 1991, Ros Shute took over co-ordination of this program.

As part of the development of applied psychology at Flinders University, a fourth-year Diploma in Applied Psychology course was introduced in the mid-1970s. For various reasons, it was discontinued in the mid-1980s; instead, some applied psychology topics were added to the honours program to broaden its scope.

Social psychology in the discipline was strengthened by the appointment of Leon Mann, first as reader in psychology in 1972 and then as the second professor in 1973. Over the years, we took turns as head of discipline on a three-year basis and the arrangement worked very well, allowing us to maintain an active research program despite the demands of administration. During those years, teaching and research in social psychology at Flinders University was at its peak. Leon Mann introduced courses in decision making and collective behaviour, and at one stage we jointly offered a course in cross-cultural psychology; we planned to consolidate this topic with the appointments of Julie Robinson and Chris Cronin.

Meanwhile, I taught courses in human motivation and current issues in social psychology at the higher levels, as well as taking some lectures on human motivation in the introductory course. My involvement with the introductory course was premised on the belief that professors and other experienced senior staff should take the lead in what is probably the most demanding teaching assignment in psychology — that is, getting the large first-year class interested in, and informed about, psychology without sacrificing standards. Mann served the discipline very ably for eighteen years, and we enjoyed a fruitful and always friendly collaboration during which the discipline developed in depth and maturity. He left in 1990 to take up an appointment as professor in the Graduate School of Management at the University of Melbourne.

Social psychology was also advanced in other ways. In 1972, with Leon Mann, I conceived the idea of organising a mini-conference on social psychology, which would meet each year. We christened it the Flinders Conference on Social Psychology and hoped that it would provide a forum in which social psychologists could present the results of their investigations and also discuss proposed research and report on research-in-progress. Impetus for the conference was the presence of a 'critical mass' of social psychologists at Flinders, recognised as a major centre of social psychology in Australia. There was also recognition that a specialist meeting of social psychologists was needed to help develop the field in Australia. The first meeting was held over a weekend at Flinders University in May 1972, with participants accommodated in the Flinders Hall of Residence. Over thirty social psychologists from many parts of Australia attended. The conference was fortunate in having Bob Rosenthal from Harvard University as a visitor, along with a program of interesting papers. 
It was decided at that meeting to organise the conference as an annual event and to hold it in different centres each year, where there were active social psychology groups. Thus the conference quickly lost its initial Flinders title and acquired a more general ownership. The annual meeting of social psychologists has continued over the years, with meetings held in cities as far apart as Cairns, Hobart, Newcastle, Perth, Christchurch and Auckland. As this conference increased in size, it became more formal, and in 1995 it was constituted into a voluntary incorporated association called the Society of Australasian Social Psychologists, to represent both Australian and New Zealand social psychologists. The annual meeting is an important event for social psychologists in Australia, and psychology at Flinders can be proud of the fact that it began there.

Courses in social psychology were supplemented by topics in organisational psychology, initiated by Gordon O'Brien, who was appointed as a senior lecturer in 1969 and later promoted to a readership. O'Brien received the Elton May Award in 1990 for his contributions to organisational psychology. He was also the author of an influential book on work and unemployment (O'Brien, 1986), and during the 1980s he collaborated with me in research on the psychological effects of unemployment.

These early developments in social, clinical and organisational psychology were accompanied by the introduction of courses in various fields of experimental psychology. Denis Glencross set up a laboratory for teaching and research in human performance. He was also a pioneer in sports psychology in Australia. He left Flinders University in 1988 to take up an appointment to the foundation chair of psychology at Curtin University, where he served until his untimely death in 1994.

Gina Geffen established a neuropsychology laboratory at Flinders and was appointed to the Julia Farr Chair of Neuropsychology in 1988, following negotiation of an agreement between the Julia Farr Centre in Adelaide and Flinders University. As part of that agreement, she was expected to develop research in neuropsychology and related areas at the Julia Farr Centre, which was a hospital for people with disabilities. She left Flinders University in 1991 to take up a professorial position at the University of Queensland. She was replaced at Flinders by John Crawford, who continued the association with the Julia Farr Centre until the agreement lapsed in 1995 because of changing circumstances at the hospital. Teaching and research in neuropsychology were also developed by Richard Clark, who established a sophisticated computerised laboratory to support these activities.

Leon Lack initiated courses in physiological psychology and sleep disorders in the discipline and over time built up a computerised sleep laboratory for physiological recording. He was later promoted to a professorship. Teaching in other aspects of experimental psychology and research methods also involved Tony Cleland, Charles Hart, Ed Peay and Jim Crowley. 
In 1980, courses in child development were expanded by Mary Luszcz. She introduced topics in the field of lifespan development and ageing, and her contributions were recognised by promotion to readership and later to a professorship. Other contributors to the teaching of developmental psychology included Lynn Pelco, Ros Shute and Julie Robinson.

The Discipline of Psychology was subjected to external review in 1987. One recommendation was that a new professorial appointment be made in an area of experimental psychology appropriate to the needs and interests of the discipline. Nigel Bond was appointed to this chair in 1992. He came to the discipline with a strong background in the psychology of learning, in drug and alcohol effects, and in biological aspects of experimental psychology. In the same year, psychology became a school in the newly created Faculty of Social Sciences. Psychology had sought autonomous school status for many years in the hope of obtaining more control in determining the structure of its courses and more power to argue for an equitable allocation of resources to psychology.

Although psychology's primary teaching responsibilities were within the School (now Faculty) of Social Sciences, the discipline also contributed to other parts of the university. Academic staff in psychology collaborated with the School of Medicine in teaching some clinical courses that required psychological expertise, and also in medical research in particular areas (for example, pain studies). Staff from the School of Biological Sciences assisted psychology in the provision of courses in psychobiology and physiological psychology. Indeed, Roger Russell, who followed Peter Karmel as vice-chancellor, held the position of professor of psychobiology and gave occasional lectures in the discipline. There were links with the School of Education which continued in the MPsych course in educational psychology. Psychology also participated with other disciplines within the School of Social Sciences to provide multidisciplinary topics (for example, on decision making and on ageing).

\section{Research at Flinders}

\section{Norman Feather}

So far I have concentrated mainly on the early history of the teaching programs in psychology at Flinders and on the academic staff who were responsible for their development. From the very start, however, psychology at Flinders University had a very strong research emphasis. It was the policy to appoint staff with a demonstrated interest in, and capacity for, first-rate research, in the belief that universities have a duty not only to transmit reliable knowledge to students but also to be centrally engaged in the pursuit of new ideas. The School of Psychology had from the beginning an excellent record of research activity in many different areas, and produced postgraduate 
research students in a variety of fields, some of whom have gone on to high-level academic and professional positions.

The standard was set by the research output of the first two professors. As noted previously, I came to Flinders having co-edited an influential book on achievement motivation. In 1974, while on leave at Harvard University, I completed a book on the psychology of values (1975), which brought together a program of research on values that I had conducted at Flinders University. Next, I edited a book on expectations and actions, which included chapters by researchers who used concepts of expectation (or subjective probability) and incentive value (or utility) in the research that they conducted (1982). This was followed in 1990 by a monograph on the psychological impact of unemployment, which described a program of research on unemployment effects that I conducted in the 1980s.

I have continued to be productive in research, with a book on values, achievement, justice and deservingness (1999) and over 240 articles published in national and international journals. Some of my other research has focused on balance theory, tall poppy attitudes, prejudice, cultural cringe, causal attribution, gender roles, deservingness and emotions, and schadenfreude. I was elected to the Social Science Research Council (now the Academy of the Social Sciences in Australia) in 1970 and I am the recipient of two honorary degrees (one from the University of New England and the other from Flinders University), as well as other awards, which include an honorary fellowship of the Australian Psychological Society. I was a recipient of a Member of the Order of Australia (AM) award in the national honours list published on Australia Day in 2016.

Leon Mann brought to Flinders an expert knowledge of the psychology of decision making, as well as expertise in many areas of social psychology. He completed his postgraduate studies at Yale University and subsequently held appointments at Harvard University and the University of Sydney. He published an introductory text on social psychology (1969) which was widely used in Australian universities. While at Flinders, he co-authored with Irving Janis a groundbreaking book on decision making (1977), which clarified variables that affect the quality of the decisions that people make. He served as editor of the Australian Journal of Psychology and was elected to the Academy of the Social Sciences in 1975, subsequently becoming its president. Among many other distinctions and achievements, he is the recipient of an honorary degree from the University of Melbourne, his alma mater. He was a recipient of an Officer of the Order of Australia (AO) award in the 2016 Australia Day national honours list.

There was a diversity of research topics conducted by other members of the discipline in these early years in addition to the research in social psychology just described. Research was conducted into ageing; sleep disorders; policing and forensic psychology; behaviour modification; clinical disorders; skilled behaviour; youth 
unemployment; drug, caffeine and alcohol effects; neuropsychology; and evoked and event-related brain potentials; as well as some survey research in Adelaide. This list is not exhaustive.

The publication rate among staff was relatively high by national and international standards. When I attended the $25^{\text {th }}$ International Congress of Psychology in Brussels in 1992, I noted an analysis of the highest-impact institutions in psychology by Eugene Garfield, the executive officer of the Institute for Scientific Information [ISI]. The analysis appeared in the daily news sheet of the congress, with the measure of impact being based on citation counts and the number of papers published from 1986 through 1990. The psychology discipline at Flinders University was the only Australian institution to make the list.

Psychology at Flinders continues to be very productive in research. It has also contributed in important ways to the profession at the national level. I was president of the Australian Psychological Society [APS] in 1978-79 and Leon Mann held that office in 1987-88. Staff in the discipline also undertook editorial responsibilities. I was an associate editor of the Australian Journal of Psychology from 1972 to 1978; Gordon O'Brien was an associate editor from 1978 to 1981; Mike Wood was an associate editor from 1979 to 1986; and Leon Mann was editor of this journal from 1982 to 1986. Some staff also served on the editorial boards of major international journals. Three members of the discipline were elected as fellows of the Academy of the Social Sciences in Australia: myself in 1970, Leon Mann in 1975 and Gina Geffen in 1990. In later years Neil Brewer, Mary Luszcz, Marika Tiggemann and Tracy Wade were also elected to the academy. Other members of the discipline (school) contributed in valuable ways to APS committees at the local and national level and to the Adelaide community as consultants on various issues.

Over the first years of psychology at Flinders, many distinguished overseas visitors were welcomed to the discipline. Some came through Adelaide during short visits to Australia and participated in the weekly staff seminar. Others stayed longer. For example, Irving Janis conducted a workshop on decision making in conjunction with Leon Mann in 1983, and Richard Bootzin conducted a workshop on sleep research in 1995. Dick Bootzin returned to Flinders on two further occasions over a twelve-year period to collaborate with Leon Lack in three successful bids for large research grants from the National Health and Medical Research Council for the study of insomnia and its more effective non-drug treatment. John R Anderson and Lynne Reder visited the discipline on two occasions and worked on publications as well as presenting their research at seminars.

Many of the discipline's visitors have also returned on one or more occasions, suggesting that they had found a stimulating and productive research environment as well as a friendly and convivial one. Allen Ivey, James Naylor, Scott Paris, Michael 
Argyle, Melvin Manis, Herbert Lefcourt and Tom Pettigrew all visited the discipline (now school) on appointments as distinguished scholars in psychology supported by an Endowment Fund. This fund was established in the early years of the discipline, following a generous donation from Norman Munn, the author of an early bestselling introductory psychology textbook and a distinguished psychologist who spent many years in the United States before returning to Adelaide.

No record of the development of psychology at Flinders would be complete without reference to the important contribution made by the general staff. Visitors who came to the School of Psychology at Flinders University probably made their first contact with the psychology office. This was a friendly office, with photos of staff, small children, a contrived shot of myself holding a tall poppy, scenes from the annual Christmas picnic by the lake, postcards from overseas, colourful posters, small ornaments - indeed, a whole array of homely things. Carol McNally was the senior secretary in this office for over seventeen years, and one of her colleagues, Joan White, for over eleven years. They, as well as Kay Douglas (née Guest), were long-serving members of our secretarial staff, who gave sterling service to the discipline and school. So, too, did the technical staff, of which the longest-serving member was Leon Snigg. The discipline owes a lot to the efforts of the technical staff in particular, and their contribution is described in more detail in a later section.

In an article that reflected on the early history of psychology at Flinders, I wrote the following assessment:

We have come a long way since the early days. We have turned out graduates who are making a useful contribution to society in various ways as professional psychologists or in many other careers. Some have moved into academic life. We have tried hard to maintain high standards in the academic appointments made to the Discipline (School) and in the quality of our teaching and research. I will not pretend that progress has always been smooth and easy. We have had our fair share of challenges and perturbations but, by and large, we have surmounted them with good grace, due in part to capable and responsible teamwork, open government, planning, consultation, trust, and a mutual respect for the interests and rights of others. (Feather, 1995, p. 25)

I further described my approach to leadership:

For my own part, I have never attempted to be a tribal leader who gathers a pack of disciples committed to a single cause. I respect different points of view that can be ably defended, in the belief that there is virtue in diversity as long as people are not in conflict on the really important issues that affect the School and can work together as a team. I do believe in having clear goals and in working hard to achieve them, both at the individual and group levels. In so doing, I have attempted at Flinders to balance what Freed Bales called the task and maintenance goals of leadership, encouraging people to perform their tasks at the highest possible level while at the same time trying to ensure a friendly and cooperative environment in 
which people can work together for their mutual advantage. That is not always an easy goal to achieve. I am also deeply committed to leading by example in my own teaching, research, and relations with others. But now I am beginning to sound a bit pompous and moralistic and so perhaps it is time to end. (p. 25)

I retired in 2000, but have continued to maintain an active presence in the school via research, attendance at seminars, and social contact with my colleagues.

\section{'Troubles at Flinders' in the 1970s}

\section{Leon Lack}

Professor Feather has explained above how Flinders was to pursue a less traditional university culture with an emphasis on cross-disciplinary collaboration. This impetus to develop a more progressive academic culture, plus the fact of being a new and alternative university to Adelaide, probably tended to attract less traditional students who would consider more radical cultural and political positions. My perspective was that a number of students had taken on more radical political positions through their opposition to conscription and Australia's involvement in the Vietnam War in the late 1960s and early 1970s. They saw Australia's war involvement not only as unjustified but as the result, at least in part, of the Western 'military-industrial complex'. By the mid-1970s, the Whitlam government had withdrawn Australian troops and the Vietnam War issue was all but over. However, it left a more radicalised student body without a cause and may have contributed to the events that followed.

In 1974, a dispute developed in the history discipline between students and staff who wanted to introduce exams for topics that traditionally had been assessed by essays. Despite large student protest demonstrations, the history discipline was adamant about the introduction of exams. One large protest demonstration then migrated to the Registry and virtually occupied the Registry, sending the staff home. The 'occupation of the Registry' continued for several weeks, until students were forced to leave by a cohort of Registry staff and police. In the early days of the 'occupation', a group of Registry and other academic staff tried to challenge the protestors and 'retake' the Registry. Dr David Gibbs, after buying a hamburger for lunch, joined this 'retake' group. However, met by an overwhelming number of pretty fierce-looking students, the 'retake' was unsuccessful and Dr Gibb's hamburger was squashed.

Professor Roger Russell, the vice-chancellor, was overseas and returned home at the news of the occupation. However, the students had a chance to rifle through Professor Russell's filing cabinets to find evidence that much of his earlier neuropsychological research with animals had been funded by the US military. This was enough evidence in their minds to convince them he was a 'lackey' of the US military-industrial complex and deserved to be condemned. They were unaware that most basic research in the US during the cold war in the 1950s and 1960s was funded by the military, 
regardless of its real military value. Nevertheless, it was enough to make Professor Russell and his supporter, Dr Gibbs, a scapegoat for the student protest that had originally started over academic matters.

The Australian Psychological Society came to their defence, as evidenced by this editorial in the Australian Psychologist (1975):

There are three issues which I believe are of importance to Australian psychologists at this moment. Firstly, the February Council of the Society expressed its deep concern with the harassment and terrorist tactics that have been used in an attempt to intimidate two members of this Society; Professor Roger Russell, Vice-Chancellor of the Flinders University of South Australia, and Dr David Gibbs, who is on the staff of the School of Social Sciences at that University. Council resolved to express its concern at the use of threats and violence, the distortion of evidence, the sensational presentation of material and the implication of guilt by association. Council further expressed its belief in freedom of speech, access and assembly and the use of rational arguement $[s i c]$ in discussion. These resolutions were passed unanimously by the February Council and conveyed to the Chancellor of the Flinders University of South Australia, asking him to ensure that the text of the resolutions be conveyed to the members and Council of the Flinders University of South Australia.

The reflection on the Flinders University created by this denial of free expression, concerns psychologists in Australia, not only because two members of our Society are involved, but because such universities can no longer claim any pretensions to be places of 'light, liberty and learning' under such conditions. We regret that this behaviour has taken place and express sympathy to Professor and Mrs. Russell, and Dr Gibbs and his family. We have a sense of revulsion at what this means to the tradition of academic freedom in Australia, and it is encumbent [sic] on us, both as a Society and as individuals, to take initiative in expressing our sentiments when such values are so severely challenged. (pp. 136-7)

This event received considerable news coverage in Adelaide and some coverage interstate, and probably helped to cement Flinders University's early reputation as being the more radical university in South Australia. Forty years has now elapsed, but that reputation probably still lingers to some extent in the minds of older Adelaideans, despite the passing on of virtually all those involved at the time.

\section{Changes in technical services (1970-2016)}

Paul Douglas, development engineer

The psychology technical group was established in the early 1970 s with the appointment of Robyn Fowler as a senior technical officer. He then appointed Leon Snigg from Philips Industries as a technical officer in 1974. The two technical officers were supported by a number of technical assistants, who also administered the Psychology Test Library. The 
technical team initially built numerous electronic apparatus for teaching and research. They also maintained physiological recording equipment (M19) and built interfaces to utilise the Digital PDP 11/55 computers used in the labs. The types of equipment built were quite diverse. For example, the electromyographically [EMG] controlled train set was a hit with students in the 1980s on open days. Also in the 1980s, Robyn Fowler was offered a position at the University of Aberdeen in Scotland, where he re-united with Professor Malcolm Jeeves, for whom he had been a technical officer at the University of Adelaide. With Fowler's farewell, Leon Snigg took over as senior technical officer and Eric Browne from the University of Adelaide was appointed as a technical officer. After a few years, Browne also decided to seek employment in the United Kingdom. His replacement was Gary Sjoberg, who had a strong interest in computing and eventually became psychology's first computing officer.

Personal computers were to replace the PDP 11/55s, and the technical group started building interfaces for the Apple IIs. One of the first tasks the Apple IIE undertook was printing bar graphs from the electronic circuitry that detected Alpha, Delta, Sigma and Theta components for both right and left hemispheres in the Sleep Lab. The electronic circuitry was open architecture and was often referred to as the 'rats' nest'. All the components — such as resistors, capacitors, FETS, ICs and so on - were interconnected to a set of power supply rails (spaced by tag strips), which were taped to the top of a table. The actual circuit was an electronic facsimile of the schematic, which allowed easy access and modification of components as the circuit evolved, in order to achieve the precise analytic function required. This was analogue technology, however, and, despite its functionality, would shortly be replaced by digital technology in psychology research.

In the late 1980s, Tony Cleland, the director of psychology's technical services, decided to expand the technical team, and I was appointed as a technical officer. I came from the aviation world and had recently worked in flight simulation. Combining Leon Snigg's expert knowledge in psychophysiological equipment with my software and digital skills, we started producing our own physiological recording equipment - the first being a precision temperature monitor that measured deep core body and skin temperature, which was recorded by an Apple Computer running National Instruments' LabView. Around this time, Gary Sjoberg moved on to become the faculty computing officer.

Subsequently, Phil Kernick was appointed as his replacement; he completed his honours degree in Computer Science in Artificial Intelligence under Professor David Powers whilst at Flinders. Kernick, Snigg and I computerised the Skinner boxes that were used by psychology in the Animal House located in Biological Sciences. Psychology stopped using the rats' nests and Skinner boxes in the 1990s, with one of Professor Bond's honours students conducting the last study using rats. The Skinner 
boxes and associated equipment were then redeployed to the School of Pharmacology at University of South Australia.

It was decided in the early 1990s to employ a technical officer with a mechanical background, and this led to the appointment of John Murphy, who had over twenty years' experience with the Australian Army. During this period, the technical team consisted of a computing officer, senior technical officer, technical officer (electronic), technical officer (mechanical) and technical assistant (Test Library). The diversity of the team allowed it to provide technical support for the School of Psychology. The offering of the cognitive science program also created new challenges for the technical group. The construction of the new EEG lab, supervised by Dr Richard Clark, was one of the first in the southern hemisphere to be able to perform 128 channels of EEG acquistion, and the lab also used software [FERPS], written by John Altree-Williams and James Tizard, which ran in the three Flinders University EEG labs (School of Medicine, Julia Farr Centre and School of Psychology). This software was replaced with Neuroscan software with the Unix system used for post-analysis. At the same time, the technical team undertook replacing the Sleep Lab Physiological system with an in-house system that met the required biomedical standards. This allowed research type modules to be incorporated, such as a long-term GSR module, which formed part of a $\mathrm{PhD}$ study.

At the turn of the century, computing was becoming a larger component for the technical team. The 'rats' nest' was retired, as its functions could now be carried out digitally with computer programs. The team evolved into the digital world as I started to write cognitive software, having completed a Bachelor of Science (Computing/ Neuroscience) in 2000. The Test Library was taken over by the administration team, leaving a computing officer and two senior technical officers as the technical team. The computing officer has seen a number of appointments since the resignation of Phil Kernick to work at CSIRO in 1995: his successor was Nick Falkner, followed by Chris Harvey, with Jonathan Wheare being appointed in 2000.

There was a steady increase in computer-based tasks and less demand for electronic/mechanical equipment, with John Murphy taking on the role of faculty technical officer, leaving Wheare, Snigg and myself providing technical support for psychology. Wheare provided both software and desktop support, but it became apparent that his skills would be better utilised with the faculty computing group, so he was eventually appointed to a senior role within the faculty group around 2005. This led to the appointment of Steve Butler, who, after a few years' service, was appointed as a system administrator within the Central Server Administration group. The director of technical services, Dr Michael Tlauka, decided after consulting with Butler, Snigg and me that the computing officer role should be redefined. As a result, the faculty computing support would undertake desktop support for psychology, thus allowing psychology to appoint an Information communication technology officer, Ben Maddock, an IT officer from UniSA whose role would be predominately software-related. 
In 2008, Leon Snigg, after thirty-four years' service and a declining need for his high-level electronic engineering skills, also decided it was time to retire. Following Snigg's retirement, a new technical officer and ICT officer positions were advertised and were filled by Dave Hall, a broadcast engineer, and Ben Maddock. As part of a previous review, my own position had also been changed to a development engineer position. Since 2008, the team has seen more emphasis on research using computer-based resources and is continually evolving its skills base to support the research undertaken in psychology with new equipment and software.

Leon Snigg, prior to his appointment in psychology, was a senior electronics engineer at Philips in Adelaide. His skills in designing electronic circuits and building up prototype devices from basic components (for example, resistors, capacitors and so on) were outstanding. He was a wizard in conceptual design and in wielding the soldering iron. For example, the discipline needed a biofeedback device that informed users through tonal pitch of the relative amount of alpha rhythm being produced between the left and right cerebral hemispheres, so that users could bias their performance to left- or right-hemispheric tasks. Snigg created a circuit diagram to carry out such a function and then assembled the circuitry out in the open to easily allow possible alterations. These physical layouts were dubbed 'rats' nests', after their appearance.

\section{Volleyball at Flinders}

Leon Lack

As outlined elsewhere in this book, the University of Adelaide was the birthplace of Australian Rules Volleyball, which continues after an impressive, but puzzlingly long, fifty-two-year history. Some of its players (designated as 'lapsed players' in the ARVB terminology) migrated to Flinders University, where a more civilised volleyball code (using international rules, otherwise known as the 'weak' version) was regularly and enjoyably played in intramural competition. It is clear that when there is competition between teams, an agreed set of rules needs to be used, although this was not a necessity for Adelaide players, who played amongst themselves. Psychology traditionally did well in this Flinders competition, only occasionally losing to biology, and winning the competition in 1986 (see Figures 5.5 and 5.6). Many staff and occasional students played in the weekly games over the 1980s and 1990s, including Dennis Glencross, Jim Crowley, Ian McKee, Paul Douglas, Marika Tiggemann, Leon Lack, Paul Williamson, Geoff Fraser, Loretta Daugalis, Mary Morris, Roxie Orr, Drew Dawson, Peter Ferris, Michael Proeve and Chris Ball. 


\title{
The School of Psychology, Flinders University 1992-96
}

\author{
Nigel Bond
}

The Department of Psychology at Flinders had been reviewed in 1987. The first recommendation was that an experimental psychologist be brought in as professor and head of school. The previous chairs, Professors Leon Mann and Norm Feather, were both social psychologists. The second recommendation was that the department should become a school. The importance of this latter recommendation was that as a school, psychology would have a one-line budget. The name changed but the Faculty of Social Sciences held on to the budget. As it turned out, this was not a problem. The dean, Professor Robin Moore, and the associate dean, John Browett, were both sympathetic and supportive of the school and it gave the school one less thing to do.

I held the view that Flinders was the best school of psychology in South Australia. The University of Adelaide was going through a transition stage and the University of South Australia was still finding its feet. Despite this, the most able students academically still went to Adelaide. I saw it as my task to reverse this.

We began by engaging in a curriculum review. We brought in people from outside of the university, from the profession, and from the other schools in Adelaide. The school offered the bare minimum of psychology to meet accreditation standards, which were then the remit of the Australian Psychological Society. The first change was to unpack the second-year course. While it was divided into four subjects, students had to do all four at the same time (in the interests of integration). This meant that a failure in one could see a student repeat the whole year. The revision of this structural constraint gave us an easy first win with the students.

We also had a numbers problem. Flinders was and still is a relatively small university by Australian standards. I felt that the School of Psychology was the right size and to grow further would not be to the advantage of the school or the university. I suspect that I was the first head of school to ask a vice-chancellor to allow my colleagues and myself to reduce our student intake or at least to be able to control it! With the university keen to maximise student intake, we had been forced to relax quotas on entry to the popular first-year psychology topic. Our numbers had then grown uncontrollably in the Bachelor of Arts and Science degrees. However, that left us with several hundreds of first-year students, with a high percentage of them failing or choosing not to go on in psychology. A lot of the school's resources were devoted to teaching large numbers of students with low aptitude who were unlikely to progress to upper years in psychology.

We then introduced the first four-year Bachelor of Psychology (Honours) program in the country. Given that there was only so much psychology a student could do, we built a series of 'open subjects' into the degree, so that students could pursue a variety 
of experiences, which could inform their subsequent choice of honours directions and career. The degree was important because to enter a master's program in professional psychology, students had to complete an honours program. We were saying to students that if they maintained a certain standard, they were guaranteed a place in honours. Therefore, the intake had to be limited to the number of honours students' thesis projects we could adequately supervise (about forty-five). Because of its attraction and limited intake, the new Bachelor of Psychology (Honours) attracted some 650 first preferences and emerged with a very high Tertiary Education Rank [TER] cut-off of 96.5.

We introduced this new degree just as Flinders moved its medical degree from an undergraduate program to a postgraduate program. The university was concerned that the loss of some 2000 first preferences would reflect badly on it, despite the fact that moving medicine to postgraduate study was a sensible move — one supported by the community at large, and subsequently copied in several other medical schools. The attraction of such a large number of first preferences for the new psychology degree, together with some other new programs, almost completely offset the loss in medicine.

It was also the case that the new degree opened doors to some private schools that had been closed following the 'troubles' at Flinders in the 1970s (see above). Flinders psychology was now attracting some of the best public- and private-school graduates in the state. This fact would eventually become evident to the other psychology schools in the state, which would emulate the model at Flinders, partly as a matter of survival. But by that stage Flinders had re-asserted itself as the premier psychology unit in the state.

Although the Bachelor of Psychology (Honours) degree was immensely successful in gaining us a small cohort of high-achieving high school graduates and provided a highly desirable entry to the prerequisite to a clinical degree program, it needed complementing with another program. It was a very specialist program with little opportunity to pursue other educational interests. It also provided far too few students to maintain our staff numbers. To address these problems, we introduced a Bachelor of Behavioural Science program. This degree would allow students to undertake sufficient study in psychology and a cognate area to enable them to enter honours in either discipline. At the same time, we removed psychology from the Bachelor of Arts and the Bachelor of Science - a move that, in one swoop, removed a large number of less interested and non-continuing students from the first-year course.

The school interacted directly with the rest of the university through its Bachelor of Cognitive Science. This program drew on mathematics, philosophy, neuroscience, and on our own knowledge and skill base. It was a very rigorous program and we were pleased when it was accredited by the APS. I left the school at the end of 1996. Every student who entered psychology in 1997, through the Bachelor of Psychology, Bachelor of Behavioural Sciences and Bachelor of Cognitive Science, had a TER of over 90. We 
called these programs 'niche market' degrees. Their success was then emulated by the rest of the university, which pursued this strategy to great effect for the next fifteen years. Times change, and universities understandably need to respond: recently, the university has decided to move psychology back into the Bachelor of Arts program.

But universities are not just about undergraduate education. The school was committed to supporting its community through its professional programs, namely the Masters in Clinical Psychology and the Masters in Educational Psychology. Both of these programs underwent significant internal change, led by Professor Peter Wilson and Professor Ros Shute, respectively. However, it was difficult to expand the programs because of a lack of placements. This was an issue for all the South Australian universities; indeed, it still is.

Psychology at Flinders also had a significant reputation in research. Professor Mary Luszcz led the work on ageing, together with her colleagues in various other disciplines. Professor Leon Lack was always in the media, given his work on sleep. (Lack knew the value of Altmetrics before they invented the word!) Professor Norm Feather was never without Australian Research Council funding, and published copiously. Importantly, given his eminence, Feather was a frequent and consummate journal reviewer, thereby giving back his knowledge and expertise to the discipline. Professor Richard Clark led the neuroscience laboratory, bringing together static imaging through magnetic resonance imaging and dynamic change through work on event-related brain potentials.

Importantly, the next strengths in research were also being laid at this time. Professor Neil Brewer had begun his work in the area of forensic psychology for which he was to become internationally famous. Likewise, Professor Marika Tiggemann, who had started out working in the area of learned helplessness, began working on women's body image issues. This led to the development of a group working on issues of body image and eating disorders, which is also internationally renowned.

Flinders instituted a series of University Teaching Awards. Four academic staff received such awards: Professor Leon Lack, Professor Neil Brewer, Professor Marika Tiggemann and, most importantly, Dr Mary Morris. Morris's award was special because she became one of only two Level A academics to receive such an award in Australia.

There were many other colleagues who contributed to the life of the school at this time, both academic and administrative. One of my fondest memories of the school was the Monday morning cake club, where a member of staff had to bring in a cake that would be shared by all. Indeed, morning tea was a time to talk, and all were welcome. I have never worked in such a happy environment, before or since. Of course, some good people came and went. The most obvious was Professor John Crawford. Crawford was headhunted back to Aberdeen during one of the Eminence in Research rounds in the UK, but we were lucky to have him for a time. 
Following the arrival of Professor Ian Chubb as vice-chancellor, Professor Russell Linke, who was the deputy vice-chancellor, ran each school and department through a set of indices that would show the performance of the department/school relative to the rest of the university. Psychology and biology were ranked equal first. Flinders has gone from strength to strength since my departure, while at the same time, both Adelaide and the University of South Australia have grown in reputation - a good outcome for all.

\section{School of Psychology, 1997-2001}

\section{Peter Wilson}

I arrived at Flinders to take up my initial position as associate professor and co-ordinator of the clinical psychology program in 1991, coincidentally on the same day on which Professor Nigel Bond was interviewed for the chair of psychology. By the time he resigned in 1996, to move into senior university administration in Sydney, he had left a deep imprint on the school, and positioned psychology to take full advantage of its recognised stature at the university and its prominent standing in the community. Professor Norman Feather, his predecessor and the foundation chair, together with Professor Leon Mann, had fostered the growth of the department, within the School of Social Sciences (later the Faculty of Social and Behavioural Sciences). Psychology at Flinders was fortunate to have had successive heads who advocated a clear sense of direction for the still relatively young department. Their work resulted in the creation of a vibrant research culture, recognised internationally, and a strong sense of academic community.

In the early 1990s, psychology departments throughout Australia were facing a number of challenges: there had been an explosion of new departments and programs during the previous decade, many of which had a strong vocational focus at the undergraduate level; there were new, much tougher accreditation requirements, set by the Australian Psychological Society; there was a surge in demand for psychology as a field of study, both at undergraduate and the postgraduate levels; and there was increased financial pressure on departments to meet the staffing costs and other aspects of their expenditure. The establishment of the Bachelor of Psychology [BPsych] and Bachelor of Behavioural Sciences $[\mathrm{BBSc}]$ degrees was a key step in orienting the discipline towards the new university environment.

A change of leadership in an academic department can be an unsettling time for its members. At the point when I became head, the new flagship BPsych and BBSc degrees had been developed, and the new academic year, with the first intake of students, was imminent. There were several major challenges for the school: to meet the high expectations for quality of education which had been created amongst students; to manage the implementation of the numerous changes to the structure of subjects 
('topics', as they were called at the time); and to assist students in the pathways towards the several different degrees, as the new degrees were phased in and the major in the Bachelor of Arts was being phased out. Dealing with these aspects, while maintaining effective communication within the school, was very much a part of my role.

When I first became head, I was very ably assisted in all these tasks by the school's administrative officer, Ms Lynne Broadbridge, and by Ms Carol McNally, who led the departmental office. It is difficult to imagine performing my role without these two extraordinary people, together with the academic staff, many of whom now occupied new roles as co-ordinators in the undergraduate program — such as Dr Mary Morris (first year), Dr Ed Peay (Honours), Dr Robyn Young (BPsych), Dr Julie Robinson (BBSc) and Dr Richard Clark (BCogSc). I am sure that the number of meetings increased, but I think that a team approach helped to maintain the communication. Some continuation of degree development occurred during my period as head, including the introduction of a Graduate Diploma of Psychology, designed for students who had completed three years of approved study in psychology, and who wished to complete an honours year. This type of fee-paying degree had become very attractive to graduates in other universities, largely as a result of changes to membership requirements of the Australian Psychological Society. In addition, the number of cognate double majors in the BBSc degree was also expanded, enabling psychology to develop links with a larger number of schools within this popular university-wide program.

Psychology at Flinders had a proud history of education in the field of clinical psychology. The Master of Psychology (Clinical) degree had been established in 1972, and had developed under the leadership of Dr John Court, Dr (later Professor) Jack James, and Dr Mike Wood, together with Dr Lia Kapelis, who had remained on the staff. This program was regarded as one of the finest in the country, and I was proud to be appointed to lead and manage its further development. The accreditation standards for clinical psychology had been strengthened quite considerably in the late 1980s. As it happens, I had played a role in that particular development through work within the Psychology Foundation of Australia, together with Professor Syd Lovibond and Professor Barbara Gillam, both then at the University of New South Wales [UNSW]. Professor Lovibond will be well known to many in South Australia, his home state, through his work at the University of Adelaide. One new requirement was for departments to demonstrate their formal connections with the profession, and to ensure a high standard of clinical supervision in field placements, including the assessment of student performance. There were other new requirements for the content of the actual subjects in the degree, including proportions of time that should be devoted to specific areas. Most clinical psychology programs at the time needed to address many of these points, so Flinders was not alone. Undergraduate degrees were also subject to many new requirements. 
On moving to Flinders, I gave priority to ensuring that the clinical program would meet the new requirements as a matter of urgency. In particular, the links with the professional field needed to be strengthened. Following a period in which I visited many of the key placements, and met with field supervisors and officials from the relevant South Australian government departments, I established a Professional Advisory Committee, and called for nominations for membership. I was deeply impressed by the eagerness of this group to be involved in the evolution of the program, despite the monthly Friday afternoon meetings that were a reflection of its prodigious activity. They were also very willing to impose strong requirements for quality assurance in regard to placements, and to establish a program of supervision skills training. I am indebted to this group for the many years of work that we accomplished together as a team. A number of years later, when the university implemented a requirement for such advisory committees, with a different set of processes, I protested that ours was working very well and I did not want to alter it! With assistance from the then vice-chancellor, Professor Anne Edwards, we managed to maintain the system that was in place while meeting the new requirements.

The establishment of links with the field, the SA government and other university departments was a high priority for me, a goal that was greatly strengthened when I became head. The position itself opened doors to the establishment, and provided a strong basis for discussion with people in other leadership roles. In this capacity, I found an academic connection with the University of Adelaide, especially through Christopher Cooper. When financial pressures on departments increased, we began to discuss the idea of a joint clinical psychology program, as a means of sharing the limited resources and therefore improving the quality and the financial viability of both programs. In the end, this fledgling idea did not eventuate, although we did find some areas in which we co-operated more closely to manage short-term staffing gaps.

The disbursement of clinical students amongst the potentially available field placements was a significant problem, initially for both Flinders and Adelaide, but when the University of South Australia also began offering a clinical program, as it clearly needed to do, the pressure increased dramatically. One positive consequence of this challenge was the establishment of a joint committee for the fair and transparent allocation of placements, which brought all three universities together, with a rotating chair. Thus began a new era of collaboration between all three universities, despite initial qualms about how we could manage to cope with the increased numbers of students in the system. Professor Jack Metzer, at the University of South Australia, played a particularly important and constructive role in bringing about this tripartite collaboration.

Other Australian universities had begun to offer doctoral degrees in clinical psychology, or were planning to do so. In particular, many of the newer universities sought to offer a three-year DPsych or PsyD, a common path to clinical psychology 
in the US. At Flinders we wished to maintain the strong focus of the department on research, and therefore sought approval for a combined MPsych/PhD, the first of its kind in Australia which would have a fully integrated program and set of rules related to admission, course transfer, program structure and examination. One novel feature of this new combined degree was the option for students to submit a dissertation in the format of papers, either already submitted, or being prepared, for publication. The long-term consequence of this process was expected to be an increase in the publication rate flowing from research in clinical psychology, further strengthening the department's research performance. There was also an expectation that we would be preparing a new generation of graduates who would take up senior positions and/or become employed in research roles. Building on the strengths of Flinders, we saw this initiative as being consistent with the distinctive niche which psychology at Flinders had occupied within South Australia.

The developments that I have described above occurred over a long period, both before and after I became head of psychology. There was some overlap in my roles of head of department and co-ordinator of the clinical psychology program. After I became head, I maintained both roles for most of my remaining period at Flinders. Dr (later Professor) Rosalyn Shute, who was director of the Educational Psychology program, continued in her role, but very ably and graciously stepped up to assist me in regard to the clinical program, and also assumed the role as director of the clinical program when the need arose. I was fortunate to have a close colleague in John Crawford, with his specialty in clinical neuropsychology, with whom to share the tasks and the many minutiae of the administration of the professional programs. The new bachelor degrees also enhanced the standing of psychology within the university, with a record of attracting applicants from amongst the state's highest school achievers. Psychology was important to the university, and it should also be recorded that the two vice-chancellors during my tenure, Professor Ian Chubb and Professor Anne Edwards, together with the dean of faculty, Dr John Browett, took a great deal of interest in the school and were very attentive to our needs.

Upon taking up the headship in 1997, I relished the opportunity to be more involved in the undergraduate program than I had been at any other stage of my career. I also saw a strong interconnection between the fundamental education and research in the discipline of psychology, and the extension of this scientific foundation, with the research and statistical skills, into various fields of application. I regretted that, in many psychology departments in Australia, there was a schism between the basic discipline and the various fields of professional psychology. Flinders was fortunate to have avoided these problems, largely through the actions of previous heads, and the strong co-operative spirit that characterised the school.

My commitment to this view underpinned my inaugural address after being promoted to professor. In my address I chose to talk about the scientist-practitioner 
model, which epitomises the integrative approach to the education and professional activity of applied psychologists. I should point out that not everyone agrees with the aims of this model, nor with its ability to be implemented in the manner expected by its US pioneers. Within the context of Australian psychology, Adelaide was a hotbed of alternative views on this matter. It was inevitable that, as an outspoken supporter of the scientist-practitioner model, I would become involved in public debates and other activities designed to provide a forum for healthy discussion. In my inaugural professorial lecture at Flinders, speaking to a general university audience, I used examples from the history of astronomy, but in particular, I recall inserting the phrase: 'I would not want to drive over a bridge built by a postmodernist'.

There are many departmental events I remember from my period as head, some of which I would like to highlight here. One of the most satisfying roles of being a head of department is to lead the selection process for new appointments. Both Professor Tracey Wade and Dr Julie Mattiske were appointed during this period, as well as Drs Justine Dandy and Peter Strelan. (I have omitted numerous other people who were appointed on short-term contracts.) It was very satisfying to witness the success of fellow colleagues, through the award of research grants, promotions and teaching awards. At the risk of accidental omission, I can highlight the outstanding research achievements of colleagues such as Professors Mary Luszcz, Neil Brewer, Leon Lack and Richard Clark, all of whom were promoted during this period (and some of whom have been further promoted in the subsequent years). Professor Luszcz also served in an internationally prominent role as the secretary-general of the International Association of Gerontology (1997-2001) and served on the ARC Large Grants Committee during this period. It is also important, when reflecting on the personal success of individuals, to acknowledge the valuable support role played by the technical workshop, which was led by Leon Snigg during my tenure. Much of the research in the school was dependent on the valuable skills of this versatile team.

Naturally, the nature of academic life means that staff members leave to take up positions elsewhere, and so I recall that I made farewell speeches during my headship about very dear colleagues rather more often than I would have liked - first of all about the former head, Nigel Bond, and also about Robert Boeckmann, John Crawford and Mary Morris. Fortunately, research links have been maintained with many former staff members, and such links have further contributed to the school's international standing and to its research output. On the administrative side, Lynne Broadbridge also moved on to higher levels at the University of Adelaide. Some longstanding members of the school, who had made immense contributions over a long period, also retired during this period, including Drs Tony Cleland, Jim Crowley, Ed Peay and Lia Kapelis. In addition, Founding Professor Feather retired from his position in 2000, although he has maintained his very active research activity over many subsequent years. I mention these people in order to put on record the debt that is owed to them for their many years of valuable work on behalf of the school and its students. 
I have fond memories of Flinders psychology as being a very social, or sociable, department. The Monday cake club mentioned earlier by Nigel Bond, the end-of-year picnic and the cricket match were all part of the discipline's culture, as was the somewhat quirky commemoration of the death (or was it birth?) of the Lithuanian violinist, Jascha Heifetz. The common room also played its part in fostering discussions about a wide range of topics. Many departments are not so fortunate in this regard. The school was, in many ways, the right size to foster a sense of community, and there was a comfortable familiarity in working together. These events brought the administrative, technical and academic staff together. There was also rigorous and fruitful debate, which perhaps became possible precisely because of the goodwill and positive feelings within the department, which came from a healthy combination of academic and social activities.

One of the most memorable of these events for me personally was the thirtieth anniversary celebration of the foundation of psychology, which just happened to occur during my tenure, in 1997. And so we celebrated the life of psychology at Flinders with a series of presentations and a social event. Several former staff members presented keynote papers, including Professors Gina Geffen and Leon Mann. Psychology alumni, who now numbered in the many hundreds, were also invited, and we were able to link this event with the establishment of a Psychology Chapter of the Flinders University Alumnus Society.

I think that commemorative activities of this kind, including this book itself, which celebrates the history of psychology in South Australia more broadly, are very important occasions in academic life. These commemorations provide a link between our present day and the past, and help to explain the evolution of our institutions. They provide an opportunity to reflect on the achievements of each of our academic institutions, and of individuals within them. Universities are, in essence, the people who collectively constitute them, rather than the bricks and mortar from which they are built. Psychology at Flinders has occupied a distinctive position within the state, and the documentation of its unique fifty-year history is an important step in its official chronicle.

\section{Migration between the universities}

Leon Lack

Although this book has presented the histories of the three South Australian university psychology departments separately, there has been a fair amount of cross-fertilisation between the three schools. Student graduates from one have frequently taken staff positions at another, and some staff have migrated from one to another. Generally, the most migration seems to have been from an older university to a newer one that was still in in its early period and growing. For example, in the lists below it can be 
seen that the most movement has been from Adelaide to Flinders when Flinders was growing rapidly in the 1970s and 1980s. The next-largest wave of migration was in the 1990s and 2000s from Flinders to UniSA, as its school was becoming established.

Adelaide to Flinders:

Richard Clark

David Gibbs

Denis Glencross

Leon Lack

Frank Ledwith

John Court

Neil Brewer

Marika Tiggemann

Robyn Young

Tracey Wade

Mike Nicholls (via Melbourne University)

Flinders to Adelaide:

Carolyn Semmler

Peter Strelan

Flinders to UniSA:

Drew Dawson

Kurt Lushington

Janet Bryan

Robert Ranzijn

Owen Churches

Mark Kohler (via Women's and Children's Hospital)

Siobhan Banks (via University of Pennsylvania)

Michelle Short

Hannah Keage

Tobias Loetscher

Michelle Tuckey

Michael Proeve 


\section{UniSA to Flinders:}

Owen Churches

Adelaide to UniSA:

Tony Winefield

Jack Metzer

Maureen Dollard

Carla Litchfield

John Court (via Flinders, Tabor College)

UniSA to Adelaide:

Phil Mohr

Michael Proeve

Change of academic life (1970-2016)

\section{Leon Lack}

While the historical listing of the academic personnel and programs is essential, it needs to be supplemented by accounts of the dramatic changes to academic and student life and the nature of university education over this history, particularly over the last thirty years. These changes were driven by changes in our culture as a whole and, indeed, have been experienced in virtually all institutions throughout modern society. They have occurred in many different areas of academic life, such as in personal communication, teaching, research production, and conditions of everyday life at the university.

The impact of technological changes over the last thirty years (desktop and portable computers, mobile phones, text messaging, wi-fi, email, social networking, and so on) has been dramatic on the university experience, not only for academics but also for students and for the nature of university education. Virtually all of our lectures are now video-recorded and available to students online. This can have advantages for students who cannot make it to a lecture or who want to review the lectures for increased understanding and consolidation of information. However, the day-to-day observations of academic staff suggest that an increasing number of students now do not attend the lectures (around 70-90 per cent), despite academics' attempts to halt this trend by improving the interest and student interactions in lectures, and despite the university's attempts to avoid all lecture conflicts and increase parking availability with the use of computer-driven university-wide timetabling. This decline in attendance has occurred despite preliminary unpublished evidence in psychology at Flinders that 
those who attend lectures may obtain almost a complete grade higher in final marks for the topic. This does not necessarily suggest that lecture attendance will produce higher grades: that is a question needing a randomised control trial.

Technological changes have impacted our manner of teaching as well. There is good evidence that requiring students to utilise their visual imagination (as earlier teaching methods did) rather than supplying students with the visual stimulus (through, for example, animated power point presentations and films) is more effective for their long-term memory. Peter Delin's (1969) illustration of the effectiveness of mnemonic devices utilising mental imagery supports this finding. Therefore, although the new technology may have some advantages, it can detract from effective learning if not used prudently and sparingly.

Research endeavour has also changed immensely over this period. Simpler statistics were once favoured ( $\mathrm{t}$-tests, non-parametric correlations, sign tests, Mann-Whitneys) because calculations for more complex stats (Pearson correlations, ANOVAs) had to be done by hand or on simple arithmetic mechanical and then digital calculators. The first pocket calculators became available in the late 1960s (HP, Texas Instruments, Commodore) but were very expensive $(\$ 200-\$ 500)$. Some of the later versions of the pocket calculators became 'programmable'; with little magnetic strips, users could input some stats functions (Pearson correlations) that would automatically calculate ' $r$ ' after inputting the raw data. Some calculators (Commodore 64) were hardwired with these functions and did not require magnetic strips. However, with the advent and increasing availability of mainframe computers in the late 1960s and early 1970s, larger data sets and somewhat more complex statistics could be attempted.

'Attempt' is the operative word. An IBM punch card would have to be punched for every data line in the data file and a stack of punch cards containing the Fortran program to carry out one specific stats test would have to be obtained or punched out. The stack for the program and the one for the data would be combined, secured with tight rubber bands, and transported (hopefully without dropping the stack or having it fall apart) to the computer centre for analysis. A day or two later, the user would get their card stack back and hopefully the printed output of the results of the analysis of that one test. Commonly, there would be an error in the data or program, completely nullifying the user's efforts - and another attempt, and therefore delay, was necessary.

Today, after inputting the data, a simple click of the mouse on a desktop computer, which in itself is more powerful and faster than the building-occupying mainframe computers of the 1970s and even into the 1980s, will carry out some of the most sophisticated statistical analyses. However, many users do not fully understand or correctly interpret such analyses. On occasion, I have cringed when a student fails to look at the descriptive stats, jumps straight to the 'p' value and gleefully announces that it is significant but fails to recognise that the results have gone in the direction opposite to the hypothesis. 
The process of publishing studies also now takes much less time. The turnaround time today takes weeks compared with the many months it took in the 1960s through to the 1980s. Technological changes, too, have enabled all manner of quantification of research productivity and impact. Our curriculum vitae now include, for each publication, the impact factor of the journal and the number of citations made to the publication. An academic's overall impact can be measured by the h-index and instantly obtained online. Because of its apparent objectivity and ready availability, it is alluring to use the h-index in making relative comparisons between academics. However, the magnitude of the h-index must be interpreted with caution when comparing between fields or between different research areas within psychology.

Lastly, I must mention some of the changes to the social and cultural environments of universities over the last thirty years which present challenges to the quality of academic endeavour. Past heads of psychology at Flinders have all commented on the encouraging and positive atmosphere at Flinders during their tenure. As the longest-employed member of the school, I would say that this positive environment has been maintained across our entire history. Nevertheless, we have not been immune from these more global cultural changes. Over the last few decades, the academic lifestyle has changed significantly: there is less face-to-face socialising amongst academic staff members, and the reason given by staff for this is that they feel they simply do not have the time, as there is too much work to be done. Academic life has become more frenetic with less time and opportunity for reflective thought, critical analysis and creativity. Technological changes have dramatically sped up and increased the amount and variety of communication (much of it from administrative levels in the university). This increased 'busy' work is inevitably at the expense of time that academics have to consider communications that are directly relevant to, and more likely to advance, our academic field. Technological changes and administrative pressure to fully engage with the technology has accelerated the academic 'rat race'.

But even as rats in a maze learning task are capable of jumping out of an uncovered maze and running in a beeline directly to the goal box, we, also, should be capable of using our cognitive maps and dealing creatively with current and future working environments, as long as we keep our most important goal at the forefront of our attention - that is, academic endeavour, and the teaching, research, and community involvement/applications of the highest intellectual and creative quality which this endeavour requires.

It is perhaps appropriate to complete this section with a view of Flinders University today captured not by an aerial photograph (the small drones could not get the right angle) but with the use of technology from Google Earth. Vegetation now adorns the place. Come and visit in person. The Social Sciences North Building, home for psychology, is the large rectangular building with the white roof in the upper left area. 
Further up the North Ridge are now the Social Sciences South, Law and Commerce, and Education Buildings. Under construction in this scene are the new plaza and student Hub.

\section{References}

Atkinson, JW, \& Feather, NT (Eds.). (1966). A theory of achievement motivation. New York: Wiley.

Cronbach, LJ. (1957). The two disciplines of scientific psychology. American Psychologist, 12, 671-684.

Delin, PS. (1969). An experimental study of mnemonic devices in verbal learning (unpublished doctoral dissertation, University of Adelaide, Australia).

Editorial. (1975). Australian Psychologist, 10, 136-137.

Feather, NT. (1975). Values in education and society. New York: Free Press.

Feather, NT (Ed.). (1982). Expectations and actions: Expectancy-value models in psychology. Hillsdale, NJ: Erlbaum.

Feather, NT. (1990). The psychological impact of unemployment. New York: Springer-Verlag.

Feather, NT. (1995). Psychology at Flinders University: Some reflections on the first 28 years. Bulletin of the Australian Psychological Society, 17, 21-25.

Feather, NT. (1999). Values, achievement, and justice: Studies in the psychology of deservingness. New York: Kluwer Academic/Plenum Publishers.

Janis, IL, \& Mann, L. (1977). Decision making: A psychological analysis of conflict, choice, and commitment. New York: Free Press.

Mann, L. (1969). Social psychology. Sydney: Wiley.

O'Brien, G. (1986). Psychology of work and unemployment. New York: Wiley. 



\title{
Recent history of Flinders School of Psychology
}

\author{
Edited by Tracey Wade, \\ with assistance from those named in the relevant sections below.
}

\section{Brief history}

Flinders University was established in 1966, and in 1967 teaching of psychology to first-year students commenced, along with the appointment of the foundational chair, Professor Norm Feather. The School (and former Discipline) of Psychology has always been located in the Faculty (formerly School) of Social Sciences. The faculty, renamed the Faculty of Behavioural and Social Sciences from 1 January 2010, includes three other schools (Business, International Studies, and Social and Policy Studies). A snapshot of the historical timeline for the school is presented in Figure 6.1.

Over the last fifteen years, research interests in the school have been united by a cohesive theme: the rigorous application of theory and methodological approaches from basic psychology through to a range of applied issues of relevance to human behaviour across the lifespan: clinical and health, developmental, social, neuroscience and psychophysiology, memory and cognition. Psychological science is a designated area of research strength within Flinders University. Current staff in the school and their respective research interests are shown in Table 6.1.

\section{Research strengths over the last fifteen years}

This chapter presents information about the recent research history of the school since 2000. In particular, we highlight the main themes of our externally funded research and its impact. 


\section{The Eyewitness Memory Laboratory Neil Brewer and Nathan Weber}

The Eyewitness Memory Laboratory was established in the late 1990s by Neil Brewer, and he and former PhD student and current colleague, Nathan Weber, now manage the lab. It has received continuous ARC funding from the late 1990s through to 2019. This funding has included six ARC Discovery Projects led by Neil Brewer and one led by Nathan Weber; one ARC Linkage International Social Science International; and one ARC-LIEF grant, with total funding of around \$2.5 million. Neil Brewer and Nathan Weber have also been involved as chief investigators on eyewitness memory projects funded by the ARC, ESRC (UK), NSF (US) and the British Academy, with funding well in excess of $\$ 1$ million.

Although there has been a diverse array of projects conducted in the lab, the major focus has been in the area of eyewitness identification. The study of eyewitness identification is important because eyewitnesses frequently make mistakes when presented with a line-up. You can get a sense that such mistakes are not rare events by visiting the Innocence Project (2016) and seeing just how prevalent erroneous identifications are in wrongful convictions.

Our research has involved both lab and field studies, typically involving witnesses viewing a mock-crime or some other witnessed event, followed at some later stage by the presentation of a police line-up or photo-array. One major contribution has been to demonstrate the relationships between eyewitness confidence and accuracy. A 2001 survey of eyewitness memory experts in the American Psychologist (Kassin, Tubb, Hosch, \& Memon, 2001) asserted that eyewitness confidence was not a useful indicator of memorial accuracy. Since then, we have published a series of papers in flagship journals of the American Psychological Association and the Association for Psychological Science which have overturned this view, providing a new landscape on the confidence-accuracy relationship, one which is widely acknowledged in a special US National Academy of Sciences report (National Research Council, 2014).

A second significant contribution - and one which has secured the international reputation of the Flinders lab as one of the truly innovative centres of eyewitness memory research in the world - has been the development of novel identification procedures that avoid the requirement for witnesses to make a decision at the line-up, a decision which they often have great difficulty making. Our procedures exploit the pattern of witness confidence judgments assigned to different line-up members to determine if the culprit is present in a line-up, and thus far this approach is proving to be superior to the traditional line-up procedure.

A third major contribution has been Nathan Weber's development and application of advanced statistical procedures which have transformed the way data from these types of experiments have been analysed and interpreted. 
Over the journey, fifteen PhD students have graduated from the eyewitness lab, many of whom moved on to postdoctoral positions and tenured academic appointments elsewhere in Australia and overseas. Neil Brewer and Nathan Weber have held editorial positions on the boards of the major international psychology-law journals and Neil Brewer has served as editor-in-chief of the American Psychological Association's Journal of Experimental Psychology: Applied for 2013-17, the first Australian to be appointed as an APA journal chief editor.

Importantly, research from this laboratory has had a significantly broad community impact. Neil Brewer is regularly invited by professional associations of judges, magistrates, police and lawyers to provide plenaries and workshops on eyewitness evidence. His advice has also shaped new police operational procedures and legislation around the issue of eyewitness identification. The research has been cited in various judgments in US Courts and in amicus briefs for courts in the US, and has featured in such outlets as Catalyst, The Economist, the Wall Street Journal, Time and Radio National's Law Report.

\section{Food cravings}

\section{Eva Kemps and Marika Tiggemann}

Our research focuses on the underlying cognitive processes of food cravings with a view to developing effective interventions to curb such cravings and reduce unwanted consumption. A food craving is an intense desire or urge to eat a specific food, usually chocolate, cake, ice cream or pizza. Although most people experience occasional food cravings without any problem, cravings can be problematic for some people and even pose health risks. In particular, unwanted consumption triggered by food cravings can produce feelings of guilt and shame. Food cravings can also trigger binge-eating episodes, which in turn can lead to the development of disordered eating and obesity. These negative consequences of food cravings necessitate the development of effective interventions to manage and control such cravings. This need is further exacerbated by the abundance of food and eating cues in our environment. People are continually exposed to food and images of food in shops, fast food outlets and through advertising on television, magazines, public transport and billboards. Such exposure is particularly problematic for at-risk populations, such as restrained eaters and overweight individuals.

While most previous work has sought to identify the antecedents and consequences of food cravings, our research focuses specifically on the actual craving experience itself. We argue that by better understanding the mechanisms that underpin this experience we can identify specific targets for intervention. Using a combination of survey and experimental methodology, we identified two cognitive processes that govern the food craving experience: (i) mental imagery and (ii) attentional bias (Kemps \& Tiggemann, 2009; Tiggemann \& Kemps, 2005). With regard to the first 
cognitive process, mental imagery, we found that when people have a food craving, they report having vivid images of the desired food, including how delicious it looks and how good it smells and tastes. In terms of the second process, attentional bias, we showed that during a food-craving episode, people's attention is automatically captured by cues of the desired food in the environment.

Thus our subsequent investigations sought to target these two cognitive processes with a view to reducing the frequency and intensity of food cravings as well as consumption. In a series of experimental designs, we have shown that interfering with the cognitive processes that support desire-related food imagery reduced the strength of the experienced craving (Kemps \& Tiggemann, 2007; Kemps, Tiggemann, \& Bettany, 2012; Kemps, Tiggemann, Woods, \& Soekov, 2004). Specifically, by asking people to imagine a series of everyday sights (for example, a rainbow) or smells (for example, eucalyptus) while they have a food craving, they reported less intense cravings for the food. Having people engage in a simple visual task, such as watching a flickering pattern of black-and-white dots, or sniffing a non-food odorant such as jasmine, similarly reduced the intensity of their food cravings, as well as the likelihood of consuming the craved food. This is thought to occur because the interference task takes up limited cognitive resources that are needed to generate and maintain the image of the desired food, and thereby reduces the vividness of that image, and consequently the strength of the craving.

In a parallel series of studies, we have shown that experimentally manipulating people's attention for craved food cues can also reduce their food cravings and food intake (Kemps, Tiggemann, Orr, \& Grear, 2014). Specifically, by training people to redirect their attention away from craved food cues, they showed a reduced attentional bias for such cues. Importantly, they also reported less intense food cravings and ate less of the craved food in a subsequent laboratory-based taste test.

Our research demonstrates the clinical utility of applying cognitive experimental methods to a current and pressing health issue. Tasks that target the underlying imagery and attentional processes of food cravings clearly hold promise as interventions for reducing such cravings and consumption. They could serve as effective in-the-moment tools to curb the craving right there and then, and thus prevent subsequent unwanted consumption. In so doing, they could provide useful adjuncts within the context of treatments for problem eating behaviour. From a practical perspective, imagery-based and attentional tasks could easily be deployed on computerised hand-held devices, such as smart phones and tablets, and could thus be used virtually anytime and anywhere.

This body of research has to date produced around forty scientific publications. It has also had real-world impact. In 2013, our findings were taken up by Primitive Response Technology, who developed CraveMate, an iPhone app designed to manage food cravings and change unhealthy eating habits (To end food craving, 2013). More 
generally, over the past decade our food craving work has received widespread media coverage in newspapers, magazines, radio and online.

\section{Sleep}

\section{Leon Lack and Michael Gradisar}

Since 1999, I and my colleagues have obtained six ARC and six NHMRC large Category 1 research grants worth over $\$ 4$ million all in the circadian rhythm, sleep and insomnia area. A careful laboratory experiment, conducted by Professor Kurt Lushington, now professor at UniSA, confirmed that the afternoon sleepy period ('post-lunch' dip) was not due to lunch but a feature of the endogenous circadian (twenty-four-hour) body clock (Lack \& Lushington, 1996). The good news is that this sleepiness can be overcome with a brief 'power' nap of no more than ten minutes of sleep. Shorter or longer sleeps did not have such good recuperation results. Longer sleeps produced some lethargy for a while following the nap, known as sleep inertia (Brooks \& Lack, 2006). The recuperative power of the brief nap could not be explained by existent theories of sleep and, therefore, stimulated our new theory of sleep (Process 'O' for onset of sleep or waking) to explain the napping benefits, as well as the ability to extend sleep towards the end of the sleep period after a brief awakening. Dr Nicole Lovato also conducted a study that showed how brief naps can be useful in a simulated night-shift work situation (Lovato, Lack, Ferguson, \& Tremaine, 2009). Therefore, not only did we provide the scientific confirmation of the benefits of power naps (Want to boost your memory and mood?, 2013) but also the research led to a new theory of sleep processes.

Our earlier work, pioneered by Drew Dawson, now professor and director of the Appleton Institute, CQU, showed the role of a mistimed body clock in certain types of insomnia and also showed that bright light stimulation could retime the body clock (Morris, Lack, \& Dawson, 1990; Dawson, Lack, \& Morris, 1993). However, bright light therapy devices were large, cumbersome and expensive. The serendipitous discovery of my daughter's failure to turn off her flashing light-emitting diode [LED] bicycle light after several days of operation interested us in their use in small portable light therapy devices. Several years later, after extensive research (conducted by Dr Helen Wright), we were the first to show that it was the blue- and blue/green-coloured LEDs that were effective in changing body clock timing. Patents were obtained and a commercial device (Re-timer.com, see Figure 6.2 is now available for effecting body clock mistiming treatments (for example, body clock sleep disorders, jet lag, shift-work and winter depression).

Since body clock mistiming is seen as the basis of body clock sleeping difficulties, these difficulties should be corrected with retiming the body clock. Although our research has shown that bright light and melatonin can be used effectively for this treatment, 
relapse is often rapid and thus we have been studying other basic abnormalities in the body clocks of these patients. We have shown just recently that the body clocks of those with delayed sleep problems have body clocks that naturally tick over more slowly than normal, which would give then a constantly stronger tendency to delay their sleep patterns in the twenty-four-hour world (Micic, Lovato, Gradisar, Burgess, Ferguson, \& Lack, 2016). These patients also have personality characteristics and behavioural habits that make it difficult to keep time with the earth's rotation (Micic, Lovato, Gradisar, \& Lack, 2016). Therefore, the treatment of these individuals will require not only the retiming effects of morning bright light and evening melatonin but also cognitive/behavioural therapy to address the complex causes of their difficulties.

It has been known for a considerable time that those suffering insomnia typically underestimate their objective total sleep time and that this contributes to their anxiety about their sleep and fuels their insomnia. This stimulated our exploration of the judgments of being awake or having been asleep with the use of carefully controlled laboratory testing. The research, carried out by Dr Jeremy Mercer, now director of Clinical Services at the Adelaide Institute for Sleep Health, showed that those with insomnia have considerable difficulty perceiving an awakening from sleep across the night and judge it to be just a continuation of wakefulness, thus overestimating the amount of wakeful time across the night (Mercer, Bootzin, \& Lack, 2002). The research also showed that with feedback they could improve their perception of awakenings from sleep, and that this improved their sleep, thus reducing their insomnia. This discovery has led to improvements in the treatment of insomnia with the use of feedback from objective sleep recording.

Our earlier laboratory studies showing how acute sleep deprivation in normal participants rapidly sent them to sleep suggested it might be a useful treatment for insomnia. A new randomised control trial of this sleep-deprivation-based treatment, allowing dozens of rapid sleep onsets over a twenty-four-hour trial, showed it to be as effective as the best presently available behavioural treatments, and — combined with those treatments - even better benefits were shown (Harris, Lack, Kemp, Wright, \& Bootzin, 2012). We are now exploring ways to translate these findings into the home environment to make sleep deprivation treatment more accessible and less expensive to patients. This will involve an iPhone application that can accurately detect sleep onset.

Combining our insomnia research with decades of clinical experience has led to another practical insomnia treatment administered to groups of patients over only four brief sessions. This treatment has shown considerable benefits for the sleep and daytime functioning of older insomnia patients (Lovato, Lack, Wright, \& Kennaway, 2014) as well as people with co-morbid insomnia and obstructive sleep apnoea [OSA]. Our aim is to improve the sleep in these co-morbid patients before the introduction of positive airway pressure treatment for their OSA and thus more successfully treat these very impaired. 
Yet it is not only adults whom we have found to suffer from sleep disorders. Further research is being carried out by Drs Michelle Short, Hayley Dohnt and Michael Gradisar into insomnia in adolescents. In one of the largest surveys of teenagers' sleep, using sleep diaries and 'FitBit-like' wrist monitors, we found that one in every three Australian adolescents has difficulty falling asleep on school nights, with nearly 10 per cent (around three teens per classroom) qualifying for an Insomnia Disorder (Dohnt, Gradisar \& Short, 2012). Research from the US suggests that this difficulty falling asleep may be due to a delay in the timing of circadian rhythms and/or a reduced ability to build up sleep pressure as teens get older. Our latest ARC-funded research will now tease out whether it is a weakening sleep pressure and/or a delaying circadian rhythm that causes this sleep difficulty, when we invite a group of fifty children aged ten into the sleep lab to measure these biological processes every six months for the next few years — wish us luck!

\section{Life span development and ageing}

Mary Luszcz

In 1979, I arrived at Flinders University as a lecturer in life span developmental psychology, strongly influenced by the then novel theoretical approach of Paul Baltes (1987). I had trained in experimental cognitive development, with an initial focus on memory in intellectually disabled individuals and children (Luszcz \& Bacharach, 1975), but by the time I left Canada my research had shifted to the upper end of life, examining ageing (Luszcz \& Fitzgerald, 1986). Parallels ran through work which was geared to understanding memory abilities spared in those with intellectual challenges, then to understanding how memory and language developed, and subsequently to how memory faltered as ageing ensued. Initial ARC-funded research used experimental methods to understand recall and recognition of words and prose in older adults (Luszcz, Roberts, \& Mattiske, 1990). With students, I also explored secondary ageing in older adults with memory impairment (Bird \& Luszcz, 1991). A strong inclination to grasp 'normal' cognitive development and ageing (Luszcz, Bryan, \& Kent, 1997) served me well when I became involved in a multidisciplinary population-based longitudinal panel study of older adults. The Australian Longitudinal Study of Ageing [ALSA] (Luszcz et al., 2014) became my abiding research enterprise for the next twenty-three years (see Figure 6.3).

Even as an undergraduate I was drawn to longitudinal methods. In Yellow Springs, Ohio, the Fels Research Institute was conducting a longitudinal study of child development with which I became intrigued. The opportunity to pursue development in older adults brought to fruition my dream of implementing longitudinal methods to better understand ageing. It also brought a more expansive research agenda and approach to my interest in how context influenced behaviour and development, by 
adding to individual differences, historical, social, biomedical and societal influences on various outcomes (Anstey, Hofer, \& Luszcz, 2003).

Having moved my research agenda beyond simply cognitive domains, I pursued attitudinal, intergenerational and affective dimensions of ageing and mortality. Experimental methods gave way to multiple regression, path-analysis and methods modelling latent growth curves, dual change scores and dyadic development in couples. Small subsamples of ALSA participants contributed valuable insight into sleep, widowhood and resilience (Browne-Yung, Walker, \& Luszcz, 2015) through qualitative studies. ALSA is unique in incorporating multidimensional survey interviews with behavioural, neuropsychological and anthropometric measurements at the population level. Its stature is evidenced by inclusion in several research consortia designed to coalesce multiple longitudinal studies to more powerfully assess relationships to, and mechanisms of, ageing. It has provided fertile ground for the work of higher-degree students, post-doctoral fellows and colleagues around the world. I do not claim sole responsibility or repute from the ALSA; it has been a collaborative effort from the start and, for many years, Professor Kaarin Anstey and Dr Tim Windsor have been central to its success. With studies of children as young as two years old and adults up to 108 years of age, my research has truly spanned development across life. Visit the Flinders Centre of Ageing Studies website (http://www.flinders.edu.au/sabs/fcas) to explore our findings.

\section{Asymmetries}

Mike Nicholls

All vertebrates have a clearly defined top and bottom. In the case of terrestrial vertebrates, the bottom is usually characterised by feet of some sort. Similarly, the front and backs of vertebrates are easy to distinguish, with the front usually being defined by a head or face. The one dimension that appears symmetrical, and which is so often confused, is the lateral (left-right) axis. Left-right symmetry most likely evolved because the natural (non-human) world is essentially symmetrical. That is, food or predators are equally likely to appear on the left or right — so it would not make much sense for an organism to evolve where its sensory or motor systems were biased toward one side.

Despite the apparent symmetry of vertebrates, there are striking functional asymmetries between the left and right cerebral hemispheres - especially in humans. These asymmetries, which give rise to numerous asymmetries in behaviour, are the main interest of the Brain and Cognition Laboratory. While most people are aware of the preference someone might show for one hand or the other, they are generally unaware of the asymmetries that affect their ability to hear, see, touch and move. These asymmetries can have a profound effect on our ability to interact effectively with our 
environment, and can affect everything from the cheek a person turns when posing for a photo to the side of the door they might bump into. The research in the Brain and Cognition Laboratory investigates the nature of the asymmetries that occur in a world that is so nearly symmetrical with a particular view as to their function and why they may have evolved.

Research funded in recent years has focused on spatial asymmetries in attention. Damage to the right hemisphere, especially the parietal regions, can result in a disorder known as spatial neglect. This disorder causes individuals to over-attend to their right side and to neglect the left.

While many people are aware of the extreme rightward bias that occurs in neglect, fewer are aware of the leftward attentional bias that occurs in normally functioning individuals. This bias, also known as pseudoneglect, causes people to bisect lines slightly to the right of their true centre. Our current research programme aims to uncover the cognitive and neurological mechanisms that underlie pseudoneglect.

Pseudoneglect can be indexed with the greyscales task. An example of the task is shown in Figure 6.4. When asked to indicate which image appears darker overall, participants will typically pick the stimulus that is darker on the left side, irrespective of whether it is on the top or bottom. Normal participants show a robust preference of approximately 65 per cent for the leftward stimulus. In contrast, neglect patients show an extreme bias in the opposite direction and will pick the stimulus that is dark on the right over 90 per cent of the time. Even when patients with right parietal damage have recovered and show no obvious sign of neglect for cancellation and line bisection tasks, a rightward bias is found for the greyscales task.

More recently, we have become interested in how these attentional biases affect everyday behaviour. As one example, we have investigated how asymmetries in attention affect how a person kicks a ball between two goal posts. We first examined this bias in the laboratory and asked participants to kick a soccer ball between two goal posts. Relative to a baseline condition, we found that people deviated to the right of true centre. This rightward bias is consistent with the effects of pseudoneglect in far (out-of-reach) space, where a rightward deviation from centre is expected. We then investigated whether this bias could be found in the field. To do this, we sampled all Australian Football League games played from 2005 to 2009. We reasoned that players, when kicking at goal, should aim for the middle between the two goal posts. However, due to the effects of pseudoneglect in far space, the perceived middle should be shifted slightly to the right of true centre. Therefore, when players miss, they are more likely to miss to the right and score a rightward behind. Consistent with this prediction, we found that more rightward behinds were scored relative to leftward behinds.

As another example of the applied outcomes of our research, we have investigated how people navigate through an aperture. Our initial research showed that, when 
walking through a narrow doorway, people were more likely to bump to the right. While this rightward bumping could be due to the effect of attentional asymmetries, it could also be the result of something like foot or leg dominance - which causes a person to veer in one direction. To address this issue, we carried out further research using electric wheelchairs. Over a series of experiments we found a rightward bias, which was consistent across different doorway widths and different types of vehicle (for example, a motorised scooter), and which even occurred when the wheelchair was operated via remote control. Our most recent research has further demonstrated that rightward deviations occur for the operation of miniaturised (toy) remote-control vehicles. The research has implications for the control of machinery where fine judgements of position are required.

\section{Trauma and memory}

\section{Reg Nixon}

Since arriving at Flinders in late 2002, I have continued researching the area of post-traumatic stress disorder [PTSD]. These endeavours have included both applied research, in an effort to better improve our treatments for PTSD, as well as more basic research, with a particular focus on understanding cognitive processes - in particular, memory, and its relationship to adaptive and maladaptive trauma adjustment.

Memory in trauma is an interesting phenomenon. On the one hand, traumatic experiences that result in PTSD appear to be indelible events and are described as life-changing by sufferers, never to be forgotten and sometimes re-experienced, unwillingly, in excruciating detail. On the other hand, sufferers at times report difficulties in comprehensively and accurately recalling details of the event. On occasions, this difficulty exacerbates their distress, as they wonder why they cannot remember everything and they ruminate over the implications of not recalling aspects of this negative event. The trauma field itself has differing views about memory and its role in PTSD. For example, this has included a period of substantial division, as heated debates raged around the issue of whether or not trauma could be forgotten (or repressed/suppressed, depending on one's theoretical orientation). It is in this context - helped by Australian Research Council funding (amongst other sources of funding), and with the assistance of students over the years - that I have tried to answer some of the questions that trauma and memory throw up.

Practical and ethical issues understandably make it a challenging exercise to study memory for trauma in a rigorous fashion. This has called for naturalistic research at times. Testing people's memory for threatening information prior to, and just after, embarking on their first skydive was informative. Somewhat mimicking the levels of arousal that occur during a traumatic event, jumping out of a plane at 10000 feet, it seems, can influence how well you remember important versus not so important information! 
My lab has also specialised in using the now infamous 'trauma video' to study the mechanics of trauma memory. Although fictional, this somewhat gruesome video clip has allowed us to better understand what happens when people try to avoid or suppress their memory of something unpleasant. While suppression frequently replicates the classic rebound effect (where the suppression results in even more intrusions than if the person had allowed themselves to think of the film), we have also documented that it results in improved memory for the very information that people are trying hard to suppress and forget. This is particularly useful information to impart to our PTSD clients, who frequently use suppression as an ineffective means of controlling their intrusive memories. We have observed that this suppression is problematic regardless of whether it occurs during the negative event or afterwards. Although we have not (yet) combined watching a trauma video in a plane before skydiving, we have used hyperventilation in the laboratory setting to study hyperarousal and memory processes. Thus we have seen that hyperarousal while watching a trauma film strengthens encoding of information. Consequently, this results in greater accessibility to aspects of emotional memory and promotes subsequent intrusive experiences. Although an infrequent occurrence, we have also found that trauma film + hyperventilation + sensitivity to images of blood = fainting. Thus we have over the years fine-tuned our informed consent procedures for research participants.

We also study children's memory for unpleasant and negative events. We have found that, in contrast to some theories of traumatic memory, children can be quite accurate in their recollection of events, whether it be the circumstances surrounding a significant car accident, details of the medical treatment received in the hospital, or even the details of care procedures such as the removal of pins that were used to assist healing fractures. What is particularly interesting is that while we do not observe post-traumatic stress symptoms to heavily influence children's accuracy when reporting on these events, their perception of the quality of their memory is different. Relative to children showing good adjustment, children with PTSD symptoms think their memory is not particularly good.

\section{How we remember and misremember traumatic experiences}

Melanie Takarangi

I joined the School of Psychology at Flinders University in mid-2011, after completing my doctoral work in New Zealand followed by a lectureship in the UK. My lab the Forensic and Clinical Cognition Laboratory - uses experimental paradigms and theory from clinical psychology and cognitive science to understand real-life situations in which memory distortion can be maladaptive. For example, our memories are crucial to determining outcomes in clinical and legal settings, including the reliability of testimony, and psychological wellbeing. Currently, much of my lab's research focuses 
on autobiographical memory for negative and traumatic experiences and, specifically, the mechanisms underlying traumatic memory distortion.

People's memories for traumatic events are - like their memories for more mundane events - easily distorted. Dr Deryn Strange and I — along with our students - are working to address how and why we misremember trauma. We have developed a paradigm that reliably demonstrates memory distortion for an analogue trauma in the lab. In this approach, people watch an emotional film of a fatal car accident. The film appears as a series of short segments with brief black buffers between segments; the twist is that some critical aspects of the film are missing: those critical scenes are either traumatic (a child screaming for her parents) or non-traumatic (the arrival of the rescue helicopter). The next day, we ask people what segments they really saw (we call these 'old' scenes); segments they never saw and do not fit in the film ('new' scenes); and the crucial segments that we removed ('missing' scenes). Do people 'fill in the gaps' of their memory, ultimately telling us that they remember seeing scenes from the film they never actually saw? And, if they do, what kinds of scenes are they more likely to falsely remember? Most people would expect that people would be highly unlikely to falsely remember additional traumatic scenes. But our hypothesis - that memory distortion might lead to PTSD — rests on the idea that traumatic footage is actually the kind of information that people would be most likely to falsely remember.

This has turned out to be the case. We have found that people falsely remembered seeing 26 per cent of the missing scenes, or an additional 13.5 seconds ( 7 per cent) more of the event than they actually did see (Strange \& Takarangi, 2012). Moreover, people were more likely to falsely remember the more traumatic scenes than they were the less traumatic scenes. We also found that people who reported getting 'flashes' of memory — seeing a scene from the film 'replaying' in their mind — reported more false memories. This finding is consistent with data from studies assessing trauma exposure reports over time: real victims of personal trauma often come to report being exposed to traumatic events they did not initially report experiencing, a phenomenon known as 'memory amplification'. Importantly, memory amplification carries real consequences: the more amplification people demonstrate, the more likely they are to report the 're-experiencing' symptoms associated with PTSD, such as intrusive thoughts and images.

More recently, we have turned to the question of how to explain memory amplification. We propose that the mechanism could be a failure in people's source monitoring [SM]. I am currently funded by the ARC (2014-16), in collaboration with Professor Reg Nixon and Dr Deryn Strange, to examine this proposal. According to the Source Monitoring Framework, people do not store the details of their experiences in memory with labels specifying the detail origins. Instead, people rely on heuristics, such as how familiar event details feel, to determine whether a remembered detail actually occurred or was merely suggested or imagined. However, such heuristics can 
lead to memory distortion. Interestingly, traumatic events might be more susceptible to SM errors than benign events because they typically provide more avenues for mental imagery, which can make source monitoring more difficult. For example, people often rehearse traumatic experiences internally via intrusive images, thoughts and memories. These intrusions may act as a springboard for other imagined thoughts and images related to the event, such as plausible extensions of the event, which could provide one source of inaccurate details about the event. Also, traumatic events are often rehearsed extensively in response to external information: victims may make a statement to police, be exposed to media footage of similar events, and engage in conversations with other friends, family, doctors or therapists. Each rehearsal opportunity is a potential source of inaccurate details. Critically, over time, such details may become just as familiar as genuine memory traces, increasing the likelihood of SM errors.

We have used our memory 'gaps' paradigm to show that manipulations designed to affect people's source monitoring ability lead people to exhibit more (or less) memory distortion (Strange \& Takarangi, 2015). In later studies using photographs as an analogue for trauma, we have examined internal (for example, imagined details) and external (for example, misleading details received after the traumatic event) factors. Akin to the field data, we have found that people who have more analogue symptoms in response to traumatic photographs are also more likely to remember additional photographs over time (Oulton, Takarangi, \& Strange, 2016). This effect is particularly strong among 'memory amplifiers', people who misremember seeing additional photographs later, compared with what they remembered initially.

A second set of experiments demonstrates that memory amplification may also manifest as misremembering proximity to trauma. Here, the extent to which people re-experienced traumatic aspects of the photographs was associated with misremembering the photographs as having narrower boundaries, or being 'closer' to the events depicted (known as 'boundary restriction'; Takarangi, Oulton, Green, \& Strange, 2016). Taken together, these findings suggest that intrusions about an analogue trauma are associated with remembering that trauma experience as worse over time. Finally, we have found that people incorporate false event details from external sources into their memory for analogue trauma: here, people were more likely to misremember seeing photographs when they read descriptions of those photographs, compared with when the photographs were completely novel. It is likely that the descriptions led people to imagine unseen photographs, which increased SM difficulty. We are continuing to investigate the role of generating plausible extensions to intrusions, on amplification.

Four other lines of work are central to my research program. First, problems with memory also emerge among victims of sexual assault, whose memories are often impaired by alcohol consumption. Here, in collaboration with Dr Heather Flowe, we have focused on how alcohol affects memory for probative details about the offense (for example, Flowe, Takarangi, Humphries, \& Wright, 2016), and on the relationship 
between distressing memories and psychological adjustment. Second, I have examined the degree to which people can accurately monitor their memories when they are experiencing intrusive thoughts about a trauma, and the factors that affect monitoring performance (Takarangi, Strange, \& Lindsay, 2014). Third, in collaboration with Dr Nicole Thomas, I am examining the proposal from neuroimaging studies that PTSD may have a 'neural signature', predominantly characterised by abnormalities within the temporal and parietal lobes of the right hemisphere. Our behavioural experiments investigate whether the right hemisphere plays a specialised role in processing, and remembering, trauma. Finally, I am interested in memory biases that underlie aggression and violent thinking and behaviour (for example, Laney $\&$ Takarangi, 2013; Takarangi, Polaschek, Hignett, \& Garry, 2008). My research has shown that aggressive people show a bias to remember both true and false aggressive information, including their own involvement in past aggressive incidents.

Taken together, my research program adds to theoretical models of PTSD, alcohol and memory, and aggressive cognition. At an applied level, my findings contribute to the management of distorted and intrusive trauma memories; the development of police protocols for interviewing intoxicated victims; and interventions with chronically aggressive individuals. These issues are particularly important given the high personal and societal costs of PTSD, alcohol misuse and interpersonal violence.

\section{Body image}

\section{Marika Tiggemann}

After I arrived at Flinders as a junior academic (with little in the way of resources), I needed to have a long, hard think about what I might really be interested in. I came up with the answer 'something to do with women and bodies and eating', which coalesced into 'body image', and I have been conducting research in this area, broadly defined, since the mid-1990s. This was well before body image became the contemporary concern that it is today, and my thinking has evolved markedly over time.

At its simplest, body image refers to our perceptions, thoughts, feelings and any resultant behaviours towards our bodies. Unfortunately, for many women and girls, and increasingly for men and boys, body image is experienced negatively. Such body dissatisfaction has itself been associated with serious negative consequences, including excessive dieting or exercise, low self-esteem, and the emergence of clinical eating disorders.

Most of my work is informed by a sociocultural perspective, in which current high levels of body dissatisfaction and disordered eating in Western societies are attributed to rigid and unrealistic societal standards of beauty. For women, the current ideal is young, tall, toned and inordinately thin. For men, the ideal is a muscular ' $v$ '-shape, with a well-developed upper body but narrow hips and flat stomach. These ideals are 
transmitted and reinforced through a number of psychosocial influences, including family, peers and the mass media. And although the ideals are impossible for most people to achieve by healthy means, they are nevertheless internalised, with the result that most people, in comparing themselves with these internalised ideals, fall far short.

Within this general framework, there are several major strands to my research. These include body image across the lifespan, the stigmatisation of fat, the consequences of dieting, the objectification of women and the sexualisation of girlhood. But I have been particularly interested in the role of the mass media as the most pervasive purveyor of sociocultural ideals. We have used several different methodologies to research this question. For example, focus groups of adolescent girls have reported that looking at thin models in the fashion magazines makes them feel bad about their own bodies; our cross-sectional research has shown that reading fashion magazines is related to body dissatisfaction and disordered eating; and our experimental research has demonstrated that acute exposure to thin ideal fashion images results in decreased mood and body esteem for women, mediated by upward social comparison processing.

We have extended demonstrations of these phenomena to girls as young as six years of age, and to middle-aged and older women, as well as to adolescent and adult men. An earlier ARC-funded research project (2000-03) entitled 'The role of television-watching in the construction of adolescent body image and disturbed eating' produced some of the first evidence that the watching of particular television programs, especially soap operas and music videos, was likewise related to negative body image (Tiggemann \& Pickering, 1996). More particularly, Facebook use by both adolescent and pre-adolescent girls was associated with body image concerns and disordered eating behaviours (Tiggemann \& Slater, 2013, 2014). Given the rapidly increasing use of social media, these findings have potentially serious implications.

My current ARC-funded research project (2015-18), entitled '"Warning: This image has been digitally altered": The effect of disclaimer labels on women's mood and body dissatisfaction', investigates the effectiveness of adding disclaimer labels to digitally altered fashion magazine images. This is a strategy that has been recommended in Australia (National Advisory Group on Body Image, 2009) and suggested or adopted in a number of countries internationally (France, Israel, Great Britain). The underlying rationale is that informing readers that the images have been digitally altered will remind them that the images are unrealistic and therefore not appropriate to compare themselves with, and hence body image should be preserved. Although this sounds reasonable, as yet there is little evidence to support the effectiveness of such a strategy. In fact, our early data (self-report and eye-tracking) indicate that such labels may make women pay more attention to the model's body than they otherwise would and this, for some women, leads to greater, rather than lower, body dissatisfaction. Clearly, research is urgently required in order to offer sensible advice to policy makers and governments. 
Finally, my newest interest is in the construct of positive body image. This refers to respect, love and acceptance of one's body. Importantly, it is conceptualised as more than just the absence of negative body image and has been associated with positive attributes beyond body image, such as optimism and wellbeing. My students and I have conducted a series of studies investigating predictors of positive body image, with a view to identifying possible points of intervention for enriching people's lives in this way. Thus far we have identified (cross-sectionally only at this stage) that participation in a variety of embodying activities such as yoga and belly dance, as well as individual variables like self-compassion, may be associated with positive body image.

\section{Eating disorders}

Tracey Wade

When I was undertaking my Masters of Clinical Psychology at the Australian National University, I started treating women who had eating disorders. I continued this work at University of Cambridge with Professor Peter Cooper and Dr Sián Coker, where I was inspired to return to university so that $\mathrm{I}$ could conduct $\mathrm{PhD}$ research into the aetiology of eating disorders. I did this research at Flinders University under the supervision of Professors Nick Martin and Marika Tiggemann and Suzanne Abraham, examining the genetic epidemiology of eating disorders. This involves using structural equation modelling with twin data, to examine the relative contributions of genetic and environmental (unique and shared) influences on the development of disordered eating. My findings were at the forefront of studies that took a more sophisticated analytical approach to twin data (see Figure 6.6). Since that time, dozens of twin studies have been conducted in the area.

In essence this type of research answers the question: 'Why do eating disorders run in families?' In the nineteenth century, Charcot (1868) described the families of people with eating disorders as pernicious influences and Gull (Acland, 1894) said that they were the worst attendants. This was the start of a long-held belief that families caused eating disorders, a belief that only started to be challenged when the new generation of twin studies came along, finding that there was a clear and substantial contribution of genes to the development of disordered eating, with very little evidence of shared (familial) environment.

Since that time my work has continued to make a substantial contribution to furthering understanding of eating disorders, both across aetiology, prevention and treatment. Since starting work at Flinders in December 1999, I have been funded as a chief investigator on five different National Health and Medical Research Council grants, totalling \$1 816 239. These grants have funded genetic epidemiology work, including the collection of three waves of data with adolescent female twins as they were growing up (Wade, Byrne, \& Bryant-Waugh, 2008; Wilksch \& Wade, 2009; 
Wilksch \& Wade, 2010; Wade et al., 2013; Fairweather-Schmidt \& Wade, 2014; Wade \& O'Shea, 2015; Fairweather-Schmidt \& Wade, 2015; Fairweather-Schmidt \& Wade, 2016); a prevention study for eating disorders (where Dr Simon Wilksch was the first chief investigator); and a treatment study for anorexia nervosa (with Associate Professor Sue Byrne as the first chief investigator) (Andony et al., 2015). This latter study will inform the development of new clinical guidelines for the treatment of anorexia nervosa currently being revised in the United Kingdom. I have supervised seven PhD students in the area of eating disorders, with another six currently working with me. I also have an interest in the prevention and treatment of perfectionism, a risk factor for eating disorders and other mental illnesses, with a book on the treatment of perfectionism published with Guilford in 2014 (Egan, Wade, Shafran, \& Antony, 2014).

This work has translational value, as I have been involved in the improvement of, prevention, and treatment of eating disorders at both the federal and the state level in Australia. I am a member of the steering committee of the National Eating Disorder Collaboration, and also a member of the management committee of the Statewide Eating Disorder Services, of which I am also the academic lead. These clinical services are committed to ongoing evaluation of their work with a view to modifying services offered in response to the data, and the clinical work also generates important research questions to answer - a perfect example, I hope, of the scientist-practitioner model in practice!

\section{Justice}

\section{Michael Wenzel}

While the psychology of justice has long been a research focus at Flinders University, in particular with the contributions by Norm Feather, psychology's foundation chair, to the concept of deservingness (for example, Feather, 1999), my arrival in 2005 has since added an emphasis on justice restoration. Before joining Flinders, I had spent several years at the Australian National University researching justice and 'responsive regulation' in taxation, and working closely with Valerie and John Braithwaite, whose signature research is on restorative justice. I became inevitably intrigued by this concept, too; and so I came to Flinders with a large ARC grant (in collaboration with Norm Feather and Michael Platow) which enabled me to focus on the question: 'How do we seek justice after hurt, offence or terror? Retributive and restorative responses'. I managed to attract a highly talented post-doctoral researcher to the project, Tyler Okimoto, who had just finished his PhD at New York University under the supervision of Tom Tyler. Even following the end of the project, with Tyler moving on to Yale and then the University of Queensland, we have continued our immensely rewarding and productive research collaboration and developed further our justice restoration theory (as it has been coined) (Wenzel, Okimoto, Feather, \& Platow, 2008). 
Our research proposes a distinction between retributive and restorative justice as two different notions of repairing justice following a wrongdoing: that is, respectively, justice repair through the imposition of punishment on the offender versus the restoration of consensus about violated values. Preferences for retributive or restorative justice depend on the symbolic implications that are attributed to the wrongdoing: an offender may be seen as illegitimately appropriating status and power, and/or as questioning what are presumed to be shared values. Our framework helps to illuminate the psychological functions of punishment — for example, in restoring status/power - and of restorative dialogue — for example, in reaffirming values and shared identities. Justice restoration theory allows for an innovative analysis of a whole range of responses to wrongdoing (Okimoto \& Wenzel, 2008), including offender apology and victim forgiveness.

From the perspective of justice restoration theory, the psychology of forgiveness can be understood afresh, as I proposed in research funded by a subsequent ARC Discovery grant. While forgiveness is commonly understood and researched as a sentiment (non-retributive, non-avoidant and benevolent) toward the offender — one that derives most proximately from empathy — we can also understand forgiveness as a decision and an act that can bring about changes in sentiments, such as empathy. A victim's act of forgiveness can address the symbolic implications attributed to the transgression. It can elevate the victim's status and power by providing a sense of moral superiority and control over the situation, and it can imply the expectation and hope that the offender does, despite the wrongdoing, share the same values. As a consequence, while forgiveness is traditionally portrayed as the antithesis of justice that is, as a gift that requires the victim to sacrifice justice - it can instead, in line with justice restoration theory, promote a victim's feelings of justice (Wenzel \& Okimoto, 2010, 2012).

Conversely, in the literature it has also been argued that the repair of justice can promote forgiveness, including justice repair through punishing the offender (for example, Worthington, 2006). However, we found that while both punishment and restorative dialogue restore feelings of justice, it is only when they are restored through restorative means (not retributive means) that justice is positively related to forgiveness (Wenzel \& Okimoto, 2014). Thus, if forgiveness sacrifices anything, it is retribution, rather than the restoration of justice. Conversely, engagement in retributive justice can sacrifice forgiveness, while restorative justice may promote forgiveness.

Similar processes also apply to intergroup transgressions and relations between victim and offender groups. Our research found that an ingroup's collective decision to forgive the offending group (that is, the outgroup) led to greater feelings of status/ power and greater perceived value consensus between the groups. Through these feelings, the decision led to greater feelings of justice, less hostile emotions and more positive feelings towards the outgroup (Wenzel \& Okimoto, 2015). 
Given the positive implications of forgiveness for justice and reconciliation, an important question is what factors may promote forgiving responses in intergroup relations. In a current ARC Discovery project I, together with Tyler Okimoto and Matthew Hornsey, investigate the effect of apologies on forgiveness. Earlier research suggested that, contrary to their commonly beneficial effects in interpersonal contexts, apologies in intergroup situations have little benefit for forgiveness (for example, Philpot \& Hornsey, 2008). The question is why. Public and political apologies, including those between groups, have seen a stark increase in recent decades. The fact that we are living in a so-called age of apology can itself have paradoxical effects, as our research has shown - on the one hand increasing the expectation and demand for an apology, and on the other hand devaluing its meaning and sincerity and thus limiting its effect on forgiveness (Okimoto, Wenzel, \& Hornsey, 2015).

Indeed, scepticism about the sincerity of intergroup apologies might be particularly rife when these are offered by individual leaders, whereas grassroots apologies that emerge through a groundswell of citizen action and social media are more effective, as we found (Okimoto, Hornsey, \& Wenzel, 2016). Indeed, one key challenge for intergroup apologies, which are naturally expressed by individuals on behalf of the group, is the possible perception that the apology is not representative of the views in the wider offender group. In other words, we argue, and have found through our research, that the sincerity of an apology takes on a whole different meaning in intergroup contexts: more important than conveying the speaker's genuine emotions is that the apology reflects the sentiment in the wider group. Intergroup apologies that fail to do so are perceived as less sincere and are hence less effective in eliciting forgiveness (Wenzel, Okimoto, Hornsey, Lawrence-Wood, \& Coughlin, 2016). A further complication of transgressions by members of one group against another is that appraisals of the situation as intergroup or interpersonal are in themselves subject to divergence between the groups. We have found that offender groups are more likely to attribute the wrongdoing to an individual, whereas victim groups tend to see the offender group, as a whole, responsible (Hornsey, Okimoto, \& Wenzel, in press). Victims may thus demand a collective apology that offender groups are less willing to provide. Thus the offender perspective to wrongdoing is equally crucial as the victims' perspective in what is essentially an interactive process of moral repair.

In interpersonal contexts, I have also been studying, with Lydia Woodyatt (in her PhD work and beyond), offender responses to wrongdoing, shame and guilt. Our studies have shown that individual offenders tend to react defensively by downplaying the wrongdoing and their guilt, in particular when their sense of belonging is threatened, or when they feel ostracised or rejected (Woodyatt \& Wenzel, 2013a). Clearly, the ability of offenders to forgive themselves has benefits for their own wellbeing and self-esteem, but the critical question is how genuine self-forgiveness can be understood conceptually and promoted practically, without this meaning that offenders let themselves off the hook. 
We argue that, rather than downplaying their guilt, genuine self-forgiveness means severance of the link between acceptance of responsibility and negative self-evaluation (Wenzel, Woodyatt, \& Hedrick, 2012). Woodyatt and I developed a differentiated process scale that distinguishes genuine self-forgiveness from pseudo self-forgiveness; we found evidence that genuine self-forgiveness helps offenders to restore not only their selves but also their relationships (Woodyatt \& Wenzel, 2013b). Key to genuine self-forgiveness seems to be a process of value affirmation, where offenders reaffirm their commitment to the violated values and the centrality of the violated values to their self (Woodyatt \& Wenzel, 2014). Justice restoration and, more broadly, moral repair in interpersonal and intergroup relations are complex and intriguing processes, and Flinders researchers have made significant contributions to their understanding.

\section{Other relevant research}

Dr Michelle Arnold

PhD, MSc (University of Victoria, Canada), BA (with Distinction, University of Lethbridge, Canada)

- My current research interests include the reconstructive nature of memory (for example, source monitoring, illusory recollection), judgments of remembering and forgetting, the strategic regulation of accuracy (in test-taking situations, own-race bias, and so on), and how the experimental paradigms and memory questions we employ influence participants' performance (for example, remember/know vs recollection/familiarity ratings).

Dr Mariette Berndsen

BSc, $M A, P h D$ (Amsterdam)

- My research interest focuses on emotions and in particular on the following: emotions occurring specifically in the Australian context; experience of emotions on behalf of one's ingroup; when does taking the perspective of an outgroup member reduce negative emotions and attitudes towards the outgroup? I'm also interested in the role of trust. For example, which aspects of trust (such as competence, integrity) are important in a particular situation? Another research interest involves respect: what are the consequences of perceived (lack of) respect for oneself and for people whom one feels close to?

Professor Neil Brewer

BA (Hons), PhD (Adelaide), FASSA

- $\quad$ See above. 
Dr Junwen Chen

$B A, M A, P h D$ (Waseda, Japan)

- My research interests focus on developing and evaluating intervention techniques for anxiety disorders. I have been involved in a range of clinical studies aimed at developing and examining the effectiveness of treatment (techniques) for social anxiety (disorder) and worry, as well as the factors pertaining to these disorders and behaviours. In addition to anxiety disorders, cross-cultural study is another focus of my study. I have been involved in several cross-cultural studies on investigating the underlying cognitive and behavioural constructs associated with social anxiety (disorder). Currently, I am primarily conducting research projects on cognitive processing in social anxiety and interventions for excessive worry as well as cross-cultural comparison of social anxiety.

Mr Geoff Fraser

BSc, BA, MA (Tasmania)

- My current research interests include the effect of coping strategies and achievement goals on academic achievement, and the relationships between Facebook use, social comparison and mood.

Associate Professor Michael Gradisar

BSc (Hons), MPsych (Clin), PhD (Flinders)

- $\quad$ See above.

Professor Eva Kemps

BPsych, BEd, MPsych, PhD (Ghent, Belgium)

- See above.

Professor Leon Lack

$B A$ (Stanford), PhD (Adelaide)

- See above.

Professor Mary Luszcz

BA (Dayton), Magna Cum Lauda: Psi Chi, Phi Beta Kappa; MA (George Peabody); PhD (Alabama), FASSA, FGSA, FAPS, AAGF

- $\quad$ See above.

Dr Robert Lynd-Stevenson

$B A$ (Hons) (Western Australia), PhD (Clinical) (ANU)

- My research interests include an examination of the role of social factors in the aetiology and treatment of psychopathology, and the contribution of cognitions in generating anxiety and depression, as well as the role of a 
clinical psychologist as defined by scientific method. I am also interested in understanding the principles and practice of causal analysis in scientific psychology.

Dr Julie Mattiske

$B A$ (Hons), PhD (Flinders)

- My teaching and research interests include abnormal psychology, human memory function, women's health, and methodological issues, particularly in relation to research into interventions.

Professor Jason McCarley

PhD (Experimental Psychology, University of Louisville), MA (Experimental Psychology, University of Louisville), BA (Psychology, Purdue University)

- My research interests include applied and basic aspects of perception, attention and cognition.

Professor Mike Nicholls

BArchSt, BA (Hons), PhD (Cantab)

- See above.

Professor Reg Nixon

BA (Hons), MPsych (Clinical), PhD (Sydney)

- See above.

Dr Julie Robinson

BA (Hons) (Newcastle), MA (University of North Carolina-Chapel Hill, US), PhD (Newcastle)

- My research focuses on development and adaptation in contexts of adversity.

My current research focuses on two populations: child and adolescent refugees and migrants, and patients with a life-limiting illness.

Dr Melanie Takarangi

BA, BSc (Hons), PhD (VUW, New Zealand)

- See above.

Professor Marika Tiggemann

$B A, P h D$ (Adelaide)

- See above.

Dr Michael Tlauka

BSc (Hons), PhD (University of Leicester)

- My research primarily focuses on human spatial memory. I am interested in both theoretical and applied (Human Factors) issues. Recent research projects 
include an investigation into whether spatial memory is modality-specific, people's ability to learn spatial information from maps, navigation through virtual environments, and gender differences in spatial ability.

Professor Tracey Wade

BSc (Adelaide), Hons (Flinders), MClinPsych (ANU), PhD (Flinders)

- See above.

Dr Nathan Weber

BSc (Hons), PhD (Flinders)

- See above.

Associate Professor Michael Wenzel

Dipl Psych, PhD (Münster, Germany)

- See above.

Dr Paul Williamson

BSc (Hons), Dip App Stat, PhD (Flinders)

- My main research interest is in how individuals make uncertainty and confidence judgments. I am particularly interested in metacognition, source monitoring and social influence processes within the misinformation effect (and memory conformity/social contagion).

Dr Tim Windsor

$B A$ Hons (UNE), PhD (UNE)

- See above.

Dr Lydia Woodyatt

BMin, Grad Dip Psych, BA (Hons), PhD

- My research focus on self-forgiveness, offender rehabilitation, processing shame and guilt, justice, leadership, motivation and prosocial behaviour. I am also broadly interested in the intersection between social and clinical psychology, especially in areas related to coping.

Professor Robyn Young

BA (Hons), Grad Dip Psych Prac, PhD (Adelaide)

- Together with colleagues at Flinders University, I have developed a screening tool that will identify autistic characteristics in children as young as twelve months of age. This tool, the Autism Detection in Early Childhood $[\mathrm{ADEC}]$ is now being published through the Australian Council of Educational Research [ACER]. Research teams in Mexico, China, US, Malaysia and Sweden are also investigating its use. This research has led to the development of an Early Intervention Research Program [EIRP] based at 
Flinders University. The EIRP uses behaviour analysis techniques to provide an intensive, individualised intervention program. The activities developed in this program have led to the development of SPECTRA, a behavioural intervention package published by ACER. Other interests include savant syndrome, diagnostic issues surrounding Asperger syndrome and childhood trauma.

\section{References}

Acland, TD. (1894). A collection of published writings of WW Gull. London: New Sydenham Society.

Andony, L, Tay, L, Allen, KL, Wade, TD, Hay, P, Touyz, S ... \& Byrne SM. (2015). Therapist adherence in the Strong Without Anorexia Nervosa (SWAN) study: A randomised controlled trial of three treatments for adults with anorexia nervosa. International Journal of Eating Disorders, 48, 1170-1175.

Anstey, K, Hofer, SM, \& Luszcz, MA. (2003). Cross-sectional and longitudinal patterns of dedifferentiation in late-life cognitive and sensory function: The effects of age, ability, attrition and occasion of measurement. Journal of Experimental Psychology: General, 132, 470-487.

Baltes, PB. (1987). Theoretical propositions of life-span developmental psychology: On the dynamics between growth and decline. Developmental Psychology, 23, 611-626.

Bird, M, \& Luszcz, MA. (1991). Encoding specificity, depth of processing and cued recall in Alzheimer's Disease. Journal of Clinical and Experimental Neuropsychology, 13, 508-520.

Brooks, A, \& Lack, L. (2006). A brief afternoon nap following nocturnal sleep restriction: Which nap duration is most recuperative? Sleep, 29(6), 831-840.

Browne-Yung, K, Walker, RB, \& Luszcz, MA. (2015). An examination of resilience and coping in the oldest old using life narrative method. The Gerontologist. Advance online publication. DOI: $10.1093 /$ geront/gnv137.

Charcot, JM. (1868). Histologie de la sclérose en plaques [Histology of multiple sclerosis]. Gazette des hopitaux, Paris, 41, 554-555.

Dawson, D, Lack, L, \& Morris, M. (1993). Phase resetting of the human circadian pacemaker with use of a single pulse of bright light. Chronobiol Int, 10(2), 94-102.

Dohnt, H, Gradisar, M, \& Short, MA. Insomnia and its symptoms in adolescents: Comparing DSM-IV and ICSD-II diagnostic criteria. Journal of Clinical Sleep Medicine, 8(3), 295-299.

Egan, SJ, Wade, TD, Shafran, R, \& Antony, M. (2014). Cognitive-behavioural treatment of perfectionism. New York: Guilford.

Fairweather-Schmidt, AK, \& Wade, TD. (2014). DSM-5 eating disorders and other specified eating and feeding disorders: Is there a meaningful differentiation? International Journal of Eating Disorders, 47, 524-533.

Fairweather-Schmidt, AK, \& Wade, TD. (2015). Changes in genetic and environmental influences on disordered eating between early and late adolescence: A longitudinal twin study. Psychological Medicine, 45, 3249-3258. 
Fairweather-Schmidt, AK, \& Wade, TD. (2016). Characterizing and predicting trajectories of disordered eating over adolescence. Journal of Abnormal Psychology, 125, 369-380.

Feather, N. (1999). Judgments of deservingness: Studies in the psychology of justice and achievement. Personality and Social Psychology Review, 3, 86-107.

Flowe, HD, Takarangi, MKT, Humphries, JE, \& Wright, DS. (2016). Alcohol and remembering a hypothetical sexual assault: Can people who were under the influence of alcohol during the event provide accurate testimony? Memory, 24(8). DOI: $10.1080 / 09658211.2015 .1064536$.

Harris, J, Lack, L, Kemp, K, Wright, H, \& Bootzin, R. (2012). A randomized controlled trial of intensive sleep retraining (ISR): A brief conditioning treatment for chronic insomnia. Sleep, 35(1), 49-60.

Hornsey, MJ, Okimoto, TG, \& Wenzel, M. (In press). The appraisal gap: Why victim and transgressor groups disagree on the need for a collective apology. European Journal of Social Psychology.

Innocence project. (n.d.). Retrieved from http://www.innocenceproject.org.

Kassin, SM, Tubb, VA, Hosch, HM, \& Memon, A. (2001). On the 'general acceptance' of eyewitness testimony research: A new survey of the experts. American Psychologist, 56, 405-416.

Kemps, E, \& Tiggemann, M. (2007). Modality-specific imagery reduces cravings for food: An application of the Elaborated Intrusion Theory of Desire to food craving. Journal of Experimental Psychology: Applied, 13, 95-104.

Kemps, E, \& Tiggemann, M. (2009). Attentional bias for craving-related (chocolate) food cues. Experimental and Clinical Psychopharmacology, 17, 425-433.

Kemps, E, Tiggemann, M, \& Bettany, S. (2012). Non-food odorants reduce chocolate cravings. Appetite, 58, 1087-1090.

Kemps, E, Tiggemann, M, Orr, J, \& Grear, J. (2014). Attentional re-training can reduce chocolate consumption. Journal of Experimental Psychology: Applied, 20, 94-102.

Kemps, E, Tiggemann, M, Woods, D, \& Soekov, B. (2004). Reduction of food cravings through visuo-spatial processing. International Journal of Eating Disorders, 36, 31-40.

Lack, LC, \& Lushington, K. (1996). The rhythms of human sleep propensity and core body temperature. Journal of Sleep Research, 5(1), 1-11.

Laney, C, \& Takarangi, MKT. (2013). False memories for involvement in aggression. Acta Psychologica, 143, 227-234.

Lovato, N, Lack, L, Ferguson, S, Tremaine, R. (2009). The effects of a 30 minute nap during night shift following a prophylactic sleep in the afternoon. Sleep and Biological Rhythms, 7, 34-42.

Lovato, N, Lack, L, Wright, H, \& Kennaway, DJ. (2014). Evaluation of a brief treatment program of cognitive behavior therapy for insomnia in older adults. Sleep, 37(1), 117-126.

Luszcz, MA, \& Bacharach, VR. (1975). List organization and rehearsal instructions in recognition memory of retarded adults. American Journal of Mental Deficiency, 80, 57-62.

Luszcz, MA, Bryan, J, \& Kent, P. (1997). Predicting episodic memory performance of very old men and women: Contributions from age, depression, activity, cognitive ability and speed. Psychology and Aging, 12, 340-351. 
Luszcz, MA, \& Fitzgerald, K. (1986). Understanding cohort differences in cross-generational, self and peer perceptions. Journal of Gerontology, 41, 234-240.

Luszcz, MA, Giles, LC, Anstey, KJ, Browne-Yung, K, Walker, RB, \& Windsor, TD. (2014). Cohort profile: The Australian Longitudinal Study of Ageing (ALSA). International Journal of Epidemiology. Advance online publication. DOI: 10.1093/ije/dyu196.

Luszcz, MA, Roberts, T, \& Mattiske, J. (1990). Use of relational and individual item information in remembering by older and younger adults. Psychology and Aging, 5, 242-249.

Mercer, JD, Bootzin, RR, \& Lack, LC. (2002). Insomniacs' perception of wake instead of sleep. Sleep, 25(5), 564-571.

Micic, G, Lovato, N, Gradisar, M, Burgess, HJ, Ferguson, SA, \& Lack, L. (2016). Circadian melatonin and temperature taus in delayed sleep-wake phase disorder and non-24-hour sleep-wake rhythm disorder patients: An Ultradian constant routine study. Journal of Biological Rhythms, 31(4), 387-405.

Micic G, Lovato, N, Gradisar, M, \& Lack, L. (2016). Personality differences in Delayed Sleep-Wake Phase Disorder and Non-24-Hour Sleep-Wake Rhythm Disorder patients relative to healthy sleepers. Sleep Medicine. DOI: 10.1016/j.sleep.2016.04.002.

Morris, M, Lack, L, \& Dawson, D. (1990). Sleep-onset insomniacs have delayed temperature rhythms. Sleep, 13(1), 1-14.

National Advisory Group on Body Image. (2009). Voluntary Industry Code of Conduct on Body Image. Retrieved from http://apo.org.au/node/21888.

National Research Council. (2014). Identifying the culprit: Assessing eyewitness identification. Washington, DC: The National Academies Press.

Okimoto, TG, Hornsey, MJ, \& Wenzel, M. (2016). The power of grassroots gestures of remorse for promoting intergroup forgiveness. Manuscript submitted for publication.

Okimoto, TG, \& Wenzel, M. (2008). The symbolic meaning of transgressions: Towards a unifying framework of justice restoration. In K Hegtvedt, \& J Clay-Warner (Eds.), Advances in group processes (pp. 291-326). Bingley, UK: Emerald.

Okimoto, TG, Wenzel, M, \& Hornsey, MJ. (2015). Apologies demanded yet devalued: Normative dilution in the age of apology. Journal of Experimental Social Psychology, 60, 133-136.

Oulton, JM, Takarangi, MKT, \& Strange, D. (2016). Memory amplification for trauma: Investigating the role of analogue PTSD symptoms in the laboratory. Journal of Anxiety Disorders, 42, 60-70. DOI: 10.1016/j.janxdis.2016.06.001.

Philpot, CR, \& Hornsey, MJ. (2008). What happens when groups say sorry: The effect of intergroup apologies on their recipients. Personality and Social Psychology Bulletin, 34, 474-487.

Strange, D, \& Takarangi, MKT. (2012). False memories for missing aspects of traumatic events. Acta Psychologica, 141, 322-386.

Strange, D, \& Takarangi, MKT. (2015). Investigating the variability of memory distortion for an analogue trauma. Memory, 23, 997-1000.

Takarangi, MKT, Oulton, JM, Green, DM, \& Strange, D. (2016). Boundary restriction for negative emotional images is an example of memory amplification. Clinical Psychological Science, 4, 82-95. 
Takarangi, MKT, Polaschek, DLL, Hignett, AJ, \& Garry, M. (2008). Chronic and temporary aggression causes hostile false memories for ambiguous information. Applied Cognitive Psychology, 22, 39-49.

Takarangi, MKT, Strange, D, \& Lindsay, DS. (2014). Self-report may underestimate trauma intrusions. Consciousness \& Cognition, 27, 297-305.

Tiggemann, M, \& Kemps, E. (2005). The phenomenology of food cravings: The role of mental imagery. Appetite, 45, 305-313.

Tiggemann, M, \& Pickering, AS. (1996). The role of television in adolescent women's body dissatisfaction and drive for thinness. International Journal of Eating Disorders, 20, 199-203.

Tiggemann, M, \& Slater, A. (2013). NetGirls: The Internet, Facebook and body image concerns in adolescent girls. International Journal of Eating Disorders, 46, 630-633.

Tiggemann, M, \& Slater, A. (2014). NetTweens: The Internet and body image concerns in pre-teenage girls. Journal of Early Adolescence, 34, 606-620.

To end food craving, try creative visual expression. (2013, July 31). Retrieved from http://www. cravemate.com/to-end-food-craving-try-creative-visual-expression.

Wade, TD, Byrne, S, \& Bryant-Waugh, R. (2008). The eating disorder examination: Norms and construct validity with young and middle adolescent girls. International Journal of Eating Disorders, 41, 551-558.

Wade, TD, Hansell, NK, Crosby, RD, Bryant-Waugh, R, Treasure, J, Nixon, R ... \& Martin, NG. (2013). A study of changes in genetic and environmental influences on weight and shape concern across adolescence. Journal of Abnormal Psychology, 122, 119-130.

Wade, TD, \& O'Shea, A. (2015). DSM-5 Unspecified feeding and eating disorders in adolescents: What do they look like and are they clinically significant? International Journal of Eating Disorders, 48, 367-374.

Want to boost your memory and mood? (2013, May 16). The conversation. Retrieved from https://theconversation.com/want-to-boost-your-memory-and-mood-take-a-nap-butkeep-it-short-13108.

Wenzel, M, \& Okimoto, TG. (2010). How acts of forgiveness restore a sense of justice: Addressing status/power and value concerns raised by transgressions. European Journal of Social Psychology, 40, 401-417.

Wenzel, M, \& Okimoto, TG. (2012). The varying meaning of forgiveness: Relationship closeness as a moderator of forgiveness effects on feelings of justice. European Journal of Social Psychology, 42, 420-431.

Wenzel, M, \& Okimoto, TG. (2014). On the relationship between justice and forgiveness: Are all forms of justice made equal? British Journal of Social Psychology, 53, 463-483.

Wenzel, M, \& Okimoto, TG. (2015). 'We forgive': A group's act of forgiveness and its restorative effects on members' feelings of justice and sentiments towards the offender group. Group Processes \& Intergroup Relations, 18, 655-675.

Wenzel, M, Okimoto, TG, Feather, NT, \& Platow, MJ. (2008). Retributive and restorative justice. Law and Human Behavior, 32, 375-389.

Wenzel, M, Okimoto, TG, Hornsey, MJ, Lawrence-Wood, E, \& Coughlin, A-M. (2016). The mandate of the collective: Apology representativeness determines perceived sincerity and forgiveness in intergroup contexts. Manuscript submitted for publication. 
Wenzel, M, Woodyatt, L, \& Hedrick, K. (2012). No genuine self-forgiveness without accepting responsibility: Value reaffirmation as a key to maintaining positive self-regard. European Journal of Social Psychology, 42, 617-627.

Wilksch, SM, \& Wade, TD. (2009). An investigation of temperament endophenotype candidates for early emergence of the core cognitive component of eating disorders. Psychological Medicine, 39, 811-822.

Wilksch, S, \& Wade, TD. (2010). Risk factors for clinically significant importance of shape and weight in adolescent females. Journal of Abnormal Psychology, 119, 206-215.

Woodyatt, L, \& Wenzel, M. (2013a). The psychological immune response in the face of transgressions: Pseudo self-forgiveness and threat to belonging. Journal of Experimental Social Psychology, 49, 951-958. DOI: 10.1016/j.jesp.2013.05.016.

Woodyatt, L, \& Wenzel, M. (2013b). Self-forgiveness and restoration of an offender following an interpersonal transgression. Journal of Social and Clinical Psychology, 32, 225-259.

Woodyatt, L, \& Wenzel, M. (2014). A needs-based perspective on self-forgiveness: Addressing threat to moral identity as a means of encouraging interpersonal and intrapersonal restoration. Journal of Experimental Social Psychology, 50, 125-135. DOI: 10.1016/j. jesp.2013.09.012

Worthington, EL. (2006). Forgiveness and reconciliation: Theory and application. New York: Routledge. 


\section{The history of psychology at the University of South Australia: From little things big things grow}

Jacques Metzer

Part 1: The birth and development of the School of Psychology (1994-2005)

The birth of the School of Psychology at the University of South Australia on 1 January 1994 was the formal result of some four years of intensive political efforts by a small group of highly dedicated academic individuals. Lobbying to establish a home for psychology commenced even before the agreement to merge two precursor higher education institutions - the South Australian Institute of Technology [SAIT] and some campuses of the South Australian College of Advanced Education [SACAE] - was signed and then ratified by the State Parliament to create the University of South Australia Act 1990 (SA). The university commenced on 1 January 1991.

\section{Background}

Prior to 1989, although a number of psychology-educated lecturing staff had been working, teaching students and researching in the precursor institutions, the main problem was that psychology was regarded as a 'captive' discipline. It existed in these institutions only to 'service' other professions, such as social work, teaching, business, communication, physiotherapy and other health science professions. As a consequence, many lecturers interested in advancing knowledge in the discipline found their academic, teaching and research activities stifled and even prevented by the 
requirements of the institutions' academic units, which were often multidisciplinary and professional schools. Much of the time, there were non-psychology academics who determined what areas of psychology should be considered and taught, assessed and researched, all justified ostensibly by the requirements of whatever professions were taught by that school.

There were two exceptions to this. First, at the Magill and Salisbury campuses of SACAE, over the years there had developed two psychology 'majors' within undergraduate degrees in teaching, communication and liberal studies, primarily through the efforts of psychology academics Colin Parsons, Russell Hawkins, Gary Childs and several others - although neither of these majors had ever been eligible for accreditation by the Australian Psychological Society [APS]. In 1994, these majors were to become the basis for the new School of Psychology's accredited sequence in a 'named' undergraduate psychology degree.

Second, at the City campus of SAIT, through co-operation between the then South Australian Psychological Board and SAIT to reduce pressure on the $4+2$ pathway to registration, I had designed a fifth-year Graduate Diploma of Social Science (Psychological Practice), to launch Australia's first version of the $5+1$ pathway to registration in South Australia [SA]. This course was offered from the then School of Social Studies at SAIT in which a number of psychology staff were employed, and I became its first course director in 1989, and taught in the course together with Greg Ireland, Biruta Dietz and Richard (Dick) Sladden. It was accredited by the Australian Psychological Society and proved to be very popular, lasting for about ten years. Decades later, fifth-year professional psychology courses were introduced in other Australian states without acknowledgment of the precedent SA had already set. This experience taught us yet again of the difficulty of gaining recognition elsewhere in Australia for innovation originating in South Australia.

Nevertheless, it was from these humble beginnings that a new School of Psychology in the new university was envisioned.

\section{Political issues in the lobbying for the formation of the new school}

A cross-campus lobbying group of psychology academics in the two precursor institutions was created early in 1990, and I was elected as chair. It was quickly established that there were fifty-five academics with psychology qualifications, most of whom were engaged in captive discipline lecturing and service delivery to non-psychology degrees. Late in 1990, after councils of the two institutions agreed to merge these institutions, a cross-campus meeting of all psychology-interested academics approved the formation of a steering group to lobby for the creation of a school of psychology.

Meanwhile, new schools, faculties and their dean positions were being established. A major stumbling block appeared when the University Schools and Faculties 
Implementation Committee attempted to refuse the application by the psychology steering committee on the grounds that only schools which produced professional qualifications would be accepted — not schools that were solely discipline-oriented. It did not take very long for the psychology steering committee to attack the credibility of that decision by producing evidence that psychology is both a discipline and a profession with statutory requirements. Part of that evidence was produced by the forwarding of a then newly released publication by the then Commonwealth Department of Employment, Education and Training [DEET], which confirmed that psychology was at the top of a long list of professions that would require massive growth of practitioners by 2000 (Department of Education, Employment and Training [DEET], 1994). The existence of both the Psychological Practices Act 1973 (SA) (which was revised in 1976 and repealed in 2010) in South Australia and the Psychological Registration Board in SA sealed the fate of this argument.

The psychology steering group lobbied hard for joining one of two possible faculties: Social Science and Health Science. Strong opposition was posed by elements of the social science faculty, including the then dean, and a number of academics from the then School of Social Studies at SAIT. However, when the faculty was restructured to include humanities, that opposition effectively disappeared with the appointment of a new dean. The Faculty of Health Science displayed support, but was slow in its procedures to approve the proposed school. The then deputy vice-chancellor believed that psychology was a social science discipline, and that was where the new School of Psychology was finally positioned. But this was effectively against the wishes solicited formally by the deputy vice-chancellor from all staff wanting to join the school. Only one senior psychology academic, who then did not join the new school, had expressed the wish to join the Faculty of Humanities and Social Science, versus the other twenty-five academics who preferred the Faculty of Health Science. It was now May 1993 and the committed band who had pressed for a school from the beginning in 1990 were tiring of the lobbying and repeated submission efforts, but were very close to achieving the goal. Hence, the group agreed to join the Faculty of Humanities and Social Science. Out of those twenty-five academics who commenced in the school in 1994, only two persons remain in a formal capacity to this day (in 2016): Cathy Balfour as lecturer and I myself, as an adjunct associate professor/volunteer.

Even though I led the push for the school, my specific thanks for the exceptional efforts to support the coming-into-existence of the new school must go to the following academics and colleagues (with their 1993 titles):

- Dr Philip Mohr, for his exceptional strategic advice and persistence in the face of opposition

- Greg Ireland, for his excellent carrying of the role of chair of the steering committee during my absence on study leave overseas during part of 1992 
- Richard Sladden, for his invaluable advice and assistance in harnessing support in the profession for the creation of the school

- Associate Professor Ralph Hood, for his knowledge of the many internal processes and his connections in the institutions and for his sense of humour during dark and euphoric times alike

- Dr Michael Rowan, chair of the Faculty of Social Science Board, for his invaluable assistance in the preparation of the final submission to the Academic Board and then the university council to create a school of psychology

- Dr Maureen Nimon, chair of various university-wide restructuring committees, for her encouragement and for ensuring that the required submitted paperwork was in order

- Monette Garcia, who initially bore the brunt of preparing all documentation pertaining to the submissions, and then led the general staff team as it grew to fourteen personnel in 2005

- the many academic and professional colleagues inside and outside the university who wrote supporting documentation or who professed support for the creation of a school of psychology. In the latter category, I want to mention particularly the assistance of Margaret Chandler and Associate Professor Keith Macconochie, who were members of the early steering committee, but chose to stay in their respective schools, and also Richard (Dick) Sladden, who joined the school later and undertook the unenviable task of writing the documentation for the new Master of Clinical Psychology and the new Master of Organisational Psychology. He became the first course director of both degrees.

To illustrate the difficulty of the task to create this school and the strength of opposition to it, a remark made a year or so later in reminiscence by Dr Nimon still comes to my mind: 'One of the miracles in the university is the School of Psychology' (personal conversation, 1994).

\section{The commencement of the new School of Psychology}

The school was born into a new Faculty of Humanities and Social Science and it commenced operations on three campuses of the university's six: the city campus, Magill and Salisbury. Psychology staff and undergraduate teaching at the Salisbury campus were fairly quickly relocated to mainly Magill in order to teach the new APS-accredited degrees of Bachelor of Arts (Psychology), and the Bachelor of Arts (Psychology) Honours. The City campus was the home for the already APS-accredited fifth-year Graduate Diploma of Psychological Practice, which soon extended to an APS-accredited, two-year Master of Psychological Practice. 
The school commenced with an existing complement of twenty-five academic staff, eight with $\mathrm{PhDs}$ and ten with masters' degrees as their highest degrees. The staff were myself, as the head of school; Professor AJH (Jim) Gaite; Associate Professor Ralph Hood; five senior lecturers; and seventeen lecturers.

The school maintained at the City campus a suite of non-APS-accredited Graduate Diplomas of Counselling at fourth year, and later added a Masters of Counselling degree and a Professional Doctorate of Counselling, all non-APS-accredited, but very popular with students, both in Australia and later — with the exception of the DCouns — in two overseas locations.

Effectively, when it commenced, the school had a ready-made complement of staff, although there was a dearth of professors, particularly when one realises that the only full professor, Jim Gaite, had been in college/university management and had not published in psychology for many years. Associate Professor Ralph Hood was an effective counselling practitioner/lecturer but also had not published very much. But both brought to the new school a wealth of experience in university administration and management and a knowledge of academic organisation. It was clear that building academic seniority in psychology in the new school was an early priority.

The other related deficiency identified early was the sparseness of (thematic) research in psychology, because previously there had been little chance of acquiring resources, little incentive for staff research in psychology and insufficient building of research groupings in psychology. Hence, the school set about in the mid-1990s to rectify these problems, while maintaining the strengths already built in professional and applied psychology.

\section{Existing research in the new school}

It was not that the academic staff of the school had been idle in conducting research: many, though not all, staff were actively engaged in research collaboration with staff from other schools within the university in multidisciplinary research; others were carrying out research by themselves; and yet others were collaborating in psychological research with members of other universities. Emphasis in the new university was very much on applied and professional research and less on single-disciplinary research. Illustrating this emphasis is the following list of topics in which psychology academics were engaged at the time (compiled in 1994):

\section{Social psychology, including:}

- $\quad$ hierarchy formation in juries and other task groups

- legal judgements: effect of personal characteristics on perceived culpability

- $\quad$ social influence and nonverbal behaviour 
- $\quad$ status generalisation and social influence

- $\quad$ attitudes to nuclear disarmament and world-mindedness

- $\quad$ ethology, personality and cultural factors of hand movements

- $\quad$ self-concept and disability

- $\quad$ peer group aggression at school

- $\quad$ AIDSawarenessamong peopleofnon-English-speaking background [NESB] ${ }^{7}$

- evaluation of the national AIDS campaign

- division of labour in families

Occupational and organisational psychology, including:

- human factors and ergonomics

- $\quad$ pilot and instructor training

- $\quad$ computer-aided tomography [CAT]: flight simulation and flying skills

- $\quad$ selection criteria for pilots

- $\quad$ stress management in pilots

- $\quad$ retirement planning for women

- $\quad$ adjustment on return to work

- hormonal substrates of human stress responses

Learning, including:

- learning theory and behaviour modification

- $\quad$ student learning strategies

- remediation of learning difficulties in neurologically impaired children

- re-inforcement schedules

- analysis of response topography

- behavioural correlates of reinforcement

Clinical psychology, including:

- $\quad$ treatment of pain

- hypnosis

- $\quad$ sexuality

- $\quad$ cognitive deficits and rehabilitation following brain injury

7 This is today called a culturally and linguistically diverse [CALD] background. 
- depression treatment

- $\quad$ shyness in men

- $\quad$ psychological assessment and evaluation

- $\quad$ substance abuse

- counselling

\section{Recruitment and employment of professorial staff}

As a first strategic move, the services of Tony Winefield as a research professor were engaged in 1995, albeit in a 0.2 FTE position, while he maintained his associate professorship at the University of Adelaide. His credentials in research and other accomplishments (listed more fully in Chapter Eight) were even then without equal, and he used this position to stimulate a number of areas of research in the school, particularly in psychological factors in work stress, unemployment and research methodology.

Second, mainly through my efforts to develop forensic psychology as a strength area of the school, a five-year contract was signed in 1997 with the SA Government through the Department for Correctional Services [DCS] for the funding in the school of a professorial position in forensic psychology and two lecturer positions, in return for the development of forensic psychology research and supplying a continuing forensic psychology service to the DCS, in particular to prisoners in South Australian gaols. Kevin Howells was appointed to the professorship and proceeded to lead and develop correctional/rehabilitation forensic psychology, securing many research grants and drawing in a number of staff and $\mathrm{PhD}$ students. The school also appointed new staff, including Dr Andy Day, who himself later achieved a professorial position at Deakin University. Appointed to the two lecturer positions were Mitch Byrne and Stuart Byrne, the latter being replaced later by Quentin Black. They added to the forensic psychology profile of the school.

Third, the school was asked to include the Sleep Centre, which had previously been based at the University of Adelaide and the Queen Elizabeth Hospital [TQEH]. This centre was headed by Dr Drew Dawson, who became employed at UniSA as associate professor, and later achieved promotion to professor. Over the years, the centre attracted significant research funding, and a number of students graduated from it with PhDs, some of whom achieved academic positions in Australian universities.

Fourth, the School of Psychology was granted a foundation chair by the university in 1999, to which was appointed Professor Tony Winefield, who remains in that position to this day of writing (in 2016). 


\section{Developing research in the school}

Research concentrations flourished in the school with the appointment of the professoriate.

1998 saw the formation of the Forensic and Applied Psychology Research Group, headed by Professor Kevin Howells. This was a development of the existing Applied Psychology Research Group, which earlier had been initiated and headed by Dr Phil Mohr. The Work and Stress Group was headed by the newly appointed Dr Maureen Dollard, who had transferred from her position in 2000 at the Whyalla campus, where psychology remained a captive discipline. In 2003, the two groups merged to form a new centre, the Centre for Applied Psychological Research [CAPR] — an acronym that was rather more appropriate than the alternative, had the centre been named the Centre for Research in Applied Psychology! Tony Winefield was the first director of the CAPR from 2003-06, followed by Maureen Dollard, who was promoted to professor soon afterwards. At this time, the Sleep Centre remained a separate entity, and left the school for several years to operate independently of any school in the faculty, which itself had been expanded into a division.

Seniority in leading clinical research was a continuing problem and repeated attempts to appoint a professor of clinical psychology were unsuccessful, yet the postgraduate clinical teaching programs (masters and professional doctorate) were taking in large numbers of students.

The new Psychology Clinic commenced in 1997. Its first director, Charles Karathanasis, had been an important initiator in securing many external student placements in the face of hostile elements in the state government Mental Health Service and other services, which had 'disallowed' UniSA students access to professional clinical placements, in favour of the existing arrangements for Flinders University and University of Adelaide student clinical psychology placements. Karathanasis effectively bypassed the system and created our own network of qualified external supervisors. The other two universities soon recognised the problem with having two parallel systems of supervisor allocation, and so the three psychology schools then took matters into their own hands in distributing allocations. The second director of the clinic was Stuart Byrne, who secured further external placements and commenced some research activities from within the clinic; he also secured external funding for various servicing programs to external agencies, such as the DCS, and came close to breaking even the clinic's budget.

The Psychology Clinic at the City East campus was officially opened in 1997 by the vice-chancellor and dedicated to the memory of the first lecturer in clinical psychology at the City East campus, Biruta Dietz, an expert in the treatment of depression, who died suddenly and prematurely in 1996. A large portrait of her was unveiled by the vice-chancellor and was displayed for many years in the clinic at City 
East (see Figure 7.2). It was not until later that the seniority deficiency in clinical psychology was resolved.

\section{Research graduates of the school from inception to 2006}

Once the university commenced, it became possible for the first time to offer doctorate degrees. The school took advantage of this to upskill a number of its staff by enrolment in $\mathrm{PhDs}$, and also to encourage enrolment in $\mathrm{PhDs}$ by the best of the first cohort of graduating honours students in psychology. In addition, I designed a four-year degree Doctor of Psychology, on the degree certificate of which only one of three specialisations was recorded - Clinical, Forensic or Organisational. This was offered from the midto late 1990s. This degree was only the second in Australia after Murdoch University's Professional Doctorate in Psychology. There was an attempt to achieve American Psychological Association [APA] accreditation, after gaining APS accreditation and respective colleges' approval, but this was unsuccessful, largely because an external internship of at least one year could not be guaranteed by the university, and the APA did not want to award accreditation outside of the US.

\section{More innovation: A six-year master's degree in psychology}

Commensurate with innovation in the new school during the late 1990s, it was suggested by both Phil Mohr and Greg Ireland (and then enacted by me in its design and subsequent passage through the university and accreditation by the APS) that a six-year master's in psychology be introduced with competitive entry direct from secondary school after Year 12. In some ways this would have similarities with the 'Oxbridge' model. The degree packaged into one bundle the existing psychology degrees of three years of undergraduate study, one year of honours and two years of study at master's level. Passage through the university academic approval systems was surprisingly easy and supported by all committees and boards, although successful accreditation by the APS proved to be more difficult initially.

The degree proved to be extremely popular and had the immediate effect of raising substantially the Tertiary Entrance Rank [TER] into the undergraduate psychology degree from the mid-70s to mid-90s. Before this six-year psychology qualification degree, which was another first in Australia for psychology, students had needed to apply and compete for entry to fourth year and then again for fifth and sixth year. Once accepted into the UniSA six-year degree, students needed to meet only specific hurdles at the end of third and fourth year to progress, and had the option of leaving before the end with an exit Bachelor degree or an exit Bachelor (Honours) degree. However, developing exigencies and a change of leadership in the school resulted in this degree being done away with before it fully lived up to its potential of providing a simple and single pathway to registration with a specialisation. 


\section{Success of the postgraduate coursework degrees in counselling}

The school inherited a rich tradition of two postgraduate diplomas in counselling (one in health and one in education), with a number of staff qualified to teach and practise counselling. Ralph Hood and Ilona Reid led the very committed teaching team. One of the earliest developments was to design and offer an eighteen-month Master of Social Science (Counselling) degree followed later by a three-year Doctor of Counselling degree, which was designed by John Court, who had joined the school after 2000. Although none of these degrees were APS-accredited, they were accredited by the Psychotherapy and Counselling Federation of Australia [PACFA]. These degrees were immensely popular and took in large numbers of graduates from psychology and related disciplines' undergraduate degrees.

From the late 1990s, the university encouraged schools to offer degrees in a number of Asian countries and to promote entry to foreign students to their onshore offerings. The School of Psychology's counselling degrees were very successful. Both Hong Kong and Singapore were targeted, since the university had academic partners there. As a result, huge numbers of students enrolled offshore; large monetary profits were made for the school and university; staff became experienced travelling academics and had some additional income; and student satisfaction questionnaires were overwhelmingly positive. The one real negative was that there were no resources with such large student numbers to offer them external placements, although onshore students in the master's program had the option to do an internal placement within the clinic. However, eventually, the lack of suitable compulsory counselling placements proved to be the undoing of much of this success, as university quality assurance processes demanded more of these degrees; offshore partners wanted to include compulsory placements; and the faculty demanded more of the profits.

In addition to the above, I had laid the foundations with Hong Kong Baptist University, the Asia Pacific Management Institute in Singapore and the HELP University College in Kuala Lumpur to commence the UniSA Bachelor of Psychology degree offshore, as well as to offer an articulated pathway into the degree at UniSA in Adelaide. While the latter had commenced by 2005, leadership change at the school and vice-chancellor levels meant that the former were never enacted.

In the late 2000s, all the counselling courses along with the Doctor of Psychology and the forensic psychology master's degree were discontinued through the recommendations of an external reviewer, and the school embarked upon different directions with eventually an almost complete turnover of academic staff. All this meant that it was time for me to reconsider my place in the revised-look school. 


\section{References}

Department of Education, Employment and Training [DEET]. (1994, June). DEET job futures. Australia: Commonwealth government.

\section{Legislation}

Psychological Practices Act 1973 (SA). Retrieved from https://www.legislation.sa.gov.au/LZ/ C/A/PSYCHOLOGICAL\%20PRACTICES\%20ACT\%201973/2010.06.30/1974.37. UN.PDF.

University of South Australia Act 1990 (SA). Retrieved from https://legislation.sa.gov.au/LZ/ C/A/UNIVERSITY\%20OF\%20SOUTH\%20AUSTRALIA\%20ACT\%201990.aspx. 



\title{
The history of psychology at the University of South Australia: Recent history
}

\author{
Kurt Lushington
}

Part 2: Recent history (2005-16)

To complement this chapter, academic staff working in the school in 2015 were invited to write about themselves, their highlights and their experiences. This additional material can be located at the School of Psychology's website. ${ }^{8}$

Overview 2005-16

The decade since 2005 has seen large changes to the UniSA School of Psychology. This includes its leadership, research focus, degree offerings and personnel. Of all these changes, the most notable has been the merger of the School of Psychology with the School of Social Work and Social Policy. Another major influence on the life of the school over this time has been the change in vice-chancellors, with the consequent impact on school priorities and activities. ${ }^{9}$

In common with contemporaries at other schools in the country, the school has seen the transition from traditional to digitally informed teaching practices (with more change in the wings); the reduction in postgraduate offerings (resulting in a

8 See http://www.unisa.edu.au/Education-Arts-and-Social-Sciences/Psychology-Social-Workand-Social-Policy/About-the-school.

9 In order, the vice-chancellors have been Professors Denise Bradley (1997-2007), Peter Høy (2007-12) and David Lloyd (since 2012). 
singular focus on clinical psychology); the move to a demand-driven education system and less restrictive entry requirements (with psychology accounting for an especially high proportion of these new students); the introduction of Federal Government oversight of clinical registration and program accreditation (with a rise in the cost of accreditation and greater complexity in governance); the introduction of the Australian Quality Framework and the subsequent regulation of degree structures and curriculum standards; an increased focus on research performance (with a greater reliance on external benchmarking, such as the Excellence in Research Australia [ERA] scheme); the expectation of greater individual accountability, leading to the increased formalisation of academic work practices; pressure to increase international student numbers, partly to globalise the student body but also to generate revenue; and, finally, an increased pressure on productivity against a background of shrinking resources. Much of the school's activities over the last decade have been in response to these broader influences.

Over and above the broader external influences, local factors have also influenced the school. The regional teaching units at Whyalla and Mount Gambier have been incorporated into the school, resulting in a greater emphasis on regional engagement. There has been the slow but welcome consolidation of psychology staff from around the university onto one campus at Magill. The earlier decision to withdraw from the Magill campus has been reversed and the site is now proposed as an education precinct involving the collocation of a primary and high school alongside the schools of psychology and education. The last decade has seen the university change its position on transnational teaching, which has been characterised by a cycle of engagement, disengagement and then re-engagement. More recently, there has been a freeing-up of academic roles and the opportunity to employ academic staff on teaching-only positions. This has led to a greater diversity of roles and also the consideration of new career pathways. Finally, there has been a greater emphasis within the university on promoting the work-readiness of undergraduate students, which in the case of the school has led to greater industry engagement, industry placements and curriculum changes to improve graduate employability.

The school has also been part of the university's broader journey from an amalgam of teacher colleges and institutes to a modern and diverse institution. In 2016, the university will be twenty-five years old, and a lot has been achieved in that time. A number of league tables have emerged in the last few years which purportedly rank university performance. The current preference at the University of South Australia is for the QS World University Rankings. According to the 2015 QS World University Rankings, the University of South Australia was ranked 288 out of the top 300 universities in the world and one of only two Australian institutions aged under twenty-five to feature in the top 300. Notably, it is now ranked twenty-fifth out of universities aged under fifty years. This is quite an achievement for a young university 
founded in 1991. Just as impressive has been the rise in the ranking of the discipline of psychology, which in 2016 was ranked by the QS World University Rankings as $150^{\text {th }}$ in the world - a notable achievement for a small school. The school has also climbed steadily in the ERA rankings, with a maximum score in 2015 of 5 (well above world standard), placing it in the company of only six other institutions in the country.

\section{Leadership and governance}

The history of the school's leadership over the past decade has been complicated. It has encompassed several acting appointments, leadership change as the consequence of a merger with another school, and appointments with limited tenure. In 2005, the school leadership passed from Associate Professor Jacque Metzer to Dr Kurt Lushington. As one of his first acts, Dr Kurt Lushington appointed three new staff to fill vacancies in the undergraduate team at Magill campus: Drs Janet Bryan, Jill Dorrian and Michelle Tuckey. This was a deliberate effort to invigorate the school and ensure momentum. The three staff have since made considerable contributions to the school. Dr Bryan brought with her expertise in cognitive psychology and nutrition, Dr Tuckey expertise in organisational psychology and Dr Dorrian expertise in sleep research and psychophysiological psychology.

Dr Kurt Lushington was acting head of school until May 2006, when Professor Bernard Guerin was appointed as head of school. In 2006 Dr Lushington was promoted to Associate Professor and in 2007 was re-appointed as the acting head of school. He remained in that role until 2009, when, as part of a university-wide restructure of schools, the School of Psychology was merged with the School of Social Work and Social Policy to form the School of Psychology, Social Work and Social Policy [PSW] and his position was disestablished. Thus psychology as a 'school' ceased at that time and the history of the 'School of Psychology' since 2009 can be better reframed as the history of the 'Discipline of Psychology'.

The merger was not simply in name; it was also a physical merger, with the City East campus staff moving to Magill campus. The Psychology Clinic was also rehoused, moving from the basement of the Playford building on the City East campus into the former gatehouse of Murray House, located on the grounds of the Magill campus. Thus, while not contiguous and while apart from staff in the Centre for Sleep Research, the majority of staff were now for the first time all located on one campus. The previous split with postgraduate psychology at the City East campus and undergraduate psychology at the Magill campus was thus obviated, helping build a more cohesive school culture.

In 2009 the former head of the School of Social Work and Social Policy, Associate Professor Adrian Vicary, was appointed head of school, and Associate Professor Kurt Lushington was appointed deputy head and discipline leader of psychology. After 
Associate Professor Adrian Vicary's retirement in 2012, the head of school position was filled by Associate Professor Kurt Lushington who was also promoted to a full professor at that time. Apart from a lengthy interregnum from June 2014 to June 2015, Professor Kurt Lushington has remained in that role and is the current head. During the latter interregnum, Lushington was variously on extended leave but for much of that period was the acting pro vice-chancellor for the Division of Education, Arts and Social Sciences. Acting in his role while on leave were Associate Professor Lia Bryant (social work) who was acting head of school from June to December 2014 and Associate Professor Janet Bryan (psychology), from January to June 2015.

Professor Kurt Lushington's appointment in 2012 also saw the introduction of associate head of school positions: one for teaching and learning, and one for research and research education. These positions mirror the governance structure created at the same time within the university and the appointment of divisional deans of teaching and, likewise, research. The two associate head positions, together with those of the head of school and school manager, have since comprised the school executive. The associate head of school research position was held by Associate Professor Sarah Wendt (social work) in 2012-13 and by Associate Professor Lia Bryant in 2014-15. The associate head of school teaching and learning position was continuously held by Associate Professor Janet Bryan (psychology) from 2012 until her retirement in 2015.

As a result of associate heads either taking sabbatical leave or being seconded to the head of school role, others within the school have also taken on acting roles. Associate Professor Jill Dorrian (psychology) was the acting associate head of research mid- to late 2013 and again mid- to late 2015, and Associate Professor Michelle Tuckey (psychology) was acting associate head of school (teaching and learning) from late 2014 to mid-2015. Notably, and in order to maintain the balance of representation between disciplines and to ensure senior representation for accreditation purposes, the associate head of school appointments have been typically drawn from both the disciplines of psychology and social work/social policy — that is, one from each discipline.

A noticeable feature of the last decade has been the growth in the number of professional staff within the university. They now undertake increasingly complex roles, leading to the appointment of staff with increasingly higher levels of expertise. This trend has also been evident at the school level and has led to the creation of several senior positions, exemplified by the creation of the school manager position. This position has proven pivotal to the successful running of the school, requiring financial, business and administrative, and personnel management skills. In 2008, Ms Julie Wong-Ogisi was seconded from the School of Social Work and Social Policy to manage the School of Psychology and facilitate the school merger. Ms Wong-Ogisi was subsequently the school manager of the merged school until her departure to work overseas in 2013, when her position was filled by the current incumbent, Ms Ornella Wood. 


\section{Program offerings}

The last decade has seen a big change in teaching practice and offerings. In the former case, teaching practice has come to accommodate digital technology, as exemplified by online delivery, blended learning, Massive Open Online Courses [MOOCs], and learning analytics. In the latter case, a notable feature has been the progressive reduction in both the number of programs and the number of courses offered within programs. The trend toward fewer degrees with fewer electives has had its positives and negatives. On the positive side, the consolidation of teaching has meant that more time has been available for research. On the negative side, it has meant the loss of subspecialties and boutique courses in academics' individual areas of expertise.

The explanation for the trend in the reduction in program offerings is complex. Arguably, the consolidation can partly be attributed to the reduction in Federal funding and the consequent pressures on academic productivity and the capacity of schools to service programs. An additional factor affecting the servicing of programs has been the capacity of the school to meet the requirements of the Australian Psychology Accreditation Council (responsible for the professional accreditation of psychology degrees). The requirement for accreditation is that undergraduate psychology programs are taught with a 22:1 student-to-staff ratio, and postgraduate programs with an 8:1 ratio. At this time in the history of higher education, adhering to these ratios means that student revenue is barely sufficient to cover staff salaries. Thus the margins for financial viability are tight. The staffing requirements for accreditation, together with diminished Federal funding, has limited the capacity of psychology schools with modest student numbers (and, hence, a lower income base) to underwrite multiple degree offerings. This is the case for the school at present, and especially applies to postgraduate clinical coursework offerings, for which postgraduate student revenue typically falls far short of staffing costs and for which surplus revenue from undergraduate teaching is usually required to cover costs.

The majority of the school's degree offerings were withdrawn over the period 2008-12. Although local factors at the time also influenced events, a strong contributor to the change in the school's degree profile at this time in its history was the pressure on its budget, as discussed above. In 2008, the school withdrew its suite of coursework Doctorate of Psychology degrees in clinical, forensic and organisational psychology and also, following changes to staffing at the time, the Masters of Psychology (Forensic) and a shortlived Graduate Diploma in Jungian Psychology. In 2012, because of similar pressures on viability, the Master of Psychology (Work and Organisational) was withdrawn. Similar to the trend towards fewer postgraduate psychology programs being offered by schools generally around Australia, the only remaining program on offer by the University of South Australia in 2015 is the Master of Psychology (Clinical). 


\section{Transnational teaching}

The school was the first university to offer postgraduate training in counselling in Hong Kong and Singapore. Arguably, it has been responsible for the establishment of counselling education in both these countries. As such, its legacy has been immeasurable. Under the leadership of Professor Jim Gaites, it started its first offering in Hong Kong in 1998. This was the Masters in Social Science (Counselling) (54 units, 1.5 years full time), undertaken in partnership with Hong Kong Baptist University. The first course ever taught in Hong Kong was Research in Counselling, delivered by Professor Kurt Lushington, who, for medical reasons, stepped in for Professor Gaites. In 2000, under the leadership of Professor Ralph Hood, the program was also started in Singapore. This was in partnership with the Asia Pacific Management Centre and, after their takeover in 2000, with Kaplan University. Following the death of Professor Gaites in 2000, the Hong Kong and Singapore programs were variously led by Associate Professor Ralph Hood, Ms Ilona Reid and Mr Greg Ireland. The onshore suite of counselling programs were taught and managed by Ms Melanie Parry-Jones.

The entry of the school into the transnational teaching space in 1998 can be viewed as part of a more general trend at that time among Australian universities to set up programs in Asia. In contradistinction, however, to most other institutions, where the trend was to focus on business and engineering degrees, the school's focus on providing an applied social sciences program was unique. Despite critics, the counselling option proved to be very successful; indeed, within a few years it attracted stiff local and Australian competition. The offshore program was taught as intensives by Adelaide staff, who would fly in for what was often a very busy week. Student demand was such that at its peak the school was running three program intakes a year in Hong Kong and two in Singapore, with a total intake of about 300 students per year.

The counselling programs delivered offshore complemented a nested suite of programs delivered in Adelaide. These included the Graduate Diploma in Counselling (36 units), Masters in Social Sciences (Counselling) (54 units), and Doctorate of Counselling (108 units). The local programs were taught by the staff teaching in Hong Kong and Singapore, and the annual intakes were approximately thirty and fifty students per year into the diploma and master's programs, respectively. The doctoral program, which commenced in 2002 and was led by Dr John Court, was unique in Australia and for its time acquired a renowned reputation.

In 2005, the senior management group of the university decided to withdraw from transnational teaching. This decision had a profound impact on the financial underpinnings of the school. The subsequent withdrawal of offshore revenue led to a budget shortfall within the school. This deficit combined with the influence of an unfavourable program review, which questioned the viability of the school's programs. Both of these things were arguably triggers for the 'managing change process' 
undertaken in 2007 to address the school's problems. The outcome of this process was staff redundancies, with the loss of almost half of the school's staff. The majority of these staff taught in the counselling programs, with only Dr Nadine Pelling and Professor Kurt Lushington remaining in 2015 from the original team of ten. An immediate effect of the process was the closure of the counselling programs. The last counselling courses were taught both locally and offshore in 2008. Of the suite of counselling programs, the counselling doctorate had a very limited lifespan, with just three intakes of around ten students per round. As a corollary, the withdrawal from transnational teaching, staff reductions and loss of income also contributed to the 2008 decision to withdraw the doctoral and master's degrees in forensic and work and organisational psychology.

However, under the direction of Vice-Chancellor David Lloyd, the university re-engaged with offshore teaching in 2013. At that time, the Hong Kong Baptist University was seeking a partner to provide a top-up degree for their diploma and associate degree in psychology. With this opportunity in mind, the school resumed its partnership with Hong Kong Baptist University, with the goal of delivering its Bachelor of Psychological Science degree to Hong Kong students. The accreditation of the program in Hong Kong was led by Dr Elissa Pearson, who has continued to be responsible for program delivery and oversight of transnational teaching. The first intake of students occurred in 2015. Unlike previous transnational teaching arrangements, the current psychology program was designed to be taught by Hong Kong staff, with Adelaide staff involvement limited to exam moderation, preparation of teaching material, consultation and teaching of intensives in three specialist courses. This model is hoped to address one of the limitations of the previous transnational teaching model — namely, the dissipation of academic time and energy away from research as a consequence of frequent travel and teaching without breaks.

\section{Indigenous psychology, work-readiness and psychology education}

Post-2008, the school has paid particular focus to its undergraduate curriculum. Among other curriculum changes, this has resulted in a greater attention to Indigenous psychology and to furthering the work-readiness of students.

The development of curriculum material for teaching Indigenous psychology was led by Dr Robert Ranzijn. Dr Robert Ranzijn and Mr Keith McConnochie were awarded Office of Teaching and Learning grants to undertake work researching and developing material on cultural competence and Australian Indigenous content in undergraduate psychology. This work was presented to universities around Australia.

In order to enhance student employability, and in recognition that the majority of undergraduate psychology students did not proceed to clinical or higher degree training, the school has followed three broad strategies. The first strategy has been to 
develop pathways for students into programs that lead to professional qualifications. The second strategy has been to build work-readiness into the undergraduate curriculum. The third strategy has been to introduce practical training into the undergraduate curriculum relevant to the demands faced by graduates in employment - primarily, training in interpersonal skills. The development of new pathways for undergraduate psychology students into professional training programs has been led by Ms Cathy Balfour. Ms Balfour, with colleagues in allied disciplines, has helped establish double degrees in human resources and human services (and a pending double degree in human movement). The double degree psychology and human services program has proven to be particularly effective, with a graduate employment rate of almost 100 per cent.

The school has received national and international attention for its effort in promoting work-readiness training in the curriculum. In recognition of its efforts, the school received from the Commonwealth Government's Office of Learning and Teaching the prestigious 'Citations for Outstanding Contributions to Student Learning' in 2013 'for introducing work-integrated learning and enhancing student experiences and professional development into psychology undergraduate degrees through nationally-recognised curriculum renewal'. ${ }^{10}$ This was awarded to the Psychology Teaching and Learning Team: Dr Janet Bryan, Dr Michelle Tuckey, Dr Rob Ranzijn, Dr Renae Hayward, Dr Elissa Pearson, Mrs Cathy Balfour and Professor Kurt Lushington. To improve work-readiness, the team introduced a first-year course on building a professional identity to prepare students for a career in psychology, followed by a capstone course in third year, where students undertook a work placement (recently increased to 150 hours). This has occurred under the leadership of Ms Cathy Balfour (program director), Associate Professor Michelle Tuckey (course co-ordinator) and Ms Sarah-Jane Branford (placement officer). The student placements include primary and high schools, aged care homes, local councils, a variety of NGOs, rehabilitation providers, volunteer organisations, and human resource providers. The student placements have received very positive feedback from the industry and have proven to be very effective at improving not only the work-readiness of students but also graduate employment chances.

Finally, in addition to the other strategies, the school has invested in a suite of counselling courses to enhance the interpersonal skills of students and thereby improve employability. This has been under the leadership of Drs Nadine Pelling and Amanda Hutchinson. Students undertaking the counselling courses not only acquire interpersonal skills but also meet the minimum requirements for membership of the Australian Counselling Association. This has also resulted in the introduction of a

10 For more information, see http://www.unisa.edu.au/Education-Arts-and-SocialSciences/Teaching-Excellence/Teaching-Excellence-News-Archive/Staff-acknowledged-forOutstanding-Contributions-to-Student-Learning. 
specialisation within the undergraduate program offerings - that is, the Bachelor of Psychological Sciences (Counselling and Interpersonal Skills).

\section{Research}

In the past decade, the school has made a concerted effort to raise the quality of its research outputs. A successful strategy has been to prioritise the recruitment of staff with strong research profiles rather than recruiting to fill gaps in teaching. A further strategy has been to build strong research centres to support staff and students. In addition, the broader strategy within the university towards program consolidation and fewer electives has resulted in freeing up academic time for research. A further successful strategy has been the appointment of an acting head of school to support research and staff development. Finally, the establishment of a strong and experienced team of professional staff dedicated to researcher support has been of great assistance. This team is led by Ms Mirela Garaplija and assisted by Ms Pam Hart, Sharron Skelly and Shiller Peirawan.

A key driver of research within the school since its foundation has been the Centre for Applied Psychological Research [CAPR], established in 2003 with Professor Tony Winefield as its foundation director. Since 2006, Professor Maureen Dollard has been the director. The centre has had various constituencies in the last decade including forensic, counselling and organisational psychology. Mirroring the changes in staff, the centre has refined its focus in recent years to work, health and organisational psychology. From 2009, the centre developed a vision of 'worker health for all in the Asia Pacific'.

In 2010, Professor Maureen Dollard and Associate Professor Michelle Tuckey convened a meeting in Darwin of experts in psychosocial factors. At this meeting, experts from the Asia Pacific region agreed that a much greater co-operative effort was needed in the Asia Pacific region, in order to build a stronger evidence base to address the issues and contribute to global knowledge development, as well as policies and practice in the region. This initiative led to convening annual expert meetings throughout the Asia Pacific region, in Johar Bahru, Tokyo, Bangkok, Adelaide, Seoul and Shanghai. A major outcome of this international collaboration has been the development of the Asia Pacific Academy for Psychosocial Factors at Work in 2012, and a Memorandum of Understanding with the European Academy for Occupational Healthy Psychology for co-operative research.

In line with these developments, the vice-chancellor announced in 2014 a new research centre, the Asia Pacific Centre for Work Health and Safety [APC-WHS], which was to supersede the Centre for Applied Psychological Research. The centre was designated by the WHO as a Collaborating Centre in Occupational Health in 2015, and contributes to the WHO Global Health work plan. Dr Phil Kavanagh joined 
the centre in 2012, and has expertise in clinical, social and personality psychology. Dr Silvia Pignata teaches in aviation and is the former program director of the postgraduate Occupational Health and Safety Management and Human Factors programs. Associate Professor Harry Savelsberg and Dr Helena de Anstiss are also members of the APC-WHS. The work of the centre is supported by research fellow Dr Valerie O'Keeffe, research associate Dr Sarven McLinton, research assistants Tessa Bailey, Harry Becher, David Duong, Annabelle Neall, Rachael Potter, Mikaela Owen, Wes McTernan and Amy Zadow, and many PhD candidates.

The centre also has several international adjuncts - Professor Christian Dormann, University of Mainz; Professor Jan de Jonge, Eindhoven University of Technology; Associate Professor Akihito Shimazu, Tokyo University; and Dr Awang Idris, University of Malaya. Over the past five years, the centre board was chaired by Ms Kathryn McEwen. The centre and its affiliates have established themselves as leading researchers and champions of workplace safety, with international renown and an enviable history of grant and publication successes and success at hosting international conferences.

Another major driver of research in the school has been the Centre for Sleep Research. This centre was established by Professor Drew Dawson in 1994 and was located at the Queen Elizabeth Hospital until 2005, when it was transferred to the City East campus. At its inception, the centre was initially under school governance, but due to differing priorities it became effectively a divisional rather than a school-based unit. In 2008, it formally came under the governance of the school. In 2012, the centre leadership were made an offer by Central Queensland, which the University of South Australia did not match - namely, the promise of continuing positions to assure the continuity of key staff. This led to the majority of centre staff decamping to new premises on Greenhill Road in Goodwood (at The Appleton Institute). As the majority of $\mathrm{PhD}$ students were close to completing their candidature, however, most remained with the University of South Australia.

Associate Professor Jill Dorrian and Drs Mark Kohler and Siobhan Banks stepped up to deal with the vacuum left by former centre staff, and the subsequent successful rebuilding of the centre can be attributed to their efforts. They were further assisted by Dr Michelle Short, who was recruited in 2012 to take over a commissioned research project from the Bushfire Centre for Research Excellence, examining sleep and performance in bushfire fighters. In 2014, the eminent sleep researcher Professor Mary Carskadon was appointed as centre director, sharing her time between Browns University Rhode Island and Adelaide. The centre has also been ably supported by Professor Bill Runciman and his patient safety group. Professor Runciman, another eminent researcher and practitioner, brought with him expertise in patient safety, a field in which he leads Australia. As part of a realignment of research activities, Professor Runciman has since joined the Centre for Population Health at the University of 
South Australia. Staff and students from the Centre for Sleep Research have continued to dominate the Australian Sleep Association awards and grants, and to further its international reputation. A new centre on the Magill campus is envisioned to be completed in the near future, which will finally allow all the psychology staff to be located on one campus.

A third force of research activity within the psychology arm of the school has been the clinical team, including Professor David Gleaves and Drs Amanda Hutchinson, Susan Simpson, Phil Kavanagh, Nadine Pelling and Helen Stallman. Professor Gleaves, formerly of Christchurch University New Zealand, was recruited as the clinical professor, and brought with him expertise in taxonomical research and eating disorders. He has also been a senior editor for several prestigious and highly ranked psychology journals. Dr Susan Simpson was recruited as clinic director, and brought with her expertise in schema therapy and telepsychology, the latter building on her experience in setting up a service in Scotland. Dr Simpson has continued to be active in promoting telepsychology, establishing a training unit to deliver clinical services to Port Augusta, completing several evaluation projects, and hosting two national conferences on telepsychology at the university.

Meanwhile, Dr Kavanagh was recruited from Central Queensland University, and brought with him expertise in personality and evolutionary psychology. He led the clinical program from his appointment in 2011 until the appointment of professor David Gleaves in 2012. Dr Nadine Pelling has brought her expertise in counselling psychology to the team and innovations in counselling teaching methodologies. Dr Amanda Hutchinson was a recent appointment recruited from the Flinders Medical Centre, and has brought her expertise in cancer research. Dr Helen Stallman was recruited from Queensland University of Technology, and has brought with her expertise in the mental health of young adults. A further member of the team was Dr Lisa Chantler, who shared her time between clinical supervisor in the clinic and private practice. Dr Chantler brought with her expertise in forensic psychology. Overall, a high percentage of the psychology staff are clinical psychologists with research $\mathrm{PhDs}$. This combination has been a preference when appointing staff with the goal of promoting translational research and clinical treatments.

In recognition of the increasing emphasis on cognitive neuroscience within psychology, the school launched a new program, the Bachelor of Psychological Science (Cognitive Neuroscience). In addition, it established a new research laboratory to support teaching and research — the Cognitive Neuroscience Laboratory. The program development was led by Drs Hannah Keage, Owen Churches and Mark Kohler, producing arguably the first dedicated cognitive neuroscience degree in Australia. The appointment of Professors Ina Bornkessel-Schlesewsky and Matthias Schlesewsky from Germany, and Dr Tobias Loetcher from Flinders University, has since consolidated the laboratory staffing. Professors Bornkessel-Schlesewsky and Schlesewsky, both eminent 
researchers with international reputations, have brought with them expertise in the neuropsychology of language and brain processing. Dr Loetcher has brought with him expertise in the neuropsychology of spatial processing. Dr Hannah Keage was recruited from the University of Cambridge, and has brought with her expertise in the cognitive neuroscience of ageing and dementia. Dr Mark Kohler (who also has a foot in the sleep camp) was recruited from the Women's and Children's Hospital in Adelaide in 2010, and in addition to his expertise in sleep research has brought with him expertise in the neuropsychology of learning and memory. The Cognitive Neuroscience Laboratory has also been ably assisted by Drs Scott Coussens (laboratory co-ordinator) and Phillip Alday (postdoctoral fellow and instructor).

The school is one of only a handful of institutions worldwide to conduct research at the interface between sleep and cognitive neuroscience. In addition, it is also one of the only laboratories in Australia to systematically study higher-order language processing in the brain (that is, how the brain processes language in more natural contexts such as sentences and texts, rather than single words). The cognitive neuroscience group plan on expanding this research focus to include Indigenous languages of Australia and the Pacific and under the leadership of Drs Hannah Keage and Tobias Loetscher to form an additional centre focusing on aging and impairment neuroscience.

\section{Excellence in Research Australia [ERA]}

The school has achieved considerable success in raising its research performance. This is perhaps best illustrated by its ERA ratings, which have risen from a low of 2 (below world standard) in 2006, to 4 (above world standard) in 2010, to the maximum possible of 5 (well above world standard) in 2015. This rise can be attributed to the appointment of high-performing research staff; vibrant research centres and centre leadership; the streamlining of program offerings so that staff can balance the demands of teaching and research; and a school culture that generally celebrates and values research success.

\section{The future}

The University of South Australia and the School of Psychology, Social Work and Social Policy are now firmly established in the higher education firmament. The next decade will be about deepening the school's research expertise in cognitive neuroscience; sleep; work, health and safety; conservation psychology; and clinical therapies. It will be about developing further the work-readiness of psychology undergraduate students, with the goal of establishing the Bachelor of Psychology degree as a professional endpoint in its own right. Finally, it will be about how best to combine teaching, research, professional leadership and community engagement so that the school is best placed address the big social issues of our day. 
This book is available as a free fully-searchable ebook from www.adelaide.edu.au/press

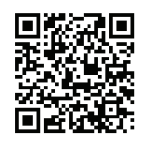

